UNIVERSIDADE DE SÃO PAULO

FACULDADE DE FILOSOFIA, LETRAS E CIÊNCIAS HUMANAS DEPARTAMENTO DE LINGÜÍSTICA:

PROGRAMA DE PÓS-GRADUAÇÃO EM SEMIÓTICA E LINGÜÍSTICA GERAL

SUELI MARIA RAMOS DA SILVA

O discurso de divulgação religiosa materializado por meio de diferentes gêneros: dois ethé, duas construções do Céu e da Terra 


\section{UNIVERSIDADE DE SÃO PAULO \\ FACULDADE DE FILOSOFIA, LETRAS E CIÊNCIAS HUMANAS DEPARTAMENTO DE LINGÜÍSTICA: PROGRAMA DE PÓS-GRADUAÇÃO EM SEMIÓTICA E LINGÜÍSTICA GERAL}

SUELI MARIA RAMOS DA SILVA

\section{O discurso de divulgação religiosa materializado por meio de diferentes gêneros: dois ethé, duas construções do Céu e da Terra}

Dissertação apresentada ao Programa de Pós-Graduação em Semiótica e Lingüística Geral do Departamento de Lingüística da Universidade de São Paulo, para obtenção do título de Mestre em Lingüística.

Área de Concentração: Semiótica e Lingüística Geral

Orientador: Profa.Dra.Norma Discini de Campos

São Paulo 
AUTORIZO A REPRODUÇÃO E DIVULGAÇÃO TOTAL OU PARCIAL DESTE TRABALHO, POR QUALQUER MEIO CONVENCIONAL OU ELETRÔNICO, PARA FINS DE ESTUDO E PESQUISA, DESDE QUE CITADA A FONTE.

Catalogação na Publicação

Serviço de Documentação do Sistema Integrado de Bibliotecas - SIBI

Faculdade de Filosofia, Letras e Ciências Humanas

RAMOS-SILVA, Sueli Maria.

O discurso de "divulgação religiosa" materializado por meio de diferentes gêneros: dois ethé, duas construções do Céu e da Terra / Sueli Maria Ramos da Silva; orientador Norma Discini de Campos - São Paulo, 2007.

$360 f$.

Dissertação (Mestrado - Programa de Pós-Graduação em Semiótica e Lingüística Geral. Área de Concentração: Semiótica e Lingüística Geral) - Faculdade de Filosofia, Letras e Ciências Humanas.

1. Semiótica 2. Análise do Discurso 3. Lingüística 4. Estilística I. Título. 


\title{
O discurso de divulgação religiosa materializado por meio de diferentes gêneros: dois ethé, duas construções do Céu e da Terra
}

\author{
Dissertação apresentada ao Programa de Pós-Graduação em Semiótica \\ e Lingüística Geral do Departamento de Lingüística da Universidade \\ de São Paulo, para obtenção do título de Mestre em Lingüística. \\ Área de Concentração: Semiótica e Lingüística Geral
}

Aprovado em: 20 / agosto / 2007

BANCA EXAMINADORA

Profa.Dra. Norma Discini de Campos

Instituição: FFLCH - USP

Presidente

Profa. Dra. Diana Luz Pessoa de Barros

Instituição: FFLCH - USP

Titular

Profa.Dra. Lúcia Teixeira de Siqueira e Oliveira

Instituição: UFF - Externo

Titular 
À Norma Discini, mestra singularíssima, por me ensinar a semiotizar a vida.

Ao Rafael, meu eterno companheiro e incentivador pelas paixões eufóricas da benquerença.

Aos meus pais, Maria e José, e ao meu irmão, Samuel, pela euforia e apoio constantes pelos quais acompanharam minha trajetória semiótica. 


\section{AGRADECIMENTOS}

À Profa. Dra. Norma Discini de Campos, pela sua extraordinária competência, atenção, apoio e acompanhamento criterioso durante todo o processo de orientação.

Aos Profs. Drs. Ivã Carlos Lopes e Diana Luz Pessoa de Barros, pelos preciosos apontamentos apresentados no exame de qualificação.

Aos Profs. Drs. de Graduação e Pós-graduação do Departamento de Lingüística da Universidade de São Paulo, por terem sedimentado as bases sólidas necessárias à realização deste trabalho.

Aos funcionários do Departamento de Lingüística, Érica, Robson e Ben Hur, pela presteza no atendimento aos alunos.

Ao Rafael Minussi, pela revisão cuidadosa deste trabalho e pelas valiosas sugestões apresentadas.

Aos amigos e colegas do Programa de Pós Graduação em Semiótica e Lingüística Geral, pelo apoio e incentivo.

Ao meu tio Isaías (in memorian) pelas reflexões que inspiraram a realização deste trabalho.

À Coordenação de Aperfeiçoamento de Pessoal de Nível Superior (CAPES) pela concessão da bolsa de mestrado e pelo apoio financeiro necessário à realização desta pesquisa. 
"Nenhum fato, coisa ou gesto, entretanto, é encontrado já com as marcas do sagrado. $\mathrm{O}$ sagrado não é uma eficácia inerente às coisas. Ao contrário, coisas e gestos se tornam religiosos quando os homens os batizam como tais. A religião nasce com o poder que os homens têm de dar nomes às coisas, fazendo uma discriminação entre as coisas de importância secundária e as coisas nas quais seu destino, sua vida e sua morte se dependuram. Esta é a razão por que, fazendo uma abstração dos sentimentos e experiências pessoais que acompanham o encontro com o sagrado, a religião se nos apresenta como um tipo de fala, um discurso, uma rede de símbolos. Com esses símbolos os homens discriminam objetos, tempos e espaços, construindo com seu auxílio, uma abóbada sagrada com que recobrem seu mundo". 


\section{RESUMO}

RAMOS-SILVA, Sueli Maria. O Discurso de divulgação religiosa materializado por meio de diferentes gêneros: dois ethé, duas construções do Céu e da Terra. 2007. 360 f. Dissertação (Mestrado) - Faculdade de Filosofia, Letras e Ciências Humanas, Universidade de São Paulo, São Paulo, 2007.

Nosso fazer sancionador, responsável pelo recorte e delimitação de totalidades, estabeleceu, dentro do campo discursivo religioso, subconjuntos de formações discursivas, que correspondem ao espaço discursivo de divulgação religiosa de duas totalidades, supostamente confrontantes: Catolicismo e Testemunha de Jeová. Tomamos, portanto, um corpus doutrinário, de ensino e instrução religiosa, voltado tanto ao público adulto, quanto ao infanto-juvenil.

A fundamentação teórica a ser utilizada, para que seja possível nos adequar aos objetivos do estudo proposto, consiste das bases teóricas da Semiótica greimasiana, de linha francesa, da Análise do discurso (AD) francesa, herdada pela Semiótica por meio dos conceitos elaborados por Maingueneau (1996, 1997, 2005a, 2005b), da filosofia da linguagem, dos princípios do dialogismo bakhtiniano e das noções de heterogeneidade, estabelecidas por Authier-Revuz (1982, 1990).

Ao observar as recorrências dos mecanismos de construção do sentido dos textos, refletiremos sobre a noção de discurso de divulgação religiosa que permeia o espaço discursivo das totalidades em confronto, e que é pertinente à cena enunciativa partilhada em que se propõe um fazer-crer peculiar à Palavra Revelada.

Tendo por princípio que a apreensão do sentido dos textos não é algo exterior e apriorístico ao signo, mas resultante da reunião dos dois planos compreendidos pela 
linguagem, o plano da expressão e o plano do conteúdo, e levando em consideração julgamentos de valor e atitudes expressos pela sociedade e concretizados nos discursos, buscar-se-á, no recorte analítico proposto, analisar semioticamente como a fé, contemplada por meio do discurso de duas instituições religiosas, propicia a construção de dois ethé, segundo duas construções do Céu e da Terra. Cada texto de divulgação religiosa (unus), visto como materialização de um gênero (catecismo e publicação de estudo bíblico), permitirá que seja depreendido o éthos das totalidades recortadas, A (Igreja Católica) e B (Testemunha de Jeová), na medida em que cada totalidade atende às próprias restrições de uma semântica global. Dentro dos objetivos de examinar os mecanismos de construção do sentido em textos de divulgação religiosa, propomos considerar como e por que podemos depreender dois modos diferentes e conflitantes de presença no mundo, o estilo (éthos e antiéthos) de duas cenas enunciativas contrastantes entre si, a partir de textos que materializam o espaço discursivo de divulgação religiosa.

Palavras-Chave: Divulgação religiosa; Catolicismo; Testemunha de Jeová; éthos, antiéthos. 
RAMOS-SILVA, Sueli Maria. The religious divulgation discourse materialized by two different genres: two ethé, two confrontations of Heavens and Earth. 2007. $360 \mathrm{f}$. Dissertation (Master Degree in Linguistics). Faculdade de Filosofia, Letras e Ciências Humanas, Universidade de São Paulo, São Paulo, 2007.

\begin{abstract}
Our sanction doing, responsible for the delimitation of totalities, established, in the religious discursive field, discursive formation subgroups which correspond to the religious divulgation discursive space of two totalities supposedly confronting: Catholicism and Jeovah's witnesses. Though, we have got a teaching and religious instruction doctrinaire corpus created not only to the adult public, but also to the young one.

To achieve our objectives, the theoretical basis used consists on Greimas's Semiotics concepts, French Discourse Analysis, incorporated in Semiotics by Maingueneau (1996, 1997, 2005a, 2005b), philosophy of language, Bakhtin's dialogism principles and heterogeneity notions established by Authier-Revuz $(1982,1990)$.

The observation of the recurrences of the meaning construction mechanisms of the texts will permit us to reflect on the notion of religious divulgation discourse which permeates the discursive space of the totalities in confrontation and pertinent to the shared enunciative scene where it is proposed a particular believing doing to the Revealed Word.

Having as principles that the apprehension of the meaning of the texts is neither exterior nor aprioristic to the sign, but resulting from the union of the two plans included in language, the expression plan and the content plan, and taking into consideration value judgments and attitudes expressed by society and concretized in the discourses, we will exam semiotically how the faith, presented by the discourse of two religious institutions, propitiates
\end{abstract}


the construction of two ethé according to two constructions of Heavens and Earth. Each religious divulgation text (unus) considered as the materialization of a genre (catechism and biblical study publication) will permit to deduced the ethos of the totality A (Catholic Church) and B (Jeovah's witnesses), in so far as each totality respects the constraints of a global semantics. Among the objectives of examining the construction meaning mechanisms in religious divulgation texts, we propose to consider how and why we can deduce two different and controversial ways of presence in the world, the style (ethos) and (antiethos) of two confronting enunciative scenes from texts which materialize the religious divulgation discursive space.

Keywords: Religious divulgation, catholicism, Jeovah's witneses, ethos, antiethos. 


\section{SUMÁRIO}

Introdução.

1. Pressupostos teóricos e metodológicos: noções básicas que respaldam as análises.

Capítulo I - Breve histórico sobre as Religiões Cristãs, com recorte prioritário para o Catolicismo e a Testemunha de Jeová.

Capítulo II - Análise de textos de divulgação religiosa: enunciatário infanto-juvenil.

1. Catecismo infanto-juvenil (Católico): $O$ Primeiro Catecismo da doutrina Cristã. 67

1.1 "Jesus nos Faz seus Soldados": Análise Semiótica. 79

1.2 Manifestação: A cenografia considerada como uma unidade sincrética.

2. Publicação de estudo bíblico infanto-juvenil (Testemunha de Jeová): Meu Livro de Histórias Bíblicas. 136

2.1 "Davi e Golias": análise semiótica. 150

2.2. Manifestação: A cenografia considerada como uma unidade sincrética. 169

Capítulo III - Análise de textos de divulgação religiosa: enunciatário adulto 179

1. Compêndio do Catecismo da Igreja Católica. 179

1.1 "Segunda seção: Os Sete Sacramentos da Igreja": análise semiótica 195

1.2 A Iconografia Cristã como Percepção Sacralizada: Análise do Tríptico dos Sete Sacramentos de Rogier Van Der Weyden. 219 
2. Brochura de divulgação religiosa (Testemunha de Jeová): O Que Deus Requer de Nós? 240

2.1. Lição 11 - “Crenças e costumes que desagradam a Deus": análise semiótica.....259

Capítulo IV - Dissensão religiosa: O espaço discursivo de divulgação religiosa na delimitação do estilo de totalidades antagônicas: A (Católica) e B (Testemunha de Jeová)..285

1. Discurso religioso fundador e discurso de divulgação religiosa. 288

1.1 Discurso religioso .289

1.2 Discurso religioso fundador. 295

1.3 Discurso de divulgação religiosa 302

2. O páthos dado como confronto de paixões. 310

3. Éthos e antiéthos na divulgação da fé 313

Conclusão 321

Referências Bibliográficas 327

Anexos 339

Anexo A...... 340

Anexo B 343

Anexo C 345

Anexo D 359 


\section{INTRODUÇÃO}

"No princípio, Deus criou o céu e a terra. Ora, a terra estava vazia e vaga, as trevas cobriam o abismo, e um sopro de Deus agitava a superfície das águas. Deus disse: Haja luz e houve luz".

Gênesis $1: 1-4^{1}$.

A crença, tal como presente no Dicionário de Semiótica de autoria de Greimas e Courtés (s.d, p. 91-92), entendida "enquanto adesão do sujeito ao enunciado de um estado", apresentada "como um ato cognitivo, sobrederminado pela categoria modal da certeza", presente também em diversas instâncias discursivas e não apenas como fundamento da fé religiosa, seria, segundo o autor, um tema recorrente às pesquisas semióticas "dos anos vindouros".

Porém, no que concerne ao estabelecimento da crença como fundamento da fé religiosa, recorte que buscamos estabelecer para a realização da presente pesquisa, no que diz respeito aos trabalhos no âmbito da semiótica e da Análise do Discurso (AD), que já teriam versado sobre esse tema, podemos observar uma escassez considerável de estudos a esse respeito no Brasil, destacando-se apenas no âmbito francês as análises realizadas pelo Centro para análise do discurso religioso de Lyon (CADIR).

Podemos ressaltar, dentre os trabalhos que utilizamos como base para a elaboração da presente pesquisa, as análises realizadas por Delorme e Geoltrain (1982); Discini (2005a); Fiorin (1988); Maingueneau (2005a); Orlandi (1996); Panier (1986); bem como as análises feitas pelos periódicos da Revista trimestral Semiotique et Bible publicados sob a direção do Centro para análise do discurso religioso de Lyon.

O que se tem na maioria dos estudos sobre a crença como fundamento da fé religiosa é a abordagem dessa questão pautada unicamente por um viés sociológico, tal como se pode notar nos trabalhos de Bourdieu (1974), entre outros.

\footnotetext{
${ }^{1}$ BÍBLIA de Jerusalém. São Paulo: Paulus, 2004. p.33.
} 
A escassez de trabalhos a esse respeito, somada à curiosidade e interesse que o fenômeno religioso nos desperta, foi determinante para a escolha desse corpus de pesquisa.

A determinação do corpus de pesquisa referente a esta dissertação, dadas às singularidades do discurso religioso contemplado, nos permitiu a construção do termo discurso de divulgação religiosa como categoria de análise.

Dessa maneira, a investigação dos mecanismos de construção do sentido em textos de divulgação religiosa pode contribuir para:

a) $\quad \mathrm{O}$ entendimento da cena fundadora, tida como a verdade revelada discursivamente, a Bíblia Sagrada.

b) A elucidação da relação estabelecida entre o discurso religioso fundador e o discurso correspondente à divulgação religiosa (catecismo, brochura de estudo bíblico, livro instrucional, etc.) como cenas enunciativas complementares.

A fundamentação teórica a ser utilizada, para que seja possível nos adequar aos objetivos da análise proposta, consiste dos fundamentos tomados da semiótica greimasiana de linha francesa, da Análise do discurso $(\mathrm{AD})$ francesa incorporada à semiótica por meio dos conceitos elaborados por Maingueneau (1996, 1997, 2005a, 2005b), da filosofia da linguagem, dos princípios do dialogismo bakhtiniano e das noções de heterogeneidade, estabelecidas por Authier-Revuz (1982, 1990), em seu desenvolvimento dos princípios bakhtinianos.

Propomos analisar semioticamente diferentes mecanismos de construção do sentido, segundo os quais se concretiza a "interincompreensão constitutiva" como "primado do interdiscurso" (cf. MAINGUENEAU, 2005a). 
A noção de "interincompreensão constitutiva" será considerada, tal como postula Maingueneau (cf. 1997), como a relação estabelecida entre duas formações discursivas em um processo de "tradução generalizada", correlacionada a uma "interincompreensão". A interincompreensão é determinada pelo fato de que uma formação discursiva faz penetrar o "outro" em seu próprio interior. Entretanto, essa tradução é determinada pelo próprio sistema de restrições semânticas do discurso-agente, considerado como o "tradutor" do discurso paciente ("traduzido"). Esse processo de tradução repousa em dois conjuntos de semas: os positivos (reivindicados) e os negativos (rejeitados). Dessa forma, a tradução do "outro" pelo discurso agente constitui uma espécie de simulacro, um engodo necessário. O discurso primeiro (discurso-agente), tendo como objetivo mascarar a sua invulnerabilidade, projeta as categorias semânticas desse "outro" dentro do registro negativo de seu próprio sistema.

Retomamos, também de Maingueneau (cf. 2005a), as noções de universo discursivo, campo discursivo e espaço discursivo.

Segundo Maingueneau (cf. 2005a), a noção de universo discursivo é de pouca utilidade ao analista, por compreender todo o conjunto de formações discursivas que interagem numa conjuntura dada. O campo discursivo remete ao conjunto de formações discursivas pelas quais se constitui um discurso (campo político, religioso, filosófico, etc.). O espaço discursivo refere-se aos subconjuntos de formações discursivas que as hipóteses do analista julgam relevante colocar em relação. Discursos antagônicos de duas totalidades postas em confronto geram o espaço discursivo.

Isolamos para essa pesquisa o campo discursivo religioso. Dentro do campo do discurso religioso, delimitamos como espaço discursivo enunciados de divulgação religiosa de duas totalidades religiosas (Católica e Testemunha de Jeová) e que, supostamente, se opõe entre si. Veremos, portanto, como cada uma das formações discursivas, das quais julgamos 
relevante estabelecer a oposição, supõe estar em conformidade com uma "Palavra Divina Absoluta”.

Nosso fazer sancionador, responsável pelo recorte e delimitação de totalidades, estabeleceu como recorte textual prioritário textos que materializam gêneros de divulgação religiosa (catecismos, livros instrucionais e brochuras de estudo bíblico) das duas totalidades religiosas consideradas em confronto e voltadas, cada qual, tanto ao público adulto, quanto ao infanto-juvenil. Tomamos como base, portanto, um corpus doutrinário, voltado ao ensino e instrução religiosa.

Assim, buscamos analisar o modo pelos quais as instituições religiosas cotejadas, apesar de materializar em seus textos instrucionais o espaço discursivo de divulgação religiosa e de apresentar o éthos correspondente a essa tipologia de discurso, caracterizam duas totalidades distintas, a da Testemunha de Jeová e a da Igreja Católica, dois ethé, a partir da escolha da mesma tipologia de discurso. Buscamos observar como e por que a imagem de quem diz, obtida pelo modo de dizer, ao refletir diferentes modos de presença no mundo, pode contribuir para o entendimento de ideais e aspirações ditados socialmente.

Partindo do princípio de que o significado não é exterior e apriorístico ao signo, o estilo ou o éthos de cada uma dessas totalidades A (Catolicismo) e B (Testemunha de Jeová) será descrito, a partir da análise dos enunciados divulgadores das Sagradas Escrituras, a fim de se delinear o modo próprio de ver e perceber o mundo do sujeito, inscrito na formação discursiva determinada e depreensível dos próprios textos.

Desse modo, buscar-se-á, no recorte analítico proposto, analisar semioticamente como a fé contemplada por meio de duas instituições religiosas propicia a construção de dois ethé como duas construções do Céu e da Terra. 
Depreenderemos, assim, o modo recorrente de dizer que remete ao modo recorrente de ser e perceber do sujeito linguageiro inscrito no mundo, e que corresponde ao éthos das totalidades consideradas.

Por sua vez, definiremos o estilo como efeito de individuação do discurso, produto das relações entre o plano do conteúdo e o plano da expressão dos textos. Definiremos o estilo como éthos, tom, voz, caráter e corporalidade do discurso considerado, a que também remeteremos ao páthos, como imagem do enunciatário, feixe de expectativas instituídas pelo espaço discursivo de divulgação religiosa e pelas totalidades A (Católica) e B (Testemunha de Jeová).

Assim sendo, sem a pretensão de esgotar o assunto, devido aos propósitos e limitações de uma pesquisa em âmbito de mestrado, na medida em que estudos sobre o discurso religioso de base bíblica são escassos, e geralmente, tendem a se restringir à vertente católica, faz-se necessária, como contribuição ao desenvolvimento de pesquisas de análise do discurso religioso de base bíblica, uma proposta dessa natureza, pautada pelo cotejo de duas instituições religiosas e por meio da associação de duas vertentes de análise, a de uma teoria do discurso de preocupação ideológica $(\mathrm{AD})$ e da Semiótica.

Os objetivos centrais desse trabalho são:

a) A partir das análises dos enunciados de divulgação religiosa contemplados, e ao observar as recorrências dos mecanismos de construção do sentido dos enunciados enfeixados pelo discurso religioso fundador e pelo discurso de divulgação religiosa, procuraremos apresentar as peculiaridades que distinguem esses dois discursos, tidos como cenas enunciativas complementares. 
b) Examinar os mecanismos de construção do sentido segundo os quais se concretiza a "interincompreensão constitutiva" do discurso como "primado do interdiscurso", no que diz respeito a textos que materializam o espaço discursivo de divulgação religiosa (catecismo, compêndio, livro instrucional, brochura de estudo bíblico, etc.) de duas totalidades postas em confronto.

c) Entender o confronto entre diferentes construções de mundo, via discursos opostos, confrontados no ato da análise.

d) Depreender o éthos correspondente a cada totalidade discursiva examinada: Catolicismo e Testemunha de Jeová.

e) Observar o sujeito da percepção, o observador não apenas como o sujeito cognitivo que se emparelha ao narrador do nível discursivo, mas o observador que apreende o mundo segundo um ritmo e que, ao imprimir um ritmo a seus discursos, contribui para a fundamentação do éthos.

f) Depreender o páthos, como imagem do enunciatário, feixe de expectativas instituídas pela totalidade dos gêneros de divulgação religiosa e pelas totalidades A (Católica) e B (Testemunha de Jeová).

Dentro dos objetivos de examinar mecanismos de construção do sentido, podemos considerar como e por que podemos depreender dois modos diferentes e conflitantes de presença no mundo, dois estilos que remetem a dois modos de ser, dos quais depreendem-se 
dois ethé, como duas diferentes imagens do sujeito enunciador bipartido no discurso de profissão de fé.

Determinaremos assim, o estilo não mais dos gêneros de divulgação religiosa, mas o estilo de duas cenas enunciativas contrastantes entre si, a partir de textos que materializam o espaço discursivo de divulgação religiosa.

Dessa maneira, ao tomarmos o "espaço discursivo como uma rede de interação semântica", "um processo de interincompreensão generalizada" (MAINGUENEAU, 2005a, p. 103), podemos postular a intersecção entre esses dois discursos, em que o "eu" encontra-se inserido no "outro", já que o discurso segundo, o discurso da totalidade discursiva das Testemunhas de Jeová, só existe mediante a existência do discurso primeiro (Catolicismo), construindo-se por meio de sua descontinuidade, ambos em referência ao mesmo discurso fundador (A Palavra Revelada) como argumento de autoridade.

Desse modo, amparados nos fundamentos teóricos anteriormente mencionados, sem de forma alguma buscar estabelecer um discurso de apologia a quaisquer das religiões em pauta, propomos analisar ao longo de toda dissertação o modo pelo qual o discurso religioso se posiciona ao apresentar o relato bíblico tido como seu discurso fundador.

Buscamos demonstrar, por meio da construção do sentido pela diferença, como o discurso bíblico se modifica de religião para religião com base na ideologia que as fundamenta, na medida em que, ao analisarmos discursos de divulgação religiosa, torna-se indissociável tratarmos linguagem e ideologia, por ser a própria criação divina dada de forma linguageira. 


\section{Pressupostos teóricos e metodológicos: noções básicas que respaldam as análises}

Dentro dos objetivos de exame dos mecanismos de construção do sentido das unidades consideradas para análise, os quais supõem a escolha das categorias de totus e unus como metodologia analítica de uma totalidade, estabelecemos como ponto de partida o conceito de totalidade, tal como se apresenta em Greimas e Courtés (1986, p. 465):

Considerada como integrante da articulação semântica geral da quantidade, a totalidade pode ser tratada seja como uma categoria que se articula, segundo V. Brøndal, nos dois termos contrários que são o integral (totus) e o universal (omnis), seja como subarticulação do primeiro desses termos que pode ser formulado como o termo complexo que permite apreender a totalidade dos dois aspectos ao mesmo tempo: como grandeza discreta, distinta de tudo aquilo que ela não é (unus) e como grandeza inteira, apreendida em sua indivisibilidade (totus). Entretanto, é preciso reconhecer que a reflexão semântica sobre os universais quantitativos necessita ainda ser aprofundada (GREIMAS; COURTÉS, 1986, p. 465).

Ainda no que concerne ao âmbito da totalidade, podemos nos remeter ao estudo desenvolvido por Discini (2004b), que demonstra o movimento do totus em direção ao unus como metodologia analítica de uma totalidade.

O unus pressupõe o totus, "o bloco inteiro", a totalidade integral, a qual "destaca a absorção dos indivíduos isolados numa massa indivisível". Estilo é, então, totalidade, enquanto unidade integral (unus) e enquanto totalidade integral (totus), sendo que um termo pressupõe o outro, numa relação de interdependência. (DISCINI, 2004b, p. 34)

Segundo Discini (2004b), compete ao analista determinar qual é o unus, o recorte final, a unidade integral considerada para análise. A totalidade integral, por sua vez, estará sempre e pressupostamente implícita à unidade integral. A propósito, acrescentamos que essa relação entre totus e unus Discini (2004b) incorporou de Brøndal (1986). 
Assim sendo, teremos estabelecido como recorte textual prioritário (unus) textos que materializam gêneros de divulgação religiosa (catecismos, compêndios e livros de estudo bíblico - narrativas bíblicas), das duas totalidades religiosas (totus): Catolicismo e Testemunha de Jeová, consideradas para análise.

Voltemos às unidades recortadas, para que seja possível proceder a uma introdução à problemática do gênero. Para tal fim, buscamos inicialmente apoio em Bakhtin (2003).

Conforme salienta o autor ao longo do estabelecimento da definição da problemática dos gêneros do discurso, todos os campos da atividade humana, nas suas mais diversas manifestações, ligam-se ao uso da linguagem. Por conseguinte, o emprego da língua se efetua por meio de enunciados que refletem as condições específicas de cada campo da atividade humana. Cada um dos campos de utilização elabora tipos relativamente estáveis de enunciados, denominados "gêneros discursivos", caracterizados por uma estrutura composicional, uma temática e um estilo. A temática é característica da esfera de sentido e diz respeito ao assunto de que trata o gênero. A estrutura composicional é representada por meio da estrutura apresentada pelo texto. O estilo, segundo Bakhtin (2003), refere-se às marcas lingüísticas exigidas por um determinado gênero e que o caracterizam, e mais do que isso, segundo Discini (op.cit.), o estilo se refere ao éthos do gênero: o estilo do gênero.

Carvalho (2005, p. 60) procede à definição do que consiste o estilo do gênero como a "base para a compreensão do éthos do enunciador: a imagem que constrói de si depende da imagem que constrói do outro, no contexto específico de cada interação verbal. O éthos se relaciona, dessa forma, com os simulacros que circulam na comunicação".

Assim, tomamos como fundamento as noções estabelecidas por Fiorin (2005b) e, posteriormente, desenvolvidas por Carvalho (2005) concernentes à distinção entre gênero e esferas de circulação, erroneamente tratadas como sinônimas na linguagem cotidiana. 
Fiorin (cf. 2005b), ao se valer do pensamento bakhtiniano, estabelece a definição da noção de gênero como uma organização relativamente estável caracterizada por uma temática, uma forma composicional e um estilo. Já em relação às "esferas de circulação", essas podem ser definidas, de acordo com Carvalho (cf. 2005, p. 51), como "o espaço em que circulam distintos gêneros", todos ligados a essa esfera de atividade cotidiana ou institucionalizada.

Partindo do princípio contratual, de que cada discurso escolhe o gênero que legitime sua própria cena enunciativa, podemos, com apoio em Maingueneau (2005b, p. 75), proceder à descrição dos três tipos de cena integrados pela cena da enunciação:

\begin{abstract}
A "cena de enunciação" integra de fato três cenas, que proponho chamar de "cena englobante", "cena genérica" e "cenografia". A cena englobante corresponde ao tipo de discurso; ela confere ao discurso seu estatuto pragmático: literário, religioso, filosófico... A cena genérica é a do contrato associado a um gênero, a uma "instituição discursiva": o editorial, o sermão, o guia turístico, a visita médica... Quanto à cenografia, ela não é imposta pelo gênero, ela é construída pelo próprio texto: um sermão pode ser enunciado por meio de uma cenografia professoral, profética (MAINGUENEAU, 2005b, p. 75).
\end{abstract}

Assim sendo, o "discurso religioso" se constitui como uma esfera de circulação ou “cena englobante" de acordo com a concepção de Maingueneau (2005b), na qual circulam os gêneros ("cena genérica") do espaço discursivo de divulgação religiosa.

O conceito de "modo de enunciação" se refere à "maneira de dizer" específica de um determinado texto (cf. MAINGUENEAU, 2005b, p. 94), ao qual associamos as noções bakhtinianas de "estilo", "temática" e "estrutura composicional”, já explicitados acima.

Teremos isolado, portanto, dentro do campo discursivo religioso, subconjuntos de formações discursivas, aos quais corresponde o espaço discursivo de divulgação religiosa de duas totalidades: (A) Católica e (B) Testemunha de Jeová, supostamente confrontantes. Cada unidade (unus), às quais correspondem textos de divulgação recortados para análise, será vista não apenas como materialização de um determinado gênero (catecismo, publicação de estudo 
bíblico), mais do que isso, elas serão vistas como materialização da totalidade do espaço discursivo que lhe são pressupostas: Catolicismo e Testemunha de Jeová. E dessa forma, como cada unidade (unus) pressupõe a totalidade (totus), por meio das análises das unidades, remeteremos à depreensão do estilo de cada totalidade, na medida em que cada um dos textos se relaciona com as restrições de sua própria semântica global.

Dividimos o corpus em dois blocos distintos de acordo com o enunciatário pressuposto. O perfil do leitor será depreendido dos próprios textos: as marcas discursivas é que remeterão ao diagnóstico "público infanto-juvenil" e "público adulto", já que trabalhamos com a imagem do sujeito produzida no enunciado e não apriorística a ele.

Assim, teremos estabelecido a seguinte divisão: Capítulo 2: Análise de textos de divulgação religiosa: enunciatário infanto-juvenil e Capítulo 3: Análise de textos de divulgação religiosa: enunciatário adulto. Em cada capítulo serão contemplados textos correspondentes a cada uma das totalidades: A (Católico) e B (Testemunha de Jeová).

Com relação ao capítulo 2 , pautado pela análise de textos voltados ao enunciatário infanto-juvenil, teremos recortado para a totalidade católica o seguinte texto: Lição 13: "Jesus nos faz seus soldados", extraída do catecismo infanto-juvenil: SURIAN, Frei Carmelo. Primeiro Catecismo da Doutrina Cristã. 145 ed. São Paulo: Vozes, 2005. A totalidade discursiva das Testemunhas de Jeová será cotejada mediante a utilização da história bíblica de “Davi e Golias”, extraída do MEU LIVRO de Histórias Bíblicas. São Paulo: Sociedade Torre de Vigia de Bíblias e Tratados, 1978, também voltado ao público infanto-juvenil.

No que diz respeito ao terceiro capítulo, pautado pela análise de textos voltados ao enunciatário adulto, em relação à totalidade A (Católica), teremos recortado a segunda seção da segunda parte do Compêndio do Catecismo da Igreja Católica: Os sete sacramentos da Igreja. Com relação ao discurso religioso das Testemunhas de Jeová, utilizar-se-á a lição 11 
"Crenças e Costumes que desagradam a Deus" da brochura de estudo bíblico: O que Deus Requer de Nós.

Para comprovar a hipótese de que os textos instrucionais, ao dialogar com o texto de referência, imprimem a este uma visão própria, que remete a diferentes modos de presença do sujeito, como corpus a esta análise, também utilizaremos os enunciados bíblicos aos quais os textos instrucionais fazem referência. Esses enunciados bíblicos são tidos como as fontes primeiras e fiadores desses discursos, graças ao caráter de autoridade e veracidade instituídas pela Palavra Revelada.

Consideraremos o relato bíblico em duas edições, cada qual como discurso fundador da totalidade recortada, a Bíblia de Jerusalém ${ }^{2}$, da totalidade católica, e a Tradução do Novo Mundo das Escrituras Sagradas ${ }^{3}$, da totalidade das Testemunhas de Jeová.

Partindo de tipos de textos afins, ou seja, textos instrucionais, serão observados diferentes mecanismos de construção do sentido por meio do cotejo das obras instrucionais e doutrinárias das duas totalidades religiosas recortadas para análise.

Os textos instrucionais cotejados, sendo realização parafrástica do relato bíblico, ao imitar e captar ${ }^{4}$ o texto de referência, imprimem a este uma visão própria, que remete a diferentes modos de presença do sujeito.

Para a análise dos corpora, como primeira etapa deste trabalho, estabeleceremos os pressupostos teóricos e metodológicos, com a justificativa teórica dos procedimentos de análise adotados.

Posteriormente, estabelecemos um breve histórico sobre as religiões cristãs, com recorte prioritário para o Catolicismo e a Testemunha de Jeová. Para que possamos proceder a um breve histórico das religiões consideradas, tomaremos como pressuposto o fato de que o

\footnotetext{
2 BÍBLIA de Jerusalém. São Paulo: Paulus, 2004.

3 TRADUÇÃO do Novo Mundo das Escrituras Sagradas. São Paulo: Sociedade Torre de Vigia de Bíblias e Tratados, 1995.

${ }^{4}$ As noções de imitação e captação são tomadas de Maingueneau (1997, p. 102) consituem fenômenos de heterogeneidade mostrada e serão desenvolvidos posteriormente nessa dissertação.
} 
estudo das religiões representa o compromisso com o conhecimento e não com verdades absolutas. Desse modo, propomos apresentar um breve histórico das religiões consideradas, sem de forma alguma buscar estabelecer um discurso de apologia a quaisquer das religiões em pauta, mas tão somente analisar as origens, os desenvolvimentos e as características que as singularizam como tais.

A análise semiótica das unidades recortadas será feita por meio do instrumento teórico metodológico que é o percurso gerativo do sentido, ferramenta pela qual se abstrai a construção do sentido dos textos. Procederemos à análise semiótica dos enunciados de divulgação religiosa de cada uma das unidades recortadas dos livros instrucionais e doutrinários, de ambas as instituições, cotejando-as a todo o momento com a cena fundadora.

Por fim, proceder-se-á ao exame das recorrências de ambas as visões. A recorrência de um modo único de fazer e de ser, inerente ao espaço discursivo posto em confronto, permitirá com que procuremos delinear uma organização imanente que corresponderia ao estilo dos discursos inerentes ao espaço discursivo de divulgação religiosa.

Procuraremos, portanto, lançar mão de um olhar diferenciado que estabeleça as peculiaridades que distinguem o discurso religioso fundador e o discurso de divulgação religiosa, e que entendemos como cenas enunciativas complementares. $\mathrm{O}$ discurso religioso fundador será apresentado como texto de referência dos discursos de divulgação religiosa. Veremos, portanto, como se apresentam as variações de preenchimento dos lugares enunciativos do enunciador e do enunciatário de cada um desses sujeitos na passagem da cena enunciativa do discurso religioso fundador para a cena enunciativa do discurso de divulgação religiosa.

Buscaremos estabelecer uma tentativa de definição do discurso religioso tendo por base o diálogo entre diferentes quadros teóricos, dentre os quais, utilizaremos os fundamentos sociológicos estabelecidos por Bourdieu (1974). Traremos o pensamento de Bourdieu (1974) 
para o quadro teórico da semiótica, em que o texto é analisado na relação $\mathrm{PE} / \mathrm{PC}$, na qual se busca o efeito de sentido dado como mecanismo próprio de construção do sentido do discurso religioso, observados seus desdobramentos textuais e de gêneros.

Em seguida, na tentativa de estabelecer as particularidades dos discursos de divulgação religiosa, tomaremos como ponto de partida os desenvolvimentos efetuados por Panier (1986) e Delorme e Geoltrain (1982), ambos do Centro para Análise do Discurso Religioso (C.A.D.I.R.), em Lyon. Esses desenvolvimentos foram retomados por Fiorin (1988), ao postular a noção de discurso religioso teológico ou militante, inerente a categoria de discurso religioso, responsável pela comunicação e divulgação da fé religiosa. Com base nesses pressupostos, procuraremos incorporar e expandir tais conceitos. A expansão e incorporação desses conceitos, acrescidos da análise das recorrências dos textos analisados pela ferramenta teórica do percurso gerativo do sentido, tornou possível a definição das peculiaridades do discurso de divulgação religiosa.

Também se fazem presentes as noções desenvolvidas por Maingueneau (2005a), no que diz respeito às analises desenvolvidas com relação ao discurso religioso devoto, mediante o estabelecimento do espaço discursivo por meio da oposição entre dois discursos antagônicos: o humanismo devoto e o jansenismo.

A metodologia de trabalho consistirá, portanto, do cotejo entre os textos das totalidades religiosas recortadas, de tal modo que, após a análise das recorrências diagnosticadas, seja possível descrever o estilo ou o éthos de cada uma dessas totalidades institucionalmente discursivizadas. Veremos como e por que a fé, que é contemplada em cada uma das totalidades, apesar de materializar a mesma categoria de discurso de divulgação religiosa, constitui dois ethé, como duas construções do Céu e da Terra.

Acrescentamos que ao final desse trabalho, na seção anexos, estão reproduzidos os enunciados que contemplamos nessa análise. Tais anexos não se inserem como fonte de 
análise ou como a expectativa de exame dos mecanismos de construção do sentido dos enunciados correspondentes a eles. Pelo contrário, trata-se da expansão ou explanação com finalidade ilustrativa apenas.

Vejamos a seguir os pressupostos teóricos determinantes às análises realizadas.

Como teremos textos verbo-visuais, iniciaremos a demonstração de pressupostos teóricos, com uma reflexão sobre sincretismo.

Partimos do conceito de sincretismo, tal como nos apresentam Greimas e Courtés (cf. 1986, p. 217), no qual o texto sincrético, ao operar com várias linguagens de manifestação, apresenta seu plano de expressão caracterizado por uma pluralidade de substâncias para uma forma única. Também tomamos como base a definição de Teixeira (2004, p. 11), a qual define como sincrético:

um objeto que, acionando várias linguagens de manifestação, está submetido, como texto, a uma enunciação única que confere unidade à variação. Objetos sincréticos para dizer com mais rigor, são aqueles em que o plano de expressão se caracteriza por uma pluralidade de substâncias mobilizadas por uma única enunciação cuja competência de textualizar supõe o domínio de várias linguagens para a formalização de uma outra que as organize num todo de significação (TEIXEIRA, 2004, p. 11).

O texto sincrético, ao articular diferentes linguagens, associa, segundo Teixeira (2004), uma personalidade que lhe é característica. As diferentes linguagens podem ser articuladas mediante um processo metonímico semântico, nas quais "as relações são produzidas por contigüidade de significação", ou por meio de um processo metonímico posicional, nas quais "as relações se constroem topologicamente" (cf. TEIXEIRA, 2004, p. 152).

Para que seja possível proceder à homologação das categorias do PC e do PE por meio de sua pluralidade de substâncias (plástica e lingüística) buscamos apoio nos desenvolvimentos teóricos da semiótica plástica desenvolvida por Floch $(1985,1987)$, da teoria dos sistemas semi-simbólicos e dos desenvolvimentos de Teixeira (2004). 
Assim, dentro dos objetivos de exame de mecanismos de construção do sentido das unidades recortadas para análise, consideraremos os diferentes "suportes intersemióticos" (cf. MAINGUENEAU, 2005a), dos quais se constituem os enunciados de divulgação religiosa das duas totalidades discursivas (Católica e Testemunha de Jeová), como textos sincréticos, ao operar a conjunção das categorias verbais e visuais.

Falamos em texto, ao tomar, por princípio, que a apreensão do sentido dos textos não é algo exterior e apriorístico ao signo, mas resultante da reunião dos dois planos compreendidos na linguagem (o plano da expressão e o plano do conteúdo). Um texto, seja visual, verbal ou sincrético, deve ser considerado como um todo de sentido. Se ele é um todo de significação, apresenta uma organização sintática e uma organização semântica responsáveis pela produção de sentido. Ao se entender o texto como um objeto que circula em uma sociedade, ele deve ser considerado em situação de comunicação, fato que pressupõe um enunciado em relação a uma enunciação. Ao considerar a organização interna e a inserção sócio-histórica de um texto, temos de examiná-lo como objeto de comunicação que possui coerções, devido a uma organização que produz sentido.

Assim, ao tomar a enunciação, como instância de mediação entre a língua e o discurso, e ao considerar o modo de presença do sujeito, como determinado pelo sistema de restrições semânticas da formação discursiva de que faz parte, buscamos depreender, por meio das relações entre enunciado e enunciação, o modo próprio de ver e perceber o mundo do sujeito inscrito na formação discursiva determinada e depreensível dos próprios textos. Mas a esse sujeito será acrescentada a investigação de seu corpo, voz, tom de voz e caráter, que é o éthos, princípio que orienta a noção de estilo e que ultrapassa o que Bakhtin (2003) propõe. Ora procuraremos o estilo dos gêneros de divulgação religiosa, ora o estilo das novas totalidades recortadas: Catolicismo e Testemunha de Jeová. 
Dentro dos objetivos de exame dos mecanismos de construção do sentido das unidades tomadas para análise, consideraremos os diferentes discursos e os diferentes tipos textuais de que se constituem os enunciados considerados, na medida em que se realizam como sistemas sincréticos, ao acionar diversas linguagens de manifestação.

A referência aos tipos textuais cobra um esclarecimento, já que elas constituem a composição dos gêneros do discurso de divulgação religiosa. Entende-se por tipos textuais, categorias mais gerais de organização dos textos, caracterizadas por apresentar categorias lingüísticas particulares.

Usamos a expressão tipo textual para designar uma espécie de seqüência teoricamente definida pela natureza lingüística de sua composição \{aspectos lexicais, sintáticos, tempos verbais, relações lógicas\}. Em geral, os tipos textuais abrangem cerca de meia dúzia de categorias conhecidas como: narração, argumentação, exposição, descrição, injunção. (MARCUSCHI, 2003, p. 22)

Ao tomar o percurso gerativo do sentido como ferramenta teórico-metodológica para desbastar o sentido dos textos considerados, valemo-nos do princípio geral de economia de leitura que ele proporciona ao trabalhar com níveis de complexificação e enriquecimento progressivos.

Vejamos a seguir como esses níveis são estruturados dentro da teoria semiótica.

A semântica do nível fundamental apresenta a oposição entre as categorias mais gerais e abstratas que estariam na articulação do sentido de um texto. Essas relações podem ser visualizadas por meio de um quadrado semiótico, com o estabelecimento do sentido construído mediante uma arquitetura de relações de contrariedade, contraditoriedade e complementaridade. Cada um dos termos do quadrado é selecionado com base em valores eufóricos ou disfóricos. Esse modo específico de axiologizar valores corresponde aos preceitos de uma determinada formação ideológica, o que nos permitirá depreender as 
categorias fundamentais em correspondência aos valores determinados pelo domínio social, ritualizado por meio da prática religiosa de ambas as totalidades.

O nível narrativo constitui o segundo patamar do percurso gerativo do sentido A partir das propostas estabelecidas por Vladmir Propp (1970) e por meio da visão da narrativa, como uma cena espetacular, a narratividade se apresenta como o fazer transformador do homem sobre o mundo, tanto no que se refere à busca de valores investidos nos objetos, quanto das relações contratuais estabelecidas entre destinador e destinatário.

O esquema narrativo canônico compõe-se de três percursos: o percurso da manipulação, o percurso da ação e o percurso da sanção. Cada percurso é composto por unidades elementares mais simples, denominadas de enunciados narrativos. Os enunciados narrativos compõem-se de enunciados de estado, pautados por relações transitivas estáticas e de enunciados de transformação, pautados por mudanças de relações juntivas.

A unidade funcional da narrativa é denominada de Programa Narrativo (PN), composto da união de, ao menos, dois enunciados de estado e um de transformação.

Os percursos narrativos, reconhecíveis como da manipulação, da ação (competência e performance) e da sanção, podem ser compreendidos como organizações hierárquicas de programas narrativos (PNs).

O percurso da manipulação apresenta a proposição de um contrato pelo destinador ao destinatário, com o objetivo de alterar a sua competência, levando-o a querer e dever fazer o que lhe foi proposto, para que ele entre, por conseguinte, em conjunção com o objeto valor almejado.

A organização do percurso da ação compreende um programa narrativo de performance e um programa narrativo de competência. Vejamos como Barros (2003, p. 199) procede à distinção entre eles: 
O programa narrativo de perfórmance é concebido como uma transformação de um estado de disjunção em um estado de conjunção, operada por um sujeito transformador que é realizado pelo mesmo ator do sujeito que tem seu estado transformado. Além disso, na perfórmance o valor do objeto é um valor descritivo final, isto é, o valor último a que visa o sujeito da narrativa. [...] Todo programa de perfórmance pressupõe um programa de competência. O programa de competência é também definido como uma transformação de um estado de disjunção em um estado de conjunção, mas, ao contrário do programa de perfórmance, o sujeito transformador é realizado por um ator diferente do sujeito de estado e o valor do objeto é um valor modal, isto é, um valor necessário para que o sujeito obtenha, na perfórmance, o valor descritivo último desejado (BARROS, 2003, p. 199).

O percurso da sanção compreende o percurso do destinador julgador que, ao verificar o cumprimento ou não do contrato proposto, estabelece a recompensa ou punição decorrentes. A sanção compreende duas fases: a sanção cognitiva, na qual o sujeito é ou não reconhecido como cumpridor do contrato, e a sanção pragmática, responsável pela atribuição da recompensa esperada ou pelo castigo.

Para operacionalizar a conversão das estruturas semionarrativas em discurso, tomamos a noção de enunciação, tal como proposta por Bertrand (2003, p. 84):

\begin{abstract}
Nesse percurso, a enunciação aparece então como a instância de mediação e conversão crucial entre as estruturas profundas e superficiais. Por meio da operação de "discursivização", ela organiza a passagem das estruturas elementares e semionarrativas virtuais, consideradas aquém da enunciação, como um estoque de formas disponíveis (uma gramática), para as estruturas discursivas (temáticas e figurativas), que as atualizam e especificam, em cada ocorrência, no interior do discurso que se realiza (BERTRAND, 2003, p. 84).
\end{abstract}

Dado que "a enunciação é a instância que povoa o enunciado de pessoas, de tempo e de espaço" (FIORIN, 2005a, p. 57), procederemos, por meio da sintaxe discursiva, à análise das marcas da enunciação no enunciado com a observação das operações correlatas de discursivização (actorialização, espacialização e temporalização), obtidas graças aos mecanismos de debreagem e embreagem. 
Longe de qualquer intenção psicologizante e atomizante, tomaremos como base a noção de pessoa do discurso, apoiada numa unidade sintática e, em princípio, despojada semanticamente, a que a semiótica denomina actante.

A experiência temporal, ao operacionalizar a articulação entre presente, passado e futuro, pode ser concebida como produto da construção humana. Desse modo, ao conceber o tempo como entidade linguageira e arbitrária, ou seja, efeito de sentido temporal, trataremos essa categoria lingüística a partir do "agora" instaurado pelo discurso e reinventado a cada ato enunciativo; e que se opõe, por sua vez, ao "então".

Desse modo, tomaremos o "agora" como fundamento das oposições temporais, eixo que articula a categoria topológica concomitância vs. não concomitância, que se articula, por sua vez, às noções de anterioridade e posterioridade.

A dicotomização dos sistemas temporais será observada, a fim de que possamos delinear e fundamentar dois ethé: A (Católico) e B (Testemunha de Jeová).

Para que possamos proceder à análise da espacialização dos discursos considerados, tomaremos como base a noção de espacialização, segundo a qual: o espaço lingüístico é determinado pela instância do "aqui" e reinventado a cada ato enunciativo.

Será curioso observar este diagrama (cf. FIORIN, 2002), para depreender a estrutura composicional dos gêneros de divulgação religiosa e verificar, depois, como se biparte cada estilo (Testemunha de Jeová ou Católico), segundo a seleção de um sistema temporal dado como dominante em textos de divulgação religiosa como aqueles pertencentes à totalidade Católica ou Testemunha de Jeová. 


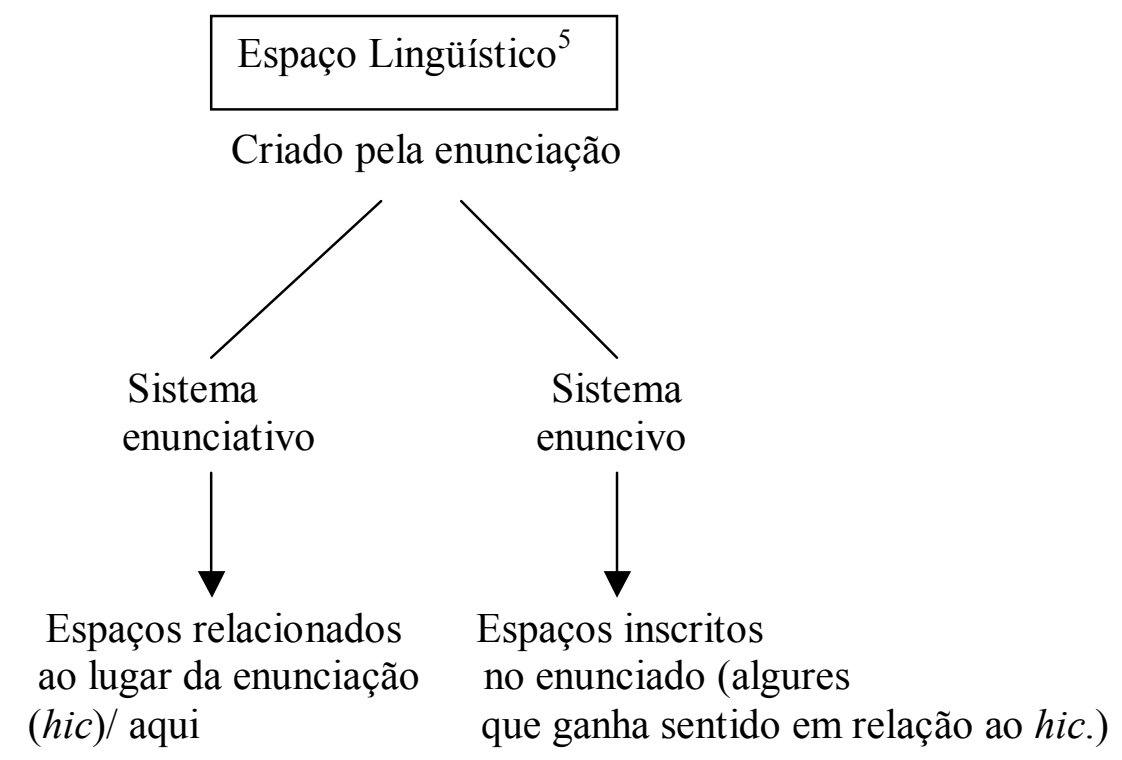

Em ambos os casos, o espaço figurativizado (na sala, em frente ao templo, à esquerda do padre, etc.), tido como o espaço tópico, recorta e especifica o espaço lingüístico representado no diagrama.

Os diferentes modos de transformar o espaço lingüístico em tópico, o que supõe diferentes figurativizações, remeterá ao éthos A ou ao éthos B (Católico e Testemunha de Jeová).

Tomaremos como base a noção de que o fundamento ideológico do discurso é reconstruído pela semantização de valores narrativos, bem como da ressemantização de temas, quando temos a polêmica examinada entre os discursos.

Cumpre esclarecer o emprego feito nessa dissertação da noção de ressemantização. Partimos dos fundamentos teóricos oferecidos por Maingueneau (2005a), ao tratar dos sistemas de restrições semânticas do discurso jansenista e do discurso humanista devoto.

Respaldados pelos parâmetros oferecidos para a descrição da semântica discursiva, tal como prevêem Greimas e Courtés (s.d, p. 397), como “a colocação em discurso (ou discursivização) das estruturas semióticas narrativas", depreenderemos de cada discurso um

\footnotetext{
5 DISCINI, Norma. Anotações de aula (curso: Tópicos da Teoria da Enunciação, ministrado no segundo semestre de 2005, na FFLCH/USP).
} 
conjunto de temas e figuras. Entretanto, esses temas e figuras se submetem aos "sistemas de restrições", que por sua vez, concretizam um ponto de vista, entendido como voz discursiva. Ora, se o discurso de divulgação religiosa se ancora no tema da inevitabilidade da morte, o discurso científico também poderá fazê-lo, mas ressemantizará esse tema de acordo com as expectativas da nova esfera de comunicação ou do novo discurso. Temos aí uma ressemantização temática entre diferentes esferas de comunicação ou entre diferentes discursos, entendidos, cada qual, como um conjunto de temas e figuras com um sistema próprio de restrições semânticas.

Pensando em divulgação científica e divulgação religiosa, também um tema como a inevitabilidade da morte sofrerá ressemantização, ou seja, será reconstruído segundo outros e diferentes parâmetros de fé, outros e diferentes argumentos que o iluminam de outras e diferentes formas.

Cada tema pressupõe uma determinada categorização do mundo. Não existe uma língua específica para um discurso, mas enunciados submetidos às restrições semânticas de cada ato enunciativo. Tais restrições fazem com que os enunciados sejam parte de um ou outro discurso, visto agora como um conjunto de temas e figuras.

Vejamos como Maingueneau (2005a, p. 73) procede à definição do que consiste um sistema de restrições semânticas:

Na medida em que o sistema de restrições não engendra enunciados, mas constitui somente um filtro de enunciados, esses esquemas e proposições não poderiam constituir a representação direta de enunciados realizados. São estruturas que regem a conformidade dos enunciados realizados às restrições de sua formação discursiva. A menor unidade discursiva supõe a colocação em ação do conjunto do sistema de restrições, e seu pertencimento à formação discursiva se manifesta por referência a esses esquemas de base, que são igualmente fórmulas de uma generalidade e de um rigor máximos, que cada enunciado especifica a sua maneira (MAINGUENEAU, 2005a, p. 73). 
Para definição dos procedimentos de tematização e figurativização inerentes aos enunciados instrucionais considerados, tomaremos como base a noção de que a tematização, ao reproduzir uma determinada categorização de mundo, dada linguageiramente por meio da ressemantização de temas, consolida os valores e ideais de uma determinada formação ideológica. Por conseguinte, a posterior conversão figurativa, apresenta como decorrência, por causa de uma maior ou menor densidade semântica atribuída, o aumento ou diminuição de ilusão referencial, concretude, particularização e simulação do real. Veremos como tais escolhas discursivas ratificam o éthos $\mathrm{A}$, em contraposição ao éthos $\mathrm{B}$.

Ao considerar o projeto de reformulação do modelo semiótico, realizado por Greimas e Fontanille, em seus últimos trabalhos, como Semiótica das paixões (1993), com a associação dos aprimoramentos epistemológicos e técnicos introduzidos ao modelo por Zilberberg (cf. 1988, 1990, 1992, 1996, 2006) e as inflexões teóricas que se vem fazendo nos últimos anos no Brasil, sobretudo no âmbito da canção, por meio dos trabalhos de Tatit (cf. 1997, 1999, 2001 2003, 2004), buscamos realizar uma breve incursão no que diz respeito à análise da categoria tensiva dos enunciados pertencentes ao espaço discursivo de divulgação religiosa.

O nível tensivo, tido como um nível de precondições para que se possa compreender as demais etapas do percurso gerativo do sentido, pressupõe o simulacro de um sujeito enunciador que estaria operando com a escolha de valores desde as etapas mais profundas do modelo gerativo.

Na base dos fenômenos de disjunção ou conjunção entre sujeito e objeto, de persuasão ou perda de confiança entre destinador e destinatário, das relações opositivas entre sujeito e anti-sujeito, residem as escolhas, efetuadas pelo enunciador do texto, dos valores intensos (responsáveis pelos limites, pelas disjunções, pelas paradas, pelas formas de concentração, enfim, pelas descontinuidades) ou extensões (responsáveis pelas gradações, pelas conjunções, pelas aberturas, pelas formas de expansão, enfim, pelas continuidades) e, sobretudo, do modo de entrosamento entre eles (TATIT, 2001, p. 113). 
Tomaremos a noção de ritmo na perspectiva de uma semiótica tensiva. Partiremos do princípio de homologia proposto por Hjelmslev (1975, p. 53-64) entre os dois funtivos (expressão e conteúdo) que contraem a função semiótica e das considerações sobre ritmo propostas por Pietroforte (2004a). Contrariamente a uma acepção de ritmo puramente estética, vista como um arranjo particular do plano da expressão, com apoio em Greimas e Courtés (1986, p. 386), optamos pela noção de ritmo vista como uma forma significante, associada tanto ao plano do conteúdo quanto ao plano da expressão.

Ritmo pode ser definido como uma espera (C. Zilberberg, na esteira de P. Valéry), ou seja, como a temporalização, conseguida mediante a aspectualidade incoativa, da modalidade do querer-ser, aplicada no intervalo recorrente entre agrupamentos de elementos assimétricos, que reproduzem a mesma formação. Contrariando a acepção corrente dessa palavra, a qual vê nela um arranjo particular do plano da expressão, optamos por uma definição do ritmo que o considera como uma forma significante, e, por conseguinte, da mesma natureza que os outros fenômenos de prosódia. Tal concepção libera o ritmo dos laços com o significante sonoro (o que permite falar em ritmo em semiótica visual, por exemplo) e mesmo com o significante tout court (o que confere a possibilidade de reconhecer um ritmo no nível do conteúdo, por exemplo) (GREIMAS; COURTÉS, 1986, p. 386).

Entendermos o ritmo, portanto, como manifestação de uma periodicidade, uma lei de sucessão reconhecida como uma percepção mais ou menos acelerada. A noção de ritmo será posta em dependência do andamento como medida de velocidade, o que corresponde, portanto, às modulações de velocidade na percepção que o sujeito tem do mundo discursivizado.

Tendo como base as noções anteriormente esboçadas, procederemos à tentativa de definição rítmica dos enunciados considerados para análise. Desse modo, tendo essas concepções em mente e ao tomar como base o que estabelece Zilberberg (1992), estabeleceremos a análise dos funtivos do andamento que perpassam os discursos considerados. 
A noção de ritmo, pouco abordada no âmbito semiótico, apresenta seus desenvolvimentos efetuados por meio dos trabalhos de Zilberberg, ao se valer das concepções de Valéry em seus Cahiers. Inicialmente, vejamos a noção de ritmo tal como nos apresenta Válery (1992, p. 1283-1284) apud Zilberberg (1996, p. 4):

Quando os acontecimentos entram em sucessão, quaisquer que sejam estes, se forem distintos, pode ocorrer que sejamos levados a percebê-los como se cada acontecimento fosse resposta ao acontecimento antecedente.

Dir-se-à então que o intervalo de tais acontecimentos está compreendido entre $\alpha$ e $\beta$. É da ordem da grandeza-tempo de um arco-reflexo - e supomos interiormente uma espécie de propagação ou funcionamento intermediário tal que (2) seja efeito de (1).

Toda lei percebida de uma sucessão é ritmo. Há lei, nesse sentido, quando uma dependência de se criar em mim entre os elementos de sua sucessão na sua ordem, tal que uma parte dos elementos fornecerá o todo, formando uma solicitação à qual responde o resto.

Zilberberg (1996), ao se valer da noção de ritmo proposta por Valéry (1992), que o define como uma espera entre dois estados sucessivos e intervalares, somada às concepções de Fraise (1974), que caracteriza a unidade rítmica por meio do contraste entre partes acentuadas e não-acentuadas, procede ao reconhecimento do ritmo como categoria semiótica.

Essa reflexão sobre o ritmo é estabelecida por meio da relação entre o tempo, o próprio ritmo e a duração. O tempo é considerado como termo regente, uma constante que “modaliza a duração da duração e a vivacidade do ritmo" (ZILBERBERG, 1990, p. 38).

Dessa maneira, ao desvincular o ritmo de sua acepção costumeira, ou seja, como elemento do plano da expressão, e ao partir à tendência de se ritmizar o plano do conteúdo, procederemos à definição do ritmo pela espera do que vai acontecer, seja na sucessão, seja na ordem espacial. A consciência do ritmo é advinda de uma consciência segunda, de uma forma sensível, organizando o campo perceptivo em função de "uma consciência intencional em situação (como /querer-ser/), ao que se permite aplicar uma topologização dinâmica sobre o 
intervalo recorrente entre elementos assimétricos reproduzindo a mesma formação" (GREIMAS; COURTÉS, 1986, P. 191).

Ao tomar a dimensão formal de sua apreensão por meio das noções de contínuo/descontínuo, sucessivo/simultâneo, podemos definir o ritmo como a manifestação de uma periodicidade, uma concepção de percepção construída como desdobramento da realidade perceptiva do ritmo.

Assim, o ritmo será compreendido como uma lei de sucessão percebida, uma percepção mais ou menos acelerada, uma percepção controlada segundo os funtivos do andamento.

A noção de ritmo, ao compreender a alternância entre tempos acentuados e não acentuados, é dependente em relação ao andamento. $\mathrm{O}$ andamento pode ser concebido como um complexo organizado segundo tempo e espaço.

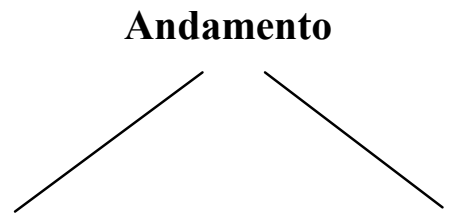

\section{Tempo}

\section{Espaço}

A experiência do espaço é regida pelo tempo, sendo esta regida pela velocidade. Assim, o andamento se coloca como medida de velocidade, que corresponde à presença de velocidades maiores ou menores na percepção que o sujeito tem do mundo feito discurso.

Essa é uma maneira de compreender as relações juntivas, na medida em que uma relação de conjunção ou disjunção somente é experienciada por um actante sujeito, caso a conjuntividade estabeleça alguma duração. A experiência do sujeito vai se alongando à medida que o andamento decresce. Teremos assim, experiências conjuntivas pautadas pela 
extensão, duração e apreensão do percurso; ou experiências construídas por mediação do instante, pautadas pela transição imediata, sem a experiência do percurso e sem duração que apresente uma continuidade possível, o que pode remeter à práxis semiótica apreendida em suas duas dimensões: a intensidade (sensível) e a extensidade (inteligível).

Os elementos intensos correspondem à saliência, já que são compactos, "implosivos", transitivos; seu campo de ação é local; trata-se, grosso modo, de elementos nominais, nominalizantes e nominalizados. Os elementos extensos, por sua vez, correspondem à "passância", já que são desdobrados, "explosivos", reabsorventes; nesse sentido eles tecem a cadeia; trata-se, sempre sumariamente, de elementos verbais, verbalizantes ou verbalizados (ZILBERBERG, 2006, p. 132).

Vejamos, por fim, como Zilberberg (1990, p. 45) procede à associação entre essas noções:

O tempo se vale das estruturas rítmicas, a saber do jogo dos acentos, das pausas e dos intervalos, para lhes submeter à celeridade ou à lentidão e nós já indicamos que a lentidão se realiza como extensão e a celeridade como concentração. Da lentidão é suficiente dizer que ela "toma seu tempo", "todo seu tempo", que ela se oferece ao tempo", que o sujeito lento estende a duração diante de si e a usufrui. A lentidão é uma cronopoiése. A duração da duração vem assim se constituir como um objeto interno tendo vocação a tornar possível, confortável a conjunção do sujeito com o objeto. (ZILBERBERG, 1990, p. 45)

Verificaremos, portanto, como os textos que materializam o espaço discursivo de divulgação religiosa alcançam certa especificidade rítmica para que se defina a cena enunciativa.

Ao conceber a identidade, como efeito de sujeito dado como simulacro discursivo de um ator da enunciação pressuposto ao enunciado, devemos remeter à noção de estilo definido como efeito de individuação do discurso, produto das relações entre o plano do conteúdo e o plano da expressão dos textos. Tal noção corresponde, por sua vez, à noção de éthos, visto como tom, voz, caráter e corporalidade pressupostos à totalidade enunciada. 
Dessa forma, ao conceber a identidade como: uma recorrência de estratégias que delineiam um modo próprio de ser, também se presentificam estratégias de ver e perceber o mundo.

Assim, com apoio nos estudos sobre Presença de Fontanille e Zilberberg (2001, p. 123-151) e dos desenvolvimentos efetuados por Discini (2005c), buscamos articular a noção de estilo à aspectualização do ator da enunciação. $\mathrm{O}$ aspecto é definido em lingüística como "um ponto de vista sobre o processo" (BERTRAND, 2003, p. 415).

Consideraremos a aspectualização, segundo Greimas e Courtés (1986, p. 28), como a “disposição, no momento da discursivização, de um dispositivo de categorias aspectuais mediante as quais se revela a presença implícita de um actante observador”. Esse observador é dado como "ponto de vista sobre a ação" (GREIMAS; COURTÉS, 1986, p. 29), para o qual também se inscrevem a temporalização e a espacialização.

Ao considerar a tensividade-fórica como uma espécie de proto-sintaxe responsável pelas modulações tensivas e fóricas, uma instância profunda e pressuposta às demais etapas do modelo gerativo, na qual também se pressupõe o simulacro de um sujeito enunciador que estaria operando a escolha de valores desde as etapas mais profundas que as já consideradas do modelo gerativo, devemos remeter ao conceito de presença.

A própria noção de um corpo que percebe e sente estabelecida pela fenomenologia de Merleau-Ponty (1994), pode ser homologada à instância do sujeito enunciativo, pressuposto ao enunciatário e reconhecido por Fontanille e Zilberberg (2001) desde as etapas mais profundas do modelo. Esse sujeito, ao se transformar em ator provido de uma localização espaço-temporal, instala um centro dêitico e exerce um fazer seletivo, operando a escolha de valores e a instituição de axiologias desde as etapas mais profundas do modelo. Um sujeito, que está instaurado na interface temporal e espacial, responsável pela seleção de valores de continuidade e descontinuidade e sua posterior conversão em objetos narrativos. Um sujeito 
responsável pela seleção de valores temporais ou aspectuais, uma seleção de valores de andamento e que podemos remeter à escolha de regimes de aceleração ou desaceleração.

A percepção, ao ser controlada pelas noções de tempo e andamento, corresponde a uma percepção mais ou menos acelerada. Assim, como o espaço é dado pelo olhar do sujeito que constrói esse espaço, pensa-se na aspectualização do ator. O observador, como sujeito da percepção, está nessa articulação do tempo visto como andamento.

Dessa forma, ao tomar o actante observador como sujeito cognitivo, e, portanto, sujeito da cognição, dado como efeito de sentido, buscamos o estabelecimento do modo de presença em compatibilidade ao sistema de restrições da totalidade discursiva considerada, mas falamos de um aquém do percurso gerativo.

Ao tratar o modo pelo qual se dá o investimento temático e figurativo dos textos em análise, devemos levar em conta o éthos e a ideologia subjacentes, na medida em que o texto, qualquer que seja o seu gênero discursivo, busca reproduzir o imaginário social.

Ainda sobre o éthos (tom, voz, caráter e corporalidade) subjacente ao texto, construído por uma recorrência de características observáveis no plano do conteúdo e no plano da expressão, este pode ser recuperado por meio da apreensão do sujeito em relação ao enunciado devido à conversão de percursos narrativos em percursos temáticos e seu posterior revestimento figurativo, com vistas a se criar efeitos de realidade, mediados pela enunciação. Ainda para entender o éthos, observaremos o sujeito da percepção, o observador, não apenas como o sujeito cognitivo que se emparelha ao narrador do nível discursivo, mas o observador que apreende o mundo segundo um ritmo e, ao imprimir um ritmo a seus discursos, contribui para a fundamentação do éthos.

Ao tomar como base que: a discursivização da paixão tem como característica essencial a projeção e operacionalização dos simulacros que cada um dos interlocutores envolvidos dirige um ao outro, observamos que, no espaço discursivo de divulgação religiosa, 
essa operacionalização se dá em duas vertentes: do arquidestinador (Deus) para o destinador (agente religioso) e desse para os destinatários (fiéis), no que diz respeito a cada uma das totalidades cotejadas (Católica e Testemunha de Jeová). Desse modo, veremos emergir diferentes imagens de enunciatário com base em cada uma das cenas enunciativas cotejadas.

Depreenderemos, assim, o modo recorrente de dizer, que remete ao modo recorrente de ser e perceber do sujeito linguageiro inscrito no discurso, para o qual estabeleceremos o éthos das cenografias consideradas. Assim, definiremos o estilo como efeito de individuação do discurso, produto das relações entre o plano do conteúdo e o plano de expressão dos textos.

Dentro dos objetivos de exame dos mecanismos de construção do sentido, segundo os quais se concretiza a "interincompreensão constitutiva" (cf. MAINGUENEAU, 2005a) como "primado do interdiscurso", no que diz respeito a textos de diversos gêneros (catecismo, revista, panfleto, etc.) que materializam o espaço discursivo de divulgação religiosa de duas totalidades em confronto, pode-se considerar como e por que podemos depreender dois modos diferentes e conflitantes de presença, dois estilos, que remetem a dois modos de ser, dos quais se depreendem dois ethé (A e B), como duas imagens do sujeito enunciador bipartido em profissão de fé.

Inferiremos, portanto, o corpo depreensível de cada totalidade religiosa, mediante o embate entre duas interincompreensões e determinado por distintos modos de discursivização de temas e figuras, a fim de que possamos confirmar a construção de um éthos e de um antiéthos estabelecido entre os textos de divulgação religiosa de ambas as totalidades: A (católica) e B (Testemunha de Jeová). 


\section{CAPÍTULO I - Breve histórico sobre as religiões cristãs, com recorte prioritário para o Catolicismo e a Testemunha de Jeová}

"Não existe para a religião, bem como para muitas outras ciências e filosofias, uma explicação ou definição precisa. A religião, como a história, é um livro que se abre pelo meio".

Leonardo Antunes Marques ${ }^{6}$

Para que possamos proceder a um breve histórico das religiões consideradas, tomaremos como pressuposto que o estudo das religiões representa o compromisso com o conhecimento e não com verdades absolutas. Desse modo, propomos apresentar um breve histórico das religiões consideradas, sem de forma alguma buscar estabelecer um discurso de apologia a quaisquer das religiões em pauta, mas tão somente analisar as origens, os desenvolvimentos e as características que as singularizam como tais.

A etimologia da palavra religião, proveniente do latim re-ligio, com a mesma raiz da palavra religar, teria, segundo Pietroforte (1997, p. 39), “a conotação de religar uma suposta natureza humana com uma suposta natureza divina”. Entretanto, ao nos valer dessa explicação do fenômeno religioso, estaríamos atados a uma interpretação cristã da queda e do pecado original de Adão. Como essa explicação apresenta um caráter não universalizante e restritivo ao universo cristão, e como nos preocupamos com o conhecimento, não segundo verdades absolutas e supostamente restritivas, tomaremos como a base a definição de Marques (2005, p. 20), para a qual "a religião é a revalorização do sagrado".

Tomamos, como ponto de partida dessa caracterização do fenômeno religioso, o estabelecimento da oposição entre a categoria sagrado versus a categoria profano. Desse modo, essa primeira definição, pautada pelo estabelecimento de uma unidade caracterizadora desse discurso e mediante a diversidade de fatos religiosos, toma como ponto de partida a

\footnotetext{
${ }^{6}$ MARQUES, Leonardo Antunes. História das religiões e a dialética do sagrado. São Paulo: Madras, 2005. p. 18.
} 
articulação entre um saber laico, profano e situado no terreno do cognitivo, ao que se opõe um saber especial, sagrado, situado no terreno do ser e representado pelo crer.

De acordo com Eliade (2004, p. 7), “todas as definições do fenômeno religioso apresentadas até hoje mostram uma característica comum: à sua maneira, cada uma delas opõe o sagrado e a vida religiosa ao profano e a vida secular".

Podemos, de acordo com Pietroforte (1997), caracterizar essa oposição da seguinte forma:

Pode-se dizer que há basicamente uma divisão entre, de um lado, afazeres ditos profanos centrados em fatos cotidianos cujo eixo é o espaço-temporal imediato, ou seja, a realidade mundana e, de outro, afazeres ditos sagrados, centrados em fatos especiais cujo eixo transcende aquele eixo espaçotemporal, colocando-se em uma realidade supra-mundana, só acessível mediante uma prática simbólico-ritual. Portanto, há um eixo que se pode dizer horizontal, identificado como um processo histórico relativo, e um eixo que se pode dizer vertical identificado como um processo supra-histórico absoluto (PIETROFORTE, 1997, p. 15).

Para o desenvolvimento desse trabalho, partimos da perspectiva da religião entendida na acepção de mito.

O mito é uma explicação das origens do homem, do mundo; da linguagem; explica o sentido da vida, a morte, a dor, a condição humana. Vive porque responde à angústia do desconhecido, do inexplicável; dá sentido àquilo que não tem sentido (FIORIN, 2002, p. 10).

Tomemos as proposições de Eliade (2004, p. 11) concernentes à definição de mito. Segundo o autor, os mitos se caracterizam primordialmente pelo seu caráter veridictório, "o mito fala apenas do que realmente ocorreu, do que se manifestou plenamente", por oposição às fábulas e contos, que não precisam apresentar necessariamente esse caráter de veridicção" (ELIADE, 2004, p. 11).

Segundo Eliade (1993), o mito possui como função primordial fornecer e fixar modelos e justificativas de todos os ritos e ações humanas significativas. 
Qualquer que seja a sua natureza, o mito é sempre um precedente e um exemplo, não só em relação às ações - "sagradas" ou "profanas" - do homem, mas também em relação à sua própria condição. Ou melhor: um precedente para os modos do real em geral. "Nós devemos fazer o que os deuses fizeram no princípio". "Assim fizeram os deuses, assim fazem os homens" (ELIADE, 1993, p. 339).

De acordo com Campbell (2005, p. 24-25), os mitos podem ser divididos em duas categorias distintas:

Os mitos são metáforas da potencialidade espiritual do ser humano, e os mesmos poderes que animam nossa vida animam a vida do mundo. Mas há também mitos e deuses que têm a ver com sociedades específicas ou com as deidades tutelares da sociedade. Em outras palavras, há duas espécies totalmente diferentes de mitologia. Há a mitologia que relaciona você com sua própria natureza e com o mundo natural, de que você é parte. E há a mitologia estritamente sociológica, que liga você a uma sociedade particular. Você não é apenas um homem natural, é membro de um grupo particular. [...] Ora, a tradição bíblica é uma mitologia socialmente orientada (CAMPBELL, 2005, p. 24-25).

A linguagem mítica constitui uma linguagem simbólica ou significativa, por oposição à linguagem designativa, informacional e utilitária dos objetos. Vejamos como Lótman e Uspenskii (1981, p. 141) procedem à definição dessa linguagem:

De tudo quanto temos dito conclui-se que a consciência mitológica é, por princípio, intraduzivel, numa descrição de um outro plano, que está fechada em si própria, e que apenas se compreende, portanto, desde o interior e não desde o exterior. Isto é-nos dado, em particular, pelo tipo de semiose própria da consciência mitológica e encontra um paralelo lingüístico no intraduzível dos nomes próprios (LÓTMAN; USPENSKII, 1981, p. 141).

A verdade proposta pelo mito é uma verdade simbólica: "ela propõe para o mundo, para a vida e para as relações humanas, um sentido que não se pode impor nem demonstrar; ou embarcamos nele ou não, ou o poder do fascínio do mito exercerá seu efeito, ou não nos atingirá!" (DABEZIES, 1997, p. 734). 
Assim, observamos que a ação simbólica mobilizada pela religião consiste em incutir valores ideológicos, éticos e morais, em conformidade com a formação ideológica na qual se acha instaurado.

\section{Cristianismo}

O Cristianismo tem sua origem na confluência de diversos pensamentos e crenças como o misticismo oriental, o messianismo judeu, o pensamento grego e o universalismo romano.

Caracteriza-se como a religião dos cristãos, uma religião monoteísta, histórica e tida como revelada. Tais princípios religiosos são oriundos dos ensinamentos de Jesus, considerado filho de Deus para os cristãos. O início da era cristã é dado a partir do nascimento de Jesus em Belém da Judéia no ano "I". A comunhão com Deus seria intermediada pela figura de Jesus, tido como o salvador da humanidade. Assim, podemos estabelecer a seguinte profissão de fé para o Cristianismo: "Só há um Deus verdadeiro, justo e Todo-Poderoso, e Jesus Cristo, seu filho unigênito, o único e exclusivo caminho para a salvação" (MARQUES, 2005, p. 137).

\footnotetext{
A mensagem central do Cristianismo consiste, por conseqüência, em dizer que Jesus é o Cristo, o enviado de Deus, aquele que revela a obra e salvação de Deus. A revelação única entre Deus e Cristo exprime-se nos termos Pai e Filho (MARQUES, 2005, p. 144).
}

Tomemos como base o seguinte texto extraído do Novo Testamento (Mc 10, 29-30), tido como a proclamação do Evangelho de Jesus Cristo segundo Marcos. Vejamos como, no 
texto, tal "mensagem central", entendida aqui como núcleo temático de uma configuração (inter)discursiva, pode ser identificada.

${ }_{29}$ Jesus declarou: Em verdade vos digo que não há quem tenha deixado casa, irmãos, irmãs, mãe, pai, filhos ou terras por minha causa e por causa do Evangelho, 30 que não receba cem vezes mais desde agora, neste tempo, casas, irmãos e irmãs, mãe e filhos e terras, com perseguições; e, no mundo futuro, a vida eterna (BÍBLIA de Jerusalém, 2004, p. 1774).

O núcleo temático dessa configuração interdiscursiva pode ser representado por meio da temática da salvação. Observamos a presença de figuras que remetem à isotopia da riqueza, estabilidade e prosperidade (casa, irmãos, irmãs, mãe, pai, filhos e terras). Institui-se uma sanção positiva de reconhecimento ao sujeito que se despojar dos valores materiais (temporais) pertencentes à isotopia da estabilidade. Assim, para que o sujeito possa alcançar o $\mathrm{O}_{\mathrm{v}}$ "graça divina", figurativizado pela "vida eterna", deve apresentar um desprendimento, um desapego aos bens materiais (temporais) e proceder à busca de valores espirituais, figurativizados pelo percurso da sacralidade e da comunhão com a Igreja.

Como muitos outros considerados fundadores de diversas religiões ou religiosidades, Jesus nada deixou documentado a respeito de seu pensamento e doutrina. Tudo de que dispomos se encontra presente nos Evangelhos. De acordo com sua etimologia, a palavra Evangelho, originária do grego evangélion, besoura em hebraico, teria como significado "Boa Nova", expressão utilizada originalmente nos textos primitivos para designar os ensinamentos da doutrina cristã, a qual, posteriormente, passa a ser empregada como designação dos livros ou documentos que contêm a história das origens do cristianismo.

Todo o Cristianismo baseia-se nos escritos bíblicos, tidos como autoridade suprema por expressar a "Palavra de Deus". A Bíblia na versão católica compõe-se de um conjunto de 72 livros, desses, 45 pertencem ao Antigo Testamento e 27 ao Novo Testamento. No que diz 
respeito à versão protestante, seus 66 livros estão divididos entre 39 no Velho Testamento e 27 no Novo Testamento.

\subsection{Catolicismo}

O Catolicismo é tido como o maior ramo do Cristianismo e o mais antigo como Igreja organizada. A etimologia da palavra é originária do grego katholikos, 'universal' e representa a universalidade do "todo" da Igreja e de sua doutrina.

Teríamos em primeiro lugar, a Igreja universal e missionária, tal como se expressa no Credo: Creio na Igreja una, santa, católica e apostólica. E, em segundo lugar, a doutrina e sua práxis, aceita por todos, sempre e em toda a parte, segundo a fórmula de S. Vicente de Lerins (SANTIDRIÁN, 1996, p. 99).

O termo catolicismo significa, portanto, a "grande Igreja" universal que, apoiada em uma doutrina e tradição comuns, pode levar a salvação a qualquer pessoa, em qualquer lugar do mundo.

O catolicismo foi o responsável pela organização dos Evangelhos e por muitas das características e crenças apresentadas pelo cristianismo, seguidas pelos cristãos nos dias de hoje, independentemente de suas ramificações, tais como: o Pecado Original, a Trindade, o Batismo, a Escatologia Bíblica, os Sacramentos e o Casamento.

A origem e consumação dessa fé podem ser estabelecidas pelas palavras e ações de Jesus Cristo, concretizadas mediante sua morte redentora e ressurreição.

A Igreja católica pode ser considerada como a herdeira do Estado Romano, na medida em que sua história está associada à expansão do Império Romano, com o surgimento de 
novos reinos. O desenvolvimento do catolicismo como religião oficial do Estado Romano tem origem em 313, com Constantino. O Concílio de Nicéia, realizado em 20 de maio de 325 em Nicéia (atual Turquia), pode ser considerado como o primeiro a realizar a normatização e legitimação do pensamento cristão, no qual se deu a separação entre os Evangelhos canônicos e apócrifos.

De maneira geral, podemos caracterizar o catolicismo como "o conjunto dos cristãos e das comunidades cristãs que reconhecem a jurisdição do Bispo de Roma, a quem chamam Papa" (MARQUES, 2005, p. 152). Estão incorporados à Igreja Católica “quem, tendo o Espírito de Cristo, está unido a ela por vínculos da profissão de fé, dos sacramentos, do governo eclesiástico e da comunhão” (BENTO XVI, 2005, p. 63).

O catolicismo caracteriza-se por apresentar uma rígida hierarquia, centrada na autoridade Papal, que é eleita pelo colegiado superior da Igreja.

De acordo com o contexto católico, o apóstolo Pedro (Simão) foi nomeado o primeiro Papa, e sobre ele se edifica toda a Igreja Católica: "Também eu te digo que tu és Pedro, e sobre esta pedra edificarei a minha Igreja, e as portas do Hades nunca prevalecerão sobre ela" (Mt 16, 18) (BÍBLIA de Jerusalém, 2004, p. 1733-1734).

A sucessão apostólica é característica dessa formação ideológica, sempre que morre um Papa, outro deve assumir seu lugar. O Papa é considerado sucessor direto do apóstolo Pedro e vigário de Jesus Cristo. O atual Papa é o alemão Joseph Ratzinger, Bento XVI, eleito em 19 de abril de 2005, como sucessor do Papa João Paulo II.

Nessa sociedade hierarquicamente estruturada, abaixo do Papa colocam-se os cardeais, arcebispos, bispos e clérigos, dividindo-se este último em clero secular e regular. Os fiéis, leigos, dirigidos pelo clero, devem exercer o múnus sacerdotal, tido como tarefa sagrada, tendo por objetivo difundir a Boa Nova católica. 
A doutrina católica tem como principais características a veneração aos santos, tidos como intermediários entre Deus e os homens e os dogmas de Maria. O catolicismo adota o conceito do Pecado Original proposto por Santo Agostinho, apregoa o celibato entre os dirigentes de suas comunidades, a crença na trindade e a "unção" pelo Espírito Santo.

Tomando como base a etimologia da palavra catolicismo, observamos que a missão da Igreja, ao anunciar a Boa Nova de Jesus e conduzir a humanidade ao seu fim último, apresenta as seguintes partes constituintes: evangelização, santificação e pastoreio.

A doutrina cristã é ensinada aos fiéis por meio da realização da catequese.

A catequese é uma educação da fé das crianças, dos jovens e dos adultos, a qual compreende especialmente um ensino da doutrina cristã, dado em geral de maneira orgânica e sistemática, com o fim de os iniciar na plenitude da vida cristã (JOÃO PAULO II, 2000, p. 14).

A catequese articula-se em torno dos seguintes elementos da missão pastoral da Igreja: “primeiro anúncio do Evangelho ou pregação missionária para suscitar a fé; busca das razões de crer; experiência de vida cristã; celebração dos sacramentos; integração na comunidade eclesial; testemunho apostólico e missionário" (JOÃO PAULO II, 2000, p. 14).

A economia sacramental católica "consiste em comunicar os frutos da redenção de Cristo, mediante a celebração dos sacramentos da Igreja, principalmente da Eucaristia" (BENTO XVI, 2005, p. 79).

Os sacramentos são sinais eficazes de graça, instituídos por Cristo e confiados à Igreja, por meio dos quais nos é dispensada a vida divina. Os ritos visíveis sob os quais os sacramentos são celebrados significam e realizam as graças próprias de cada sacramento. Produzem efeito naqueles que os recebem com as disposições exigidas (JOÃO PAULO II, 2000, p. $319)$.

São sete os sacramentos da Igreja: Batismo, Confirmação, Eucaristia, Penitência, Unção dos Enfermos, Ordem e Matrimônio. Eles apresentam a seguinte distinção: 
sacramentos de iniciação cristã (Batismo, Confirmação e Eucaristia); sacramentos da cura (Penitência e Unção dos Enfermos); sacramentos a serviço da comunhão e da missão (Ordem e Matrimônio).

A antropologia revela que a presença de lugares sagrados é comum a todas as religiões e crenças. O caráter sacro, reservado às Igrejas Católicas, remete à presença de Jesus no sacrário. Para essa formação discursiva, Jesus está presente Igreja o tempo todo na forma de pão (hóstia consagrada), que é o seu próprio corpo, uma presença material e concreta. Símbolos e sinais como a presença do crucifixo, o confessionário, os temas dos vitrais e as estações da via-sacra constituem elementos que nos ajudam a focalizar e compreender as verdades e os mistérios da fé católica.

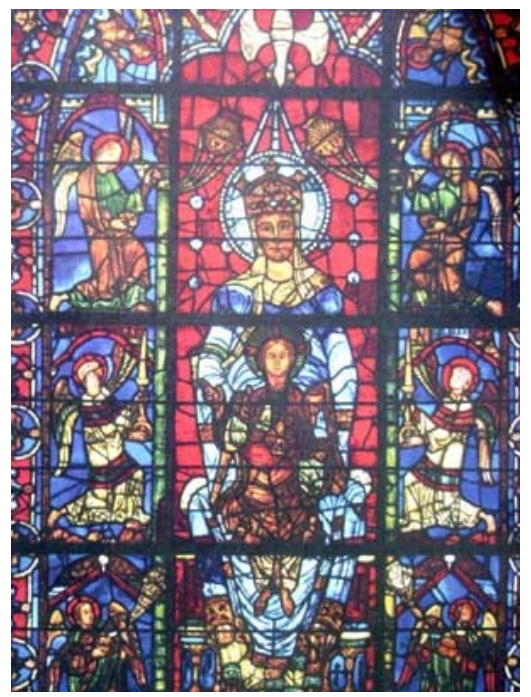

Ilustração 1 Vitral de Notre-Dame-de-la-Belle-Verrière (Nossa Senhora do Belo Vitral). 4,90 x 2,36m. Primeira janela da Colateral do coro, lado sul.Catedral de Chartres.

Os fiéis devem confessar-se aos padres e freqüentar a missa, tida como rito católico essencial. O sacrifício da missa, determinado como legítimo centro da fé católica, é de fundamental importância para o relacionamento do homem com Deus. Na missa é celebrado de modo sacramental o mistério da vida, morte e ressurreição de Cristo, ato de amor responsável pela transformação, conversão e cura daqueles que o recebem. 
A celebração da missa recebeu inúmeras denominações, cada uma delas, enfatizando diversos aspectos de observância: "o partir do pão"; "a ceia do Senhor"; "o sacrifício"; "a liturgia".

A missa é o principal ato litúrgico católico, cujo ponto culminante é representado por meio do banquete eucarístico, momento da transubstanciação do próprio corpo e sangue de Jesus sob as espécies do pão (hóstia) e vinho.

Transubstanciação significa a conversão de toda a substância do pão na substância do corpo de Cristo e de toda a substância do vinho na substância do seu Sangue. Essa conversão se realiza na oração eucarística, mediante a eficácia da palavra de Cristo e da ação do Espírito Santo. Todavia, as características sensíveis do pão e do vinho, ou seja, as "espécies eucarísticas", permanecem inalteradas (BENTO XVI, 2005, p. 95).

A celebração da Eucaristia tem sua origem, segundo o catolicismo, com Jesus Cristo. Vejamos a seguinte passagem do Novo Testamento, extraída de Marcos (14, 22-25), tida como origem da instituição da Eucaristia:

22 Enquanto comiam, ele tomou um pão, abençoou, partiu-o e lhes deu, dizendo: "Tomai, isto é o meu corpo". ${ }_{23}$ Depois tomou um cálice, rendeu graças, deu a eles, e todos dele beberam. ${ }_{24} \mathrm{E}$ disse-lhes: "Isto é o meu sangue, o sangue da Aliança, que é derramado em favor de muitos. ${ }_{25} \mathrm{Em}$ verdade vos digo, já não beberei do fruto da videira até aquele dia em que beberei o vinho novo do reino de Deus" (BÍBLIA de Jerusalém, 2004, p. 1781).

A celebração eucarística é composta de duas partes: Liturgia da Palavra e Liturgia Eucarística. Além dessas partes, também há os Ritos Iniciais e Ritos Finais.

Os ritos iniciais são o começo da celebração, por meio da realização do canto de entrada, o sinal da cruz, a saudação do penitente, o ato penitencial, o hino de louvor (Glória) e a oração chamada "coleta". Os ritos iniciais têm como objetivo preparar e harmonizar o fiel com a recepção curativa do amor de Deus. Persignar-se com água benta e realizar o sinal da cruz constituem maneiras de purificação e preparação para entrar em conjunção com a 
presença do Senhor. O rito penitencial é para o catolicismo a chave da recepção curativa da missa, pois o fiel, ao confessar suas fraquezas e faltas, torna-se mais receptivo ao perdão do Senhor e aberto à dimensão curativa desse ato.

No Glória, o fiel coloca-se em louvor a Jesus diante do Pai.

A primeira parte da missa tem por objetivo preparar o fiel a estar receptivo à palavra de Deus. O fiel é chamado à presença divina, convidado a estar unido em oração. Quando o sacerdote diz "oremos", a comunidade é convidada a participar da Oratio, oração inicial da missa, considerada de grande poder curativo, de acordo com Degrandis e Schubert (2004).

Todas as partes iniciais da missa culminam na liturgia da Palavra. As partes iniciais são caracterizadas como preparatórias como abertura à adequada recepção da palavra divina.

O tema que perpassa as orações, as respostas, os salmos e os cânticos sugeridos para a missa concentram-se nas leituras bíblicas.

A Liturgia da Palavra tem início com a primeira leitura, prosseguindo com o salmo responsorial, a segunda leitura, a aclamação do evangelho, a leitura do evangelho, a homilia, a profissão de fé e a oração dos fiéis (preces da comunidade).

A Liturgia Eucarística se inicia com a apresentação e oração sobre as oferendas, prossegue com a oração eucarística, o Pai-Nosso, a invocação ao cordeiro de Deus, o canto de comunhão e a oração após a comunhão.

Durante a apresentação das dádivas, os representantes da comunidade trazem as espécies eucarísticas do pão e do vinho, bem como outras dádivas a serem recebidas com a coleta. A liturgia eucarística iniciada por meio da realização da doação (coleta), ao configurar a adoração do Senhor com os recursos dos fiéis, os coloca em posição de receber a Deus.

A consagração da missa, realizada por meio da transubstanciação das espécies eucarísticas do pão e do vinho, provoca, segundo esse contexto, uma transformação espiritual em todas as pessoas presentes. 
A recepção da santa comunhão constitui a presença de Jesus na celebração eucarística, proporcionando a cura física, espiritual, emocional e psicológica àqueles que a recebem (cf. DEGRANDIS; SCHUBERT, 2004).

Os Ritos Finais se iniciam com a benção de despedida, seguida da realização do canto final e da oração pelas vocações.

Todas as partes de que se compõe a missa tem como objetivo auxiliar no processo curativo e de benção: ritos iniciais, liturgia da palavra, liturgia eucarística e rito de conclusão. "No rito de conclusão, a bênção do sacerdote desperta o sacramento da confirmação, que nos ordena partilhar Jesus Cristo com os outros - por exemplo, rezando com eles e por todos os meios que o Senhor indicar (DEGRANDIS; SCHUBERT, 2004: 148)”.

As missas eram celebradas em latim até meados dos anos 60. Com a autorização do Concílio Vaticano II, as missas passaram a ser celebradas na língua do próprio país.

Ao tomarmos como base os dados da Arquidiocese de São Paulo, podemos destacar as publicações efetuadas em meio impresso como o mais antigo e acentuado meio de comunicação da Igreja. O estado de São Paulo apresenta a maior concentração de editoras de livros, jornais e revistas católicas do Brasil. Oito das maiores editoras da Igreja em caráter nacional pelo número anual de títulos e volumes publicados (Vozes, Paulinas, Paulus, Ave Maria, Salesiana, Loyola, FTD -Frère Teophane Durand e Cidade Nova) encontram-se presentes nesse estado. O Brasil possui 82 livrarias católicas, sendo 19 em São Paulo e 63 nos demais estados brasileiros. Podemos destacar como meios de divulgação religiosa católica: livros, jornais, revistas, boletins mensais, boletins litúrgicos semanais, vídeos, discos, cassetes, Compact Disc (CD) e novas tecnologias.

Segundo os dados da edição do "Anuário Pontifício 2006”, o número de católicos ao redor do mundo atinge a soma de 1,098 bilhões de fiéis. 
Os dados do Censo Demográfico realizado pelo IBGE em 2000 demonstram que, em números absolutos, apesar do declínio do catolicismo no Brasil mediante o avanço do neopetencostalismo e das pessoas "sem religião", o catolicismo ainda se apresenta como religião majoritária. Em 2000, temos 125.517 .222 católicos declarados, o que representa a média de $73,9 \%$ da população brasileira.

\subsection{Crenças de Referencial Cristão: Neocristianismo}

Além do Catolicismo Romano e Ortodoxo e o do Protestantismo Luterano ou Calvinista, verificamos a presença de outras maneiras de pensar o sagrado e de refletir sobre ele, também determinadas pelo referencial cristão. Atribuiremos a essas crenças, com apoio em Jacob (2003) e Marques (2005), a denominação de religiões neocristãs ou crenças de referencial cristão. Podemos citar como pertencentes a esse grupo a religião das Testemunhas de Jeová, a Igreja de Jesus Cristo dos Santos dos Últimos Dias, a qual é mais conhecida sob a denominação de Mórmons, e a religião da Boa Vontade/ Religião de Deus. Dado os propósitos desse breve histórico, nos ateremos, a seguir, unicamente, ao referencial das Testemunhas de Jeová. 


\title{
1.2.1 Testemunhas de Jeová (TJ)
}

As atividades das Testemunhas de Jeová (doravante TJ) tiveram início na década de 1870. Inicialmente chamadas de "Estudantes da Bíblia", adquiriram a denominação de Testemunhas de Jeová em 1931.

Com um pensamento religioso de forte cunho milenarista e nominalista, a TJ teve a sua fundação no início do século XIX em 1881 por Charles-Taze Russel (1852-1916) nos Estados Unidos. Com um forte cunho profético, Russell havia anunciado para 1914 a próxima vinda de Cristo, que poria fim ao reinado do mal e inauguraria "o reino de Deus" por mil anos àqueles que aceitassem a soberania divina. Devido ao seu fracasso, Russel se viu obrigado a reinterpretar sua profecia. O seguidor e sucessor de Russel, o juiz de direito Joseph Franklin Rutherford (1869-1942) precisou a data do acontecimento profético para 1925, sendo obrigado posteriormente a dar um sentido invisível e espiritual a esse acontecimento.

Podemos configurar esse pensamento religioso como milenarista devido à crença apresentada em duas fases do Cristianismo:

\begin{abstract}
A primeira é a morte do cordeiro na cruz e a sua ressurreição como prova do poder de Deus, e a segunda será no juízo final, quando Jesus aparecerá resplandecente de glória e julgará a todos, permanecendo no paraíso apenas aqueles que seguiram a Bíblia como palavra de Deus. Após essa fase, Jesus reinará por mil anos, mil anos ao lado dos escolhidos, que serão apenas as testemunhas da verdade. Segundo esse pensamento milenarista, após esse advento de Jesus, que durará mil anos, a Terra será transformada em um grande paraíso, onde todos (homens e animais) viverão em uma paz eterna (MARQUES, 2005, p. 220).
\end{abstract}

Existem duas formas possíveis de dizer o nome de Deus, que em hebraico é impronunciável, através da vocalização das consoantes que formam o tetragrama YHWH. A forma Yahweh derivou-se pela vocalização utilizando-se as vogais de adonai, "meu senhor", 
em hebraico. No entanto, havia variantes da forma de dizer, o que levou à outra forma de vocalização das consoantes, derivando o nome Yehowah, chegando até Jeová.

O caráter oriundo do nominalismo filosófico apregoa que a nomeação é condição de existência, ou seja, para que algo adquira sua existência "real" deve ser nomeado. Dessa forma, utilizam-se do tetragrama hebraico YHWH (Yahweh) como representação e demonstração da denominação de Deus como Jeová. Justificam essa denominação com apoio do pensamento nominalista, para o qual algo, para ser entendido, compreendido e aceito deve ser nomeado.

Essas noções podem ser contrapostas com a própria noção de signo propugnada por Saussure (2004). Para Saussure, a realidade só adquire existência para os homens ao ser nomeada. "Os signos são, assim, uma forma de apreender a realidade. Só percebemos no mundo o que a nossa língua nomeia" (FIORIN, 2003c, p. 55). E dessa forma, com apoio em Saussure (2004), tomaremos a concepção de signo como categorização, organização e interpretação do mundo, e que se opõe, por sua vez, à concepção de signo como mera nomenclatura aplicada a uma realidade preexistente, tal como propõe o nominalismo religioso.

A denominação "Testemunhas de Jeová" é determinada com base no relato bíblico de Isaias (43: 10-11):

\footnotetext{
10 "Vós sois as minhas testemunhas", é a pronunciação de Jeová, "sim, meu servo a quem escolhi, para que saibais e tenhais fé em mim, e para que entendais que eu sou o Mesmo. Antes de mim não foi formado nenhum Deus e depois de mim continuou a não haver nenhum. ${ }^{11}$ Eu é que sou Jeová, e além de mim não há salvador" (Isaias 43: 10-11) (TRADUÇÃO do Novo Mundo das Escrituras Sagradas, 1992, p. 939).
}

Testemunha de Jeová é, portanto, um nome descritivo, com a indicação de seu testemunho a respeito de Jeová, sua divindade e propósitos. 
As Testemunhas de Jeová baseiam as próprias crenças na Bíblia, tida como palavra de Deus, com a consideração de seus 66 livros como divinamente inspirados e historicamente corretos. Tomam o Novo Testamento por Escrituras Gregas Cristãs e o Velho Testamento por Escrituras Hebraicas. Fundamentadas e baseadas nesses dois escritos, afirmam interpretar a Bíblia literalmente, com exceção das situações em que o contexto indique se tratar de conteúdo figurativo ou simbólico. A tradução utilizada pelas TJ é a Tradução do Novo Mundo das Escrituras Sagradas, publicada pela Torre de Vigia.

O texto bíblico é interpretado e aprovado pelo Corpo Governante das Testemunhas de Jeová. Esse Corpo Governante é um órgão central das Testemunhas de Jeová formado por homens experientes, comumente designados anciãos e considerados "porta vozes" de Jeová a fim de difundir sua doutrina e ensinos bíblicos adequados. A interpretação do texto bíblico é publicada pela Sociedade Torre de Vigia de Bíblias e Tratados.

As Testemunhas de Jeová consideram praticar a única religião verdadeira (o primitivo Cristianismo) e, por isso, possuem uma configuração interdiscursiva, em que polemizam com relação às organizações religiosas consideradas biblicamente erradas em suas doutrinas e práticas nesse contexto.

Numa "Solene Profissão de Fé", em 30 de junho de 1968, o Papa Paulo VI declarou: "Cremos que, assim como o pão e o vinho consagrados pelo Senhor na Última Ceia se transformaram no Seu Corpo e no Seu Sangue, que haviam de ser oferecidos por nós na cruz, o pão e o vinho consagrados pelo sacerdote são transformados no Corpo e no Sangue de Cristo entronizado gloriosamente no céu, e Nós cremos que a misteriosa presença do Senhor, sob a aparência desses elementos, que aos nossos sentidos, parecem depois da Consagração iguais àquilo que eram antes, é uma presença verdadeira, real e substancial. . . . Esta transformação misteriosa é mui apropriadamente chamada pela Igreja de transubstanciação." (Official Catholic Teachings - Christ Our Lord, Wilmington, N.C., EUA; 1978, de Amanda G. Watlington, p. 411.) Concordam as Escrituras Sagradas com essa crença? [...]

Considere as expressões "isto é o meu corpo" e "isto é o meu sangue" à luz de outra linguagem vívida usada nas Escrituras. Jesus também disse: "Eu sou a luz do mundo", "eu sou a porta das ovelhas", "eu sou a verdadeira 
vide". (João $8: 12 ; 10: 7 ; 15: 1, B J$ ) Nenhuma dessas expressões deram a entender uma transformação milagrosa, não é fato?

Em 1 Coríntios 11:25 $(B J)$, o apóstolo Paulo escreveu concernente à Última Ceia e expressou as mesmas idéias em palavras ligeiramente diferentes. Em vez de citar a Jesus, como dizendo a respeito do cálice: "Bebei dele todos, pois isto é o meu sangue, o sangue da Aliança", verteu a frase do seguinte modo: "Este cálice é a nova Aliança em meu sangue." Ele certamente não queria dizer que o cálice de alguma forma miraculosa se transformou na nova aliança. Não é mais lógico concluir que o que se achava no cálice representava o sangue de Jesus, por meio do qual foi validada a nova aliança?

\section{Que queria Jesus dizer com o que falou em João 6:53-57?}

"Jesus lhes respondeu ...: 'Em verdade, em verdade, vos digo: se não comerdes a carne do Filho do Homem e não beberdes o seu sangue, não tereis a vida em vós. Quem come a minha carne e bebe o meu sangue tem a vida eterna e eu o ressuscitarei no último dia. Pois a minha carne é verdadeira comida e o meu sangue, verdadeira bebida. Quem come a minha carne e bebe o meu sangue permanece em mim e eu nele. Assim como o Pai, que vive, me enviou e eu vivo pelo Pai, também aquele que comer de mim viverá por mim." — - João 6:53-57, BJ.

Deve-se entender que isto significa que eles deviam literalmente comer a carne e beber o sangue de Jesus? Se assim fosse, Jesus estaria incentivando a violar a Lei que Deus havia dado a Israel por intermédio de Moisés. Essa Lei proibia o consumo de qualquer tipo de sangue. (Lev. 17:10-12) Ao invés de advogar tal coisa, Jesus falou fortemente contra violar quaisquer dos requisitos da Lei. (Mat. 5:17-19) Portanto, o que Jesus tinha em mente só podia ser comer e beber em sentido figurativo, por se exercer fé no valor do seu perfeito sacrifício humano. - Veja João $3: 16 ; 4: 14 ; 6: 35,40$ (RACIOCÍNIOS à base das Escrituras, 1989, p. 239-240).

O perfil cristão das Testemunhas de Jeová nos é apresentado no tratado de Estudo Bíblico intitulado: EM QUE CRÊEM as Testemunhas de Jeová? (1987, p. 2), para o qual ressaltamos a polêmica interdiscursiva explicitada:

Cremos que "toda a Escritura é inspirada por Deus e proveitosa". (2 Timóteo 3: 16) E, embora alguns tenham afirmado que realmente não somos cristãos, isto simplesmente não é verdade. Endossamos plenamente o testemunho do apóstolo Pedro a respeito de Jesus Cristo: "Não há outro nome debaixo do céu, que tenha sido dado entre os homens, pelo qual tenhamos de ser salvos." - Atos 4; 12. (grifo nosso)

A crença das Testemunhas de Jeová é baseada em um Deus único, Jeová, cuja força é o Espírito Santo. Acreditam que Deus é maior do que Jesus, ao tomar como base a seguinte passagem: "O Pai é maior do que eu" (Jo. 14: 28; 8: 28). Consideram a trindade uma invenção 
diabólica, devendo os fiéis ter como doutrina que Jesus teria sido criado por Deus, e a ele estaria subordinado. Rejeitam qualquer tipo de idolatria: do dinheiro, do sexo, das imagens dos santos e do exército (seus integrantes se recusam a prestar serviço militar). Sua alma é o seu sangue, por isso rejeitam o derramamento e a transfusão de sangue, o aborto e as práticas de serviço militar. Rejeitam a imortalidade da alma e apresentam uma concepção diferenciada de outros pensamentos e crenças religiosas no que diz respeito à vida após a morte, não acreditando em céu ou purgatório. De acordo com Marques (2005, p. 222), a crença das Testemunhas de Jeová se baseia em que:

todos dormiremos um sono profundo até o suposto juízo final, quando os maus não acordarão para fazer parte do paraíso. Esse suposto juízo final se dará no momento da ressurreição dos corpos, quando todos se levantarão de seus túmulos e ficarão diante de Jesus para serem julgados. Após esse julgamento, a residência permanente dos eleitos (Testemunhas de Jeová) será no paraíso ao lado de Deus, pois aquele que vencer, "dar-lhe ei de comer da árvore da vida, que está no paraíso de Deus" (MARQUES, 2005, p. 222).

Dessa forma, vemos que a concepção de vida após a morte para as TJ supõe que a ressurreição se dê no Reinado Milenar de Jesus, em que "milhões de mortos serão ressuscitados para a vida humana na Terra” (O QUE DEUS REQUER de Nós, 1996, p. 11). Em sua concepção, durante esse Reinado Milenar, os humanos fiéis se tornarão perfeitos e a Terra será transformada em um paraíso.

As Testemunhas de Jeová apresentam uma forte organização hierárquica e piramidal. A sede mundial das Testemunhas de Jeová está situada no Brooklyn, Nova York, EUA. Nela se encontra o corpo governante (grupo central de anciãos experientes que tem por função supervisionar a congregação mundial). O corpo governante é responsável pelo envio de representantes a várias regiões do globo, para que possam conferenciar com os representantes das filiais ou congêneres dessas regiões. Em cada uma dessas filiais, ou congêneres, encontrase uma comissão de filial, composta de três a sete membros, com a finalidade de supervisionar 
a obra nos países que se encontram sob sua jurisdição. Cada país ou região, tendo uma filial ou congênere que o supervisione, é dividido em distritos e esses, posteriormente, são divididos em circuitos, tendo cada um deles seu representante. Para cada circuito, há cerca de 20 congregações com a realização de duas assembléias anuais para cada circuito.

As congregações locais são denominadas de Salões do Reino, responsáveis pela proclamação das Boas Novas na comunidade. Para cada congregação, temos a presença de anciãos ou superintendentes que tomam a dianteira no ensino da congregação. Esses recebem a ajuda de servos ministeriais. As regiões destinadas para cada congregação são divididas em pequenos territórios designados a Testemunhas individuais, empenhadas na realização de sua missão de divulgação de porta em porta.

Também há a realização de assembléias e congressos ao longo do ano. Durante as assembléias e congressos, são reunidas muitas congregações para a realização de um programa especial de instrução bíblica. O batismo de novos discípulos também é parte do programa regular de realização dessas Assembléias.

As congregações das Testemunhas de Jeová organizam reuniões três vezes por semana. A Bíblia constitui a base de seus ensinamentos. As reuniões se iniciam e se finalizam com a realização de orações, em que também se verifica a presença de cânticos espirituais.

As reuniões são promovidas pela maior parte das congregações em espaços denominados de Salões do Reino, nos quais não se observam a presença de imagens, crucifixos, ou qualquer simbologia que possa demonstrar idolatria. 

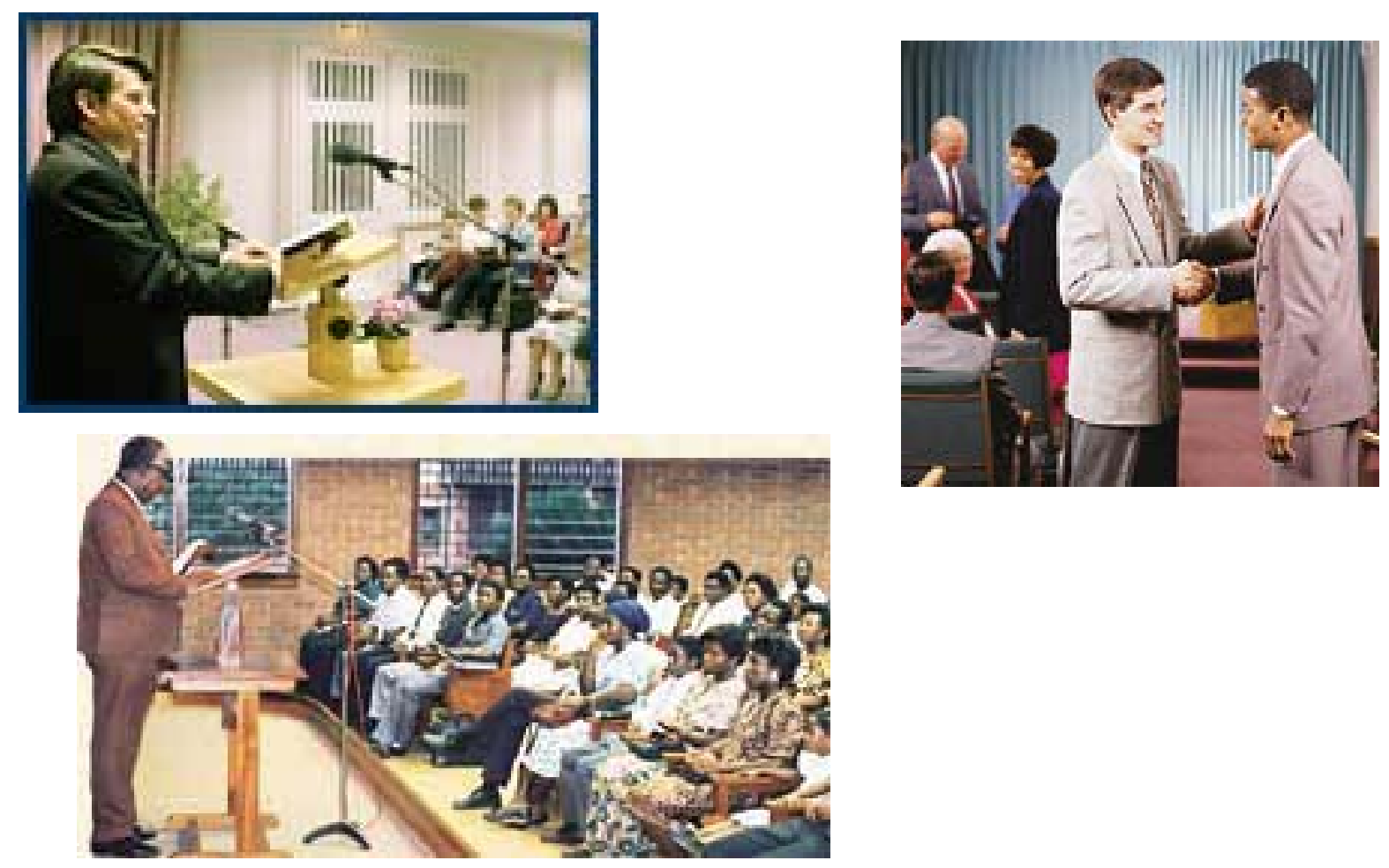

Ilustração 2 Reuniões congregacionais no Salão do reino das Testemunhas de Jeová. In: O QUE DEUS requer de nós. Sociedade Torre de Vigia de Bíblias e Tratados, 1996.

A denominação Salão do Reino foi sugerida por Joseph Rutherford, em 1935, que na época era o presidente da Sociedade Torre de Vigia de Bíblias e Tratados (Watch Tower Bible and Tract Society) dos Estados Unidos. Nessas reuniões não há a realização de ritos ou coleta, nem tampouco há a exigência de dízimo. As contribuições são voluntárias e devem ser realizadas nas caixas de contribuições dispostas em cada Salão do Reino.

Nas reuniões, verifica-se apenas a realização de palestras de estudo bíblico e associação cristã. Todas as três reuniões semanais se desenvolvem em cada congregação em torno de sessões de estudo da Bíblia orientadas pelas publicações editadas pela Sociedade Torre de Vigia de Bíblias e Tratados.

No primeiro encontro semanal, efetua-se a Reunião da escola do Ministério Teocrático. Esse encontro constitui um trabalho de educação bíblica que tem por objetivo promover a melhoria da habilidade oratória dos matriculados no que diz respeito à propagação bíblica. Os matriculados, incumbidos de realizar uma breve apresentação de um tópico 
previamente escolhido, recebem, então, conselhos de um instrutor com o objetivo de dar-lhes habilidades de leitura e da arte de falar em público.

A segunda reunião semanal corresponde à Reunião de Serviço e possui duração em torno de uma hora e quarenta e cinco minutos. Esse encontro, realizado por meio de discursos, palestras que envolvem a participação da assistência, demonstrações e entrevistas, é reservado aos testemunhos e informações diretamente relacionadas com o serviço de campo (pregação de porta em porta). Nele se consideram os métodos usados para dar testemunho e planos para futuras atividades.

A terceira reunião semanal compreende a reunião pública seguida do estudo da revista A Sentinela: Anunciando o Reino de Jeová e possui duração em torno de duas horas.

Observamos ainda, a realização da Reunião de Estudo do Livro de Congregação, realizada em grupos com cerca de quinze a vinte pessoas em casas particulares.

Anualmente, o Salão do Reino também é utilizado para a realização da reunião considerada a mais importante das Testemunhas de Jeová: a Comemoração da Morte de Cristo. A Comemoração da Morte de Cristo, que também recebe a denominação de Refeição Noturna do Senhor, ceia do Senhor, ou memorial, compreende a celebração em memória da morte e ressurreição de Cristo, que a despeito das semelhanças que pudesse apresentar com a celebração eucarististica católica, apresenta contornos bem diferenciados.

Definição: Uma refeição em comemoração da morte de Jesus Cristo; por conseguinte, uma comemoração de sua morte, a morte que tem tido efeitos de muito maior alcance do que a de qualquer outra pessoa. Este é o único evento que o Senhor Jesus Cristo ordenou que seus discípulos comemorassem. É também conhecida como a Ceia do Senhor, ou a Refeição Noturna do Senhor. - 1 Cor. 11:20. (RACIOCÍNIOS à base das Escrituras, 1989: 86).

Comemora-se, nessa reunião, o ato de amor praticado por Jesus, ao dar sua própria vida em prol da expiação dos pecados da humanidade. Para as Testemunhas, a Comemoração 
da Morte de Cristo substitui a celebração da Páscoa, que deixa de ter qualquer significado para os cristãos. Nessa comemoração anual, as Testemunhas de Jeová reúnem-se após o pôr do sol de 14 de Nisã, segundo o cálculo do calendário judaico. Nesse encontro, realizado no salão do Reino, ou em salões alugados, não são utilizadas decorações especiais ou quaisquer simbolismos. Apenas se verifica a presença de uma tribuna para o orador e uma mesa com os emblemas da Comemoração: o prato com o pão ázimo, ou não levedado, e uma taça com vinho.

Essa reunião tem uma duração média de uma hora e é constituída por uma palestra bíblica, na qual o orador recorda os eventos ocorridos na noite de 14 de Nisã de 33 EC, segundo a cronologia das Testemunhas de Jeová.

A Comemoração da Morte de Cristo começa com uma oração proferida pelo ancião local e em seguida o pão e o vinho são passados aos escolhidos. Cânticos e orações apropriados à ocasião tem lugar no início e no fim da celebração.

Merecem destaque nessa reunião o ato de amor de Cristo em prol da humanidade e a doutrina do resgate, considerada em seu pormenor.

A crença de que apenas 144.000 pessoas, ungidas ou escolhidas, serão ressuscitadas para uma vida imortal no céu, junto com Cristo, com o objetivo de reinarem sobre a Terra, também é descrita. Ao restante da humanidade, é apresentada a esperança de uma vida eterna na Terra, sob a liderança de um Reino governado por Jesus.

Os Salões Do Reino podem ainda ser utilizados em cerimônias de casamento, funerais, escolas de alfabetização, aprendizagem de línguas estrangeiras, linguagem de sinais e outras escolas relacionadas com a sua evangelização pública.

As Testemunhas de Jeová têm por missão pregar o "Reino das Testemunhas de Jeová" em todas as partes da Terra e a todas as pessoas. Fazem isso mediante a pregação de porta em 
porta, com o oferecimento de suas publicações de estudo bíblico. A página impressa (livros, brochuras e artigos) constutui o principal meio de divulgação de sua doutrina.

A difusão de sua mensagem é determinada principalmente pelas revistas de divulgação: A Sentinela - Anunciando o Reino de Jeová e Despertai!

Podemos destacar ainda como publicações: folhetos, tratados, brochuras e livros de estudos bíblicos. O número de publicações distribuídas, segundo dados extraídos da brochura: As Testemunhas de Jeová? Quem são? E o que crêem? (2000), chega a centenas de milhões de exemplares em cerca de 400 idiomas. Podemos mencionar ainda a divulgação por CDROM'S, tal como o Watchtower Library 2001 em português, que reúne todas as publicações das Testemunhas de Jeová de 1970 a 2001 e o seu web site oficial, www.watchtower.org, com informações disponíveis em 310 idiomas.

As Testemunhas de Jeová estão presentes em cerca de 230 países e somam cerca de 6.000.000 adeptos ao redor do mundo.

Segundo dados do Censo Demográfico do IBGE do ano de 2000, as Testemunhas de Jeová são o grupo mais numeroso dos neocristãos, reunindo uma média de 1,104. 879 milhões de fiéis distribuídos ao longo de todo o território nacional, com destaque para as capitais estaduais de São Paulo, Rio de Janeiro e Salvador. 


\section{CAPÍTULO II. Análise de textos de divulgação religiosa: enunciatário infanto-juvenil}

\section{Catecismo infanto-juvenil (Católico): Primeiro Catecismo da doutrina Cristã}

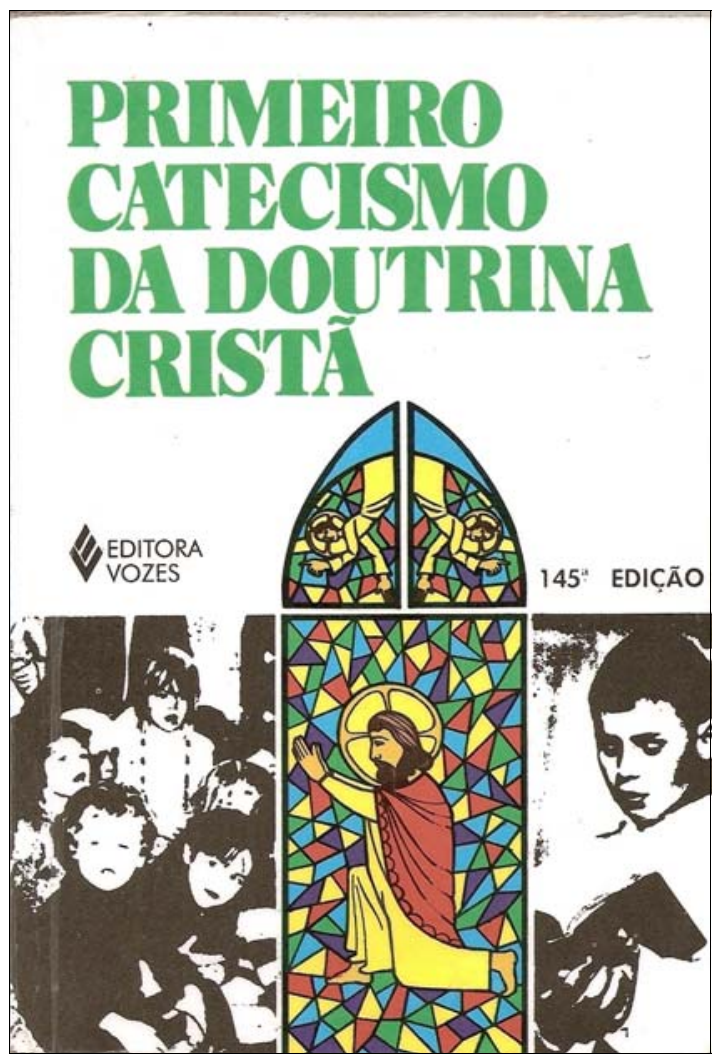

Ilustração 3 Capa do Primeiro Catecismo da Doutrina Cristã $\tilde{a}^{7}$

O objetivo deste capítulo é depreender mecanismos de construção do sentido de um texto de divulgação religiosa, o catecismo infanto-juvenil da Igreja Católica, designado Primeiro Catecismo da Doutrina Cristã.

O catecismo, ao constituir-se como discurso de divulgação religiosa, configura um gênero textual pertencente à esfera de circulação do discurso religioso e apresenta como elemento constitutivo de sua temática: o ensino dos símbolos da fé religiosa e da doutrina cristãs.

\footnotetext{
${ }^{7}$ SURIAN, Frei Carmelo. Primeiro Catecismo da Doutrina Cristã. 145 ed. São Paulo: Vozes, 2005.
} 
Ao pertencer à esfera de atividades institucionalizadas da prática religiosa católica, o catecismo configura-se como um instrumento autorizado que contém os elementos fundamentais da doutrina católica. Dirigido primordialmente às crianças e jovens, sem deixar de atender a população em geral, apresenta-se como um livro ou manual de instrução elementar da fé cristã, pautado pela exposição dos dogmas católicos, no qual se abre a possibilidade para que se possa conhecer aquilo que a Igreja professa, celebra, vive e prega em sua doutrina cotidiana.

A Palavra Revelada é instituída como fonte primeira desse discurso que tem por objetivo a manipulação do destinatário, para que este queira e deva entrar em conjunção com o ensinamento da Sagrada Escritura. O simulacro do dogma reforça o caráter de ensino da doutrina revelada e da regulação desse saber.

Vejamos como Discini (2005a, p. 395) explicita em que se constitui esse saber:

Trata-se de um saber sobre as coisas do reino de Deus; um saber apoiado em uma doutrina, vista como sugerida pelo Espírito Santo; um saber que diz respeito especificamente a temas consagrados pela fé católica, como a Tradição viva da Igreja e do Magistério autêntico, o que remonta à ação dos apóstolos, bem como à consolidação eufórica da "herança espiritual dos Padres, Santos e Santas da Igreja". Trata-se ainda de um saber que pressupõe a crença no mistério, o que corresponde a um "saber sobre o não saber". [...] O próprio catecismo é dado ao leitor como fonte imediata do saber. Tal catecismo é exposto como meio para o leitor construir a própria competência: saber ser católico. Lendo o catecismo, o leitor adquire um saber doutrinário. A performance do sujeito, segundo um dever-fazer, supõe um dever agir no mundo, de acordo com que o discurso propõe: dever propagar a fé ou, tal como está dito, promover uma "catequese renovada das fontes da fé" (DISCINI, 2005a, p. 395).

A forma composicional do gênero define-se pelo uso do texto instrucionalprogramador, na medida em que possibilita a aquisição de uma competência ao leitoraprendiz (catecúmeno) ${ }^{8}$, no caso, os atributos necessários para que ele se torne um sujeito

\footnotetext{
${ }^{8}$ Pessoa que se prepara e se instrui para que possa receber o batismo, neófito, noviço; e assim ser integrado a comunidade católica.
} 
religioso católico. Caracteriza-se pela utilização do tipo textual injuntivo, freqüentemente presente nessa modalidade de texto instrucional-programador.

Os textos injuntivos, embora se apresentem como uma seqüência de injunções, na verdade, transmitem um saber sobre como realizar alguma coisa, expõe um plano de ação para atingir determinado objetivo (FIORIN, 2005b, p. 13).

No que concerne à coerção genérica de sua exposição apresenta-se como um gênero inspirado na tradição e estruturado em torno de quatro pilares, dispostos em quatro partes, em correspondência com as leis fundamentais da vida em Cristo:

I. A Profissão de fé batismal (O Símbolo)

II. Os sacramentos da fé

III. A vida da fé

IV. A oração da vida da fé

Ainda no que concerne à coerção genérica, apresenta-se estruturado geralmente por meio do discurso direto, redigido na forma de perguntas e respostas. Outra característica desse gênero é a presença da iconografia religiosa, na qual, a imagem é utilizada na pregação evangélica, dado o dinamismo pretendido por esse discurso.

O Primeiro Catecismo da Doutrina Cristã confirma o gênero catecismo ao se oferecer como um manual de instrução elementar da fé cristã.

Ele apresenta como elemento constitutivo de sua temática: o ensino dos símbolos da fé religiosa e da doutrina católica. Dirigido fundamentalmente às crianças e à população em geral, o Primeiro Catecismo da Doutrina Cristã apresenta-se como um livro ou manual de instrução elementar da fé cristã, pautado pela exposição de dogmas de forma breve e direta. Ele é uma versão popular, remodelada e atualizada do tradicional Primeiro Catecismo da 
Doutrina Cristã, voltado à catequese para a primeira eucaristia, que busca oferecer, tal como o catecismo enuncia: "um texto completo e atraente quanto possível, mas barato, ao alcance da bolsa da maioria de nossos Vigários e fiéis" (SURIAN, 2005, p. 4).

No que concerne à estrutura composicional, determinada por meio da coerção genérica de sua exposição, para que possamos delinear o éthos do ator da enunciação e ao considerar cada trecho do catecismo como uma parte (unus), que abriga o todo (totus), devemos levar em conta a totalidade da qual fazem parte: a) a capa ; b) o título do livreto: Primeiro Catecismo da Doutrina Cristã ; c) o número da edição correspondente (145ª.ed.); d) o temário das lições; e) a oração inicial; f) o imprimatur (aprovação por parte da hierarquia da Igreja Católica, segundo a qual a obra se encontra livre de erros em matéria de doutrina e moral, e pode, portanto, ser impressa e lida pelos católicos.); g) a apresentação; h) o decreto da congregação dos Sacramentos Quam Singulari, aprovado pelo papa Pio X, citado na apresentação; i) as orações católicas (O sinal da cruz, Glória ao Pai, Credo, Pai-Nosso, Ave-Maria, SalveRainha); j) atos de fé, esperança, caridade e contrição; k) as 22 lições; 1) os apêndices (oração da comunidade cristã, celebração da Santa Missa, orações cotidianas, cânticos e o Ofício da Imaculada Conceição da Virgem Maria).

Contemplemos, inicialmente, a composição diagramática da capa do Primeiro Catecismo da Doutrina Cristã, retomada a seguir: 


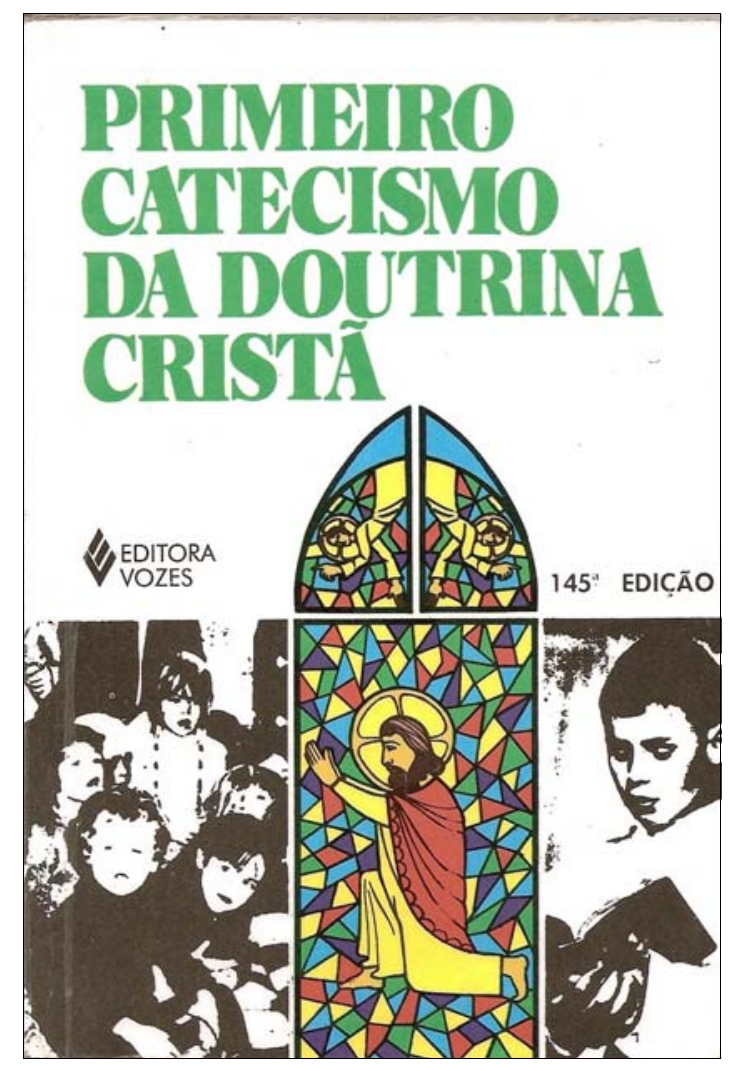

Ilustração 4 Capa do Primeiro Catecismo da Doutrina Cristã ${ }^{9}$

Ao observar atentamente a capa do catecismo, verificamos que ela se constitui por uma composição diagramática pautada pelo efeito de simplicidade em correspondência aos ideais didáticos de brevidade e clareza propostos pelo plano do conteúdo.

A própria materialidade da capa, determinada pelo tipo de papel e encadernação em brochura retoma o efeito de sentido de simplicidade determinados pela concisão, objetividade e clareza propostos no PC (plano do conteúdo). No plano de expressão (PE) da capa verificamos o título síntese do conteúdo disposto no alto, em letras de tamanho maior, em caixa alta e de cromatismo verde. Esse cromatismo perpassa toda a composição do catecismo, que é composto de três cores: preto, branco e verde. O título síntese, Primeiro Catecismo da Doutrina Cristã, retoma o objetivo do catecismo, pautado pela exposição da doutrina católica. Ele se apresenta, portanto, como o primeiro catecismo daqueles que se preparam para

\footnotetext{
${ }^{9}$ SURIAN, Frei Carmelo. Primeiro Catecismo da Doutrina Cristã. 145 ed. São Paulo: Vozes, 2005.
} 
catequese para a primeira comunhão. As crianças, principal público público-alvo, são reiteradas na própria capa. O corpo dos atores do enunciado é apresentado mediante a perspectiva enunciva dos olhares. No centro da página se figurativiza o símbolo católico do temas dos vitrais. O corpo do ator do enunciado, Cristo, é apresentado em posição central, em genuflexão e posição de oração. Os atores do enunciado, as crianças, figurativizadas pela gestualidade de seus movimentos, são modalizadas pelo saber, poder e crer dever entrar em conjunção com os valores propostos.

Tomamos como base a lição 13 "Jesus nos faz seus soldados" da qual se procederá à análise a seguir. Para que se possa ter idéia do suporte, a lição será reproduzida a seguir: 


\section{O ESPIRITO SANTO HABITA EM MIM}

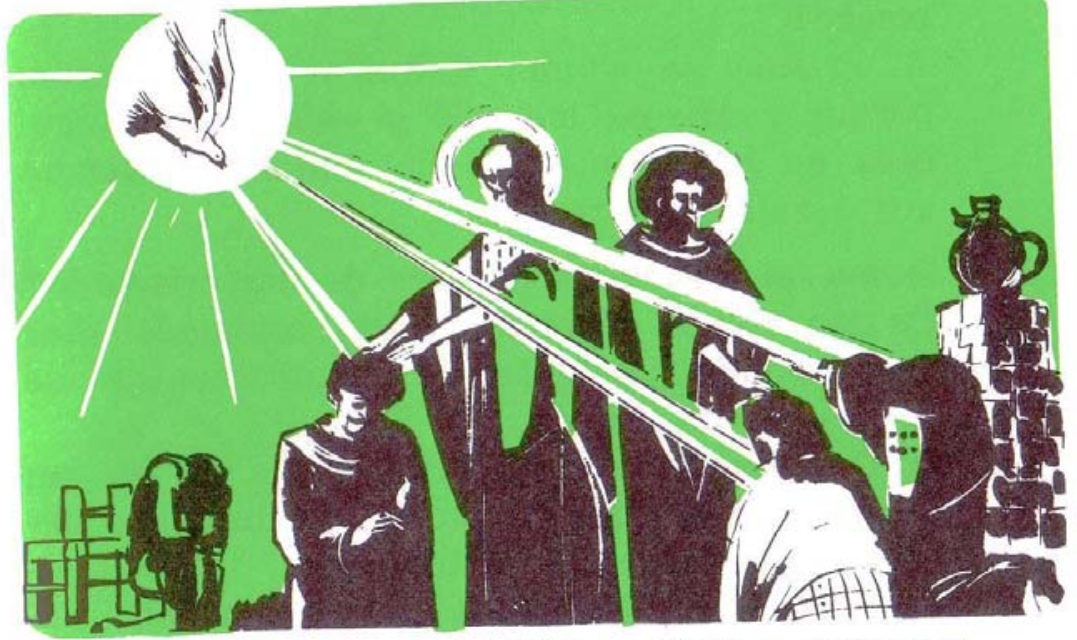

LUTAREI POR DEUS E PELA IGREJA

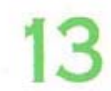

\section{JESUS NOS FAZ SEUS SOLDADOS}

$$
\text { (A: At 8,14. B: 282.) }
$$

118. Como é que Jesus nos faz Seus soldados? Jesus nos faz Seus soldados pela crisma.

* 119. Que é a crisma?

A crisma é o sacramento que nos dá o Espírito Santo, imprime na alma o caráter de soldado de Jesus Cristo e faz-nos perfeitos cristãos.

Ilustração 5 SURIAN, Frei Carmelo. Primeiro catecismo da Doutrina Cristã. 145 ed. São Paulo: Vozes, 2005. p. 47. 
* 120. Por que a crisma se chama também confirmação?

A crisma se chama também confirmação, porque confirma em nós a vida divina recebida no batismo e nos dá maior resistência aos assaltos da tentação.

* 121. Quais os principais deveres de um crismado? Os principais deveres de um crismado são: 1. Guardar fielmente os mandamentos de Deus e da Igreja.

$2^{\circ}$ Defender corajosamente a vida divina em seu coração dos perigos do mundo, do demônio e das más inclinações.

3. Amar a Santa Igreja e trabalhar por ela, sem respeito humano, como bom apóstolo.

122. Como devem preparar-se os que recebem a crisma em idade adulta?

Os que recebem a crisma em idade adulta devem preparar-se estudando bem a doutrina católica e fazendo uma boa confissão.

\section{NA LITURGIA}

Marcando-nos com a unção da cruz na testa, a crisma nos torna propriedade sagrada do Senhor. Por isso, em todas as missas de que participamos, juntamente com o ofertório da hóstia e do vinho, devemos renovar a oferta de nós mesmos ao serviço do Senhor e da Sua Santa Igreja.

\section{ORAÇÃO}

Ó Espírito Santo, vinde habitar em meu coração e tornaime um templo vivo, onde brilhe a Vossa glória. Amém.

\section{MISSÃO A CUMPRIR}

Indagar entre parentes e amigos sobre quem ainda não

Ilustração 6. SURIAN, Frei Carmelo. Primeiro catecismo da Doutrina Cristã. 145 ed. São Paulo: Vozes, 2005. p. 47-48. 
foi crismado e procurar levá-los à crisma.

DEVO GUARDAR PARA A VIDA

Sou templo vivo do Espírito Santo.

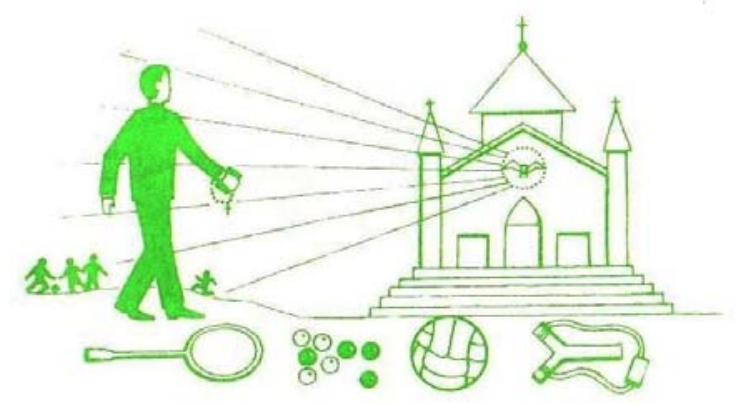

Ele foi crismado. Com a força do Espírito Santo, vence as tentações e não deixa de cumprir seus deveres de católico.

Ilustração 7. SURIAN, Frei Carmelo. Primeiro catecismo da Doutrina Cristã. 145 ed. São Paulo: Vozes, 2005. p. 49.

Assim, o catecismo considerado apresenta a seguinte estrutura em todas as lições que o constituem: a) texto baseado numa história bíblica, ilustrada nas cores verde, branco e preto, 
no cabeçalho; b) presença de dizeres que resumem a lição dispostos na moldura das ilustrações; c) número da lição correspondente; d) título da lição; e) como forma de auxílio aos catequistas e alunos, sugere a utilização dos seguintes índices (A-B) no início de cada lição.

\section{JESUS NOS FAZ SEUS SOLDADOS}

(ㅁ: At 8, 14. B. 282.).

A letra "A", posta entre parênteses logo após o número da lição e do título, corresponde à citação bíblica utilizada, representando, portanto, a cena fundadora que orienta a unidade recortada. No que diz respeito à letra "B", tem-se a referência da página em que se encontra a citação da História Bíblica a ser relatada aos alunos, presente na seguinte obra: HEUSSER, Bruno. História Sagrada do Antigo e do Novo Testamento. Petrópolis: Vozes, 2005.

A doutrina extraída da história apresenta-se disposta em perguntas e respostas. As questões assinaladas com asterisco (*) são consideradas as mais importantes. A estratégia básica das questões adquire a forma imperativa por meio da instituição de perguntas retóricas.

No que diz respeito à aplicação referente à vida litúrgica, interior e apostólica dos catecúmenos, observa-se a presença das seguintes seções, inseridas imediatamente após o texto pautado por perguntas e respostas: Na Liturgia; Oração; Missão a Cumprir e Devo Guardar Para a Vida. Logo após estas seções, encontram-se ilustrações didáticas, também referentes à vida litúrgica, interior e apostólica.

As imagens visuais de que se compõe o catecismo constituem-se plasticamente de uma grande simplicidade, o que corresponde, tanto ao efeito de sentido de simplicidade e clareza propostos pelo plano do conteúdo, quanto aos recursos gráficos ligados a gênese e circulação do texto. 
Ao concebermos o discurso como um conjunto de procedimentos argumentativos utilizados pelo enunciador para convencer o enunciatário, realizaremos, a seguir, a análise de alguns procedimentos argumentativos empregados pelo catecismo para fazer-crer e parecer verdadeiro seu enunciado.

\footnotetext{
A finalidade de todo ato de comunicação não é informar, mas persuadir o outro a aceitar o que está sendo comunicado. Por isso, o ato de comunicação é um complexo jogo de manipulação com vistas a fazer o interlocutário crer naquilo que se transmite. Por isso, ele é sempre persuasão (FIORIN, 2005a, p. 75).
}

O catecismo, construído essencialmente por meio do uso do imperativo, caracteriza-se como um enunciado pautado pela progressão lógica. A argumentação lógica, dada segundo a ordem da racionalidade, desenvolve-se no enunciado considerado mediante o vínculo causal: causa/ efeito. Esse tipo de argumentação, "em virtude da intervenção do vínculo causal”, visa, "a partir de um dado acontecimento, a aumentar ou a diminuir a crença na existência de uma causa que o explique ou de um efeito que dele resultaria" (PERELMAN; OLBRECHTSTYTECA, 2005, p. 300).

Ao desencadear uma operação fiduciária determinada pelo crer e pelo saber, apresenta sua constituição pautada por meio da conjunção de características do discurso religioso e pedagógico, dado que este último, de acordo com a definição de Orlandi (1996), também se constitui como um discurso autoritário.

A aprendizagem escolar, concebida como meio de transmissão de informações e conhecimentos, pode ser relacionada com a catequese como meio de ensino e propagação da doutrina religiosa católica.

O catequista, como mediador entre a voz divina e os catecúmenos, institui-se como detentor do saber, o responsável pela transmissão do saber sobre a divindade. O catecúmeno 
configura-se como um mero receptor (aluno), só ouve e assimila o conteúdo obtido por meio de uma comunicação dada em perguntas e respostas (perguntas retóricas).

De posse dessas noções e tomando como base o esquema de comunicação pedagógica desenvolvido por Orlandi (cf. 1996, p. 16), poderíamos caracterizar a comunicação catequética da seguinte forma:

\section{Processo de comunicação catequética}

\section{Quem?}

$\begin{array}{cc}\text { Enunciador } & \text { Enunciador } \\ \text { Primeiro } & \text { Segundo } \\ \downarrow & \downarrow \\ \text { Deus/ } & \text { Catequista } \\ \text { Jesus Cristo } & \end{array}$

\section{Ensina Como? O quê?}

Inculca
simulacros
Simulacro do dogma
Doutrina
Católica

\section{Para quem? Onde?}

$\begin{array}{cl}\text { imagem } & \text { Igreja } \\ \text { do aluno } & \\ \downarrow & \downarrow \\ \text { Catecúmeno } & \text { Aparelho } \\ & \text { ideológico }\end{array}$

A pergunta retórica constitui um dos principais recursos argumentativos utilizados por esse enunciado. A pergunta retórica constitui um modo indireto de dizer, elaborada não para que se obtenha a resposta, mas para fazer com que o interlocutor proceda à realização de determinadas asserções. Desse modo, contém em si implicitamente a resposta, misturando vozes, a que pergunta e a que responde.

Assim, temos um discurso pedagógico cujo modo de dizer é pautado pelo tom de voz professoral por meio da instituição das perguntas retóricas. O que contribui para a sua constituição como texto injuntivo pautado pela culminância da receita.

O catecismo considerado viabiliza um simulacro de efeito de polifonia por meio da ilusão de reversibilidade com a instauração de duas vozes no modo da mentira. O que o constitui, portanto, como um relato monofônico dotado de caráter de autoridade.

Esse simulacro institui o sujeito como presença mais próxima em relação ao enunciatário (leitor pressuposto) e em relação ao próprio enunciado. Além de fazer com que o leitor se aproxime do interlocutário (actante da enunciação delegado por meio de uma 
debreagem interna com a instauração do diálogo) para que este se veja obrigado a seguir uma orientação dada.

Assim, nesse discurso, a arquitetura do conhecimento não se institui como primordial, mas sim o ato perlocucional representado por meio do fazer-fazer, para que o sujeito possa agir de acordo com os preceitos da ordem religiosa considerada.

O estilo do catecismo é baseado em uma linguagem adaptada ao público a ele pressuposto como feixe de expectativas. Assim, apresenta fundamentalmente como leitores pressupostos, aqueles que devem se iniciar nos mistérios da fé e se preparar para receber o batismo, a confirmação e a eucaristia, sendo, por conseguinte, admitidos à Igreja. Esse catecismo, devido à estrutura que o constitui, apresenta-se adequado tanto ao leitor infantil, quanto ao adulto, desde que seja um leitor que queira, que seja instituído como expectativa daquele que quer ser domesticado, daquele que quer aprender tudo de maneira clara, que não deixa nada por dizer. Um leitor que quer um conteúdo revestido de facilitação, revestido de explicitação, que não deixe dúvidas. Um conteúdo que quer parecer transparente.

Desse modo, a cenografia considerada para análise confirma o gênero catecismo, apresentando-se como um tipo textual injuntivo com a exposição de prescrições a serem realizadas a fim de se atingir um determinado objetivo: a manutenção da comunhão com a comunidade da Igreja Católica.

\section{1 “Jesus nos Faz seus Soldados": Análise Semiótica}

Assim sendo, o texto instrucional recortado, pertence à esfera de circulação do discurso de divulgação religiosa, cujo gênero examinado é o catecismo. Ao materializar o 
gênero "catecismo", caracteriza-se pela utilização do tipo textual injuntivo, dado por meio da culminância da receita. Na medida em que possibilita a aquisição de uma competência, no caso os atributos necessários para que o indivíduo se torne um sujeito religioso cristão da totalidade representada pela esfera de circulação do discurso religioso católico, configura um modo de presença no mundo. O éthos não mais do gênero "gênero catecismo", mas o éthos, o estilo de uma cenografia específica, caracterizado por um modo de enunciação particular.

Partindo do princípio de que o unus (unidade integral) remete ao totus (totalidade integral), realizaremos a análise de uma lição do referido catecismo: "Jesus nos faz seus soldados". Inicialmente, trataremos das alusões intertextuais a que o catecismo faz referência, para em seguida nos ocupar da análise semiótica de "Jesus nos faz seus soldados", cujo sentido será desbastado por meio da ferramenta teórico-metodológica representada pelo percurso gerativo do sentido.

Para que possamos realizar a análise dos textos, aos quais o enunciado da lição catequética considerada faz referência, devemos levar em conta a noção de intertextualidade. A intertextualidade refere-se às relações de citatividade, aos diferentes modos de retomada intertextual, ou seja, aos diferentes modos de se recuperar um texto alheio dentro de um determinado texto e de como ele se torna um texto próprio.

Quando um texto se vale de outro já existente, ele pode referir-se a ele de maneira implícita ou explícita. Os processos de intertextualidade: citação, alusão e estilização, dos quais se constituem as relações intertextuais, configuram exemplos de heterogeneidade mostrada.

A "heterogeneidade mostrada" corresponde à presença localizável de um discurso outro no fio do discurso. Distinguem-se as formas não-marcadas dessa heterogeneidade e suas formas marcadas (ou explícitas). O coenunciador identifica as formas não-marcadas (discurso indireto livre, alusões, ironia, pastiche...) combinando em proporções variáveis a seleção de índices textuais ou para-textuais diversos e ativação de sua cultura pessoal. As formas marcadas, ao contrário, são assinaladas de maneira 
unívoca; pode tratar-se de um discurso direto ou indireto, de aspas, mas também de glosas que indicam uma não-coincidência do enunciador com o que ele diz (modalização autonímica) (CHARAUDEAU; MAINGUENEAU, 2004, p. 261).

A lição catequética apresenta, portanto, a utilização de uma forma mostrada e marcada (explícita) de heterogeneidade ao representar os textos aos quais faz referência por meio das letras (A-B) iniciando a lição considerada.

JESUS NOS FAZ SEUS SOLDADOS

(ㅁ: At 8, 14. B: 282.) (grifo nosso)

Dessa maneira, observamos que o catecismo faz referência a outros textos, por meio do procedimento intertextual da alusão.

Outro processo de relação intertextual é a alusão. Neste não se citam as palavras (todas ou quase todas), mas reproduzem-se as construções sintáticas em que certas figuras são substituídas por outras, sendo que todas mantêm relações hiperonímias com o mesmo hiperônimo ou são figurativizações do mesmo tema (FIORIN, 2003b, p. 31).

Assim, tomando como base as noções compreendidas, definiremos a noção de variante intertextual. Para que possamos realizar o estabelecimento dessa noção, tomemos como base, inicialmente, o conceito de isotopia, tal como nos apresenta Bertrand (2003, p. 420-421):

Isotopia: Recorrência de um elemento semântico no desenvolvimento sintagmático de um enunciado, que produz um efeito de continuidade e permanência de um efeito de sentido ao longo da cadeia do discurso. Diferentemente do campo lexical (conjunto de lexemas ligados a um mesmo universo de experiência) e do campo semântico (conjunto de lexemas dotados de uma organização estrutural comum), a isotopia não tem por horizonte a palavra, mas o discurso. Ela pode assim referir-se ao estabelecimento de um universo figurativo (isotopia de atores, tempo e espaço), mas também à tematização desse universo (isotopias abstratas, 
temáticas, axiológicas), e sobretudo à hierarquia entre as isotopias de leitura (por identificação de um núcleo isotopante que rege as isotopias de nível inferior). Conectando as isotopias, as figuras de retórica (metáfora, metonímia, etc.) instalam a coexistência extensiva e eventualmente competitiva de dois ou mais planos de significação simultaneamente oferecidos à interpretação (BERTRAND, 2003, p. 420-421).

Tomamos a noção de isotopia como reiteração e recorrência de traços semânticos que determinam a leitura de um dado texto.

Podemos assim, com apoio em Discini (2004a, p. 31), definir a noção de variante intertextual da seguinte forma:

A isotopia determina a leitura, ou uma virtualidade finita de leituras de um texto. A variante intertextual será, portanto, em princípio, um texto biisotópico, pois admite a primeira leitura, que é a do texto em si, e a segunda que é a do texto relacionado ao texto base, ou vice-versa (DISCINI, 2004a, p. 31).

O discurso fundador (Palavra Revelada) aparece como fonte primeira a esse discurso, como "ponto de referência nessa rede intertextual" (DISCINI, 2004a, p. 25) representada por meio do relato bíblico de Atos dos Apóstolos $(8,14)$, de sua retomada parafrástica e da lição catequética dogmática.

Desse modo, tanto o enunciado do catecismo, quanto a retomada parafrástica do relato bíblico de Atos presente em História Sagrada, constituem-se como "captação" do texto fonte e instituem, com relação a ele, mecanismos de enunciação particular.

O conceito de "captação" é constitutivo dos fenômenos de heterogeneidade mostrada, "quando há "captação", a imitação incide sobre a estrutura explorada" (MAINGUENEAU, 1997, p. 102). Ao partirmos dessas considerações, vejamos como se constituem os procedimentos de "captação" em cada uma das variantes intertextuais cotejadas.

Os apóstolos, que estavam em Jerusalém, tendo ouvido que a Samaria acolhera a palavra de Deus, enviaram-lhes Pedro e João. Estes, descendo até lá, oraram por eles, a fim de que recebessem o Espírito Santo. Pois não tinha 
descido ainda sobre nenhum deles, mas somente haviam sido batizados em nome do Senhor. Então começaram a impor-lhes as mãos e eles recebiam o Espírito Santo (At, 8,14) (BÍBLIA de Jerusalém, 2004, p. 1915).

O relato bíblico de Atos dos Apóstolos $(8,14)$ constitui-se como fonte primeira e fiadora do discurso do catecismo, graças ao caráter de autoridade e veracidade instituído por esse discurso. Constitui o que Maingueneau (1997, p. 100-101) denomina "citação de autoridade":

Geralmente, tratam-se de enunciados já conhecidos por uma coletividade, que gozam o privilégio da intangibilidade: por essência não podem ser resumidos nem reformulados, constituem a própria Palavra, captada em sua fonte (MAINGUENEAU, 1997, p. 100-101).

A presença de sua referência por meio da letra "A”, iniciando a lição, institui o caráter de legitimação a esse discurso e à doutrina nele relatada.

A citação de autoridade, ao apresentar a instituição do sacramento da crisma pelos Apóstolos (Pedro e João), institui e confirma o caráter da crisma como sinal divino concedido por Cristo e intermediado pela força do Espírito Santo, o que reforça o caráter da doutrina Revelada.

Atos dos Apóstolos, presente no Novo Testamento, apresenta-se como um livro histórico de autoria do evangelista Lucas. O gênero desse discurso apresenta-se como uma narrativa de atos ou práticas, tal como a literatura helenística reconhecia as narrativas de atos ou práticas de pessoas famosas, como Aníbal e Alexandre o grande. A narrativa dos Atos apostólicos, de estilo lacônico e linguagem polida do narrador, apresenta o caráter de testemunho e conclamação da fé.

Vejamos a retomada parafrástica de Atos presente em HEUSSER, Frei Bruno. História Sagrada do Antigo e do Novo Testamento. 65 ed. São Paulo: Vozes, 2003. 


\section{Os apóstolos conferem o Sacramento da Crisma.}

- Logo que o santo diácono viu confirmada a sua obra, apressou-se em relatá-la aos apóstolos, que se encheram de júbilo. Como Felipe não tinha o poder de impor as mãos aos recém batizados, vieram Pedro e João a Samaria, para administrar-lhes o sacramento da confirmação ou crisma. Os apóstolos lhes impuseram as mãos, a fim de que recebessem o Espírito Santo.

Nestes primeiros tempos da Igreja nascente, Deus ajuntava ordinariamente às influências invisíveis do Espírito Santo os dons sensíveis, que se manifestavam pela profecia e pelo conhecimento das línguas (HEUSSER, 2003, p. 282).

O texto presente em História Sagrada constitui-se como um fazer parafrástico do texto fundador.

A paráfrase resulta de um acordo entre a enunciação enunciada e o enunciado enunciado, na medida em que o texto-base, implícito na enunciação, é assimilado pelo enunciado da variante intertextual. Esse acordo resolve-se, portanto, na captação dos níveis fundamental, narrativo e discursivo do texto base (DISCINI, 2004a, p. 72).

Desse modo, o texto cotejado em História Sagrada, sendo realização parafrástica do relato bíblico de Atos, ao imitar e captar o texto de referência imprime a este uma visão própria, que remete a um modo diferente de presença do sujeito. Construído por meio de um estilo mais simples, apresenta uma linguagem mais aproximativa do público atual, uma linguagem constitutiva de um recurso didático para melhor assimilação da doutrina revelada.

Após termos tratado das alusões intertextuais a que o catecismo faz referência, nos ocuparemos da análise semiótica da unidade recortada: "Jesus nos faz seus soldados". Partindo do princípio de que o sentido dos textos não é algo exterior e apriorístico ao signo, mas resultante da reunião dos dois planos compreendidos na linguagem (o plano do conteúdo e o plano da expressão); levando em consideração a ideologia em que se fundamenta tal discurso, buscar-se-á, no recorte analítico proposto, analisar semioticamente a construção do sentido dado na lição "Jesus nos faz seus Soldados", presente no Primeiro Catecismo da Doutrina Cristã. 
Com apoio no percurso gerativo de significação, procuraremos estabelecer, inicialmente, a oposição semântica fundamental, representativa da organização mínima do texto. Para tanto, tomemos como base o seguinte segmento recortado do texto analisado:

*121. Quais os principais deveres de um crismado?

Os principais deveres de um crismado são:

$1^{\circ}$. Guardar fielmente os mandamentos de Deus e da Igreja.

$2^{\circ}$. Defender corajosamente a vida divina em seu coração dos perigos do mundo, do demônio e das más inclinações.

$3^{\circ}$. Amar a Santa Igreja e trabalhar por ela, sem respeito humano, como bom apóstolo (SURIAN, 2005, p. 48).

Podemos, então, depreender as relações fundamentais estabelecidas por meio do quadrado semiótico. A direção das setas apresenta a orientação fundamental seguida no enunciado do catecismo:

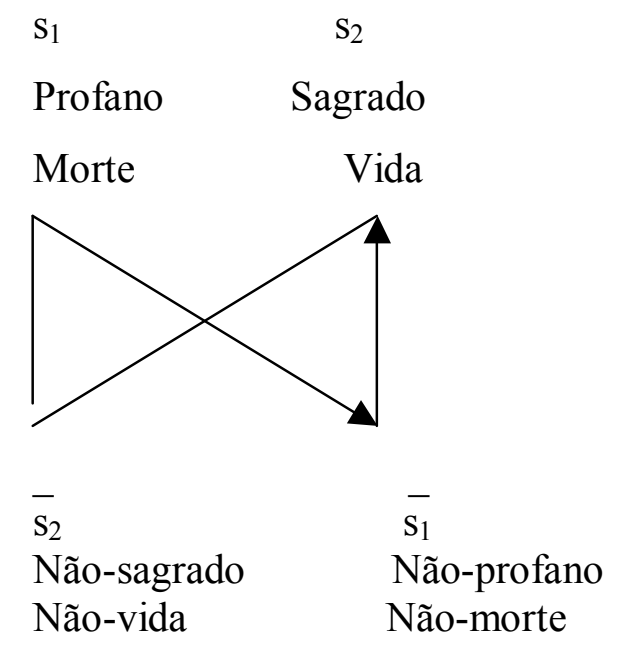

Ao analisar o quadrado tal como exposto, podemos perceber que a oposição semântica fundamental é estabelecida entre os termos contrários (profano e sagrado) e contraditórios (não-sagrado e não-profano), que se relacionam, por sua vez, às categorias de vida e morte. $\mathrm{O}$ "profano" é representada pelo domínio das pulsões individuais e naturais do indivíduo e o 
“sagrado" pelo domínio social ritualizado por meio da prática religiosa representada pela instituição do sacramento da crisma.

Assim, os termos do quadrado são axiologizados dentro da ideologia católica da seguinte forma: os termos (sagrado e não-profano) são axiologizados com valores eufóricos e os termos (profano e não-sagrado) com valores disfóricos. De tal maneira, que se tem a seguinte relação entre os termos do quadrado: o termo "sagrado" aparece como uma prescrição católica e, portanto como uma injunção positiva; "profano" aparece como uma interdição (injunção negativa), "não-profano" aparece como uma não-interdição (não injunção negativa) e "não-sagrado" como uma relação não prescrita (não injunção positiva).

Esse modo específico de axiologizar valores corresponde aos preceitos de uma determinada formação ideológica, no caso, os valores propugnados pela ideologia religiosa católica e que serão materializados no nível discursivo do percurso gerativo do sentido. A ideologia católica faz-se presente como feixe de valores prescritos por sua doutrina por meio da apreensão e adesão do catecúmeno aos conteúdos da fé, da moral e das práticas cristãs. Os valores não prescritos e, conseqüentemente, transgressores da crença e moral católicas e de tendência disforizante constituem aqueles que se puserem a contestá-la, ou que ao deixarem de cumprir os seus deveres de católico se deixem levar por tentações mundanas.

Ao tomarmos a narratividade como elemento "componente de todos os textos", vista como "uma transformação situada entre dois estados sucessivos e diferentes" (FIORIN, 2005, p. 27), propomos descrever os mecanismos de estruturação sintática e organização semântica do enunciado considerado para análise.

No que concerne ao Programa Narrativo (PN), "sintagma elementar da sintaxe narrativa", constituído de "um enunciado de fazer que rege um enunciado de estado" (BARROS, 2002, p. 31), observamos a transformação principal, operacionalizada neste 
discurso como a ação de um sujeito sobre outro, para que este último possa manter-se em conjunção com o objeto-valor "graça divina".

Assim, o programa narrativo de base que rege este discurso pode ser descrito como se segue:

\section{PN de base:}

$\mathrm{S}_{1} \rightarrow \mathrm{S}_{2} \cap \mathrm{O}_{\mathrm{v}}$

$\mathrm{S}_{1}=$ catequista

$\mathrm{S}_{2}=$ catecúmeno

$\mathrm{O}_{\mathrm{v}}=$ graça divina

No catecismo, as respostas vão sendo dadas em lições distintas. Cada lição se remete à posterior e vice-versa. De tal modo que, os quatro pilares em que se estrutura a doutrina católica vão-se erigindo: I. A profissão de fé batismal; II. Os sacramentos da fé; III. A vida da fé; IV. A oração na vida da fé.

Vejamos como esses pilares se estruturam no enunciado do catecismo considerado:

I. A profissão de fé batismal: síntese da fé professada pela Igreja católica "lex credenti".

Lição1: O sinal da salvação;

Lição 2: Jesus nos revela o Pai;

Lição 3: No batismo de Jesus, Se revela a Santíssima Trindade;

Lição 4: Jesus prometido como Salvador;

Lição 5: Jesus vem nos ensinar a viver como filhos de Deus;

Lição 6: Jesus nos ama até a morte;

Lição 21: Jesus nos ama pela Igreja; 
Lição 22: Como amar a Jesus.

II. Os sacramentos da fé: celebração do mistério cristão "lex celebranti".

Lição 11: Jesus nos dá os sacramentos;

Lição 12: Jesus nos dá Sua vida, nos faz seus irmãos;

Lição 13: Jesus nos faz Seus soldados;

Lição 14: Jesus vive conosco;

Lição 15: Sejamos dignos de Jesus;

Lição 16: O Sacrifício de Jesus;

Lição 17: Jesus nos dá o perdão pelo Pai celeste;

Lição 18: Jesus alívio dos doentes;

Lição 19: Jesus conosco pelos padres;

Lição 20: Jesus une para sempre os casados.

III. A vida da fé: fidelidade á fé professada e celebrada "lex vivendi".

Lição 8: Jesus nos mostra a vontade do Pai;

Lição 9: Jesus nos fala da maldade do pecado;

Lição 10: Jesus nos fala da outra vida.

IV. A oração na vida da fé: síntese da vida de oração "lex orandi".

Lição 7: Jesus nos ensina a rezar. 
Observamos que o PN de base que rege esse enunciado apresenta o Sujeito $S_{1}$ fazendo com que $\mathrm{S}_{2}$ permaneça em conjunção com o $\mathrm{O}_{\mathrm{v}}$ "graça divina", cujo investimento semântico e atribuição já teriam sido efetuados num $\mathrm{PN}$ de base, subentendido, que remonta à lição anterior.

O PN de base subentendido, a que nos referimos, remonta à lição 12 “Jesus nos dá sua vida, nos faz seus irmãos", imediatamente anterior à lição 13 "Jesus nos faz seus soldados" considerada para análise.

Nesse PN prévio, já se teria atribuído ao actante sujeito o $\mathrm{O}_{\mathrm{v}}$ "graça divina" por meio da instituição do sacramento do batismo.

Dentro da ideologia católica, são sete os sacramentos: Batismo, Confirmação, Eucaristia, Penitência, Unção dos Enfermos, Ordem e Matrimônio.

Aqui, nos ateremos apenas aos sacramentos de iniciação cristã do Batismo e da Confirmação (crisma), por meio dos quais "são lançados os fundamentos de toda a vida cristã” (JOÃO PAULO II, 2000, p. 339).

Nesse PN prévio, tem-se a instauração do sacramento do Batismo, porta de acesso a todos os demais sacramentos. Por meio da instituição do sacramento do batismo, dentro da ideologia católica, os fiéis se instituem como irmãos de Jesus Cristo, libertam-se de seus pecados, se tornam membros da Igreja Católica e participantes de sua missão apostólica.

Vejamos como esse PN prévio aparece configurado na referida lição “Jesus nos dá sua vida, nos faz seus irmãos":

110. Como é que Jesus nos dá a Sua vida e nos faz seus irmãos? Jesus nos dá a Sua vida e nos faz seus irmãos pelo batismo.

*111. Que é o batismo?

O batismo é o sacramento que Nosso Senhor Jesus Cristo instituiu para nos tirar o pecado original, dar-nos a vida da graça, e fazer-nos cristãos, filhos de Deus e da Igreja.

112. Quem não é batizado pode receber outro sacramento? 
Não. Quem não é batizado não pode receber nenhum outro sacramento, porque ainda não é filho de Deus e da Igreja (SURIAN, 2005, p. 44-45).

Desse modo, por meio desse PN prévio, o catecúmeno já teria sido cognitiva e pragmaticamente premiado por meio da recepção do dom da "graça" no batismo. Cabe ao PN de base da lição 13 a atribuição de poder e saber para que o sujeito continue em conjunção com o $\mathrm{O}_{v}$ alcançado.

De acordo com a ideologia católica, uma vez nascido para a vida e graça por meio do batismo, os cristãos, por meio da administração do sacramento da crisma, são fortalecidos pelo Espírito Santo, o que os torna capazes de defender a sua fé e se valer contra as tentações mundanas.

Tomemos inicialmente o esquema narrativo como modelo hipotético de estruturação geral da narrativa. O esquema narrativo "cumpre o papel de ser a organização de referência, a partir da qual são examinadas as expansões e variações e estabelecidas as comparações entre as narrativas" (BARROS, 2005, p. 36). Pensamos no esquema narrativo para a depreensão da unidade entre as partes de que se compõe a referida lição catequética: a) texto da lição pautado por perguntas e respostas; b) seções: Na Liturgia; Oração; Missão a Cumprir e Devo Guardar Para a Vida; c) ilustrações didáticas referentes à vida litúrgica, interior e apostólica.

Esquematizamos, a seguir, o esquema narrativo geral, para demonstrar como a lição se organiza em uma única narrativa. Teremos assim uma visão de conjunto a fim de que possamos entender melhor narrativamente o papel que cada uma das seções representa.

\section{Esquema narrativo}

\section{Percurso do destinador-manipulador}

Contrato entre o enunciador do catecismo e o enunciatário (catecúmeno), para que este adquira a competência esperada com o seu comprometimento com os ideais propostos pela 
doutrina católica, levando-o à conjunção com o $\mathrm{O}_{\mathrm{V}}$ representado pelos princípios da fé, da prática e moral católicas.

\section{$\underline{\text { Percurso do Sujeito }}$}

O catecúmeno cumpre adequadamente seu contrato, não deixando de cumprir seus deveres de católico.

\section{$\underline{\text { Percurso do destinador-julgador }}$}

A sanção é positiva, com o julgamento da conduta do sujeito, reconhecido e considerado cumpridor do contrato.

No que concerne à narratividade imanente a esse discurso, vê-se que sua constituição é baseada na instalação das seguintes seqüências narrativas ${ }^{10}$, tal como se segue.

\section{$\mathrm{SN}_{1}=$ Da Enunciação Enunciada}

$$
\begin{aligned}
& \mathrm{S}_{1} \rightarrow\left(\mathrm{S}_{2} \cup \mathrm{O}_{\mathrm{v}}\right) \rightarrow\left(\mathrm{S}_{2} \cap \mathrm{O}_{\mathrm{v}}\right) \\
& \mathrm{S}_{1}=\text { Jesus Cristo } \\
& \mathrm{S}_{2}=\text { Cristão } \\
& \mathrm{O}_{\mathrm{v}}=\text { "graça divina" }
\end{aligned}
$$

${ }^{10}$ Os Programas Narrativos se encontram reunidos em Seqüências Narrativas (SN) na verticalidade da diagramação da página. 


\section{$1^{\mathrm{a}} . \mathrm{SN}$}

\section{Manipulação}

$\mathrm{D}_{1} \rightarrow \mathrm{D}_{2} \cap \mathrm{O}_{\mathrm{m}}$

$\mathrm{D}_{1}=$ Jesus Cristo / Espírito Santo

$\mathrm{D}_{2}=$ Cristão

$\mathrm{O}_{\mathrm{m}}=$ poder ter o poder (força) para resistir aos assaltos da tentação

\section{Competência}

PN de aquisição de competência.

(O Espírito Santo confere o sacramento da crisma e imprime na alma do cristão "o caráter de soldado de Jesus cristo".)

$$
\begin{aligned}
& \mathrm{S}_{1} \rightarrow\left(\mathrm{S}_{2} \cup \mathrm{O}_{\mathrm{m}}\right) \rightarrow\left(\mathrm{S}_{2} \cap \mathrm{O}_{\mathrm{m}}\right) \\
& \mathrm{S}_{1}=\text { cristão } \\
& \mathrm{S}_{2}=\text { cristão } \\
& \mathrm{O}_{\mathrm{m}}=\text { querer e saber agir como cristão católico. }
\end{aligned}
$$

\section{Performance}

$\mathrm{S}_{1} \rightarrow\left(\mathrm{S}_{2} \cup \mathrm{O}_{\mathrm{v}}\right) \rightarrow\left(\mathrm{S}_{2} \cap \mathrm{O}_{\mathrm{v}}\right)$

$\mathrm{S}_{1}=$ Espírito Santo

$\mathrm{S}_{2}=$ Cristão

$\mathrm{O}_{\mathrm{v}}=$ querer manter a conjunção com a "graça divina".

A Performance se realiza: O crismado "com a força do Espírito santo, vence as tentações e não deixa de cumprir seus deveres de católico" (SURIAN, 2005, p. 49). 
Sanção cognitiva: Reconhecimento

Sanção pragmática: Recepção do sacramento da crisma.

\section{$\mathrm{SN}_{2}=$ Enunciação como construção do enunciado}

$$
\begin{aligned}
& \mathrm{F} \rightarrow\left[\mathrm{S}_{1} \rightarrow\left(\mathrm{S}_{2} \cap \mathrm{O}_{\mathrm{v}} \text { enunciado }\right)\right] \\
& \mathrm{S}_{1}=\text { Palavra Revelada } \\
& \mathrm{S}_{2}=\text { Sujeito enunciador }
\end{aligned}
$$

\section{Manipulação}

$\mathrm{S}_{1}$<smiles>C=CC</smiles>

Palavra

Revelada

Valores

Ideológicos

Católicos

Competência

Sabe

$\mathrm{S}_{2}$<smiles>CCCCC</smiles>

Escrever o catecismo

Pode

\section{Performance}

$\mathrm{S}_{2}$ constrói o $\mathrm{O}_{\mathrm{v}}$ enunciado 


\section{Sanção}

$\mathrm{S}_{2}$ é reconhecido

\section{$\mathrm{SN}_{3}=$ programa narrativo de base (construção de significado pelo enunciatário por intermédio da enunciação)}

$\mathrm{F} \rightarrow\left[\mathrm{S}_{1} \rightarrow\left(\mathrm{S}_{2} \cap \mathrm{O}_{\mathrm{v}}\right.\right.$ "graça divina" $\left.)\right]$

$\mathrm{F}=$ fazer-saber

Doutrinar nos princípios da fé, moral e prática católicas

$\mathrm{S}_{1}=$ enunciador do catecismo

$\mathrm{S}_{2}=$ catecúmeno

$\mathrm{O}_{\mathrm{v}}=$ "graça divina" (aceitação dos princípios da fé, moral e prática católicas).

O catecismo, ao se realizar como um texto instrucional, configura-se como um texto injuntivo, que apresenta a prescrição a ser realizada na ordem do parecer, como uma espécie de "receita a ser seguida", para que se possa manter a conjunção com o objeto valor "graça divina".

\section{PN de base comum ao enunciado e à enunciação}

$$
\begin{array}{ll}
\mathrm{F} \rightarrow\left[\mathrm{S}_{1} \rightarrow\left(\mathrm{S}_{2} \cap \mathrm{O}_{\mathrm{v}} \text { "graça divina" }\right)\right] & \\
\mathrm{S}_{1}=\text { Jesus Cristo / Espírito Santo } & \zeta \text { Enunciado } \\
\mathrm{S}_{2}=\text { Cristão } & \succ \text { Enunciação } \\
\mathrm{S}_{1}=\text { enunciador } & \\
\mathrm{S}_{2}=\text { enunciatário } &
\end{array}
$$


No que concerne à narratividade imanente à primeira seqüência narrativa $\left(\mathrm{SN}_{1}\right)$, tida como a da enunciação enunciada, com a projeção dos actantes da enunciação no interior do enunciado, observamos, inicialmente, um PN de manutenção de estado, no qual $\mathrm{S}_{1}$ deve fazer com que $\mathrm{S}_{2}$ permaneça em conjunção com o $\mathrm{O}_{v}$ "graça divina".

Observamos, por meio da lição catequética, a narrativa da transformação de estados do sujeito cristão, que inicialmente disjunto do $\mathrm{O}_{\mathrm{m}}$ poder ter o poder (força) para resistir aos assaltos da tentação, busca a sua conjunção. Essa conjunção com o objeto de valor modal, representado pelo poder e força, dá-se por meio do programa narrativo de doação de competência realizado pela figura de Jesus Cristo, por meio da intermediação do Espírito Santo. A instituição do sacramento da crisma ao imprimir na alma do cristão "o caráter de soldado de Jesus Cristo", confere o poder e força necessários para que este possa se tornar um verdadeiro cristão. Com isso, a performance se realiza: "Ele foi crismado. Com a força do Espírito Santo, vence as tentações e não deixa de cumprir seus deveres de católico" (SURIAN, 2005, p. 49).

A sanção é positiva e o crismado recebe a sanção cognitiva de reconhecimento como "perfeito cristão" e "soldado de Jesus Cristo". Por meio da sanção cognitiva, com o julgamento da conduta do sujeito, na qual o sujeito é reconhecido e considerado cumpridor do contrato, o actante sujeito é integrado ao sistema de valores proposto e permanece em conjunção com o $\mathrm{O}_{\mathrm{v}}$ e como membro da Igreja.

Dado o poder e autoridade conferidos ao enunciador do catecismo, respaldados pelos valores da ideologia católica e pelo caráter de autoridade da Palavra Revelada, fazem com que este proceda à construção da lição catequética como um texto instrucional.

O catecismo considerado funciona como um PN de uso para que se obtenha o PN de base representado por meio da manutenção da aquisição do $\mathrm{O}_{\mathrm{v}}$ "graça divina". 
Tomando como base que: "toda Seqüência Narrativa do Enunciado (SN1) corresponde, portanto, à atualização da competência do enunciatário (SN3) antes de sua realização" (DISCINI, 2004a, p.114), podemos considerar o enunciado do catecismo como um texto instrucional programador, na medida em que possibilita ao destinatário a aquisição de uma competência: saber ser e poder ser católico.

PN de base: $\mathrm{S}_{1} \rightarrow \mathrm{PN}$ de uso [aceitar a doutrinação de um modo de vida cuja receita é dada no enunciado do catecismo]

Tomemos como base o seguinte trecho extraído do catecismo:

\footnotetext{
*121. Quais os principais deveres de um crismado? Os principais deveres de um crismado são: $1^{\circ}$. Guardar fielmente os mandamentos de Deus e da Igreja. $2^{\circ}$. Defender corajosamente a vida divina em seu coração dos perigos do mundo, do demônio e das más inclinações.

$3^{\circ}$. Amar a Santa Igreja e trabalhar por ela, sem respeito humano, como bom apóstolo (SURIAN, 2005, p. 48).
}

Podemos assim, dado o caráter injuntivo do texto, aproximá-lo do discurso pedagógico.

Desse modo, o enunciado do catecismo se constitui, tal como o discurso pedagógico, como um enunciado prescritivo, regido por um dever-fazer, subentendido ao texto. $\mathrm{O}$ enunciador se preocupa em transmitir as modalidades do saber-fazer, do dever-fazer e do poder-fazer. Ele se apresenta como uma proposição que leva o enunciatário a poder e saber ser católico.

Esse enunciado visa estabelecer um contrato fiduciário com o enunciatário, para que este adquira a competência esperada e possa manter-se, por meio da paixão do medo, em conjunção com os valores propugnados pelo catolicismo. 
Estabelece-se um simulacro (conjunto de modalidades e papéis actanciais) do que deve ser um membro de um grupo social e agir em não conformidade com ele é motivo de vergonha ou de medo (FIORIN, 1992, p. 56).

O medo pode ser classificado em dois tipos de acordo com a concepção de Fiorin (1992, p. 57):

Deve-se insistir que há dois tipos de medo: um derivado da possibilidade de uma sanção pragmática negativa (medo dissuasório) e outro de uma performance vista como ameaçadora. (FIORIN, 1992, p. 57)

A paixão do medo, operacionalizada pelo catecismo com os "perigos do mundo", o "demônio" e as "más inclinações" (cf. SURIAN, 2005, p. 48), pode ser caracterizada, de acordo com Fiorin (1992), sob a tipologia de medo dissuasório, já que agir em não conformidade com esse discurso, proveniente da norma institucional católica, poderia corresponder para o fiel à perda do dom divino e da possibilidade de salvação no plano espiritual.

Assim, com base nessas noções, vejamos como se constitui a $\mathrm{SN}_{3}$ como construção do significado pelo enunciatário por intermédio da enunciação.

O destinador-manipulador (catequista), revestido pelo poder que lhe foi delegado como o responsável pela instrução e doutrinação nos princípios de matéria religiosa, dirige-se ao enunciatário-sujeito (catecúmeno), por meio da construção do simulacro negativo do páthos deste destinatário disjunto dos princípios da fé, da moral e da prática católicas. Esse simulacro negativo se apóia no texto mediante a instituição das perguntas e respostas (perguntas retóricas), que visam ao ensino do sacramento da crisma:

118. Como é que Jesus nos faz seus soldados?

Jesus nos faz seus soldados pela crisma.

*119. Que é a crisma?

A crisma é o sacramento que nos dá o Espírito Santo, imprime na alma o caráter de soldado de Jesus Cristo e faz-nos perfeitos cristãos (SURIAN, 2005, p. 47). 
A eficácia desse discurso se exerce por meio do reconhecimento da autoridade daquele que o profere, repousando esta por meio da crença na recepção do sacramento da crisma como garantia da salvação.

Ele foi crismado. Com a força do Espírito Santo, vence as tentações e não deixa de cumprir seus deveres de católico (SURIAN, 2005, p. 49).

O destinador-manipulador busca estabelecer um contrato fiduciário com o destinatário-sujeito por meio da crença na palavra revelada pela divindade, obtida e conservada por intermédio da religião católica.

A palavra revelada (Atos dos Apóstolos), ao ser citada em "A" é instituída como fonte e fiadora desse discurso, legitimando o enunciado catequético.

\section{JESUS NOS FAZ SEUS SOLDADOS}

(․ㅛ: At 8, 14. B: 282.).

Abaixo, transcrevemos novamente o relato bíblico de Atos dos Apóstolos $(8,14)$ :

Os apóstolos, que estavam em Jerusalém, tendo ouvido que a Samaria acolhera a palavra de Deus, enviaram-lhes Pedro e João. Estes, descendo até lá, oraram por eles, a fim de que recebessem o Espírito Santo. Pois não tinha descido ainda sobre nenhum deles, mas somente haviam sido batizados em nome do Senhor. Então começaram a impor-lhes as mãos e eles recebiam o Espírito Santo (At. 8,14) (BÍBLIA de Jerusalém, 2004, p. 1915).

Assim, por meio de um programa narrativo baseado em um contrato fiduciário, o destinador busca convencer o destinatário-sujeito por meio do argumento de autoridade expresso pela referência à palavra divina, à Luz de Cristo e à tradição viva da Igreja.

A modalização deôntica apresenta um programa de ação por meio de um dever-fazer instaurado pelo destinador: dever agir como um leigo, um crente católico. Ao operar com a 
revelação dos saberes a respeito do conteúdo da fé católica, o discurso busca a adesão do destinatário por meio da manipulação executada pela modalização deôntica do dever-fazer (prescrição). É pela modalização deôntica que são propostas ao mesmo tempo, tentações e intimidações. De tal forma que o enunciador manipula o enunciatário para dever-saber e crerpoder-saber entrar em conjunção com os valores ideológicos propostos. Dessa forma, o modo próprio do enunciador desse discurso busca a adesão de sua imagem pelo enunciatário a ele pressuposto, que deve, por conseguinte, partilhar das crenças e valores propostos por esse enunciado.

Esse discurso, por meio de seu texto instrucional e doutrinário pautado pelo tom professoral, estabelece um lugar de mediação entre o Espírito Santo e o catecúmeno (aquele que se prepara e se instrui para apreender a doutrina religiosa católica). O tom professoral, obtido por meio da simbiose actorial operacionalizada entre a figura divina e o agente religioso, constrói uma manipulação para que o leitor-aprendiz (actante coletivo), tendo sido persuadido e realizado a adesão ao objeto do saber, e, portanto, deonticamente modalizado, queira aprender os fundamentos pertencentes à ideologia religiosa católica.

Assim, o enunciador busca levar o enunciatário por meio da modalidade deôntica do dever, para que este adquira a competência esperada pelo seu comprometimento com os ideais propostos pela doutrina católica, levando-o, portanto, à conjunção com o objeto de valor que estaria representado pelos princípios da fé, prática e moral católicas.

O sujeito cristão, ao se incorporar à Igreja, institui-se como um leigo, que além de aprender a doutrina católica, deve exercer a ação apostólica, o "múnus sacerdotal”, tido como tarefa sagrada, na qual o fiel deve contribuir para a propagação da Boa Nova católica em todos os campos sociais.

O catecúmeno, para entrar em conjunção com o objeto de valor almejado, deve concordar com o contrato estabelecido. Ao adquirir a competência de um dever-fazer e de um 
poder-fazer, proposto pelo sujeito por meio da modalidade factitiva, e também ao crer como verdadeiro esse discurso, o catecúmeno deve realizar a performance da confirmação com a crisma e glorificação da Santa Igreja, cumprindo os "principais deveres de um crismado" (SURIAN, 2005, p. 47), tal como se presentifica no próprio enunciado do catecismo. A performance a ser realizada pelo sujeito caracteriza-se sob a perspectiva pragmática pelos gestos e atos presentes nas seguintes seções: Na liturgia, Oração, Missão a Cumprir e Devo guardar para a vida; ou pela realização de ações cognitivas, tal como se pode observar nos seguintes deveres:

*121. Quais são os principais deveres de um crismado?

Os principais deveres de um crismado são:

$1^{\circ}$. Guardar fielmente os mandamentos de Deus e da Igreja

$2^{\circ}$. Defender corajosamente a vida divina em seu coração dos perigos do mundo, do demônio e das más inclinações.

$3^{\circ}$. Amar a Santa Igreja e trabalhar por ela, sem respeito humano, como bom apóstolo. (SURIAN, 2005, p. 49)

Dessa maneira, a lição apresenta-se como um elemento persuasivo, ou seja, como um instrumento de doutrinação para catequizar o enunciatário, para que este viva em conformidade com os padrões da doutrina e cultura católicas, percurso este ameaçado pelo demônio (PN implícito), representado como anti-destinador dos ideários apregoados pelo catolicismo.

\section{PN do anti-sujeito (demônio, más inclinações)}

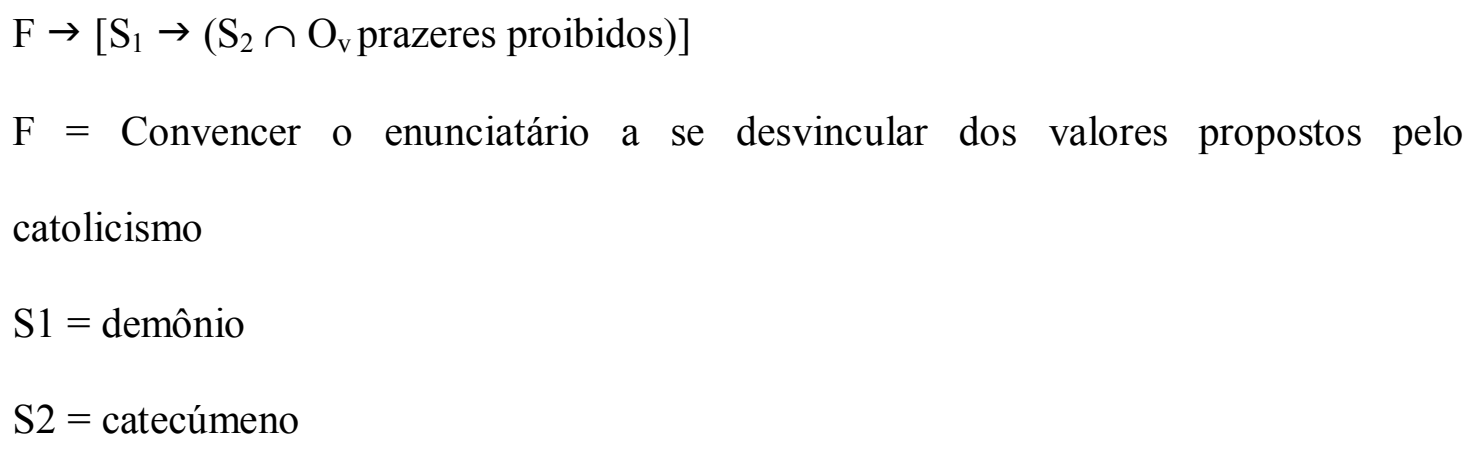


$\mathrm{Ov}=$ prazeres proibidos (tentações mundanas)

O PN narrativo principal, estabelecido pelo catecismo, põe-se contra o PN contrário aos valores apregoados.

Assim, tendo o fiel católico como leitor pressuposto, o "outro", ao qual este discurso se destina, o destinador do texto católico estabelece uma catequese sobre os princípios dogmáticos do catolicismo para fazer com que o leitor, por meio de uma manipulação baseada na intimidação (se o fiel não crer nos dogmas católicos não obterá a salvação), acredite em seu relato, cristalize sua fé em Deus, representada por meio da figura de Jesus e do Espírito Santo e, conseqüentemente, seja sancionado positivamente com a recepção da crisma ou confirmação, um dos sinais produtores da graça, como um dom sobrenatural instituído por Deus para que se possa alcançar a salvação.

Tomaremos como princípio os mecanismos de sintaxe discursiva (debreagem e embreagem) com a instauração no enunciado das categorias de pessoa, tempo e espaço.

Vejamos o seguinte trecho:

* 120. Porque a crisma se chama também confirmação?

A crisma se chama também confirmação, porque confirma em nós a vida recebida no batismo e nos dá maior resistência aos assaltos da tentação (SURIAN, 2005, p. 48).

O texto do catecismo, objeto de nossa análise, apresenta-se caracterizado por meio da utilização da enunciação enunciada, verificada pela presença de marcas textuais que remetem à instância da enunciação.

No que diz respeito à categoria de pessoa, instaurada no enunciado da unidade considerada para análise, observamos a presença do terceiro nível da hierarquia enunciativa. Quem fala são os actantes do enunciado: interlocutor e interlocutário. 
O narrador (implícito ao enunciado), por meio de uma debreagem enunciativa de segundo grau, delega voz aos actantes do enunciado (interlocutor e interlocutário), instaurando o diálogo.

Observamos o estabelecimento do simulacro de uma interação conversacional de uma aula de catequese por meio da instauração de perguntas e respostas. As questões possuem a forma imperativa por meio do emprego de perguntas retóricas. Simula-se um jogo de vozes (a do interlocutor e a do interlocutário) que viabiliza o simulacro de um efeito de polifonia.

Por meio da instauração dessa cena, obtém-se o efeito de sentido de anulação da distância entre enunciação e enunciado. Esse jogo de vozes constrói uma ilusão de realidade, a ilusão de uma situação real de diálogo entre catequista e catequizando. Simula-se a cena de doação de saber, do ensino da doutrina, pautada pela exposição do conteúdo realizada pelo catequista e pela expectativa de assimilação do catequizando.

A relação entre catequista e catecúmeno dá-se mediante a noção de projeção e operacionalização de simulacros do contrato simulado entre ambos.

Ao observar as seções, das quais se compõe a referida lição, podemos atentar para procedimentos de actorialização característicos. Vejamos, portanto, como são instaladas as marcas de pessoa no enunciado considerado.

Observemos inicialmente os dizeres da moldura que resumem a lição:

O Espírito Santo Habita em mim.

Lutarei por Deus e pela Igreja (SURIAN, 2005, p. 47). (grifo nosso)

Há a instauração, no enunciado, de um "tu" interlocutário delegado do narrador implícito ao enunciado. Esse "tu" enuncia-se por meio do pronome oblíquo tônico "mim" e por meio da desinência verbal de primeira pessoa em "lutarei".

No que concerne à lição catequética, interlocutor e interlocutário enunciam-se por meio do uso do pronome pessoal reto "nós" e pelo uso do pronome pessoal oblíquo átono 
"nos". Esse "nós" configura-se como um "nós" inclusivo (eu + você + eles $=$ nós, esta comunidade religiosa), o que confere alto grau de subjetividade ao enunciado, ao operar com a transmissão de um saber dado mediante identificação e anulação da distância entre enunciador e enunciatário.

O conceito de subjetividade na linguagem se refere à proposição de Benveniste (1995, p. 286):

A "subjetividade" de que tratamos aqui é a capacidade do locutor para se propor como "sujeito". [...] Ora, essa "subjetividade", quer a apresentemos em fenomenologia ou em psicologia, como quisermos, não é mais do que a emergência no ser de uma propriedade fundamental da linguagem. É "ego" que diz "ego". Encontramos aí o fundamento da "subjetividade" que se determina pelo status lingüístico da "pessoa".

A consciência de si mesmo só é possível se experimentada por contraste. Eu não emprego eu a não ser dirigindo-me a alguém, que será na minha alocução um tu. Essa condição de diálogo é que é constitutiva da pessoa, pois implica uma reciprocidade - que eu me torne $t u$ na alocução daquele que por sua vez designa por eu (BENVENISTE, 1995, p. 286).

Viabiliza-se o simulacro de um jogo de vozes, o "eu" que pergunta e o "tu" que responde, com a utilização da mesma pessoa gramatical: um nós generalizado, de toda pessoa, lugar e espaço.

Ex: *118. Como é que Jesus nos faz seus soldados?

Jesus nos faz Seus soldados pela crisma. (SURIAN, 2005, p.47)

* 120. Porque a crisma se chama também confirmação?

A crisma se chama também confirmação, porque confirma em nós a vida recebida no batismo e nos dá maior resistência aos assaltos da tentação. (SURIAN, 2005, p.48) (grifo nosso)

No que diz respeito à seção denominada "Na Liturgia", também se presentifica a voz do interlocutário dada por meio do pronome "nós".

Marcando-nos com a unção da cruz na testa, a crisma nos torna propriedade sagrada do Senhor (SURIAN, 2005, p. 48). (grifo nosso) 
Por sua vez, na seção "Oração”, observa-se a presença da primeira pessoa por meio do vocativo que afirma o chamamento do sujeito dado por meio do sintagma cristalizado: "Ó Espírito Santo". O "eu”, representado por meio do interlocutor, se dirige, em oração, ao Espírito Santo. Isso reforça o caráter invocativo do sujeito em falta, elidido e disposto numa posição de inferioridade.

\section{ORAC̣̃̃O \\ Ó Espírito Santo, vinde habitar em meu coração e tornai- me um templo vivo, onde brilhe a Vossa glória. Amém.}

Ilustração 8 SURIAN, Frei Carmelo. Primeiro catecismo da Doutrina Cristã. 145 ed. São Paulo: Vozes, 2005, p. 48.

Dá-se a presença da não-pessoa "ele" unicamente no final do texto como legenda da ilustração didática, apenas para dar o caráter de exemplo a ser seguido por qualquer indivíduo, construído sob a hipótese de que esse "ele" pode ser válido para qualquer um que se disponha a aceitar os preceitos católicos. Esse caráter é reforçado na ilustração didática que acompanha a legenda, mediante a diagonalidade das linhas saindo de um centro único, caracterizando a iminência do encontro do homem com Deus.

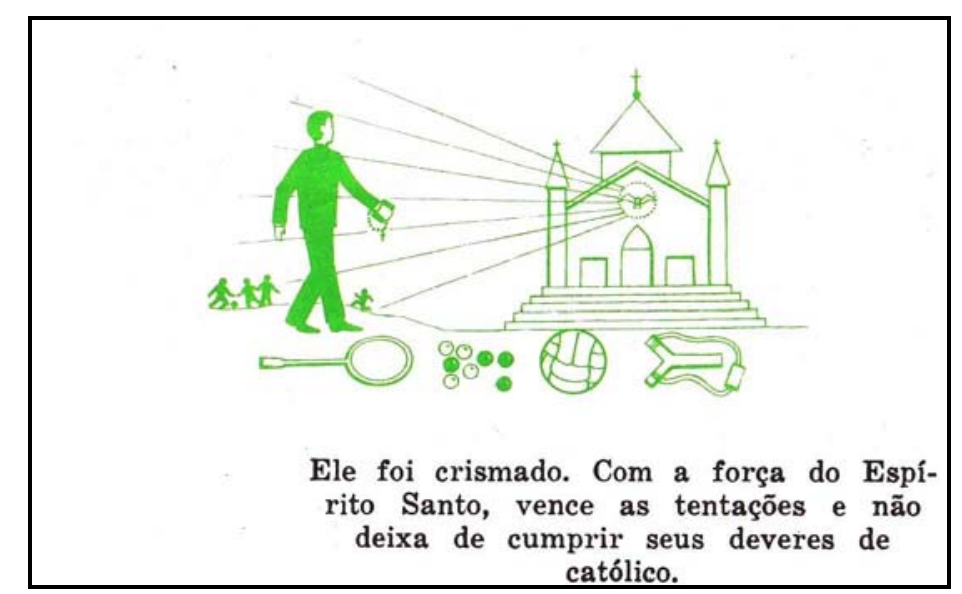

Ilustração 9 SURIAN, Frei Carmelo. Primeiro catecismo da Doutrina Cristã. 145 ed. São Paulo: Vozes, 2005, p. 49 . 
O enunciado do catecismo operacionaliza uma debreagem temporal enunciativa, uma vez que "se projetam no enunciado os tempos do sistema enunciativo" (FIORIN, 2002, p. 147). Nesse nível, a debreagem também será dita de segundo grau, por se encontrar relacionada à categoria do interlocutor, delegada do narrador implícito e instaurada na forma de diálogo.

Estando construído dentro do sistema enunciativo, o enunciado do catecismo pauta-se, assim como a lógica cartesiana, em relação ao "agora", em concomitância ao marco referencial presente. Relaciona-se, portanto, a um momento de referência presente, idêntico ao momento da enunciação.

O tempo verbal característico desse discurso é o presente omnitemporal ou gnômico. Fato que o constitui como um enunciado válido para qualquer lugar ou época histórica e o caracteriza como um enunciado próprio da esfera de circulação do discurso religioso, utilizado para a enunciação de verdades eternas.

O texto catequético ao ser organizado ao redor da instância do "aqui” simula uma cena enunciativa por meio da instauração do diálogo. O espaço lingüístico é expresso no enunciado do catecismo mediante a utilização dos advérbios de lugar. Observamos a presença dos advérbios enunciativos (aqui, aí e lá). “Aqui e aí marcam o espaço da cena enunciativa, sendo que este assinala o espaço do $e u$, e aquele, o do $t u$; ali indica o espaço fora da cena enunciativa" (FIORIN, 2002, p. 269).

A cena dialógica caracteriza-se pela irreversibilidade de posições enunciativas: Jesus Cristo/ Espírito Santo (lá), catecúmeno (aí) e o catequista como intermediário entre os planos espaciais (aí) e o espiritual (lá). O enunciado constrói, por meio da irreversibilidade, uma proxêmica dada na ordem da estabilidade. A estaticidade, que permeia a formação ideológica considerada, produz o simulacro de um mundo estabilizado com lugares definidos. 
A figura de Jesus Cristo/Espírito Santo, ao se instituir na ordem do inefável, transcende os limites humanos e consolida a isotopia da santidade. O catecúmeno se institui mais próximo do espaço, cabendo ao agente religioso (catequista) proceder à intermediação entre esses dois planos.

Temos, portanto, a espacialização dada na ordem da verticalidade, pautada pela direção superativa no eixo da verticalidade. O olhar da verticalidade constrói o plano espiritual a partir do ponto de vista eufórico, estabelecendo o "alto" como categoria. Seu olhar, mediado pela instância intermediadora do agente religioso, constrói-se por meio do "baixo" (disfórico) para o "alto" (eufórico).

Ó Espírito Santo, vinde habitar em meu coração e tornai-me um templo vivo, onde brilhe a Vossa glória. Amém (SURIAN, 2005, p. 48).

Temos, por meio desse exemplo, a visão do baixo disfórico, do sujeito em falta, um sujeito que não é, mas pode vir a ser por meio da sua invocação oracional pautada na fé. Remetemo-nos ao texto do catecismo (cf. Seção: Anexos) para que possamos proceder aos procedimentos de tematização e figurativização característicos.

O catecismo, como resumo da fé professada pelos católicos, representa em sua configuração temática a busca pelo conteúdo da fé, da moral, da prática cristã e da defesa da vida divina e da Santa Igreja por meio do seguinte investimento temático: a) tema da beligerância necessária à constituição do sujeito; b) tema da perfeição do homem; c) tema da incondicionalidade do dogma; d) tema da dependência entre salvação/dogma; e) tema da irrestrição da entrega a Deus e, portanto, do abandono das coisas do mundo; f) tema da fidelidade obrigatória à Igreja; g) tema da manutenção dos valores da tradição; h) tema do pecado original (confissão).

Vejamos, então, como esses temas recebem seu revestimento figurativo condizente com o sistema de restrições católicas ao longo do catecismo, por meio de elementos sensoriais 
próprios do discurso religioso, e como seu encadeamento figurativo ao longo do texto representa a concretização dos temas anteriormente mencionados. Bertrand (2003, p. 420) estabelece a noção de figurativização da seguinte forma:

Todo conteúdo de um sistema de representação (visual, verbal ou outro) que tem um correspondente no plano da expressão do mundo natural, isto é, da percepção. As formas de adequação, configuradas pelo uso, entre a semiótica do mundo natural e a das manifestações discursivas, formam o objeto da semiótica figurativa. Esta se interessa, pois, pela representação (a mimeses), pelas relações entre figuratividade e abstração, pelos vínculos entre a atividade sensorial da percepção e as formas de sua discursivização (BERTRAND, 2003, p. 420).

A temática da proteção e defesa da vida divina, instituída pelo Espírito Santo, e da defesa da Santa Igreja, recebem o seguinte investimento figurativo pautado pela isotopia da proteção dessas propriedades: Jesus Cristo, Espírito Santo, soldado de Jesus Cristo, templo vivo do Espírito Santo, propriedade sagrada do Senhor.

O tema dos princípios católicos é figurativizado por meio dos seguintes elementos constituintes da isotopia ritualística do cerimonial religioso, representativos de simbologia instituída como sinais sacramentais da ritualística da confirmação: crisma, liturgia, Santa Missa, Sua Santa Igreja, unção, cruz, hóstia, vinho. Esses elementos estão presentes na seção "na liturgia", que transcrevemos a seguir:

\section{Na Liturgia}

Marcando-nos com a unção da cruz na testa, a crisma nos torna propriedade sagrada do Senhor. Por isso, em todas as santas missas de que participamos, juntamente com o ofertório da hóstia e do vinho, devemos renovar a oferta de nós mesmos ao serviço do Senhor e da Sua Santa Igreja (SURIAN, 2005, p. 48). (grifo nosso)

Vejamos como se constituem cada uma dessas figuras dentro do sistema de restrições semânticas do discurso católico: 
Crisma: "Sacramento que confirma o batismo" (HOUAISS, 2004, p. 201).

Liturgia: "Conjunto de elementos e práticas do culto religioso católico (missa, orações, sacramento, etc.)" (HOUAISS, 2004, p. 460).

A liturgia é a celebração do Mistério de Cristo e em particular do seu Mistério pascal. Nela, mediante o exercício do ofício sacerdotal de Jesus Cristo, é por sinais significada e realizada a santificação dos homens e se realiza pelo Corpo místico de Cristo, ou seja, pela cabeça e pelos membros, o culto público devido a Deus (BENTO XVI, 2005, p. 79).

Santa Missa: Representa a celebração do sacramento da eucaristia, no qual o pão e o vinho se convertem em corpo e sangue de cristo (cf. HOUAISS, 2004, p. 730).

Sua Santa Igreja: Representa a santidade da Igreja aos olhos da fé (cf. JOÃO PAULO II, 2001, p. 237).

\section{Unção:}

A unção com o santo crisma depois do Batismo, na Confirmação e na Ordenação, é o sinal de uma consagração. Pela Confirmação, os cristãos, isto é, os que são ungidos, participam mais intensamente da missão de Jesus e da plenitude do Espírito santo, de que Jesus é cumulado, a fim de que toda a vida deles exale "o bom odor de cristo". Por esta unção, o confirmado recebe a "marca", o selo do Espírito Santo (JOÃO PAULO II, 2001, p. 358).

\section{Cruz:}

O sinal da cruz no limiar da celebração, assinala a marca de Cristo naquele que vai pertencer-lhe e significa a graça da redenção que cristo nos proporcionou por sua cruz. (JOÃO PAULO II, 2001, p. 345) 
Hóstia: "No catolicismo pequena rodela muito fina de pão sem fermento, consagrada pelo padre e oferecida aos fiéis na comunhão" (HOUAISS, 2004, p. 393). Representa o corpo de Cristo dento do mistério eucarístico.

Vinho: Presente no mistério eucarístico como o sangue de Cristo.

Jesus Cristo está presente na Eucaristia de modo único e incomparável. Está presente, com efeito, de modo verdadeiro, real, substancial: com o seu Corpo e o seu Sangue, com a sua Alma e a sua Divindade. Nela está, portanto, presente de modo sacramental, ou seja, sob as duas espécies eucarísticas do pão e do vinho, Cristo todo inteiro: Deus e homem (BENTO XVI, 2005, p. 95).

O “outro" que representa o seu contrário é negado. O que não fizer parte da competência discursiva do enunciador católico e ao sistema de restrições semânticas partilhado é deslocado para o plano negativo da "alteridade".

As figuras ressemantizadas pelo discurso católico apresentam em si a negação de seu contrário, no caso, o percurso da ludicidade dos valores profanos. Esse percurso encontra-se presente neste discurso no que diz respeito à temática da tentação, sustentáculo dos princípios do catolicismo. Com relação a esse percurso, observamos o seguinte revestimento figurativo: perigos do mundo, demônio e más inclinações.

*121. Quais os principais deveres de um crismado?

Os principais deveres de um crismado são:

$1^{\circ}$. Guardar fielmente os mandamentos de Deus e da Igreja.

$2^{\circ}$. Defender corajosamente a vida divina em seu coração dos perigos do mundo, do demônio e das más inclinacões.

$3^{\circ}$. Amar a Santa Igreja e trabalhar por ela, sem respeito humano, como bom apóstolo (SURIAN, 2005, p. 48). (grifo nosso) 
Desse modo, o enunciado do catecismo, embora revestido figurativamente, pode ser definido como um texto temático, mediante o caráter dogmático e doutrinário que o constitui e também pela rarefação sêmica das próprias figuras.

O enunciado catequético considerado trabalha predominantemente com abstrações, tomando até termos concretos em seu valor genérico. É o caso do sacramento da crisma ensinado aos cristãos. O catecismo, ao se constituir como um texto temático, não se destina a contar episódios bíblicos, a reduplicar atores do enunciado do texto de fundação, mas prioriza explicações dos mistérios da fé mantendo, entretanto, a intocabilidade dos mesmos mistérios. O que é concretamente a crisma? O leitor do catecismo católico não saberá nem deverá querer saber. Interessante é que a crisma, detalhada como elemento que fornece maior resistência aos assaltos da tentação não oferece um detalhamento figurativo da sua composição. Mantêm-se o inexplicável, para manter-se a fé. 


\subsection{Manifestação: A cenografia considerada como uma unidade sincrética}

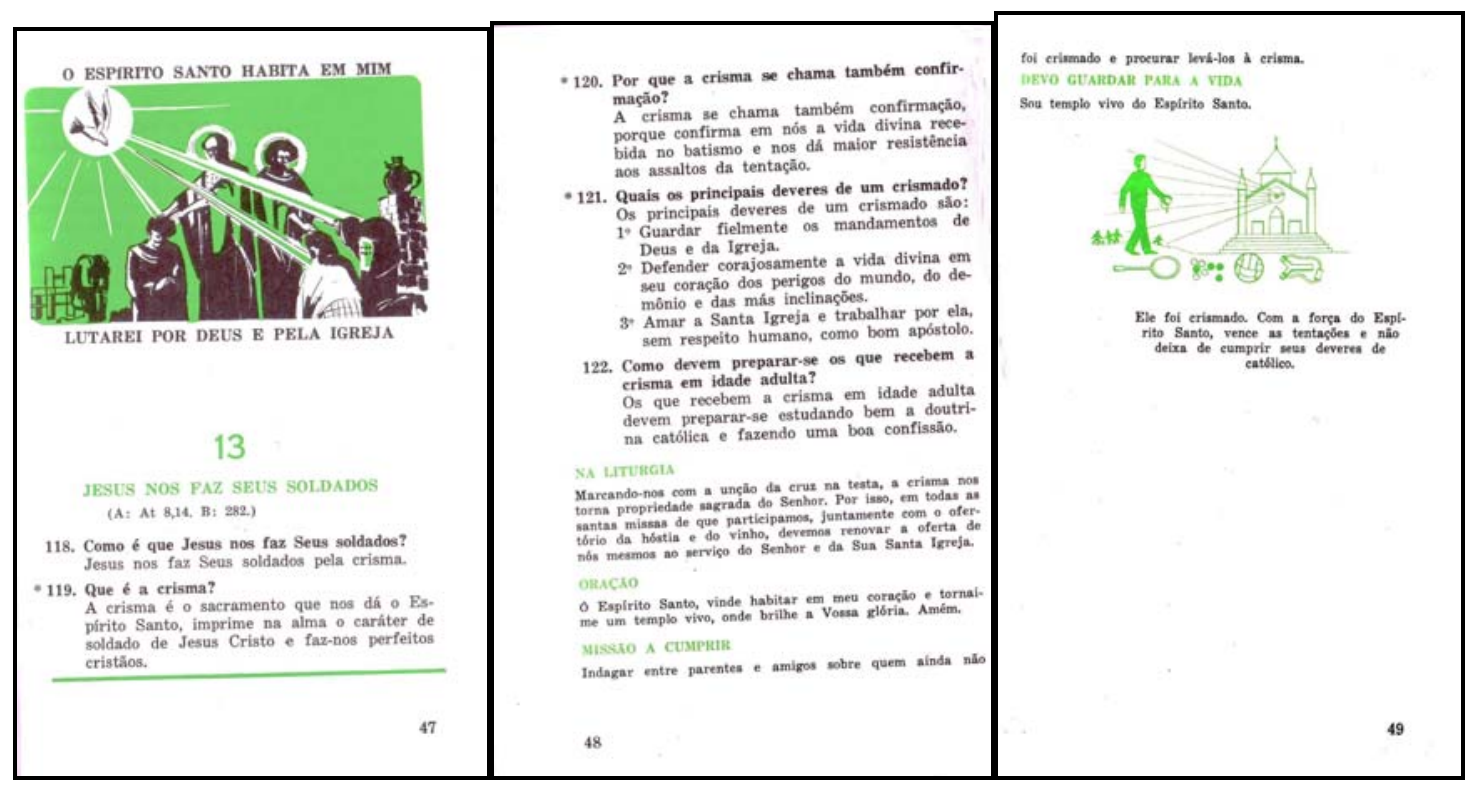

Ilustração 10 SURIAN, Frei Carmelo. Primeiro catecismo da Doutrina Cristã. 145 ed. São Paulo: Vozes, 2005. p. 47. -49 .

Floch (1985) faz a distinção entre um modo sintagmático e um modo paradigmático de fazer sincretismo. O enunciado considerado, ao apresentar um sincretismo sintagmático, supõe que a depreensão do sentido seja dada por meio das relações estabelecidas entre os dois sistemas (verbal e visual), de que se compõe o catecismo.

O enunciado do catecismo configura-se como um texto sincrético, desse modo, configura-se uma práxis enunciativa no enunciado catequético considerado ao fixar um modo específico de composição das diferentes linguagens de manifestação. Assim, ao tomarmos o enunciado do catecismo como um texto sincrético, devemos considerar a co-ocorrência dos elementos visuais e verbais, dados por meio da utilização das ilustrações didáticas e da lição catequética como uma totalidade, uma única unidade de sentido. A articulação entre as diferentes linguagens, constituindo com elas uma unidade de sentido, assegura um modo de presença, um estilo, um éthos. 
Para que possamos depreender o éthos, o estilo como modo de dizer próprio a esse discurso, devemos levar em conta a homologação das categorias do PC e do PE uma vez que: o conteúdo presente na ilustração se submete às coerções do material plástico e essa materialidade também significa.

$\mathrm{Na}$ tentativa de delinear o modo de presença, o éthos do ator da enunciação como tom, voz, caráter e corporalidade da unidade (unus) considerada para análise, devemos levar em conta a totalidade (totus), da qual fazem parte as seguintes seções, produzidas pela constituição diagramática do enunciado catequético considerado: a) lição baseada numa história bíblica, ilustrada nas cores verde, branco e preto no cabeçalho; b) presença de dizeres que resumem a lição dispostos na moldura das ilustrações; c) número da lição correspondente; d) título da lição; e) a presença dos seguintes índices (A-B) no início de cada lição; f) doutrina em perguntas e respostas. Também se verifica a presença de seções referentes à vida litúrgica, interior e apostólica dos catecúmenos: Na liturgia, Oração, Missão a cumprir, Devo Guardar para a vida ; Presença de Ilustrações Didáticas.

Assim, buscamos fazer a seguir uma breve incursão nos procedimentos da categoria plástica por meio da análise das ilustrações que compõe a lição em pauta para análise, de modo que, o sentido do texto do enunciado catequético considerado possa ser dado por meio da co-ocorrência entre os dois sistemas, verbal e visual, em uma única unidade de sentido.

A ilustração didática, um sistema semiótico plástico, ao operar a homologia com o sistema semiótico verbal do catecismo, pode defini-lo como um enunciado sincrético. Barthes (1984), ao estabelecer as relações que a mensagem lingüística pode realizar em relação ao sistema semiótico plástico, propõe a existência de duas funções distintas que a palavra pode exercer em relação à imagem: ancoragem e etapa. 
A função de ancoragem corresponde à função de elucidação do enunciado visual por meio da recorrência ao verbal, tal como se observa, por exemplo, na utilização de legendas. Já com relação à função de etapa, palavra e imagem exercem uma função complementar, de tal modo que, a unidade da mensagem se dá na totalidade do enunciado considerado.

Por meio da lição catequética considerada, observamos a presença de um sincretismo entre imagem e palavra com função de etapa. A estratégia enunciativa que sincretiza as diferentes linguagens de manifestação, numa totalidade de sentido, exerce-se de modo contratual.

No que concerne à coerção das imagens, observamos que as ilustrações didáticas, tal como nas Bíblias ilustradas, ao apresentarem uma função pedagógica, têm como objetivo tornar esse discurso mais palatável, pois a coerção se dá pelo verbal, ao operacionalizar a colocação de categorias da crença a todo o momento.

No que diz respeito à imagem presente no cabeçalho do texto, observamos a figurativização do rito cerimonial católico (instituído pelos apóstolos, tal como consta no discurso fundador de Atos 8,14), por meio da instituição do sacramento da crisma.

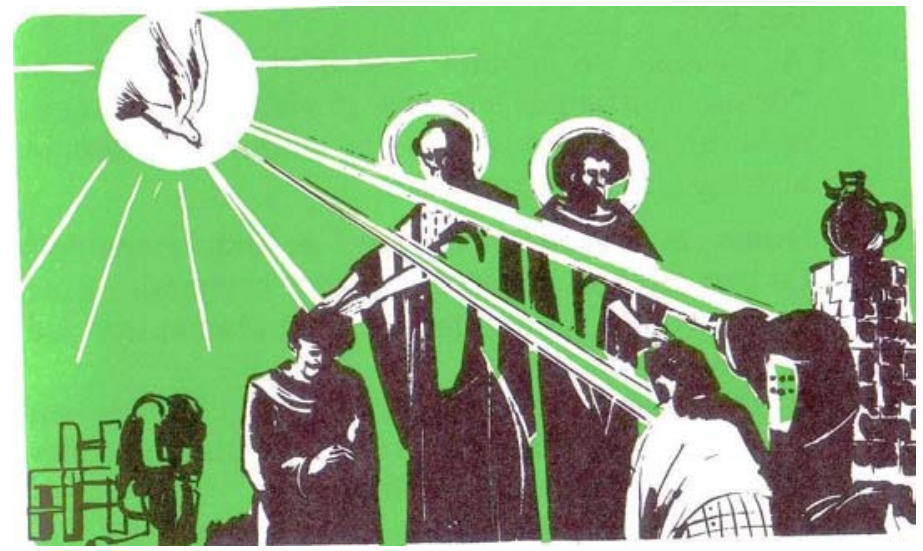

Ilustração 11 SURIAN, Frei Carmelo. Primeiro Catecismo da Doutrina cristã. 145 ed. Petrópolis:Vozes, 2005, p.47.

O papel dessa ilustração didática, ao remeter ao texto bíblico de Atos dos Apóstolos $(8,14)$, confere a intertextualidade ao plano do conteúdo da lição catequética. 
A utilização de uma ilustração representativa da História Bíblica na qual a lição se baseia $($ At 8,14$)$ apresenta função essencialmente pedagógica no enunciado do catecismo. Esse gênero de pintura se traduz "por um interesse exclusivo pela pintura religiosa, permitindo visualizar exatamente o que dizem os textos sagrados" (MAINGUENEAU, 2005a, p. 154).

Pintura que será, pois, uma pintura essencialmente pedagógica, devendo o quadro gerar a mensagem de Deus em cada um de seus detalhes. Em poucas palavras, é necessária "uma história verdadeira e apropriada para honrar a Deus instruindo fielmente os homens" (MAINGUENEAU, 2005a, p.154).

A ilustração representativa da História bíblica em que a lição se baseia apresenta como temática a celebração da liturgia sacramental da Igreja Católica, de modo especial, a celebração do sacramento da crisma. A crisma, sacramento que confirma o batismo, é vista como um dos sete sacramentos instituídos por Jesus Cristo como sinal de purificação da alma, auxiliar e indispensável para que se possa alcançar a vida eterna. Sinal de reconhecimento e comunhão entre aqueles partidários da mesma formação ideológica do catolicismo.

No que concerne ao (PN), "sintagma elementar da sintaxe narrativa", (BARROS, 2002, p. 31), observamos a transformação principal operacionalizada por esse discurso como a ação de um sujeito sobre outro, para que este último possa manter-se em conjunção com o objeto valor "graça divina".

Assim, o programa de base que rege esse discurso pode ser descrito como segue:

PN de base: $\mathrm{S}_{1} \rightarrow \mathrm{S}_{2} \cap \mathrm{O}_{\mathrm{v}}$

$\mathrm{S}_{1}=$ Ministro Sacramental; $\mathrm{S}_{2}=$ cristão; $\mathrm{O}_{\mathrm{v}}=$ graça divina . 
Desse modo, por meio de um PN de uso, alcançado pela administração do sacramento da crisma, tem-se instaurado no enunciado um programa de doação de competência pela recepção do dom do Espírito Santo. Os apóstolos, tidos como os legítimos responsáveis pela administração desse sacramento, comunicam por meio dos ritos, sinais, palavras e ações os dons do Espírito Santo, que levam o sacramento da crisma à sua consumação.

Para procedermos à análise do plano de expressão dessa imagem, partimos das reflexões elaboradas por Floch $(1985,1987)$, concernentes à análise do plano de expressão das semióticas visuais (planas ou bi-dimensionais), por meio do reconhecimento de formantes figurativos e formantes plásticos.

O estabelecimento de uma primeira segmentação do quadro, ao ser determinado a partir da oposição de relações entre elementos visuais, permite-nos reconhecer a divisão do espaço representado por meio da articulação de três unidades discretas: uma parte esquerda, uma parte direita e uma parte central. Os dois apóstolos apresentam-se no centro do quadro, braços estendidos para a realização do rito cerimonial católico da imposição das mãos. Os apóstolos envoltos pelo dom, graça conferida pelo Espírito Santo, figurativizada pela auréola que lhes circunda a cabeça, comunicam pelo rito da imposição das mãos o dom do Espírito Santo, o qual leva a graça do batismo à sua consumação. À direita do quadro, temos o óleo da crisma para a realização da unção. A estaticidade dos gestos que chamam a atenção para si mesmos remonta à isotopia do equilíbrio, própria à liturgia da Igreja Católica. Observamos a estaticidade temporal determinada pela sacralidade e solenidade do gesto litúrgico. A cobertura dessa narrativa pelas figuras representadas por meio dos símbolos ritualísticos do catolicismo: pomba (Espírito Santo), imposição das mãos e cruz na testa, figurativizam o tema da incondicionalidade do dogma, concretizando o sacramento da confirmação. 
Vejamos como as categorias do plano de expressão podem ser delimitadas por meio da análise de seus componentes: eidético, cromático e topológico, de tal modo que possamos delimitar como os contrastes formados no plano de expressão determinam sua figurativização.

Quanto à forma que pode ser descrita por meio da categoria eidética homogêneo vs. heterogêneo, podemos opor o fundo à ação sacramental da crisma instituída pelos apóstolos. Desse modo, o primeiro tem a sua homogeneidade dada pela regularidade de seu preenchimento como um todo indissociável. Já a ação sacramental é associada à forma heterogeneidade ao levar-se em consideração as poses e contornos distintos dos participantes dessa celebração.

Quanto à disposição das figuras, verificamos a presença de planos pela superposição lado a lado das figuras. A apreensão da totalidade da imagem se dá mediante a categoria multiplicidade, por oposição à unidade do plano de fundo. Quanto ao cromatismo, são colocadas opostamente categorias plásticas monocromático vs. colorido, no que concerne, respectivamente, à oposição dada entre o plano de fundo por meio do cromatismo verde e os celebrantes da ação sacramental que se realizam por meio da trilogia verde-branco e preto.

Quanto à categoria topológica, temos a sua articulação entre horizontal (plano de fundo) e vertical (ações sacramentais).

Para que possamos explicitar o estilo que permeia a imagem considerada, tomaremos como base as reflexões do teórico da arte Heinrich Wölfflin (2000), incorporadas ao quadro teórico da semiótica. As reflexões de Wölfflin (2000) serão utilizadas como procedimentos de tratamento plástico na sua distinção entre o estilo pictórico e o estilo linear nas artes plásticas.

No que diz respeito ao traço, observamos que o quadro considerado desenvolve-se por meio da utilização do estilo linear. O sentido e percepção dos objetos são dados por meio de linhas, formas e contornos bem definidos. Verificamos, nessa imagem, a presença de linhas 
percebidas como limites de superfície. Os olhos são conduzidos dentro dos limites da forma e as imagens são induzidas à percepção táctil.

Verificamos a presença de linhas claras e contornos delimitadores por meio dos quais são discernidas nitidamente uma forma da outra, de tal modo que se tem uma nítida separação entre fundo e figuras. O plano de expressão, de que se constitui a imagem, ao ser limitado pelos contornos bem definidos da moldura, limita o olhar do observador, pautado pela apreensão do limite.

As figuras encontram-se dispostas lado a lado por meio de camadas estruturadas na superfície de um único plano. Sua disposição se dá numa linha horizontal até atingir a moldura da imagem. Esse tipo de disposição justaposta sugere a serenidade e equilíbrio, próprios à celebração litúrgica do catolicismo.

A imagem encontra-se fechada em si mesma, de tal modo que a impressão da imagem seja delimitada pela moldura. Observamos, portanto, a presença de uma proporcionalidade fechada, pautada pela simetria e imobilismo de suas figuras em uma imagem chapada, sem profundidade e sem sugestão de movimento. Notamos uma pluralidade de imagens autônomas, ajustadas de modo harmonioso pela disposição e composição cromática, sugerindo a coordenação e equilíbrio próprios ao estilo linear. A imagem é pautada por uma clareza absoluta, na qual a luz se coloca a serviço da forma, como elemento organizador da realidade e delimitador da nitidez dos objetos.

O PE (plano de expressão do texto), constituído por meio de uma pluralidade de substâncias (plástica e lingüística), estabelece relações com o PC (plano do conteúdo do texto), contribuindo, assim, para a construção do seu sentido, por meio de relações denominadas semi-simbólicas. A semiótica plástica e a teoria dos sistemas semi-simbólicos fazem parte dessa ferramenta teórica ao possibilitar a depreensão das relações entre o plano do conteúdo e o plano da expressão dos textos. Assim sendo, tomando por princípio a 
isomorfia entre os dois planos da linguagem, proposta por Hjelmslev (1975), as conclusões que orientam essa análise serão determinadas mediante a elaboração de relações semisimbólicas por meio da homologação entre categorias semânticas do PC e plásticas do PE.

Consideramos, inicialmente, as categorias topológicas, tidas como categorias próprias do plano de expressão e responsáveis pela posição, orientação das formas e movimentos no espaço. No que diz respeito à disposição da imagem em um plano bidimensional, em que relações lineares se opõem a relações planares, observamos, na imagem considerada, a presença da categoria planar: circundado vs. circundante, aplicada de modo parcial. No entanto, como o circundado não é totalmente fechado pelo circundante ele se desenvolve mediante a categoria cercado vs. cercante.

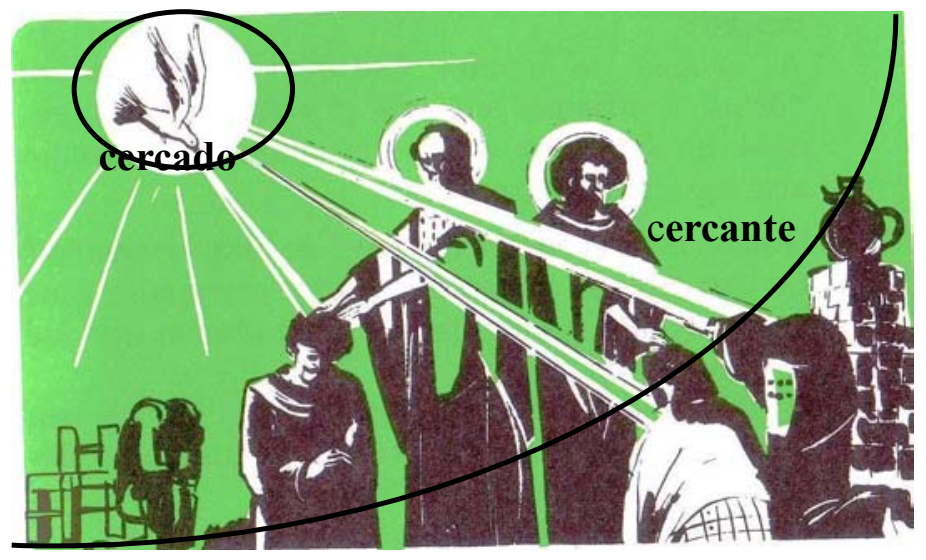

Assim sendo, temos a seguinte relação semi-simbólica:

PC vida/ sagrado vs. profano/morte

PE cercado vs. cercante.

O Espírito Santo aparece no alto da imagem envolto pela glória, representado como uma pomba envolta pelo brilho (dom que a circunda). A difusão desse dom, como graça 
instituída por esse sacramento, é representada por meio das linhas que cortam diagonalmente o quadro do alto às posições periféricas e centrais.

Essa relação permite-nos estabelecer o seguinte semi-simbolismo:

$\mathrm{PE}$ retilineidade/ $\mathrm{PC}$ concentração

PE diagonalidade / PC dispersão do espírito Santo

Os fiéis (recém-batizados) que recebem a confirmação estão dispostos no eixo inferior da imagem, em posição de aceitação, aptos à recepção dos valores católicos propostos. Os fiéis passivos, do ponto de vista do plano do conteúdo, são modalizados por meio do querer, dever, poder e saber-ser conjuntos com os valores propostos. No canto esquerdo um homem solitário figurativiza-se pela passividade e desfalecimento no plano do conteúdo. Portanto, um sujeito pautado pela falta patêmica, modalizado pelo saber-não-poder e crer-não-poder-saber estar conjunto com os valores ideológicos católicos. Um sujeito resignado, portanto. A ele se opõe a dimensão ascendente (os sujeitos estão renascendo pela graça) e central do grupo pertencente à comunidade católica, pautado pela estabilidade passional por meio da configuração patêmica da completude.

A presença do contra-exemplo faz parte da retórica didaticizante desse discurso. A argumentação desse discurso imagético, ao contrapor contra-exemplos à figuras exemplares pode ser relacionada à necessidade proposta pela catequese de ensinar a "amar" e a "temer" a Deus. Temos, portanto, uma manipulação por intimidação. A presença do contra-exemplo a ser rechaçado (não querer ser), valoriza, pelo contraste, os demais sujeitos, tidos como exemplos a serem seguidos (querer ser).

A determinação de uma categoria topológica, própria ao plano de expressão para sua colocação em discurso, permite que possamos estabelecer uma zona central e superior de 
conjunção das linhas (difusão do dom), ao que se oporia uma zona periférica e inferior na qual figurariam sujeitos pautados pela falta patêmica. Desse modo, poderíamos estabelecer o seguinte semi-simbolismo: PE superior/ PC espiritual e PE inferior/ PC material. A superatividade e a inferatividade, na ocupação diagramática do espaço, pode ser relacionada da seguinte forma:

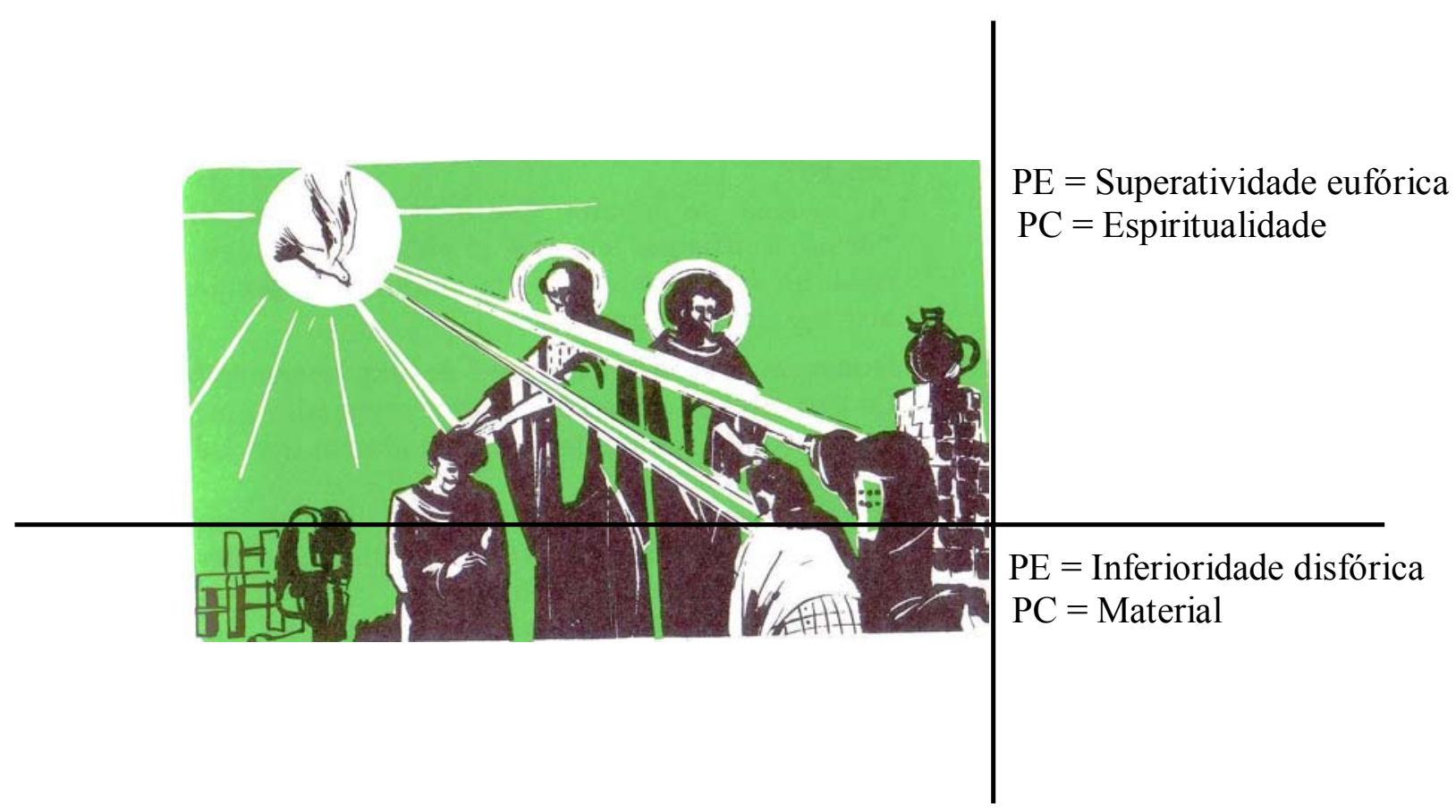

No que diz respeito à enunciação e à perspectiva, podemos atentar para a força da diagonal descendente do núcleo central e superior de conjunção das linhas que ocupa o espaço em que se figurativiza a difusão do dom, realizada pelo Espírito Santo. Essa diagonal descendente suscita uma perspectiva que sugere uma orientação de sentido, definida não mais pela altura e largura determinadas por meio da moldura que limita a imagem didática, mas pelas linhas (difusão do dom). Essas linhas, ao atravessarem perpendicularmente o plano, figurativizam os atores do enunciado; os sujeitos cristãos, que, inicialmente disjuntos do $\mathrm{O}_{\mathrm{v}}$ "graça divina", buscam a sua conjunção por meio da recepção da economia sacramental católica. 


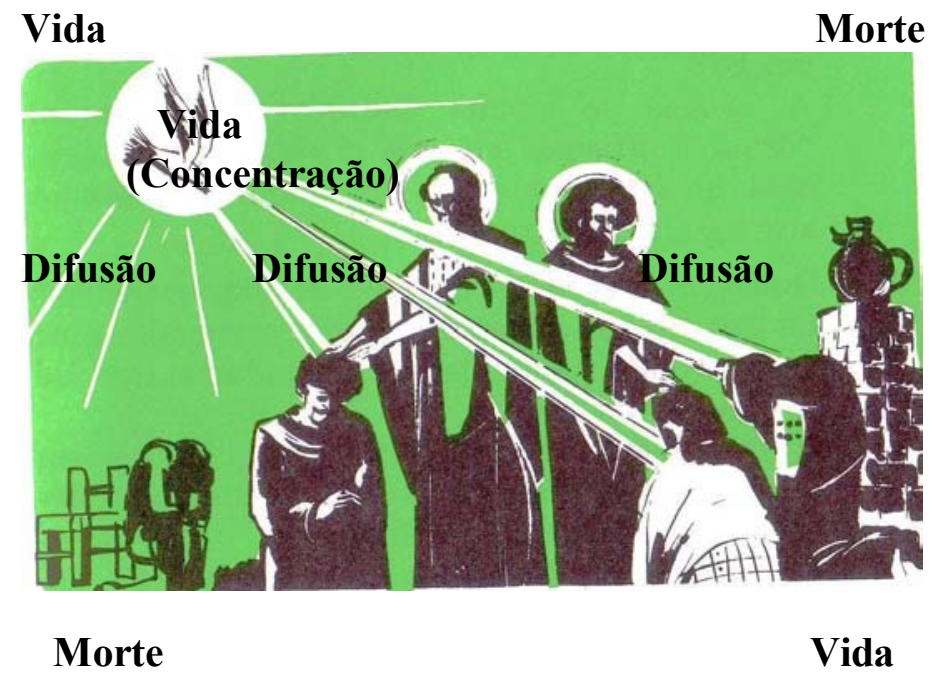

Assim, temos o estabelecimento da seguinte relação semi-simbólica dada por meio do percurso temático difusão do dom:

PC vida/sagrado vs. profano/morte

PE luz vs. sombra.

Desse modo, a difusão dos dons do Espírito Santo, ao veicularem valores sagrados, referentes às crenças, valores e aspirações católicos, representariam em sua difusão a negação dos valores profanos.

As categorias cromáticas, ao operacionalizar possibilidades de combinação de cores, dadas por meio de oposições cromáticas estabelecidas no espaço da tela, propiciam a instalação de movimento e ritmo da cor dentro do espaço do enunciado plástico considerado.

Desse modo, ao observar o cromatismo presente na imagem considerada, verificamos a presença da trilogia verde-branco e preto. Ao tomarmos a luz (difusão do dom) como instância organizadora e delimitadora da forma, obtemos a seguinte relação semi-simbólica: PC vida/ PE claro vs. PC morte/ PE escuro. 
Tomemos, agora, a ilustração didática exemplar presente no final da lição catequética considerada.

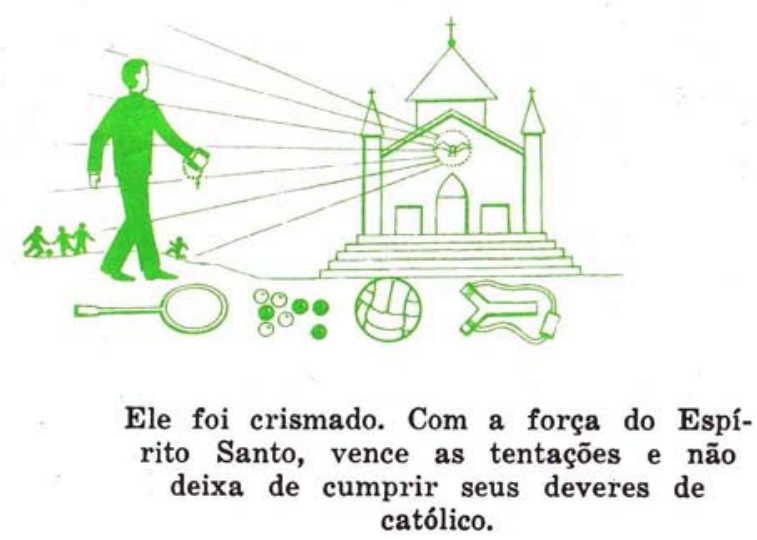

Ilustração 12 SURIAN, Frei Carmelo. Primeiro Catecismo da Doutrina cristã. 145 ed. Petrópolis:Vozes, 2005. p.49.

As relações entre as categorias verbal e visual no enunciado catequético considerado, embora sejam predominantemente constituídas por meio da função de etapa, também apresentam o verbal em função de ancoragem de modo contratual. Esta função de ancoragem contratual dá-se por meio da legenda que acompanha a imagem, na medida em que esta, assim como sugere Barthes (1984), apresenta função de elucidação e explicitação do conteúdo do enunciado visual.

No que diz respeito à ilustração didática exemplar, observa-se a utilização de um PN de uso pautado pela manipulação realizada na ordem de um dever-saber, crer-dever-saber e poder-saber entrar em conjunção com o modo de vida, cuja receita é dada no enunciado do catecismo. Por meio dessa imagem, o PN de uso constitui-se por meio de um didatismo plástico (figurativo) que dita como viver heroicamente como "soldado de Cristo" e que o sujeito, ao cumprir adequadamente sua missão, possa permanecer em comunhão com a Igreja Católica.

Ao observar mais atentamente a imagem verificamos que ela se divide dicotomicamente. Assim, ao estabelecermos uma primeira segmentação da imagem, dada a 
partir da oposição de relações entre elementos visuais, podemos reconhecer a divisão do espaço representado por meio da articulação entre duas unidades discretas: uma parte superior e uma parte inferior. Na parte superior temos a figurativização do percurso da sacralidade, da comunhão com a Igreja Católica; na parte inferior temos a disposição do percurso da materialidade como figurativização das coisas do mundo que são deixadas de lado em prol da Igreja e da conjunção com a "graça divina".

O percurso da materialidade (figurativizado pela raquete, bolas e estilingue), que poderia desviar o sujeito de seus deveres cristãos, coloca-se numa escala superior às demais ilustrações. Esses elementos estão postos em um primeiro plano, desproporcionais à escala da Igreja ao fundo. Institui-se nesse momento uma sanção cognitiva positiva de reconhecimento ao sujeito que segue sua missão apesar das tentações que lhe foram impostas.

Observamos a discrepância das escalas relativas da imagem, com a instituição de pontos de vista misturados, sugerindo a presença de diferentes momentos da enunciação. Com essa discrepância sacrifica-se a verossimilhança do PE em nome de uma "didaticidade" no PC. O privilégio do concebido (PC) sobre o percebido (PE), a que remetemos a maneira de se pintar o que se pensa, não o que se vê, comum aos desenhos feitos por crianças, pode ser observado nessa imagem na discrepância das escalas relativas.

Quanto à forma, que pode ser descrita por meio da categoria eidética homogêneo vs. heterogêneo, podemos opor o percurso do sujeito cristão ao percurso da materialidade (ludicidade). A homogeneidade do percurso do sujeito cristão é dada pela regularidade de seu preenchimento como um todo indissociável. O percurso da ludicidade pode ser associado à forma da heterogeneidade, pela diferença de escala instituída.

Quanto à disposição das figuras, verificamos a presença de planos pela superposição lado a lado das figuras, que estão dispostas em escalas diferenciadas. 
A apreensão da totalidade da imagem dá-se mediante a categoria multiplicidade, por oposição à unidade do núcleo central representado pela Igreja. Quanto ao cromatismo, observa-se a presença da categoria monocromático, na medida em que toda a imagem se compõe por meio do cromatismo verde.

No que diz respeito à observação das categorias topológicas que permeiam a imagem didática considerada, observamos a presença da categoria central vs. marginal.

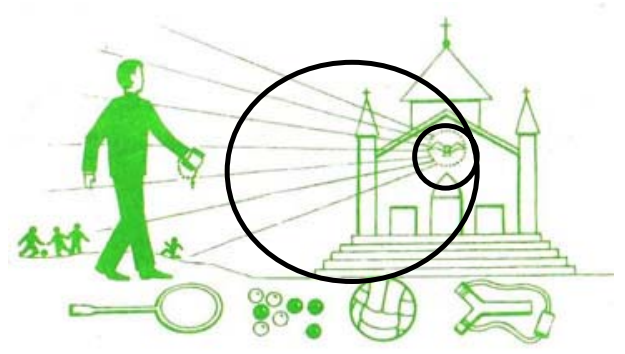

Central vs. marginal

Temos nessa figura a centralidade da iminência do encontro do homem com o Espírito Santo. Por meio dessa categoria configura-se uma sanção pragmática com a recepção pelo "crismado" dos sete dons conferidos pelo Espírito Santo: temor de Deus, piedade, fortaleza, conselho, ciência, inteligência e sabedoria. Esses dons são representados na imagem por meio da difusão das 7 linhas diagonais colocadas em direção ao sujeito.

Por sua vez, a determinação de uma categoria topológica, própria ao plano de expressão para sua colocação em discurso, permite que possamos estabelecer uma zona central e superior de conjunção das linhas (difusão do dom). Assim, notamos a oposição de uma zona periférica e inferior na qual figuraria o percurso da materialidade. Desse modo, poderíamos estabelecer o seguinte semi-simbolismo: PE superior/ PC espiritual e PE inferior/ PC material. No que diz respeito à categoria plástica topológica, temos a sua articulação entre superior (espiritual) e inferior (material). 


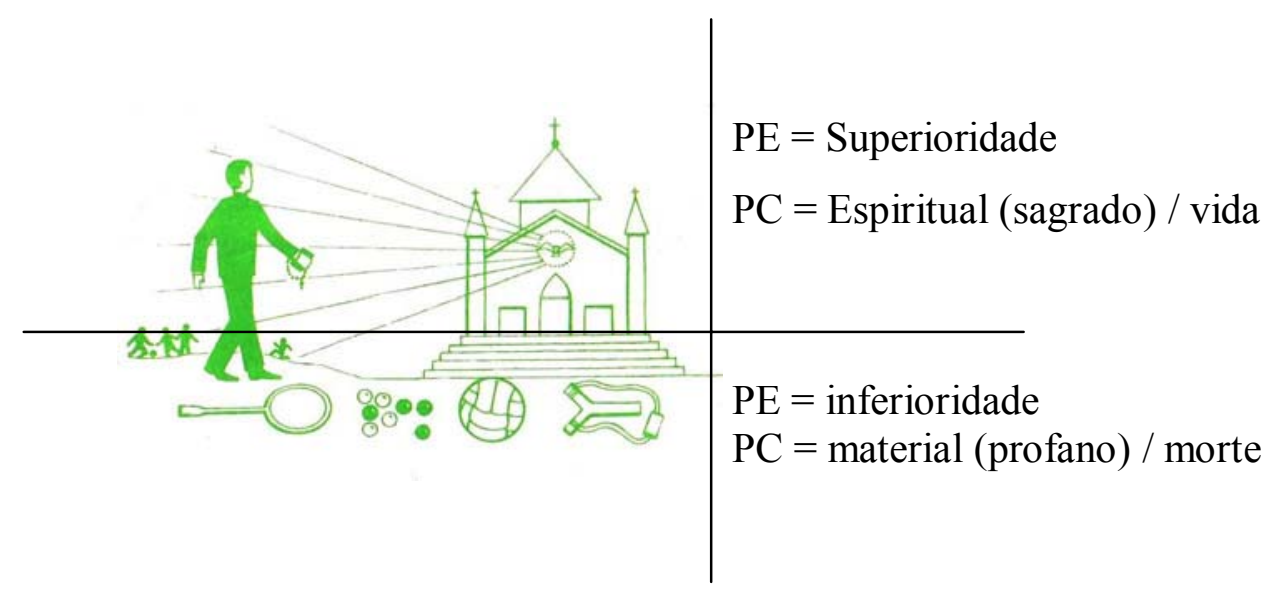

A imagem, ao se constituir no eixo da verticalidade, dispõe como eufórico (alto), além do Espírito Santo, o "crismado", que "com a força do Espírito Santo não deixa de cumprir os seus deveres de católico" (SURIAN, 2005, p. 49). São disforizadas as tentações mundanas que se opõem às práticas católicas, sendo estas dispostas no eixo inferior da imagem (figuras da raquete, das bolas e do estilingue), ou de tamanho reduzido, com a figurativização daqueles que deixam de cumprir os seus deveres católicos (meninos jogando bola).

Essa imagem visual constrói a mesma lógica do contra-exemplar verificada na primeira ilustração didática dessa lição catequética. O contra-exemplo a ser rechaçado (meninos jogando bola), tal como o homem solitário da primeira ilustração didática, está situado no canto esquerdo e em escala menor, distante dos espectadores. Essa problemática dos lados esquerdo vs. direito, retoma o sentido funcional atribuído às mãos e aos lados direito e esquerdo, significando respectivamente "bom" (direito) e "mal" (esquerdo) (cf. TOLSTÓI, 1981, p. 227-230). Vemos, portanto, reiterado no contra-exemplo, a retórica ritual e cultural que estabelece o "esquerdo" como elemento negativo.

Entretanto, a despeito das semelhanças entre as imagens visuais, constrói-se entre elas uma anti-simetria como efeito de didaticidade. Na primeira imagem a figura do contraexemplar é determinada de por um homem solitário, em oposição aos grupo de heróis (figuras exemplares) ungidos pelo Espírito Santo. $\mathrm{Na}$ segunda imagem temos a héxis corporal 
olímpica solitária de um rapaz, em caminho reto em direção ao Espírito Santo, e que se opõe, por sua vez, ao grupo de meninos jogando bola (mau exemplo) ao fundo.

Verificamos, portanto, nessa segunda imagem visual, que a diferença de escala instituída constrói-se mediante a instauração do enunciatário, feixe de expectativas a esse discurso. A disposição da imagem constrói o percurso do olhar do enunciatário. Essa disposição dá a impressão que, quem olha, é quem está no mundo, em disjunção com a graça divina. Como esse catecismo é voltado à catequese para a primeira comunhão, o enunciatário pressuposto, ainda não está crismado. Ele está longe da graça. Já aquele crismado, que vai ao encontro da igreja, é modalizado pelo querer, dever, poder e saber-ser conjunto com os valores propostos. Observamos assim, o caráter exemplar dessa imagem visual, que leva o catecúmeno a querer-ser igual ao crismado figurativizado no enunciado.

Esse desapego à ludicidade, ao profano, que remete à disforização dos baixos não regenerados, recupera a cultura oficial da Idade Média, tal como nos apresenta Bakhtin (1999) durante sua exposição das dimensões da cultura cômica e popular na Idade Média contrapostas à cultura oficial, observada nas formas do culto e nas cerimônias oficiais sérias da Igreja ou do Estado Feudal.

A concepção corporal pautada pela disforização dos baixos não-regenerados, tal como se apresenta na imagem didática da lição do catecismo, mostra-se condizente com a concepção de corpo presente nos cânones literários e plásticos da Antiguidade Clássica.

Assim, os elementos de ludicidade, dispostos numa escala superior às demais ilustrações, se colocariam como obstáculos que se levantariam contra as aspirações do ideal católico. Entretanto, o que o enunciado discursiviza é a sanção pragmática e cognitiva positiva obtida. Desse modo, os elementos de ludicidade, dada a disforização com a qual esse enunciado os caracteriza, não se colocam como obstáculos ao fiel em conjunção com a graça, que, ao não se deixar levar por tentações mundanas, cumpre adequadamente os seus deveres 
de católico. Essa valorização do sacrifício euforiza o herói, ao cumprir adequadamente o contrato proposto.

A semiótica verbal, ao se compor como grafismo, na medida em que podemos analisar as categorias plásticas referentes à sua cor, forma e tamanho da fonte, também pode ser associada a uma semiótica plástica.

Desse modo, ao observar as coerções da materialização plástica referentes ao título da lição e as seções (na liturgia, oração, missão a cumprir e devo guardar para a vida) imediatamente seguintes ao texto em perguntas e respostas, observamos a regularidade e simetria do grafismo. As fontes encontram-se dispostas em caixa alta, com identidade entre sua forma e tamanho, sendo determinadas por meio do monocromatismo verde. Desse modo, observamos a presença de uma identidade cromática entre os caracteres do grafismo do título, seja das seções ou das ilustrações.

Observamos, portanto, uma perspectiva harmoniosa do preenchimento do espaço obtida por meio da presença de um equilíbrio cromático, contraído por meio da trilogia verdebranco-preto e dado nos dois sistemas semióticos, verbal e visual, de que se compõe o enunciado considerado. O mundo da placidez e da serenidade é dado no próprio cromatismo, presente no enunciado por meio das ilustrações e rubricas. O que remete a uma ilusão de equilíbrio que remete, por sua vez, à estética linear (clássica), como uma estética pautada pela desaceleração e codificação de uma realidade que chama a atenção para os gestos em si próprios. A clareza e firmeza dos contornos, a simetria das formas, volumes e cores, somadas à estaticidade do plano do conteúdo, criam a ilusão de um mundo simétrico e ordenado, um mundo em perfeito equilíbrio. Um mundo que se institui por meio de um comportamento idealizado, de uma virtude pautada pelo dever-ser.

As associações realizadas no âmbito semiótico, no que concerne à categoria juntiva da sintaxe narrativa, responsável pelo estabelecimento de relações de conjunção ou disjunção do 
sujeito com o objeto de valor almejado, permitiram que se postulasse a existência dessas relações num nível mais profundo o qual nos remete ao conceito de foria.

As tensões que impelem o sujeito em direção ao objeto, às quais remetemos à protensividade do sujeito e a potencialidade do objeto, resultam da cisão primordial responsável pela necessidade de instauração do fluxo original, cujo objetivo último estaria representado pela recuperação do elo existente entre sujeito e objeto.

A direção que o sujeito assumiria em relação ao objeto seria a representante, no nível tensivo, pela escolha de valores temporais nos quais predominariam as continuidades (euforias) ou descontinuidades (disforias). Esse modo específico de axiologizar valores corresponde aos preceitos de uma determinada formação ideológica, no caso, os valores propugnados pela ideologia religiosos católica, e posteriormente materializados no nível discursivo.

A ideologia religiosa católica faz-se presente por meio da escolha de valores contínuos, responsáveis, no nível subjetal, pelo contrato fiduciário estabelecido pelos actantes destinador e destinatário e, no nível objetal, pela crença e adesão do catecúmeno aos conteúdos da fé, moral e práticas cristãs. Os valores descontínuos, não prescritos e, conseqüentemente, transgressores da crença e moral católicas e de tendência disforizante, correspondem ao percurso da ludicidade dos valores profanos, representados no nível narrativo por meio do PN implícito do anti-sujeito (demônio e más inclinações). Este PN implícito poderia fazer com que o sujeito interrompesse o fluxo fórico de busca ao objeto valor "graça divina" ao deixar de cumprir os seus deveres de católico e se deixar levar por tentações mundanas.

Retomemos, inicialmente, a noção de ritmo na perspectiva de uma semiótica tensiva.

Antes de dar seguimento à tentativa de definição rítmica da lição catequética considerada, e dado que a noção de ritmo é essencial à apreensão ritual, notadamente à 
liturgia da Igreja Católica, estabeleceremos breves considerações a respeito da ritualística religiosa com base em Durkheim (2003) e Greimas e Courtés (1986, p.189).

Durkheim (2003), ao proceder à definição do fenômeno religioso em seu conjunto, estabelece a sua classificação em duas categorias fundamentais: a crença e o rito. Ao passo que crença pode ser concebida como representação, estado de opinião, o rito é concebido como uma prescrição, ou seja, como maneiras de agir para que o sujeito possa fazer parte de uma determinada comunidade religiosa.

Uma religião é um sistema solidário de crenças e práticas relativas a coisas sagradas, isto é, separadas, proibidas, crenças e práticas que reúnem numa mesma comunidade moral, chamada igreja, todos aqueles que a elas aderem. (DURKHEIM, 2003, p. 32).

Durkheim (2003) caracteriza o fenômeno religioso por meio do estabelecimento do plano dicotômico que dispõe como antagônicas as noções de sagrado e profano. Cabe à ritualística religiosa, notadamente por meio dos ritos de iniciação, realizar a mudança de estado do sujeito, para que este possa sair do mundo dito "profano" e inscrever-se no pólo do "sagrado".

O rito pode ser então compreendido como "uma série de comportamentos regrados e recorrentes" (GREIMAS; COUTÉS, 1986, p. 189). O rito, ao ser suscetível a uma análise narrativa, configura-se como práticas manipulatórias para a construção da competência do sujeito, um aspecto transformador visando um fazer-fazer.

Desse modo, tendo essas concepções em mente e, ao tomarmos como base as definições de Zilberberg (1992) em Présence de Wölfflin, realizaremos a análise dos funtivos do andamento que perpassam o discurso do catecismo considerado.

"Jesus nos faz seus soldados", tal como pode-se notar por meio da análise que realizamos de seu nível narrativo, ao expor a doutrina católica com o rito de iniciação cristã da crisma apresentada em seu enunciado, prescreve uma série de comportamentos regrados e 
recorrentes, que devem ser realizados pelo sujeito para que ele possa se manter em conjunção com o objeto-valor "graça divina".

Ao se constituir por meio da modalidade do dever-ser e dever agir de acordo com o modo de vida, cuja receita é dada no próprio enunciado, o catecismo apresenta uma percepção orientada pelo pólo do sagrado.

$\mathrm{O}$ sujeito, já conjunto com o $\mathrm{O}_{\mathrm{v}}$ "graça divina", receberá o $\mathrm{O}_{\mathrm{m}}$ "poder ter o poder e força para resistir aos assaltos da tentação". Um sujeito que ao agir conforme as prescrições permanecerá conjunto com tais valores.

O PN estabelecido pelo destinador-manipulador, para que o sujeito permaneça conjunto com tais valores corresponde ao fazer emissivo, que também poderíamos denominar continuativo, por nele privilegiarmos a dominância da temporalidade emissiva (parada da parada), responsável pelas experiências conjuntivas pautadas pela extensão, duração e apreensão do percurso de busca do $\mathrm{O}_{\mathrm{v}}$ "graça divina" empreendido pelo sujeito. $\mathrm{O}$ antiprograma, realizado de modo implícito pelo anti-destinador (demônio e más inclinações), corresponde ao fazer remissivo, à parada, ao qual remetemos ao conceito de surpresa, responsável pela ruptura da relação contratual entre destinador e destinatário e pela interrupção do fluxo fórico.

Temos ao longo do texto a presença do destinador-manipulador tentando fazer com que o sujeito não pare, que o sujeito siga seu curso de restabelecimento da cisão original, tanto no que concerne à categoria verbal quanto à visual. Desse modo, o destinadormanipulador tenta assegurar a diretividade da direção estabelecida pelo âmbito contratual da fé, e para isso faz uso de modulações de velocidade.

Ao tomarmos como base que as escolhas dos valores tensivos, realizados pela instância pressuposta do sujeito da enunciação desde as etapas mais profundas do modelo, 
pressupõem também a escolha de modulações de velocidade, nos transportamos ao domínio do andamento.

Toda ruptura pressupõe como coeficiente tensivo a alta velocidade, que poderia ocasionar a cisão do próprio sujeito e dos laços que o ligam ao sistema de valores considerado. Assim, para evitar a fratura da identidade entre sujeito e objeto e, conseqüentemente, a fratura do sistema de valores representado pela ideologia religiosa católica, o enunciador procede ao estabelecimento do prolongamento da relação conjuntiva ao que nos remete a uma experiência conjuntiva pautada pelo andamento desacelerado.

\begin{abstract}
A desaceleração faz a duração durar de modo a dar tempo ao tempo. Por mais desconfortável que esteja a situação do sujeito, se este puder graduar seu tempo de acordo com certa programação, estabelecendo uma ordem de espera, é provável que obtenha as condições mínimas de segurança para conduzir seus passos seguintes. (TATIT, 2001, p. 117)
\end{abstract}

O domínio da religião não deseja que o objeto seja partido, para isso o crer faz uso do nível emissivo. As atividades míticas ou religiosas, devido a sua função pragmática, constituem-se como atividades desaceleradas e dessemantizadas. Como o rito não pode ter como pressuposto a categoria surpresa, configura-se nesse discurso a opção pela parada da parada que visa segurar o tempo e fazer com que ele não se mova tão rápido. Esse momento, desacelerado diante do mundo, constitui a presença de práticas para que o sujeito, ao se sentir o "senhor de seu próprio tempo", tenha as suas expectativas cumpridas.

Desse modo, o compromisso do enunciador catequético com os valores extensos, emissivos e pelo andamento desacelerado reflete o receio da velocidade e da interrupção brusca que, ao serem ocasionados pelo anti-PN (demônio e más inclinações), certamente, ocasionariam uma fratura no próprio ser e nos laços que o tornariam unido ao sistema religioso considerado. 
Tomaremos como base o estudo estabelecido por Zilberberg (1992) intitulado Présence de Wölfllin. Nele, Zilberberg (1992), ao discorrer sobre a tipologia elaborada por Heinrich Wölfllin para a compreensão dos modelos estéticos do Renascimento e do Barroco, tratados comparativamente, estabelece a análise da percepção do ator da enunciação próprio às estéticas consideradas.

A arte da Renascença é dada como a "arte da beleza passiva", cuja direção afetiva é pautada pela "serenidade", um andamento infinitamente lento e uma expansão indefinida. A arte barroca é caracterizada por sua inquietude, pautada pela "concentração" e fugacidade.

$\mathrm{Na}$ arte clássica, um andamento infinitamente lento faz surgir seu inverso, uma expansão indefinida, ao passo que para o barroco um andamento infinitamente vivo transforma a expansão em concentração e tolera apenas o infinitamente breve. Aqui concentração e fugacidade, lá expansão e solenidade (ZILBERBERG, 1992, p. 108).

Dessa forma, o enunciado do catecismo, seja no que concerne à substância plástica ou à substância verbal, pode ser associado, predominantemente à estética clássica (linear). Interlocutor e interlocutário são figurativizados de maneira extensa, o objeto desejável e possível coloca-se a distância do olhar plácido do observador, que é caracterizado pela apreensão do processo.

O mundo da placidez, da serenidade, é dado no próprio enunciado, o que remete a uma ilusão de equilíbrio que remonta à estética clássica, como uma estética pautada pela expansão, desaceleração e codificação de uma realidade que chama atenção para os gestos em si próprios. A estética clássica condiz com a liturgia cerimonial da Igreja católica, pautada pela desaceleração e andamento lento, visando à parada da parada e a codificação de gestos ritualísticos que chamam a atenção para si mesmos (Ex: a imposição das mãos). A presença de contornos bem definidos e a simetria das formas, volumes e cores configuram uma direção 
de apreensão definida e dominada pela parada da parada dentro do discurso católico considerado.

Outro aspecto que pode ser considerado, por meio dessa tentativa de aproximação entre a estética clássica e o enunciado do catecismo católico, refere-se ao esquema de visão. Assim, o catecismo considerado, ao instaurar em suas ilustrações didáticas as figuras de acordo com a perspectiva enunciva (os rostos sempre estão dispostos de perfil) associada à duração dos gestos cerimoniais, pode ser associado ao esquema de visão imóvel e contemplativo dos gestos e atitudes concernentes à ritualística católica (cf. ilustração 1Ilustração da História Bíblica em que se baseia a lição). Um ponto de vista estático que representa a gravidade dos gestos religiosos pautados pela lentidão e duração, próprios à estética clássica.

Entretanto, apesar da dominância de traços clássicos no enunciado catequético, devemos nos ater à presença de elementos barroquizantes, tal como a topologia diagonal descente na difusão e projeção dos dons do Espírito Santo (cf. Ilustração didática 1 Ilustração da História Bíblica em que se baseia a lição).

Observamos, assim, a presença de uma iconografia chapada, sem profundidade, sem movimento, pois ao ser constituída como representativa do sagrado, deve evocar a plenitude do ser. Estamos, portanto, em um regime de expansão pautado pelo andamento lento e desaceleração. Um pólo orientado pela parada da parada, pelo ordenamento tranqüilo e percepção do movimento. Configurando um esquema de visão imóvel e contemplativo do sujeito pautado pela suficiência e pela ilusão de bem estar geral, o que caracteriza uma percepção sacralizada, uma percepção orientada pelo pólo do sagrado.

Após as analises realizadas podemos definir o éthos do ator da enunciação do Primeiro Catecismo da Doutrina Cristã. 
No que diz respeito ao estilo, o éthos característico do gênero catecismo, depreendemos do texto um tom de voz altivo, autoritário e detentor de uma verdade inquestionável. Respaldado pela autoridade das Sagradas Escrituras, e pelo poder conferido a esse enunciador, figura mediadora entre Cristo e os fiéis, e, portanto, aquele que tem o poder e o saber para doutrinar e ensinar em matéria religiosa. Tem por fím último a crença e a obediência na palavra, tal como apregoada pela ideologia católica inspirada pelas Sagradas Escrituras e a conseqüente adesão pela fé aos dogmas propostos. Assim, o modo próprio do enunciador do catecismo busca a adesão de sua imagem pelo enunciatário proposto a esse discurso, que deve, por conseguinte, partilhar das crenças e valores propostos pelo catolicismo.

O Primeiro Catecismo da Doutrina Cristã. (São Paulo: Vozes, 2005) confirma o éthos prévio dado pelo gênero catecismo, como manual de instrução elementar da fé cristã.

No que diz respeito ao enunciado do catecismo, na lição considerada, observa-se a construção da predominância de uma imagem dada por meio do simulacro de uma totalidade discursiva autocentrada, pautada pela ilusão de um saber teoricamente sustentado. A imposição de dogmas pautados pela sustentabilidade dada na ordem da certeza, do indubitável, contribui para o engessamento desse discurso, construído por meio do simulacro de monofonia, apesar da aparente polifonia. A aparente polifonia se dá por meio da instauração das perguntas retóricas, com a instauração de duas vozes no modo da mentira, e de um enunciado asséptico da cenografia fundadora.

A exploração semântica da cena fundante, pautada pela exploração dogmática, apresenta como resultante o assoberbamento do agente religioso (Igreja Católica) e o encolhimento da cena fundadora, fonte e fiadora desse discurso. Desse modo, o simulacro de racionalidade, obtido por esse autocentramento, é dado na própria estrutura textual por meio da escolha do tipo textual injuntivo e da instauração das perguntas retóricas, pois a 
demonstração da idéia de sequencialização, que confere uma dimensão ordenada a esse discurso, imprime aos argumentos uma direção ordenada e a imagem do raciocínio perfeito.

Assim, mediante a exposição realizada, pode-se definir o éthos católico com um éthos "marmóreo" de tom de voz didático e professoral. Um éthos da certeza, de corporalidade ereta, autocentrada, pautada pelo imobilismo, pelo equilíbrio e que constrói de si e para si a imagem do detentor do saber impresso no próprio discurso do catecismo. Um éthos que se apóia numa relação de assimetria da relação entre poder e saber de E1 (catequista) e E2 (catecúmeno), apresentando-se como um texto injuntivo pautado por prescrições, num texto disposto em perguntas e respostas pautado pela progressão lógica, em que não se admitem reflexões. Ao que podemos remeter ao páthos, ao leitor instituído como feixe de expectativas a esse discurso.

Tomemos para tanto a noção de "incorporação" estabelecida por Maingueneau (2005b, p. 72): "Falamos de incorporação para designar a maneira pela qual o co-enunciador se relaciona ao éthos de um discurso".

Sua forma composicional pautada pela exposição breve e direta da doutrina católica, condiz com a imagem do enunciatário pressuposto a esse discurso. Um leitor que quer aprender os fundamentos católicos de forma breve e direta por meio de um conteúdo revestido de facilitação, que não deixe dúvidas. 


\section{Publicação de estudo bíblico infanto-juvenil (Testemunha de Jeová): Meu Livro de}

\section{Histórias Bíblicas.}

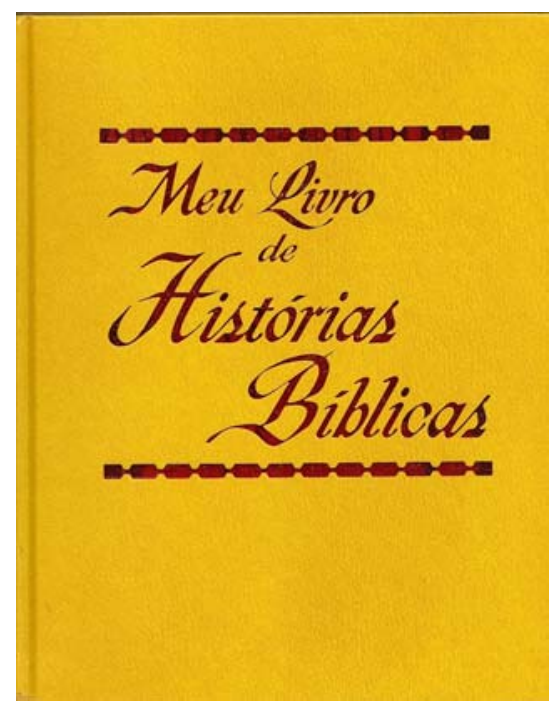

Ilustração 13 Capa do MEU LIVRO de Histórias Bíblicas. São Paulo: Sociedade Torre de Vigia de Bíblias e Tratados, 1978.

No que concerne aos textos instrucionais voltados para o público infantil, levaremos em consideração a unidade recortada: "Davi e Golias", que se encontra presente no livro denominado Meu Livro de Histórias Bíblicas, pertencente à esfera de circulação das atividades institucionalizadas da prática religiosa das Testemunhas de Jeová.

Na tentativa de delinearmos o modo de presença do éthos do ator da enunciação como tom, voz, caráter e corporalidade da unidade (unus) considerada para análise, devemos levar em conta a totalidade (totus), da qual fazem parte as seguintes seções:

a) A capa e o título do livro instrucional: Meu Livro de Histórias Bíblicas;

b) A Advertência:

As citações da Bíblia, neste livro, são parafraseadas. São expressas em linguagem simples, para que as crianças possam entender o sentido delas. Os 
textos mencionados no fim de cada história indicam a fonte bíblica (MEU LIVRO de histórias bíblicas, 1978).

c) A Apresentação: Meu Livro de Histórias Bíblicas

Este é um livro de histórias verídicas. São tiradas do maior livro do mundo, a Bíblia. Contam a história do mundo desde quando Deus começou a criar, até os nossos dias. Falam até mesmo sobre o que Deus promete fazer no futuro. Este livro dá uma idéia do que é a Bíblia. Fala sobre as pessoas da Bíblia e sobre o que elas fizeram. Mostra também a maravilhosa esperança de vida eterna, numa terra paradisíaca, que Deus oferece às pessoas.

Há 116 histórias neste livro. Elas são agrupadas em oito partes. Uma página, no começo de cada parte, diz em poucas palavras o que se encontra nela. As histórias são contadas na ordem em que os acontecimentos ocorreram. Isto lhe ajudará a saber quando as coisas aconteceram na História com relação a outros eventos.

As histórias são contadas em linguagem simples. Muitos de vocês, crianças, poderão lê-las sozinhas. Vocês, pais, verificarão que seus filhos menores terão muito prazer em que lhes leiam estas histórias vez após vez. Verão que este livro contém muita coisa interessante, tanto para os mais jovens como para os mais velhos.

No fim de cada história fornecem-se as referências bíblicas. Exortamo-lo a ler estes trechos da Bíblia em que as histórias se baseiam (MEU LIVRO de Histórias Bíblicas, 1978).

d) Exposição de 116 narrativas bíblicas, agrupadas em oito partes, seguindo a ordem em que se apresentam na Bíblia:

Parte 1. Desde a criação até o dilúvio;

Parte 2: Desde o dilúvio até a libertação do Egito;

Parte 3: Desde a libertação do Egito até o primeiro Rei de Israel;

Parte 4: Desde o primeiro Rei de Israel até o cativeiro em Babilônia;

Parte 5: Desde o cativeiro em Babilônia até a reconstrução dos muros de Jerusalém;

Parte 6: Desde o nascimento de Jesus até a sua morte;

Parte 7: Desde a ressurreição de Jesus até a prisão de Paulo;

Parte 8: O que a Bíblia diz se cumpre. 
e) A narrativa bíblica considerada, para que se tenha idéia do suporte, será reproduzida a seguir:

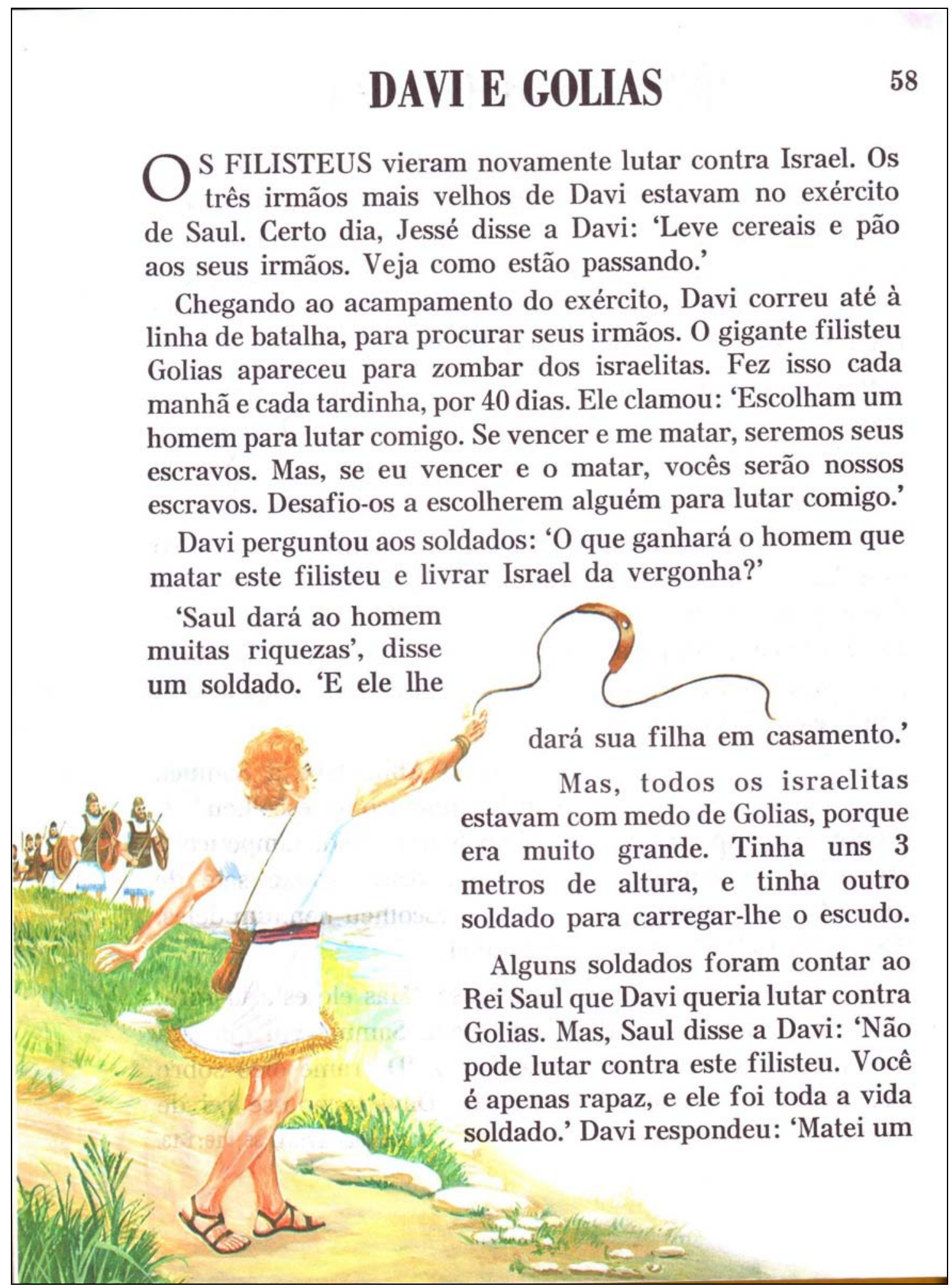

Ilustração 14. MEU LIVRO de Histórias Bíblicas. São Paulo: Sociedade Torre de Vigia de Bíblias e Tratados, 1978. História 58. 
urso e um leão que haviam levado ovelhas de meu pai. E este filisteus será como um deles. Jeová me ajudará.' Saul disse então: 'Vá, e Jeová esteja com você.'

Davi desceu a um riacho para apanhar cinco pedras lisas, que pôs na sua bolsa. Depois tomou a funda e foi ao encontro do gigante. Vendo-o Golias, quase não acreditou. Achou que era fácil matar Davi.

'Venha para cá', disse Golias, 'e eu vou dar seu cadáver às aves e a os animais'. Mas, Davi disse: 'Você vem a mim com espada, lança e dardo, mas eu o enfrento no nome de Jeová. Hoje, Jeová entregará você na minha mão e eu o abaterei.'

Então, Davi correu para Golias. Tirou uma pedra da bolsa, colocou-a na funda e atirou-a com toda a força. A pedra atingiu Golias bem na cabeça, e ele caiu morto! Vendo os filisteus que seu campeão havia caído, todos fugiram. Os israelitas correram atrás deles e venceram a batalha.

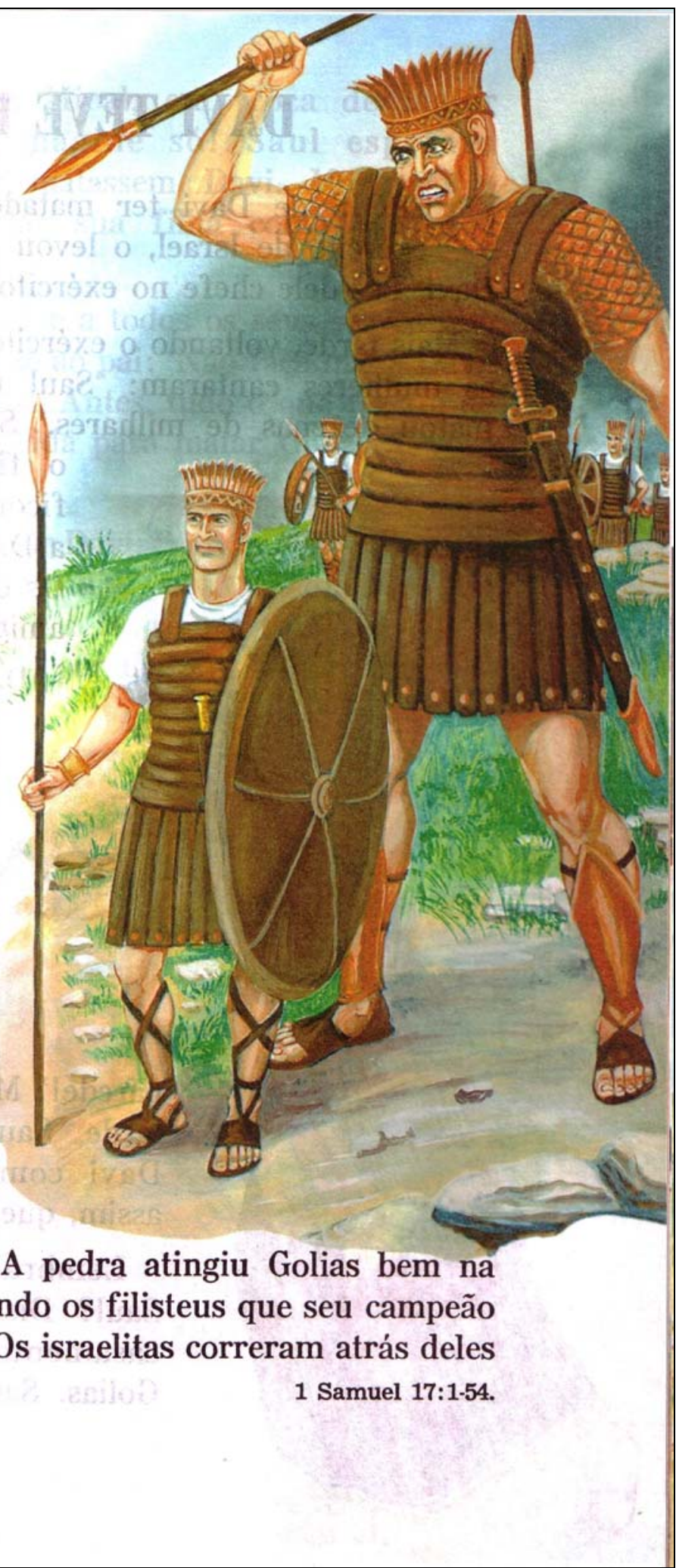

Ilustração 15. MEU LIVRO de Histórias Bíblicas. São Paulo: Sociedade Torre de Vigia de Bíblias e Tratados, 1978. História 58. 
Assim, no que concerne à coerção genérica de sua exposição, o enunciado considerado apresenta a seguinte estrutura em todas as histórias bíblicas que o constituem: a) título da lição colocado em maiúsculas, seguido do respectivo número da história considerada; b) história Bíblica realizada de modo parafrástico; c) ilustrações didáticas da história bíblica em cores; d) referências bíblicas dadas no final de cada história.

Como forma de auxílio ao estudo de Meu Livro de Histórias Bíblicas (1978), o enunciado sugere, como recurso didático, a utilização de perguntas que encerram o enunciado considerado:

\section{História 58 \\ Davi e Golias}

1. Como Golias desafia o exército israelita?

2. Qual é o tamanho de Golias, e que recompensa o Rei Saul promete ao homem que o matar?

3. O que Davi responde quando Saul the diz que ele não pode lutar contra Golias porque é apenas um rapaz?

4. Ao responder a Golias, como Davi mostra sua confiança em Jeová?

5. Como você pode ver na gravura, o que Davi usa para matar Golias, o que acontece aos filisteus depois disso?

Perguntas adicionais:

1. Leia 1 Samuel 17:1-54

(a) Qual era o segredo da coragem de Davi, e como podemos imitá-la? (1 Sam. 17:37, 45; Efé. 6:10, 11)

(b) Por que os cristãos devem evitar um espírito competitivo como o de Golias quando participam de jogos ou de outro tipo de recreação? (1 Sam. 17:8; Gal. 5:26; 1 Tim. 4:8)

(c) Como as palavras de Davi indicam que ele tinha fé no apoio de Deus? (1 Sam. 17:45-47; 2 Crô. 20:15)

(d) Em vez de descrever uma simples competição entre exércitos inimigos, como esse relato mostra que a batalha na verdade era entre os deuses falsos e o verdadeiro Deus, Jeová? (1 Sam. 14:43, 46 e 47)

(e) Como o restante ungido imita o exemplo de Davi de confiar em Jeová? (1 Sam 17:37; Jer. 1:17 - 19; Ver. 12:17) (MEU LIVRO de Histórias Bíblicas. São Paulo: Sociedade Torre de Vigia de Bíblias e Tratados, 1978. História 58.)

Desse modo, observamos que o livro instrucional considerado (MEU LIVRO de

Histórias Bíblicas. São Paulo: Sociedade Torre de Vigia de Bíblias e Tratados, 1978) 
confirmará o éthos prévio dado pelo gênero livro de histórias bíblicas, ao se apresentar como um discurso instrucional e propagador da doutrina das Testemunhas de Jeová.

Este livro apresenta, como elementos constitutivos de sua temática, a doutrina neocristã das Testemunhas de Jeová por meio da exposição do conteúdo presente nas Sagradas Escrituras.

O livro apresenta, também, como coerção genérica, a exposição de 116 narrativas bíblicas agrupadas em oito partes, seguindo a ordem de seus acontecimentos, tal como consta nas Sagradas Escrituras. As citações da Bíblia encontram-se parafraseadas e as fontes bíblicas, das quais as histórias foram extraídas, são dadas por meio de uma indicação no final de cada história.

O enunciado de Meu Livro de Histórias Bíblicas caracteriza-se, portanto, qual um texto narrativo ao se constituir como um texto figurativo, pautado pela progressão temporal e reduplicação mítica do discurso fundador. Apresenta uma série de mudanças de situação e transformação de estado operacionalizadas por personagens determinadas, num tempo e espaço também determinados.

O termo narrativa é utilizado para designar o discurso narrativo de caráter figurativo (que comporta as personagens que realizam ações). Como se trata aí do esquema narrativo (ou de qualquer de seus segmentos) já colocado em discurso e, por isso, inscrito em coordenadas espácio-temporais, alguns semioticistas definem a narrativa - na esteira de V. Propp - como uma sucessão temporal de funções (no sentido de ações). Assim concebida de maneira muito restritiva (como figura temporal), a narratividade não concerne senão a uma classe de discursos (GREIMAS; COURTÉS, 1986, p. 294).

No que concerne aos recursos argumentativos empregados pelo enunciado instrucional para divulgar e legitimar a autoridade da cena fundante, observamos a utilização de uma estratégia discursiva diferenciada da utilizada pelo enunciado catequético infanto-juvenil. Ao contrário do catecismo considerado, que apresenta a prescrição realizada de modo explícito 
por meio da utilização de lições, Meu livro de histórias Bíblicas estabelece a prescrição no modo do segredo, ao operar com a utilização de narrativas exemplares. É o caso da narrativa de "Davi e Golias", ao operacionalizar um texto narrativo pautado pela progressão temporal e reduplicação mítica do discurso fundador, no caso, o livro bíblico de Samuel (1 Samuel 17:1$54)$.

Esse procedimento argumentativo pode ser denominado semioticamente, segundo Bertrand (2003, p. 216), como "raciocínio figurativo":

Trata-se de uma forma de argumentação que, ao contrário da racionalidade dedutiva e demonstrativa que articula causas e conseqüências, hierarquias, relações lógicas entre as partes e o todo, etc., funciona por analogia direta ou, por assim dizer, lateralmente (BERTRAND, 2003, p. 216).

O caráter exemplar dessa narrativa bíblica permite que aproximemos sua estrutura tanto do mito, quanto do gênero conto maravilhoso infantil.

Entretanto, embora conto e mito possam apresentar características que os aproximem, dados os pontos de confluência entre mito e conto, de acordo com Discini (2004a, p.140), convém que estabeleçamos uma diferenciação entre eles.

Não se confundem, entretanto, mito e conto. Mieletínsk (1979, p. 53), apesar de citá-los numa "única zona de difusão de cultura arcaica", aponta "diferenças notáveis" entre eles, por meio das oposições: "sagrado/profano; autenticidade rigorosa/não-rigorosa; destino cósmico, coletivo/familiar, individual; tempo pré-histórico/indeterminado" (DISCINI, 2004a, p. 140).

Desse modo, o enunciado do texto instrucional das Testemunhas de Jeová apresenta uma narrativa mítico-exemplar que leva o crente a querer-ser o ator do enunciado Davi, tido como modelo de conduta a ser seguida.

De acordo com Fiorin (2002, p. 34), o estatuto veridictório de um texto é determinado por meio da convenção fiduciária estabelecida entre enunciador e enunciatário. Esse estatuto 
veridictório explica-se mediante a crença e valores partilhados entre os actantes da enunciação. A história de "Davi e Golias" é verdadeira para os que partilham da mesma formação ideológica cristã e ficcional àqueles que dela não partilham.

Segundo Campbell (2005, p. 131), é freqüente a presença de histórias de heróis na mitologia:

\begin{abstract}
Mesmo nos romances populares, o protagonista é um herói ou uma heroína que descobriu ou realizou alguma coisa além do nível normal das realizações ou de experiência. O herói é alguém que deu a própria vida por algo maior que ele mesmo (CAMPBELL, 2005, p. 131).
\end{abstract}

Se tomarmos como base os procedimentos argumentativos, concernentes às ligações que fundam a estrutura do real, estabelecidos por Perelman e Olbrechts-Tyteca (2005, p. 413), no que diz respeito ao fundamento pelo caso particular, a estratégia argumentativa empregada é a argumentação pelo exemplo.

Davi, um caso particular, é estabelecido como um exemplo, um modelo de conduta a ser imitada. Segundo Perelman e Olbrechts-Tyteca (2005, p. 414), para que alguém sirva de modelo "é porque possui, portanto, certo prestígio", dado que o modelo glorificado é posto a imitação de todos.

Podem servir de modelo pessoas ou grupos cujo prestígio valoriza os atos. $\mathrm{O}$ valor da pessoa, reconhecido previamente, constitui a premissa da qual se tirará uma conclusão preconizando um comportamento particular. Não se imita qualquer um; para servir de modelo, é preciso um mínimo de prestígio. [...] O modelo indica a conduta a seguir; serve também de caução a uma conduta adequada (PERELMAN; OLBRECHTS-TYTECA, 2005, p. 413414).

O comportamento de Davi é exemplar por constituir um simulacro intersubjetivo demonstrado em relação a Jeová. Davi poderia oscilar, poderia duvidar, porém ele não oscila, ele não duvida em nenhum momento. Ele obteve a vitória e salvação, pois era detentor da 
graça. Ele acreditou e tinha confiança no poder que lhe foi atribuído pelo contrato fiduciário demonstrado em relação a Deus.

Davi, na narrativa bíblica considerada, é posto como modelo pelo exemplo, ao passo que Golias constitui-se como o antimodelo de conduta a ser seguida. "Se a referência a um modelo possibilita promover certas condutas, a referência a um contraste, a um antimodelo permite afastar-se delas" (PERELMAN; OLBRECHTS-TYTECA, 2005, p. 417).

Golias é instaurado como o anti-exemplo, o modelo de conduta a ser rechaçada. De acordo com a Nova Enciclopédia Barsa (2001, p. 103) e Brandão (1993, p. 464- 465), a origem dos gigantes remonta à mitologia grega. $\mathrm{O}$ tema da gigantomaquia, ou luta contra gigantes, apresenta sua aparição, principalmente na arte helenística, representando uma espécie de personificação simbólica do triunfo sobre a inteligência, ou do dom divinamente inspirado e, no caso da narrativa considerada, contra a força bruta.

\begin{abstract}
A Gigantomaquia, quer dizer, a luta dos gigantes, foi muito aproveitada na arte grega, sobretudo para ornamentar os frontões dos templos. Seres ctônios, os Gigantes simbolizam o predomínio das forças nascidas da Terra, por seu gigantismo material e indigência espiritual. Imagem da hýbris, do descomedimento, em proveito dos instintos físicos e brutais, renovam a luta dos Titãs. A evolução da vida para uma espiritualização crescente e progressiva é o verdadeiro combate dos "gigantes". Esta evidência implica, todavia, num esforço próprio do homem, que não pode contar apenas com a forças do alto, para triunfar das tendências involutivas e regressivas que lhe são imanentes. O mito dos Gigantes é um apelo ao heroísmo humano. $\mathrm{O}$ Gigante representa tudo quanto o homem terá de vencer pra liberar e fazer desabrochar a sua personalidade (BRANDÃO, 1993, p. 465).
\end{abstract}

Os gigantes, como personagens que fazem parte do imaginário folclórico, também são personagens que habitam a Idade Média. A figura mítica do Gigante na Idade Média aparece representada como um ator que desafia a razão.

Desse modo, tendo essas concepções em mente, tomemos as proposições de Bakhtin $(1999,2005)$, ao considerar a presença dos gigantes como item de carnavalização. Durante o estudo realizado por Bakhtin (1999), referente à obra de Rabelais, no que concerne à mística 
do inferno, observamos, dentre as figuras apresentadas pelo autor como elementos do carnaval, a figura do gigante.

A figura do gigante é dada "por seu corpo grotesco, o que por hora pode ser entendido como afastado da estética realista e naturalista, naquilo que ela tem de inacabamento e estaticidade" (DISCINI, 2006a, p. 54).

Desse modo, observamos a presença da figura do gigante dada segundo o limiar, ao tomar a projeção da dicotomia limite-limiar como segunda acepção carnavalesca. Essa dicotomia, ao firmar o descomedimento, dado em proveito de traços físicos brutais, justifica a “excepcionalidade e inacabamento da apresentação" (DISCINI, 2006a, p. 54).

Assim, observamos que o caráter exemplar dessa narrativa, em conformidade com o sistema de restrições semânticas da formação discursiva considerada, faz com que a narrativa de "Davi e Golias", ao invés de descrever uma simples competição entre exércitos inimigos, apresente a batalha entre deuses falsos e verdadeiros. O que confirma e conclama Davi como herói mítico a ser seguido, uma vez que este é o portador do poder e coragem atribuídos pelo verdadeiro Deus: Jeová.

Observemos, notadamente, por meio da apresentação do referido enunciado, a caracterização do auditório instituído por esse discurso.

Vejamos como Perelman e Olbrechts-Tyteca (1996, p. 22) procedem à definição da caracterização do auditório considerado como uma construção sistematizada pelo orador (páthos):

O auditório presumido é sempre, para quem argumenta, uma construção mais ou menos sistematizada. Pode-se tentar determinar-lhe as origens psicológicas ou sociológicas; o importante, para quem se propõe persuadir efetivamente indivíduos concretos, é que a construção do auditório não seja inadequada à experiência. [...]

A argumentação efetiva tem de conceber o auditório presumido tão próximo quanto o possível da realidade. Uma imagem inadequada do auditório, resultante da ignorância ou de um concurso imprevisto de circunstâncias, 
pode ter as mais desagradáveis conseqüências (PERELMAN; OLBRECHTS-TYTECA, 1996, p. 22).

Considera-se, assim, este enunciado adequado a um público infantil que necessitaria, portanto, de um conteúdo revestido de facilitação e explicitação, um conteúdo que parecesse transparente e não suscitasse dúvidas. Uma versão simplificada, que ao se constituir por meio de um estilo pautado pela utilização de uma linguagem simples, é constitutiva de um recurso didático para maior aproximação do público considerado e maior assimilação da doutrina revelada.

Antes de realizar a análise da unidade recortada, tomemos as alusões intertextuais a que a história bíblica considerada faz referência.

17 E os filisteus foram reunir seus acampamentos para a guerra. Quando se haviam reunido em Socó, que pertence a Judá, então passaram a acampar-se entre Socó e Azeca, em Efes-Damim. ${ }^{2}$ Quanto a Saul e aos homens de Israel, reuniram-se e passaram a acampar-se na baixada de Elá, e foram pôrse em formação de batalha para enfrentar os filisteus. ${ }^{3} \mathrm{E}$ os filisteus estavam parados no monte deste lado e os israelitas estavam parados no monte daquele lado, com o vale entre eles.

${ }^{4} \mathrm{E}$ começou a sair do acampamento dos filisteus um campeão, cujo nome era Golias, de Gate, tendo a altura de seis côvados e um palmo. ${ }^{5} \mathrm{E}$ havia na sua cabeça um capacete de cobre e ele estava vestido de uma cota de malha, de escamas imbricadas, e o peso da cota de malha era de cinco mil siclos de cobre. ${ }^{6} \mathrm{E}$ havia grevas de cobre acima dos seus pés e um dardo de cobre entre os seus ombros. ${ }^{7} \mathrm{E}$ a haste de madeira da sua lança era como o cilindro dos tecelões, e a lâmina da sua lança era de seiscentos siclos de ferro; e o carregador do escudo grande marchava na frente dele. ${ }^{8}$ Então ficou parado e começou a chamar as fileiras combatentes de Israel e a dizer-lhes: "Por que saís para vos pordes em formação de batalha? Não sou eu filisteu e vós servos pertencentes a Saul? Escolhei para vós um homem e desça ele a mim. ${ }^{9}$ Se ele puder lutar comigo e deveras me golpear, então teremos de ser vossos servos. Mas, se eu mesmo puder com ele e deveras o golpear, então vós tereis de tornar-vos servos nossos e tereis de servir-nos." ${ }^{10} \mathrm{E}$ o filisteu prosseguiu, dizendo: "Eu mesmo escarneço das fileiras combatentes de Israel no dia de hoje. Dai-me um homem e lutemos entre nós!"

${ }^{11}$ Quando Saul e todo o Israel ouviram estas palavras do filisteu, então ficaram aterrorizados e com muito medo.

${ }^{12}$ Ora, Davi era filho deste efratita de Belém de Judá, cujo nome era Jessé. E este tinha oito filhos. E nos dias de Saul, o homem já era velho entre os homens. ${ }^{13} \mathrm{E}$ os três filhos mais velhos de Jessé passaram a ir. Foram seguir Saul à guerra, e os nomes dos seus três filhos que foram à guerra eram 
Eliabe, o primogênito, e seu segundo filho, Abinadabe, e o terceiro, Samá.

${ }^{14}$ E Davi era o mais moço, e os três mais velhos é que foram seguir Saul.

${ }^{15}$ E Davi ia e então retornava de Saul para apascentar as ovelhas de seu pai em Belém. ${ }^{16} \mathrm{E}$ o filisteu avançava de manhã cedo e à noitinha, e tomava a sua posição por quarenta dias.

${ }^{17}$ Então Jessé disse a Davi, seu filho: "Por favor, leva a teus irmãos este efa de grãos torrados e estes dez pães, e carrega-os depressa ao acampamento, a teus irmãos. ${ }^{18} \mathrm{E}$ estas dez porções de leite deves levar ao chefe dos mil; também deves tomar nota do bem-estar de teus próprios irmãos e deves trazer deles algum sinal." ${ }^{19}$ No ínterim, tanto Saul como eles, e todos os outros homens de Israel estavam na baixada de Elá, lutando contra os filisteus.

${ }^{20}$ Concordemente, Davi levantou-se de manhã cedo e deixou as ovelhas com o guarda, e carregou-se e foi, assim como Jessé lhe ordenara. Quando chegou ao arraial, saíam as forças militares à linha de batalha e levantavam um grito de batalha. ${ }^{21} \mathrm{E}$ tanto Israel como os filisteus começaram a pôr em formação, fileira combatente para enfrentar fileira combatente. ${ }^{22}$ Davi deixou imediatamente a bagagem aos cuidados do guarda da bagagem e foi correndo até a linha de batalha. E ao chegar, começou a perguntar pelo bemestar de seus irmãos.

${ }^{23}$ Como falava com eles, ora, eis que subia o campeão, cujo nome era Golias, filisteu de Gate, das fileiras combatentes dos filisteus e começou a falar as mesmas palavras de antes, e Davi chegou a escutá-las. ${ }^{24}$ Quanto a todos os homens de Israel, vendo eles o homem, ora, fugiam por causa dele e tinham muito medo. ${ }^{25} \mathrm{E}$ os homens de Israel começaram a dizer: "Vistes este homem que está subindo? Pois é para escarnecer de Israel que ele está subindo. E tem de dar-se que, ao homem que o golpear, o rei enriquecerá com grandes riquezas e dar-lhe-á a sua própria filha, e libertará a casa de seu pai em Israel."

${ }^{26}$ E Davi começou a dizer aos homens parados perto dele: "Que se fará ao homem que golpear aquele filisteu lá e realmente tirar o vitupério de cima de Israel? Pois, quem é este filisteu incircunciso que venha escarnecer das fileiras combatentes do Deus vivente?" ${ }^{27}$ Então o povo disse-lhe as mesmas palavras de antes, dizendo: "Assim se fará ao homem que o golpear." ${ }^{28} \mathrm{E}$ Eliabe, seu irmão mais velho, estava ouvindo quando ele falou aos homens, e acendeu-se a ira de Eliabe contra Davi, de modo que disse: "Por que é que desceste? E com quem deixaste aquelas poucas ovelhas lá no ermo? Eu mesmo conheço muito bem a tua presunção e a ruindade do teu coração, pois desceste com o fim de ver a batalha." ${ }^{29}$ A isso Davi disse: "Que fiz agora? Não foi apenas uma palavra?" " ${ }^{30}$ Com isso voltou-se dele para outra pessoa e foi dizer as mesmas palavras como antes, e o povo, por sua vez, dava-lhe a mesma resposta de antes.

${ }^{31}$ Assim as palavras faladas por Davi começaram a ser ouvidas, e foram comunicá-las a Saul. Em vista disso, mandou trazê-lo. ${ }^{32}$ E Davi passou a dizer a Saul: "Não sucumba o coração de nenhum homem dentro dele. O próprio servo teu irá e realmente lutará com este filisteu." ${ }^{33}$ Saul, porém, disse a Davi: "Não podes ir contra este filisteu para lutar com ele, pois és apenas um rapaz e ele é homem de guerra desde a sua meninice." ${ }^{34}$ E Davi prosseguiu, dizendo a Saul: "Teu servo tornou-se pastor de seu pai entre o rebanho, e chegou um leão, e também um urso, e [cada um] levou embora 
um ovídeo da grei. ${ }^{35} \mathrm{E}$ eu saí atrás dele e o golpeei, e [o] livrei da sua boca. Quando começou a se levantar contra mim, agarrei-o pela sua barba e o golpeei, e o entreguei à morte. ${ }^{36}$ Tanto ao leão como ao urso teu servo golpeou; e este filisteu incircunciso terá de tornar-se como um deles, pois escarneceu das fileiras combatentes do Deus vivente." ${ }^{37}$ Davi acrescentou então: "Jeová, que me livrou da pata do leão e da pata do urso, ele é quem me livrará da mão deste filisteu." Então disse Saul a Davi: "Vai, e que o próprio Jeová mostre estar contigo."

${ }^{38}$ Então Saul foi vestir Davi com as suas vestes e pôs-lhe na cabeça um capacete de cobre, vestindo-o depois com uma cota de malha. ${ }^{39}$ Davi cingiuse então da sua espada sobre as suas vestes e pôs-se a ir, [mas não pôde,] porque não os tinha experimentado. Finalmente, Davi disse a Saul: "Não posso ir nestas coisas, pois não as experimentei." De modo que Davi as tirou de si. ${ }^{40}$ E ele passou a tomar seu bastão na mão e a escolher para si cinco das pedras mais lisas do vale da torrente e a pô-las na sua sacola de pastor, que lhe servia de receptáculo, e ele tinha sua funda na mão. E começou a aproximar-se do filisteu.

${ }^{41}$ E o filisteu começou a vir andando, chegando-se cada vez mais a Davi, e o homem que carregava o escudo grande estava na sua frente. ${ }^{42}$ Ora, quando o filisteu olhou e viu Davi, começou a desprezá-lo porque mostrava ser rapaz e ruivo, de bela aparência. ${ }^{43}$ Portanto, o filisteu disse a Davi: "Sou eu algum cão que vens a mim com bordões?" Com isso, o filisteu invocou o mal sobre Davi por meio dos seus deuses. ${ }^{44} \mathrm{E}$ o filisteu prosseguiu, dizendo a Davi: "Vem a mim, e eu hei de dar a tua carne às aves dos céus e aos animais do campo."

${ }^{45}$ Davi, por sua vez, disse ao filisteu: "Tu vens a mim com espada, e com lança, e com dardo, mas eu chego a ti com o nome de Jeová dos exércitos, o Deus das fileiras combatentes de Israel, de quem escarneceste. ${ }^{46}$ No dia de hoje Jeová te entregará na minha mão, e hei de golpear-te e tirar-te a cabeça de cima de ti; e neste dia hei de dar os cadáveres do acampamento dos filisteus às aves dos céus e aos animais selváticos da terra; e pessoas de toda a terra saberão que existe um Deus que pertence a Israel. ${ }^{47} \mathrm{E}$ toda esta congregação saberá que não é nem com espada nem com lança que Jeová salva, porque a Jeová pertence a batalha, e ele terá de entregar-vos na nossa mão."

${ }^{48}$ E sucedeu que o filisteu se levantou, e ele vinha e se chegava cada vez mais para enfrentar a Davi, e Davi começou a apressar-se e a correr para a linha de batalha, a fim de enfrentar o filisteu. ${ }^{49}$ Davi meteu então a mão na sua sacola, e tirou dali uma pedra e a atirou com a funda, atingindo assim o filisteu na sua testa e a pedra penetrou-lhe na testa, e ele foi cair com a sua face por terra. ${ }^{50}$ Portanto, Davi, com uma funda e uma pedra, mostrou ser mais forte do que o filisteu, e golpeou o filisteu e o entregou à morte; e não havia espada na mão de Davi. ${ }^{51}$ E Davi seguiu correndo e pôs-se de pé sobre o filisteu. Tomou então a espada dele e puxou-a da sua bainha, e entregou-o definitivamente à morte, decepando-lhe a cabeça com ela. E os filisteus estavam vendo que seu poderoso tinha morrido e puseram-se em fuga.

${ }^{52}$ Nisso se levantaram os homens de Israel e de Judá e irromperam em gritos, e foram no encalço dos filisteus até [o] vale e até os portões de Ecrom, e os mortalmente feridos dos filisteus caíam no caminho, desde Saaraim, tanto até Gate como até Ecrom. ${ }^{53}$ Os filhos de Israel retornaram 
depois de terem encarniçadamente perseguido os filisteus e foram rapinar os seus acampamentos.

${ }^{54}$ Davi tomou então a cabeça do filisteu e a levou a Jerusalém, e as armas dele pôs na sua tenda (1 Samuel 17: 1-54) (TRADUÇÃO do Novo Mundo das Escrituras Sagradas, 1992, p. 383-386).

O relato bíblico de 1 Samuel (17: 1-54) constitui-se como fonte primeira e fiadora do discurso instrucional considerado, ou seja, constitui-se como discurso fundador, graças ao caráter de autoridade apresentado pela palavra revelada.

A presença de sua referência por meio da indicação presente no final da história e nas perguntas complementares de estudo bíblico instituem o caráter de legitimação desse discurso e da história nele relatada de modo parafrástico.

O livro bíblico de Samuel, presente nas Escrituras Hebraico-Aramaicas, apresenta-se como um livro histórico de autoria do profeta Samuel. O gênero desse discurso o apresenta como uma narrativa histórica, cujo tema principal constitui-se por meio das relações de Israel com Jeová, em sua fidelidade ou infidelidade à palavra de Deus, representada pelos profetas tidos como seus porta-vozes.

A divisão de Samuel em dois livros distintos, que inicialmente constituíam um só rolo de volume, remonta à tradição da Septuaginta Grega. O primeiro livro de Samuel abrange as vidas dos quatro líderes de Israel: Eli, o sumo sacerdote; Samuel, o profeta; Saul, o primeiro rei; e Davi, que foi ungido para ser o próximo rei. O relato bíblico, considerado no enunciado instrucional (1 Samuel 17: 1- 54), abrange o relato original das atividades de Davi por meio de sua unção e do testemunho de sua bravura, oriunda de indignação e coragem inspirada ao derrotar o gigante Golias e livrar Israel da vergonha. 


\section{1 "Davi e Golias": Análise Semiótica}

Assim, voltemos à unidade recortada, "Davi e Golias", caracterizada por ser um texto narrativo pautado pela progressão temporal e reduplicação mítica do discurso fundador, no caso, o livro bíblico de Samuel (1 Samuel 17:1-54).

No que diz respeito ao estabelecimento de um percurso gerativo do sentido, ferramenta para a depreensão do sentido dos textos, podemos estabelecer a seguinte estrutura fundamental representada por meio do seguinte quadrado semiótico. A direção das setas apresenta a orientação seguida pelo enunciado considerado:

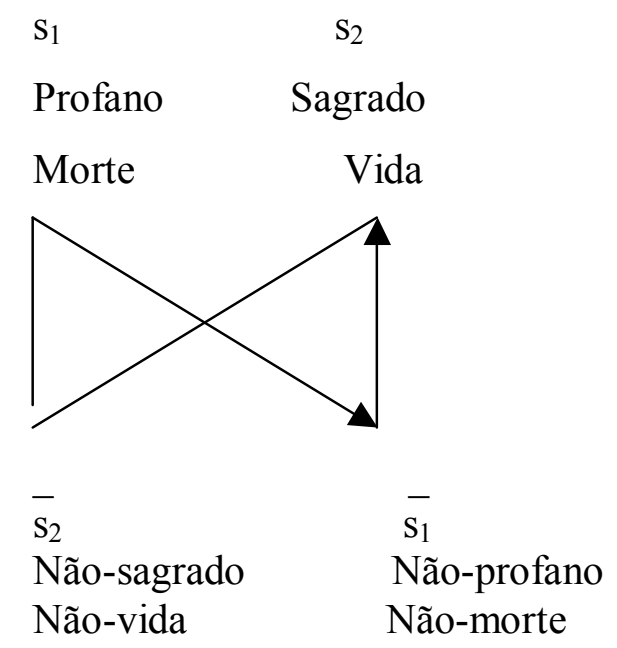

Ao realizar a análise de "Davi e Golias", vemos que a oposição fundamental é estabelecida no texto entre os termos contrários (profano e sagrado) e contraditórios (nãoprofano e não-sagrado), que se relacionam, por sua vez, às categorias de vida e morte.

O profano (humano) é representado pelo domínio da descrença aos ideais propostos e o sagrado (divino) ao domínio da prática institucionalizada por meio da esfera de circulação das Testemunhas de Jeová. Sendo o sagrado, representativo, portanto, da crença nas verdades presentes nas Sagradas Escrituras. 
Dessa forma, temos a seguinte axiologização dos termos do quadrado: os termos (sagrado e não-profano) são axiologizados com valores eufóricos e os termos (profano e nãosagrado) com valores disfóricos. Esse modo específico de axiologizar valores corresponde aos ideais e preceitos de uma determinada formação ideológica, no caso, os valores propugnados pela doutrina neocristã das Testemunhas de Jeová.

Propomos, então, descrever os mecanismos sintáticos e semânticos da unidade considerada para análise. Consideraremos as estruturas concernentes à gramática narrativa, ao se constituírem como um nível imediatamente superior às estruturas fundamentais, no que diz respeito ao percurso gerativo do sentido,

Com relação ao Programa Narrativo (PN) de base que rege este discurso, observamos que a transformação principal operacionalizada constitui-se por meio da ação de um sujeito sobre outro. Este último, ao adquirir o conhecimento que o conduza à vida eterna, representado por meio das verdades presentes nas Sagradas Escrituras, pode adquirir e manter-se em conjunção com o objeto valor "graça divina".

\section{PN de base}

$$
\begin{aligned}
& \mathrm{S}_{1} \rightarrow \mathrm{S}_{2} \cap \mathrm{O}_{\mathrm{v}} \\
& \mathrm{S}_{1}=\text { enunciador do livro instrucional } \\
& \mathrm{S}_{2}=\text { leitor-aprendiz } \\
& \mathrm{O}_{\mathrm{v}}=\text { graça divina }
\end{aligned}
$$

No que concerne à narratividade imanente a este discurso, vê-se que sua constituição é baseada na instalação das seguintes seqüências narrativas, tal como se segue: 


$$
\begin{gathered}
\mathbf{S N}_{\mathbf{1}}=\text { Do enunciado } \\
\mathrm{F} \rightarrow\left[\mathrm{S}_{1} \rightarrow \mathrm{S}_{2} \cap \mathrm{O}_{\mathrm{v}} \text { "graça divina" }\right]
\end{gathered}
$$

\section{PN de Davi}

\section{Manipulação}

Pressuposta

$\mathrm{D}_{1} \rightarrow \mathrm{D}_{2} \cap \mathrm{O}_{\mathrm{v}}$

$\mathrm{D}_{1}=$ Jeová

$\mathrm{D}_{2}=$ Davi

$\mathrm{O}_{\mathrm{v}}=$ "graça divina"

\section{Competência}

Pressuposta

PN de aquisição de competência

(Jeová escolhe Davi e o confere a unção com óleo legitimando a sua bravura e coragem.)

\section{Performance}

$$
\begin{aligned}
& \mathrm{S}_{1} \rightarrow\left(\mathrm{S}_{2} \cup \mathrm{O}_{\mathrm{v}}\right) \rightarrow\left(\mathrm{S}_{2} \cap \mathrm{O}_{\mathrm{v}}\right) \\
& \mathrm{S}_{1}=\text { Jeová } \\
& \mathrm{S}_{2}=\text { Davi } \\
& \mathrm{O}_{\mathrm{v}}=\text { dom divino (graça divina) }
\end{aligned}
$$

\section{Sanção}

Cognitiva $=$ Reconhecimento 
Pragmática $=$ Recepção da unção com óleo que legitima a bravura de Davi.

\section{$\mathbf{1}^{\mathrm{a}} . \mathrm{SN}$}

\section{Manipulação}

$\mathrm{D}_{1} \rightarrow \mathrm{D}_{2} \cap \mathrm{O}_{\mathrm{m}}$

$\mathrm{D}_{1}=$ Jeová

$\mathrm{D}_{2}=$ Davi

$\mathrm{O}_{\mathrm{m}}=$ querer ter poder (força) para derrotar o inimigo

\section{Competência}

PN de aquisição de competência

(Jeová confere a Davi a confiança no poder e força adquiridos)

\section{Performance}

$\mathrm{S}_{1} \rightarrow\left(\mathrm{S}_{2} \cup \mathrm{Ov}\right) \rightarrow\left(\mathrm{S}_{2} \cap \mathrm{O}_{\mathrm{v}}\right)$

$\mathrm{S}_{1}=$ Jeová

$\mathrm{S}_{2}=$ Davi

$\mathrm{O}_{\mathrm{v}}=$ querer manter a conjunção com o objeto valor "graça divina".

A Performance se realiza: Davi vence o inimigo.

\section{Sanção}

Cognitiva: Reconhecimento

Pragmática: Vitória (liberdade para o povo de Israel) 


\title{
PN do Anti-Sujeito:
}

\section{PN de Golias}

\section{$1^{\mathrm{a}} \cdot \mathrm{SN}$}

\author{
Manipulação \\ $\mathrm{D}_{1} \rightarrow \mathrm{D}_{2} \cap \mathrm{O}_{\mathrm{m}}$ \\ $\mathrm{D}_{1}=$ Golias \\ $\mathrm{D}_{2}=$ Golias \\ $\mathrm{O}_{\mathrm{m}}=$ querer ter os israelitas como seus escravos
}

\section{Competência}

Pressuposta

Poder

(caracteres que o constituem como soldado)

\section{Performance}

Realiza-se (Golias zomba dos israelitas).

\section{Sanção}

Reconhecimento da possibilidade de sua vitória. 


\section{Manipulação}

Pressuposta

$\mathrm{D}_{1} \rightarrow \mathrm{D}_{2} \cap \mathrm{O}_{\mathrm{m}}$

$\mathrm{D}_{1}=$ Falsos deuses

$\mathrm{D}_{2}=$ Golias

$\mathrm{O}_{\mathrm{m}}=$ querer ter o poder (força)

\section{Competência}

Pressuposta

PN de aquisição de competência

(Ele já possuiria os caracteres que o confirmariam como soldado)

\section{Performance}

$\mathrm{S}_{1} \rightarrow\left(\mathrm{S}_{2} \cup \mathrm{O}_{\mathrm{v}}\right) \rightarrow\left(\mathrm{S}_{2} \cap \mathrm{O}_{\mathrm{v}}\right)$

$\mathrm{S}_{1}=$ Falsos deuses

$\mathrm{S}_{2}=$ Golias

$\mathrm{O}_{\mathrm{v}}=$ força/ poder vencer o inimigo

A Performance não se realiza: Golias é derrotado

\section{Sanção}

Cognitiva $=$ Derrota

Pragmática $=$ morte 


\section{$\underline{\text { PN do Rei Saul }}$}

PN Prévio

$$
\mathrm{F} \rightarrow\left[\mathrm{S}_{1} \rightarrow \mathrm{S}_{2} \cap \mathrm{O}_{\mathrm{m}}\right]
$$

$\mathrm{F}=$ Convencer os soldados de que eles poderiam matar o filisteu Golias e livrar Israel da vergonha.

$$
\begin{aligned}
& \mathrm{S}_{1}=\text { Rei Saul } \\
& \mathrm{S}_{2}=\text { soldados } \\
& \mathrm{O}_{\mathrm{m}}=\text { poder vencer o inimigo. }
\end{aligned}
$$

\section{Manipulação}

Pressuposta

$\mathrm{D}_{1} \rightarrow \mathrm{D}_{2} \cap \mathrm{O}_{\mathrm{m}}$

$\mathrm{D}_{1}=$ Rei Saul

$\mathrm{D}_{2}=$ soldados

$\mathrm{O}_{\mathrm{m}}=$ Poder vencer o inimigo

\section{Competência}

Pressuposta

Poder (Habilidades que os constituem como soldados).

\section{Performance}

$\mathrm{S}_{1} \rightarrow\left(\mathrm{S}_{2} \cup \mathrm{Ov}\right) \rightarrow\left(\mathrm{S}_{2} \cap \rightarrow \mathrm{O}_{\mathrm{v}}\right)$

$\mathrm{S}_{1}=$ Rei Saul 


$$
\begin{aligned}
& \mathrm{S}_{2}=\text { soldado } \\
& \mathrm{O}_{\mathrm{v}}=\text { querer ter a conjunção com o objeto valor riquezas e filha do Rei Saul dada em }
\end{aligned}
$$
casamento.

A Performance não se realiza: Os Israelitas se amedrontam diante de Golias.

\section{Sanção}

Pragmática: A conjunção com os objetos de valor descritivo propostos pelo Rei Saul não se realiza.

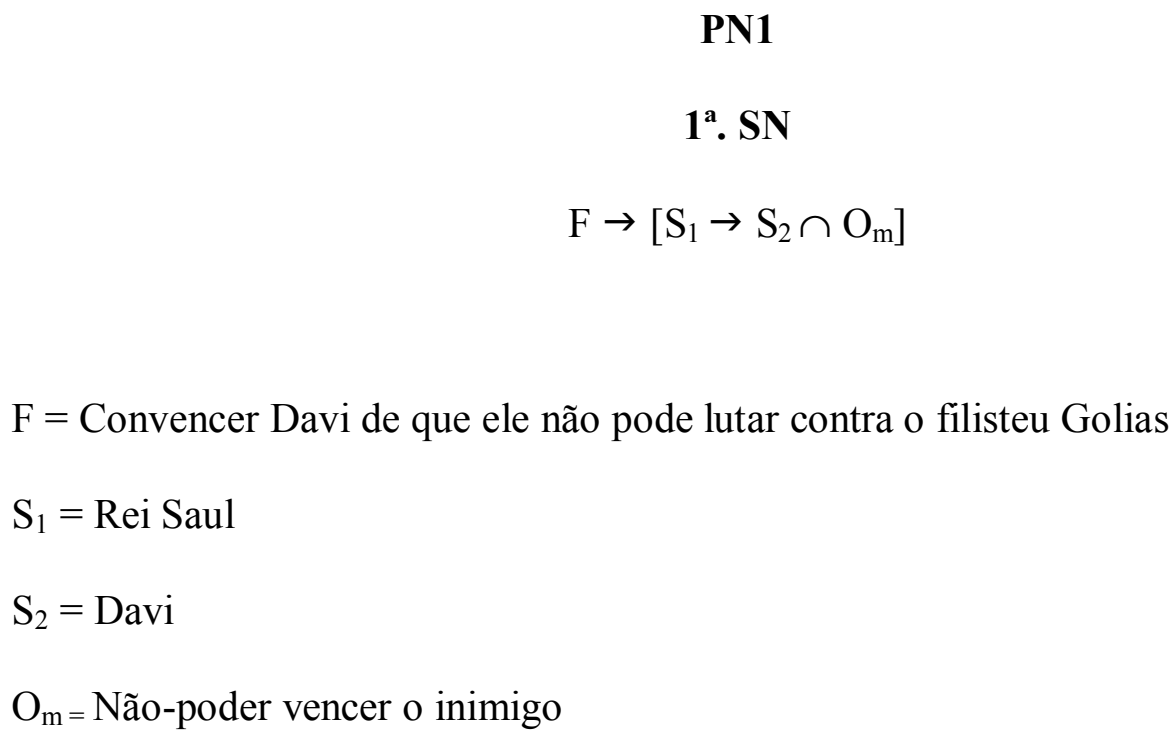

\section{Manipulação}

$\mathrm{D}_{1} \rightarrow \mathrm{D}_{2} \cap \mathrm{O}_{\mathrm{m}}$

$\mathrm{D}_{1}=$ Rei Saul

$\mathrm{D}_{2}=$ Davi

$\mathrm{O}_{\mathrm{m}}=$ Não-poder vencer o inimigo

\section{Competência}

Não-poder 
(Fraca estatura física, inabilidade como soldado)

\section{Performance}

A Performance do Rei Saul não se realiza. Davi luta contra o Filisteu e vence a batalha.

\section{Sanção}

Cognitiva: Reconhecimento

Pragmática: Davi recebe a filha do Rei Saul em casamento.

\section{SN2 = enunciação como construção do enunciado}

$\mathrm{F} \rightarrow\left[\mathrm{S}_{1} \rightarrow\left(\mathrm{S}_{2} \cap \mathrm{O}_{\mathrm{v}}\right.\right.$ enunciado $\left.)\right]$

$\mathrm{S}_{1}=$ Testemunhas de Jeová como instituição religiosa

$\mathrm{S}_{2}=$ Sujeito enunciador - comentador

\section{Manipulação}

$\mathrm{E}_{1} \rightarrow \mathrm{E}_{2} \cap \mathrm{O}_{\mathrm{m}}$

$\mathrm{E}_{1}=$ Instituição religiosa das Testemunhas de Jeová / Valores ideológicos.

$\mathrm{E}_{2}=$ enunciador

$\mathrm{O}_{\mathrm{m}}=$ dever assimilar e doutrinar por meio dos livros instrucionais nos princípios da fé, moral e práticas das Testemunhas de Jeová. (Escrever Meu Livro de Histórias Bíblicas). 


\section{Competência}

$\mathrm{S}_{2} \quad$ Sabe

Escrever o livro instrucional Meu Livro de Histórias Bíblicas

Pode

\section{Performance}

$\mathrm{S}_{2}$ constrói o $\mathrm{O}_{\mathrm{v}}$ enunciado

\section{Sanção}

$\mathrm{S}_{2}$ é reconhecido.

\section{$\mathrm{SN}_{3}=$ Programa narrativo de base (construção de significado pelo enunciatário por intermédio da enunciação)}

$$
\mathrm{F} \rightarrow\left[\mathrm{S}_{1} \rightarrow\left(\mathrm{S}_{2} \cap \mathrm{O}_{\mathrm{v}} \text { graça divina }\right)\right]
$$

$\mathrm{F}=$ fazer-saber (saber sobre o ser dos valores/ saber sobre o fazer)

Apresentar as verdades presentes nas Sagradas Escrituras como transmissão de um modelo de conduta exemplar

$$
\begin{aligned}
& \mathrm{S}_{1}=\text { enunciador do livro instrucional (comentador) } \\
& \mathrm{S}_{2}=\text { leitor-aprendiz } \\
& \mathrm{O}_{\mathrm{v}}=\text { graça divina (aceitação dos princípios da fé, moral e prática das Testemunhas de }
\end{aligned}
$$
Jeová) 
Em Meu livro de Histórias Bíblicas, os acontecimentos bíblicos ao serem narrados em sua progressão pressupõem relações de anterioridade e posterioridade entre as lições consideradas.

Observamos que o PN de base que rege este enunciado, apresenta o Sujeito $\mathrm{S}_{1}$ fazendo com que $\mathrm{S}_{2}$ permaneça em conjunção com o Ov "graça divina", cujo investimento semântico e atribuição já teriam sido efetuados num PN prévio subentendido. Esse PN prévio remonta à História Bíblica 57 "Deus escolhe Davi", imediatamente anterior à História 58 "Davi e Golias" considerada para análise.

Por meio desse PN prévio, já se teria atribuído ao actante sujeito Davi o $\mathrm{O}_{\mathrm{v}}$ "graça divina", por meio da recepção do dom divino, representado por meio da unção com óleo que legitimaria a bravura de Davi.

Assim, por meio desse PN prévio, Davi já teria sido, cognitiva e pragmaticamente, premiado por meio da recepção do dom da coragem divinamente inspirada. Cabe ao PN de base, portanto, a atribuição da confiança no poder e força adquiridos para que o sujeito continue em conjunção com o $\mathrm{O}_{\mathrm{v}}$ alcançado e possa derrotar Golias.

Inicialmente, ao observarmos a narratividade imanente à primeira seqüência narrativa $\left(\mathrm{SN}_{1}\right)$ (do enunciado), da qual seu esquema se encontra presente nas páginas anteriores, observa-se, por meio do conto exemplar, a narrativa de transformação de estados do sujeito Davi, que inicialmente disjunto do poder e força para derrotar seu inimigo "Golias" (o filisteu de Gate), busca a sua conjunção. Essa conjunção com o objeto de valor modal, representado pelo querer ter poder e força, dá-se por meio do programa narrativo de doação de competência. Nesse programa narrativo, Jeová confere a confiança no poder e força que seriam necessários a Davi. Davi é modalizado pelo: querer, dever, poder e saber-ser conjunto com os valores propostos. Com isso, a performance se realiza, Davi como um sujeito 
confiante em sua força e poder divinamente inspirados executa Golias, seu inimigo, fazendo com que os israelitas vençam a batalha.

Assim, observamos que a narratividade imanente a esta seqüência narrativa $\left(\mathrm{SN}_{1}\right)$, do enunciado, apresenta seu desenvolvimento em torno da paixão da expectativa, que de acordo com Greimas (1983, p. 229), pode ser formulada como se segue:

$$
\begin{aligned}
& \mathrm{S}_{1} \text { querer }\left[\mathrm{S}_{2} \rightarrow\left(\mathrm{S}_{1} \cap \mathrm{O}_{\mathrm{v}}\right)\right] \\
& \text { Onde } \\
& \mathrm{S}_{1} \text { é o sujeito de estado e } \\
& \mathrm{S}_{2} \text { é o sujeito do fazer }
\end{aligned}
$$

A paixão da expectativa pode se desenvolver por meio da espera simples, "que põe o sujeito em relação com um objeto de valor" $\left(\mathrm{S} \rightarrow \mathrm{O}_{\mathrm{v}}\right)$, ou por meio de uma expectativa fiduciária, que supõe "relações modais", intersubjetivas $\left(\mathrm{S}_{1} \rightarrow \mathrm{S}_{2}\right)$, "com um outro sujeito" (GREIMAS, 1983, p. 227).

A narrativa de "Davi e Golias" se desenvolve em torno da expectativa fiduciária, uma espera baseada na confiança. A expectativa fiduciária, dado o caráter intersubjetivo proposto, põe o sujeito em relação a outros sujeitos $\left(\mathrm{S}_{1} \rightarrow \mathrm{S}_{2}\right)$. No enunciado considerado, a expectativa fiduciária pressupõe uma relação intersubjetiva entre Davi e Jeová. Essa expectativa fiduciária de Davi em relação a Jeová vai transformar Davi de um sujeito atualizado, ou seja, dotado de um querer estar conjunto com o objeto de valor almejado, em um sujeito realizado, ou seja, conjunto com o objeto de valor.

Desse modo, temos o sujeito de estado, Davi, desejoso de que a conjunção com o objeto valor "graça divina" seja realizada pelo sujeito do fazer (Jeová).

O desenvolvimento da paixão da expectativa fiduciária no enunciado considerado, dado o caráter intersubjetivo proposto, desenvolve-se por meio de uma expectativa fiduciária mútua e recíproca entre os atores do enunciado "Davi” e "Jeová". Davi quer que Jeová o 
coloque em conjunção com o objeto valor "graça divina", da mesma maneira que Jeová também é desejoso de que Davi mantenha essa conjunção. Se Davi espera que Jeová o sustente na graça, Jeová espera que Davi seja responsivo à altura:

$\mathrm{S}_{1}$ querer $\left[\mathrm{S}_{2} \rightarrow\left(\mathrm{S}_{1} \cap \mathrm{O}_{\mathrm{v}}\right)\right]$

Em que:

$\mathrm{S}_{1}$ é o sujeito de estado (Davi)

$\mathrm{S}_{2}$ é o sujeito do fazer (Jeová)

$\mathrm{Ou}$

$\mathrm{S}_{1}$ é o sujeito de estado (Jeová)

$\mathrm{S}_{2}$ é o sujeito de fazer (Davi)

Davi poderia ter entrado na paixão da dúvida, ao pressupor incapacidade de realização de sua vitória, dada sua fragilidade de caracteres físicos e inabilidade como soldado, tal como o Rei Saul tentou persuadi-lo. Entretanto, Davi sabia de sua capacidade. Capacidade essa, proveniente de uma espera fiduciária mútua e recíproca: uma espera baseada na confiança divinamente inspirada.

Desse modo, podemos retomar os seguintes versículos na medida em que reproduzem a mesma formação ideológica do corpus em análise:

Para todas as coisas tenho força em virtude daquele que me confere poder. Filipenses $4: 13 *^{* 11}$

“Tu és minha esperança, ó Soberano Senhor Jeová, minha confiança desde a minha mocidade". - Salmo 71:5.

Verificamos que esses versículos reproduzem a mesma formação ideológica que o enunciado de "Davi e Golias". Ambos pertencem a uma formação ideológica que ressalta o contrato imaginário, uma confiança mais do que um desejo. É uma formação discursiva que

${ }^{11}$ As referências bíblicas utilizadas ao longo das análises do corpus das Testemunhas de Jeová referem-se à Tradução do Novo Mundo das Escrituras Sagradas, e a menos que hajam outras indicações nos enunciados de divulgação, esta tradução se constitui como seu texto de referência principal. 
exalta a construção do simulacro intersubjetivo entre o fiel e Deus (Jeová). Portanto, uma formação discursiva altamente motivada, dado que repousa na experiência da interação.

Dessa maneira, o poder e autoridade conferidos pela ideologia neocristã ${ }^{12}$ das Testemunhas de Jeová a esse enunciador do livro instrucional (comentador), faz com que o enunciador proceda a construção do livro instrucional, dirigido ao público infanto-juvenil.

O destinador-manipulador, graças ao poder que lhe foi conferido, busca estabelecer um contrato fiduciário com o destinatário-sujeito por meio da crença na palavra revelada pela divindade (Jeová), obtida e conservada pelas Sagradas Escrituras, por meio da religião das Testemunhas de Jeová.

Para procedermos à definição do discurso de divulgação considerado, tomamos como base os desenvolvimentos de Panier (1986) ao longo de sua proposição de uma tipologia dos discursos de comentário. Panier (1986), ao tomar como base a função da narrativa de comentário, no que concerne ao seu fazer persuasivo como comunicação do saber, estabelece uma tipologia dos discursos de comentário segundo a posição formal desse desempenho de comunicação no modelo narrativo canônico.

Desse modo, podemos definir o enunciado considerado sob a tipologia de um comentário prescritivo. Vejamos como Panier (1986) procede à descrição desse tipo de comentário:

De início, o comentário pode recobrir a comunicação de um querer-fazer ou de um dever-fazer ao narratário. $O$ saber transmitido a este último corresponde, seja ao saber sobre o ser dos valores, e pode, então, determinar um programa narrativo para o narratário, seja ao saber sobre o fazer, se se trata, para o narratário, de reproduzir os desempenhos da narrativa comentada, que se torna, nesse caso, uma espécie de "modelo". Chamaremos de prescritivo esse tipo de comentário (PANIER, 1986, p. 269).

\footnotetext{
${ }^{12}$ A designação dessa esfera de circulação religiosa como Neocristã advém do estudo feito por JACOB, César Romero et al. no Atlas da Filiação Religiosa e Indicadores Sociais no Brasil. São Paulo: Loyola, 2003; na tentativa de estabelecer uma tipologia das religiões existentes no território brasileiro.
} 
Assim, observamos que a modalização deôntica estabelece a instauração de um programa de ação neste discurso, por meio do percurso de um querer-fazer e saber sobre o ser dos valores e de um saber sobre o fazer, instaurado pelo destinador ao operar com a revelação dos saberes míticos presentes nas Sagradas Escrituras. O destinador-manipulador busca a adesão do destinatário-sujeito por meio da manipulação executada na ordem do querer e saber fazer, ao apresentar a exemplaridade do percurso desenvolvido pelo sujeito Davi.

Assim, este discurso estabelece um lugar de mediação entre Jeová e o fiel, por meio da apresentação de uma narrativa mítica exemplar. Essa mediação visa construir uma manipulação, para que o leitor-aprendiz (actante coletivo), tendo sido persuadido, tendo aderido ao objeto do saber (a revelação do relato bíblico da batalha de "Davi e Golias") e, portanto, deonticamente modalizado, queira aprender os fundamentos bíblicos em conformidade com os valores da ideologia neocristã das Testemunhas de Jeová. Dessa forma, o leitor-aprendiz, ao aderir à performance de crença e glorificação de tais verdades, é sancionado positivamente com a salvação.

Com relação ao exame das estruturas discursivas do referido texto, observamos que este se caracteriza pela utilização de uma debreagem enunciva do enunciado. As estratégias do enunciador constituem-se na ocultação do eu-aqui-agora, ancorando os movimentos do sentido dos atores do enunciado, num tempo figurativizado como o tempo do então e num espaço topicalizado como o espaço do alhures. Tem-se, assim, a emergência dos atores do enunciado, por meio de um enunciado que parece se enunciar sozinho.

A história bíblica considerada, ao ser apoiada no texto figurativo, é pautada pela construção da aura do encantado e do maravilhoso.

Desse modo, realizaremos a seguir o exame da sintaxe discursiva do referido enunciado instrucional. Estudaremos as marcas da enunciação no enunciado por meio dos 
procedimentos de actorialização, temporalização e espacialização, referentes à instauração de pessoas, tempo e espaço no discurso.

No que diz respeito aos procedimentos de actorialização presentes no enunciado instrucional considerado, notamos a presença de um narrador explícito que dá voz aos actantes do enunciado, instalando-os no discurso por meio de uma debreagem interna enunciativa de segundo grau. Essa debreagem dá-se pela presença do discurso direto instalado entre aspas, que instaura o diálogo entre os actantes representados por Davi e Golias.

Vejamos como Fiorin (2002, p. 72-74) procede á caracterização do discurso direto empreendido no enunciado considerado:

O discurso direto é resultado de uma debreagem interna (em geral de segundo grau), em que o narrador delega voz a um actante do enunciado. Possui duas instâncias enunciativas, dois níveis de eu: o do narrador e o do interlocutor. O discurso direto é um simulacro da enunciação construído por intermédio do discurso do narrador. [...] O discurso direto, em geral, cria um efeito de sentido de realidade, pois dá a impressão de que o narrador está apenas repetindo o que disse o interlocutor.

Consideremos o seguinte trecho do enunciado instrucional:

Mas, Davi disse: "Você vem a mim com espada, lança e dardo, mas eu o enfrento no nome de Jeová. Hoje, Jeová entregará você na minha mão e eu o abaterei" (MEU LIVRO de Histórias Bíblicas, 1978, História 58).

Para fazer emergir os actantes do enunciado, ao introduzir o discurso direto, o narrador se enuncia por meio de um verbum dicendi (de dizer): "Mas, Davi disse (...)" (grifo nosso).

O discurso reportado deve ser marcado, para que o enunciatário perceba a distinção entre discurso citante e citado. As marcas são diferentes no texto oral ou escrito. A marca mais importante, sem dúvida, é o verbo introdutor, em geral um verbum dicendi (FIORIN, 2002, p.77). 
Desse modo, o discurso direto é resultante da debreagem interna enunciativa de segundo grau, por meio da qual o narrador delega voz aos actantes do enunciado e projeta duas instâncias enunciativas autônomas concernentes à presença de dois atos enunciativos, duas vozes: a do narrador e a do personagem (interlocutor). Assim, por meio do emprego do discurso direto, recria-se a situação da enunciação por intermédio do narrador.

Com relação à temporalização, notamos na fala do narrador a presença do tempo enuncivo no subsistema da anterioridade ao marco referencial pretérito (concomitância 2), marcado por verbos no pretérito imperfeito, e que denotam a idéia de inacabado, de uma ação ainda em seu transcurso.

O imperfeito [...] apresenta os fatos como simultâneos, como formando um quadro contínuo, ou melhor, como vinculados ao mesmo momento de referência pretérito. Por isso, é o tempo que melhor atende aos propósitos da descrição (FIORIN, 2002, p. 158).

Mas, todos os israelitas estavam com medo de Golias, porque era muito grande. Tinha uns três metros de altura, e tinha um outro soldado para carregar-lhe o escudo (MEU LIVRO de Histórias Bíblicas, 1978, História 58.). (grifo nosso)

Também verificamos a presença de verbos no pretérito perfeito 2 que indicam a pontualidade e término das ações executadas, tal como:

Tirou uma pedra da bolsa, colocou-a na funda e atirou-a com toda a força. A pedra atingiu Golias bem na cabeça, e ele caiu morto (MEU LIVRO de Histórias Bíblicas, 1978, História 58). (grifo nosso)

No que diz respeito à subversão temporal, estabelecida por meio do recurso das embreagens temporais e como efeito de neutralização das oposições temporais entre enunciado e enunciação, simulacro de realidade e objetividade, observa-se a instauração da concomitância 1 pela concomitância 2 (presente pelo pretérito perfeito 2). Assim, os verbos são dispostos no presente para expressarem concomitância ao marco referencial pretérito 
projetado no enunciado, para que se obtenha o efeito de sentido de objetividade e proximidade entre os tempos da enunciação e do enunciado. Esses mecanismos de subversão temporal encontram-se presentes, sobretudo, na segunda instância enunciativa representada pela voz dos personagens (interlocutores) dispostas no enunciado em discurso direto.

"Venha para cá", disse Golias, "e eu vou dar seu cadáver às aves e aos animais". Mas, Davi disse: "Você vem a mim com espada, lança e dardo, mas eu o enfrento no nome de Jeová. Hoje, Jeová entregará você na minha mão e eu o abaterei" (grifo nosso) (MEU LIVRO de histórias bíblicas, 1978, História 58).

A noção de espacialidade, ao corresponder ao que Lins (1976, p. 77) apud FIORIN (2002, p. 259), denomina ambientação, pode ser entendida "como o conjunto de processos conhecidos ou possíveis, destinados a provocar na narrativa a noção de um determinado ambiente".

A ambientação, correspondente aos espaços nos quais se movimentam os personagens, encontra-se organizada no enunciado instrucional considerado em função de um ponto instalado no interior do texto: o acampamento do exército em que se dera o embate entre Davi e Golias.

A espacialização da referente narrativa, ao remeter à reduplicação mítica do discurso fundador, realizada de modo parafrástico, reconstrói a cena da enunciação por meio do uso de uma debreagem enunciva por meio da figurativização desse espaço instaurado no interior da história bíblica.

A partir desse ponto instalado no interior do texto (linha de batalha do acampamento do exército), há uma movimentação dos personagens nesse espaço, por meio da modificação de suas posições dentro dessa categoria espacial, com o movimento de aproximação empreendido por Davi ao se dirigir a Golias para enfrentá-lo. 
O texto instrucional considerado apresenta em sua configuração temática a busca pelo conteúdo da fé e defesa divina dada por meio do seguinte investimento temático: a) tema da confiança em Jeová; b) tema da fé no apoio divino; c) tema da coragem divinamente inspirada; d) tema da disputa entre competidores desiguais; e) tema da competição (batalha) entre os deuses falsos e o verdadeiro Deus, Jeová; f) tema do heroísmo mítico; g) tema da força e poder divinos em contraposição à força e poder não provenientes de Jeová.

Em função do seu revestimento figurativo, o texto apresenta a emergência dos personagens Davi e Golias, cuja narração de suas ações empreendem situações concretas de transformação e mudanças de estado. As figuras de Davi e do gigante remetem à configuração discursiva que apresenta como núcleo temático a vulnerabilidade da natureza humana transformada em poder e força, se lhe for instituída a graça divina.

Desse modo, o texto apresenta seu revestimento figurativo pertencente à isotopia bélica, pautada pela situação figurativa narrada. Concretizam essa isotopia as seguintes figuras: acampamento do exército, linha de batalha, soldados, batalha; e também as armas e armaduras características do período: escudo, lança, espada, dardo, pedra e funda.

Observamos que o texto instrucional de divulgação religiosa, da totalidade discursiva das Testemunhas de Jeová, apresenta-se como um texto figurativo, ao operar com a utilização de narrativas exemplares. A narração constitui-se como um texto figurativo, na medida em que: "trata de personagens concretizados semanticamente que atuam num tempo e espaço específicos" (CARVALHO, 2005, p. 43). 


\subsection{Manifestação: A cenografia considerada como uma unidade sincrética}

Assim, como observado com relação ao enunciado instrucional da totalidade discursiva católica, já analisada anteriormente, a história bíblica 58 “Davi e Golias” presente em Meu Livro de Histórias Bíblicas, da totalidade das Testemunhas de Jeová, apresenta a utilização de uma imagem visual da história bíblica na qual a lição é baseada (1 Samuel 17: 154).

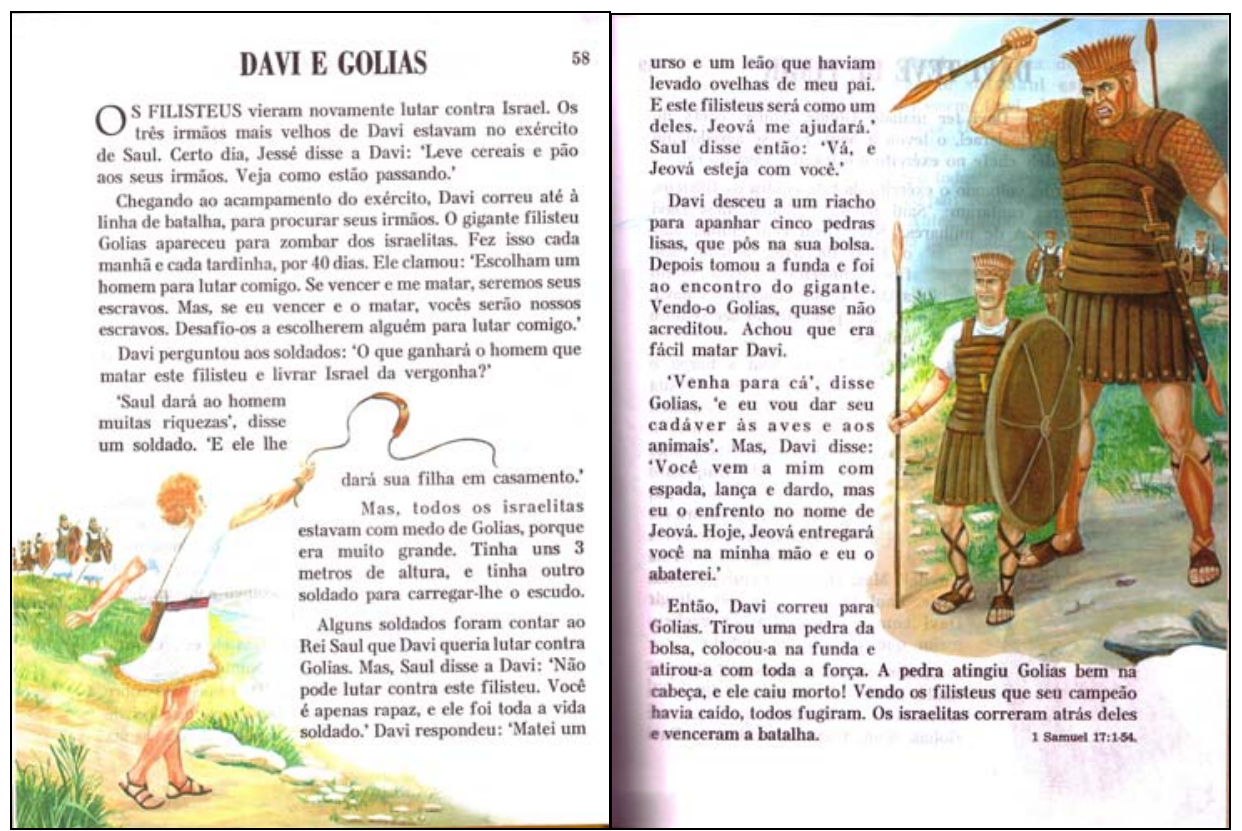

Ilustração 16 MEU LIVRO de Histórias Bíblicas. São Paulo: Sociedade Torre de Vigia de Bíblias e Tratados, 1978.

Ao tomar a terminologia proposta por Barthes (1984), no que concerne às relações estabelecidas entre o enunciado verbal e visual, que compõem a unidade sincrética, observamos a presença de um sincretismo entre imagem e palavra com função de etapa. A estratégia enunciativa, que sincretiza as diferentes linguagens de manifestação numa totalidade de sentido, exerce-se de modo contratual. 
A utilização desse gênero de pintura nos enunciados instrucionais considerados apresenta função essencialmente pedagógica, como meio de facilitação e visualização da mensagem presente nos textos sagrados. Seu objetivo principal, como convém aos discursos de divulgação religiosa, é divulgar o texto bíblico, tornando-o mais palatável ao enunciatário.

No que diz respeito à ilustração da História Bíblica 58 "Davi e Golias", presente nas extremidades do enunciado verbal, observamos a figurativização da cena da batalha empreendida entre Davi e Golias na linha de batalha do acampamento do exército, tal como relatada nas Sagradas Escrituras:

$17 \mathrm{E}$ os filisteus foram reunir seus acampamentos para a guerra. Quando se haviam reunido em Socó, que pertence a Judá, então passaram a acampar-se entre Socó e Azeca, em Efes-Damim. ${ }^{2}$ Quanto a Saul e aos homens de Israel, reuniram-se e passaram a acampar-se na baixada de Elá, e foram pôrse em formação de batalha para enfrentar os filisteus. ${ }^{3} \mathrm{E}$ os filisteus estavam parados no monte deste lado e os israelitas estavam parados no monte daquele lado, com o vale entre eles (1 Samuel 17: 1-3).

A transposição do texto verbal para o enunciado visual, graças aos recursos da gestualidade e expressão das figuras no enunciado plástico, exacerbam as paixões do enunciatário, na medida em que a imagem, devido aos recursos visuais apresentados, apresenta uma estratégia argumentativa de manipulação mais envolvente que a palavra escrita. A imagem apresentada pela concretização dos personagens e a imagem da cena de batalha são dadas de modo hiperbólico. Assim, o sujeito (Davi) e o anti-sujeito (Golias) estão visualmente modalizados pela paixão no que diz respeito às suas expressões faciais e corporais, o que demonstra a vantagem do enunciado plástico ao se considerar as modalizações do enunciador na divulgação do enunciado bíblico como uma narrativa exemplar. Verificamos também a frontalidade dos perfis dos personagens de Davi e Golias, pautados pela perspectiva enunciva dos olhares. O texto instrucional considerado apresenta em sua configuração temática o tema da disputa entre competidores desiguais, tema este 
frequentemente desenvolvido na literatura por um revestimento figurativo diverso. Tal tema demonstra que a habilidade para a realização de uma tarefa não estaria vinculada exclusivamente ao poder e à capacidade física. Desenvolve-se, portanto, no enunciado plástico, a isotopia do heróísmo mítico do sujeito Davi, conjunto com a força e poder divinamente inspirados.

Com relação ao nível narrativo, tem-se instaurado no enunciado o PN de Davi por meio da realização de sua performance contra seu inimigo. Davi, como um sujeito confiante e competente em sua força e poder, divinamente inspirados, desafia Golias, seu inimigo.

Davi e os soldados de Israel aparecem figurativizados em formação de batalha, dispostos num monte mais baixo do que o ocupado pelos filisteus, separados pela presença de um vale entre eles. Esse vale estaria representado no livro instrucional por meio de uma lacuna na imagem, tendo seu preenchimento dado por meio do enunciado verbal na história considerada.

Assim, ao observarmos a imagem, vemos que ela se divide dicotomicamente por meio da articulação de duas unidades discretas, esquerda vs. direita, separadas pela presença de uma linha diagonal. 


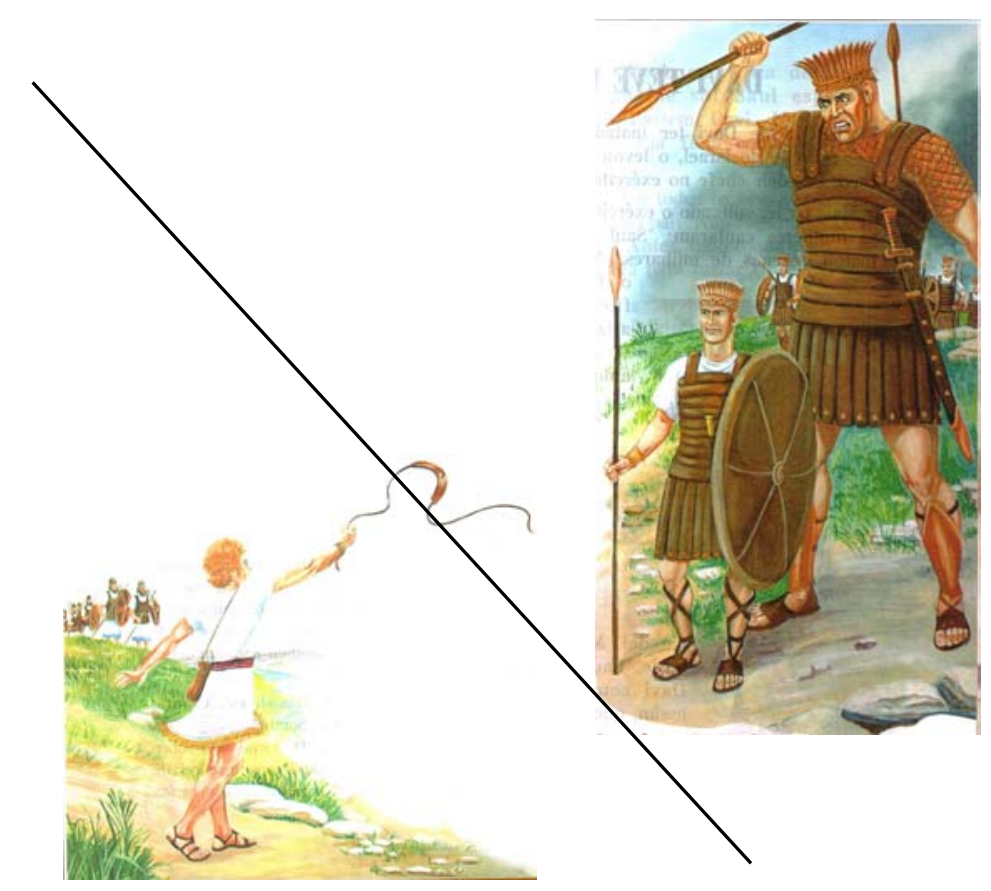

Ilustração 17 MEU LIVRO de Histórias Bíblicas. São Paulo: Sociedade Torre de Vigia de Bíblias e Tratados, 1978.

O percurso da beligerância figurativizada por Golias, correspondente dentro dessa ideologia à crença em falsos deuses, se opõe ao percurso da coragem divinamente inspirada, representada por Davi. Também observamos dentro desse pólo dicotômico a claridade e simplicidade das vestes de Davi, somadas ao seu semblante sereno, confiante do poder (graça divina) atribuído por Jeová, ao que se opõe a riqueza ornamental e o semblante beligerante de Golias.

Observaremos, a seguir, a materialização da categoria plástica, em correspondência às categorias cromáticas, eidéticas e topológicas. No que diz respeito ao cromatismo, verificamos a presença de uma multiplicidade cromática, dada por meio da oposição entre as categorias plásticas: monocromático vs. colorido, na medida em que estas representam, respectivamente, o percurso do herói mítico Davi e o percurso da beligerância do anti-sujeito Golias. 
Quanto à forma, descrita mediante a categoria eidética: homogêneo vs. heterogêneo, podemos relacionar a homogeneidade à representação do sujeito Davi e a heterogeneidade ao anti-sujeito Golias.

A apreensão da totalidade da imagem da figurativização da cena da batalha dá-se mediante a categoria multiplicidade, por oposição à unidade do plano de fundo.

No que diz respeito à categoria plástica topológica, temos a articulação entre as categorias esquerda/ inferior para o sujeito Davi e direita/ superior ao anti-sujeito Golias.

Para que possamos delinear uma tentativa de explicitação do estilo que permeia a imagem considerada, tomamos como base os desenvolvimentos de Wölflin (2000).

No que concerne ao traço, observamos a presença de uma composição dada por meio de manchas. A desvalorização das linhas e contornos, privilegiando uma visão globalizada do conjunto, permite associar essa imagem ao estilo pictórico. A atenção deixa de se concentrar nas margens e limites, na medida em que a articulação entre as imagens, dispostas entre o elemento verbal sem a delimitação de uma moldura definida, faz com que o olhar percorra os objetos representados como manchas.

Os contornos não acentuados favorecem a ligação entre as figuras, denotando a impressão de um movimento contínuo dado na cena de batalha. Quanto à disposição das imagens, observamos a presença de uma disposição dada em profundidade. As figuras estão dispostas em diagonal, sugerindo, por meio da visão em profundidade, a percepção de um movimento contínuo.

O tipo de contorno gerado pelo traço apresenta a categoria aberto, na medida em que o conteúdo extrapola os limites do quadro, com a ausência de delimitação dada pela moldura. Buscando a representação do fortuito, concretiza a mobilidade do instante passageiro da ação representada. Ao abranger um espaço de tempo curto, pautado pela mobilidade e 
instantaneidade da performance realizada, a imagem se concentra, unicamente, na reprodução do breve instante em que se representa o ponto culminante da ação.

Ao contrário da claridade própria ao estilo linear, observamos a presença da uma obscuridade pictórica, na medida em que a forma é apresentada como algo mutável, que se transforma continuamente pela celeridade das ações representadas. A mobilidade e velocidade dos gestos, que chamam a atenção para os desenvolvimentos narrativos realizados, remonta a uma perspectiva acelerada que remete à estética pictórica, pautada pela inquietude.

Ao tomar como base as relações semi-simbólicas presentes no enunciado instrucional, consideraremos, inicialmente, as categorias topológicas responsáveis pela orientação das formas e figuras no espaço. A disposição das figuras na ilustração didática, que acompanha a História Bíblica de Davi e Golias, permite com que possamos estabelecer a seguinte categoria topológica: esquerda vs. direita e inferior vs. superior. De tal modo que possamos estabelecer a seguinte relação semi-simbólica: 

PC vida/sagrado
PC morte/profano
PE esquerda/inferior
PE direita/ superior

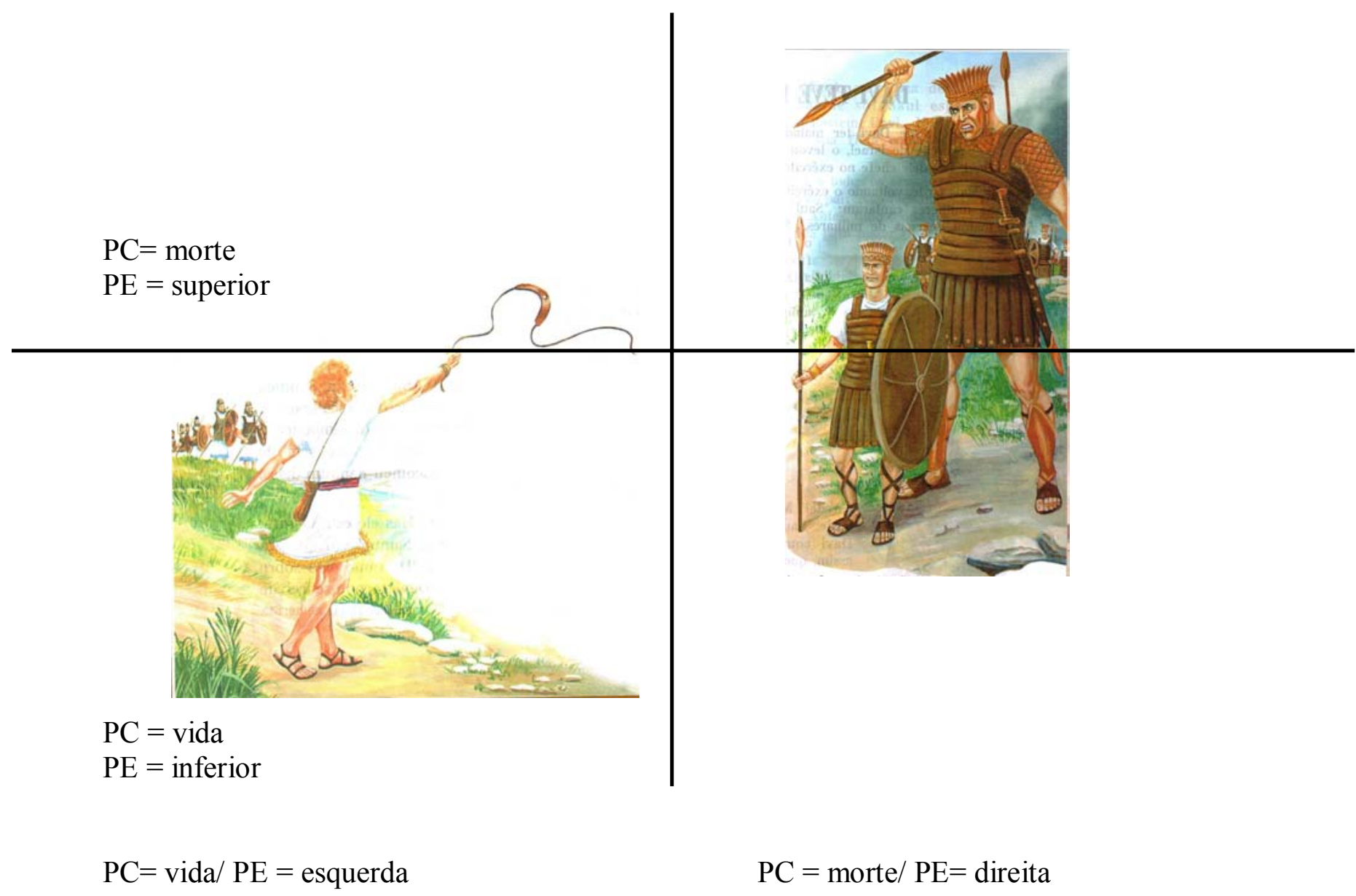

Ilustração 18 MEU LIVRO de Histórias Bíblicas. São Paulo: Sociedade Torre de Vigia de Bíblias e Tratados, 1978. História 58.

Davi apresenta-se disposto no monte inferior, no canto esquerdo do quadro. Davi, com os braços estendidos em posição de ataque, lança a pedra com o auxílio da funda em direção a Golias. Golias também encontra-se disposto em posição de ataque, ao empunhar a lança que arremessaria em direção a Davi.

Podemos ressaltar a diagonal ascendente e barroquizante entre as figuras de Davi e Golias, que ao unir as armas dos dois, faz salientar a força de Davi como um grande herói. 


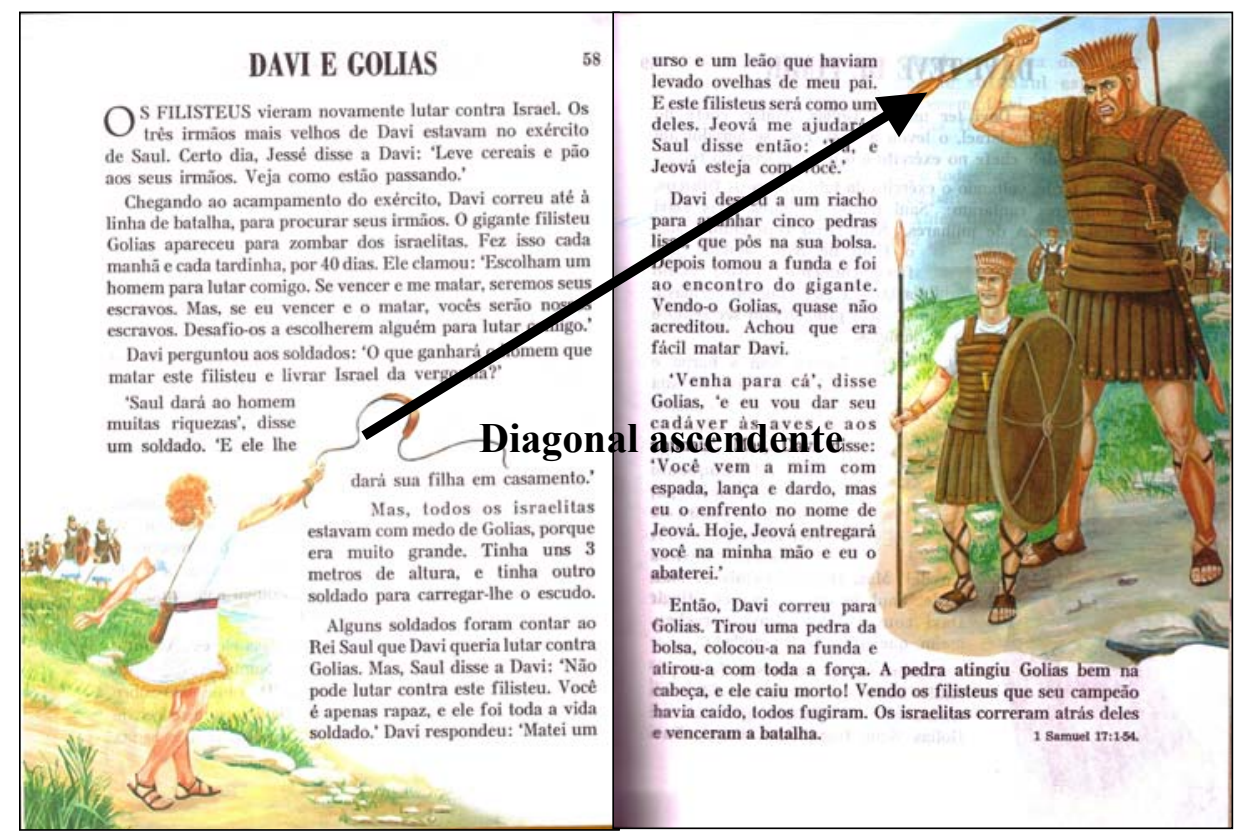

Ilustração 19 MEU LIVRO de Histórias Bíblicas. São Paulo: Sociedade Torre de Vigia de Bíblias e Tratados, 1978.

Davi figurativiza-se por meio da fraqueza de sua compleição física. Um rapaz ruivo, de bela aparência, com trajes e objetos característicos de seu ofício de pastor de ovelhas.

Davi é disposto no espaço tópico da inferatividade (plano inferior), aparentemente disfórico, dada à fragilidade de seus traços físicos, ausência de habilidades bélicas, bem como pela ausência de armas e armaduras características.

Entretanto, diferentemente dá lógica do contra-exemplar observado no discurso do catecismo católico, o texto constrói-se no eixo da inversão da verticalidade pautado pela euforização dos baixos e conseqüente atribuição hierárquica superior a Davi, dado o poder conferido pelo enunciador divino e a sua conjunção com a ideologia religiosa apregoada.

Golias, é disposto disforicamente, embora estivesse de posse das armas e armaduras utilizadas no período (a espada, a lança, o dardo, o escudo carregado pelo escudeiro, uma armadura de cota de malha de escamas imbricadas, a presença de grevas de cobre acima de seus pés e um dardo de cobre entre seus ombros), bem como de habilidades bélicas, pois foi soldado durante toda a vida, somada à compleição de seu corpo, estatura física e feições. 
Ao tomarmos como base as categorias plásticas cromáticas determinadas no enunciado considerado, podemos estabelecer a seguinte relação semi-simbólica: PC vida/ PE claro e PE escuro/ PC morte. Essa categoria pode ser apreendida por meio da claridade e simplicidade das vestes de Davi, por oposição ao cromatismo escuro dado por meio da riqueza ornamental das vestes de Golias. Assim sendo, também podemos estabelecer a categoria plástica monocromático vs. colorido, homologável às categorias semânticas de vida e morte, ao relacionarmos o monocromatismo branco das vestes de Davi por oposição ao colorido e ornamentação do filisteu de Gate.

Com apoio nos estudos sobre Presença de Fontanille e Zilberberg (2001, p. 123-151), dos desenvolvimentos efetuados por Discini (2005c) e do estudo estabelecido por Zilberberg (1992), intitulado Presénce de Wölfflin, buscamos homologar as noções de estilo às de aspectualização do ator da enunciação. A aspectualização do ator, ao ser controlada pelas noções de tempo e andamento, corresponde a uma percepção mais ou menos acelerada dada pelo sujeito que constrói o espaço, ao que corresponde à aspectualização verbal. Depreenderemos assim, um modo de presença em compatibilidade ao sistema de restrições semânticas da totalidade discursiva considerada.

O enunciado do livro instrucional Meu Livro de Histórias Bíblicas, tanto no que concerne à sua substância plástica ou verbal pode ser associado à estética barroca/ pictórica. Os interlocutores, Davi e Golias, projetados no enunciado pelo narrador, são figurativizados de maneira intensa, o objeto desejável e possível coloca-se próximo ao olhar célere do observador pautado pela apreensão do instante.

Observamos assim, a presença de uma iconografia pautada pela superposição de planos, pela profundidade e celeridade dos movimentos que a caracterizam. Ao nos configurarmos na dêixis da indivisão, desconsidera-se o detalhe e reconstitui-se a intensidade de um sujeito dado como presença atualizada. 
Estamos, portanto, em um regime de concentração, no qual os atores do enunciado se figurativizam de maneira intensa por meio de um modo arrebatado de presença.

O éthos da Testemunha de Jeová, contrariamente ao éthos católico, apresenta um tom de voz mais dócil ao se constituir por meio da docilidade ficcional da história de "Davi e Golias".

Esse é o éthos da Testemunha de Jeová, que ao operar com a reduplicação mítica do discurso fundante vai fazer a divulgação religiosa por meio da concretude das figuras, firmando o mito pelo mito.

Um éthos mítico, altivo, superior, autoritário e detentor de uma verdade inquestionável, pois inspirado e respaldado por meio das verdades enunciadas no discurso fundante das Sagradas Escrituras. 


\section{Capítulo III. Análise de textos de divulgação religiosa: enunciatário adulto}

1. Compêndio do Catecismo da Igreja Católica

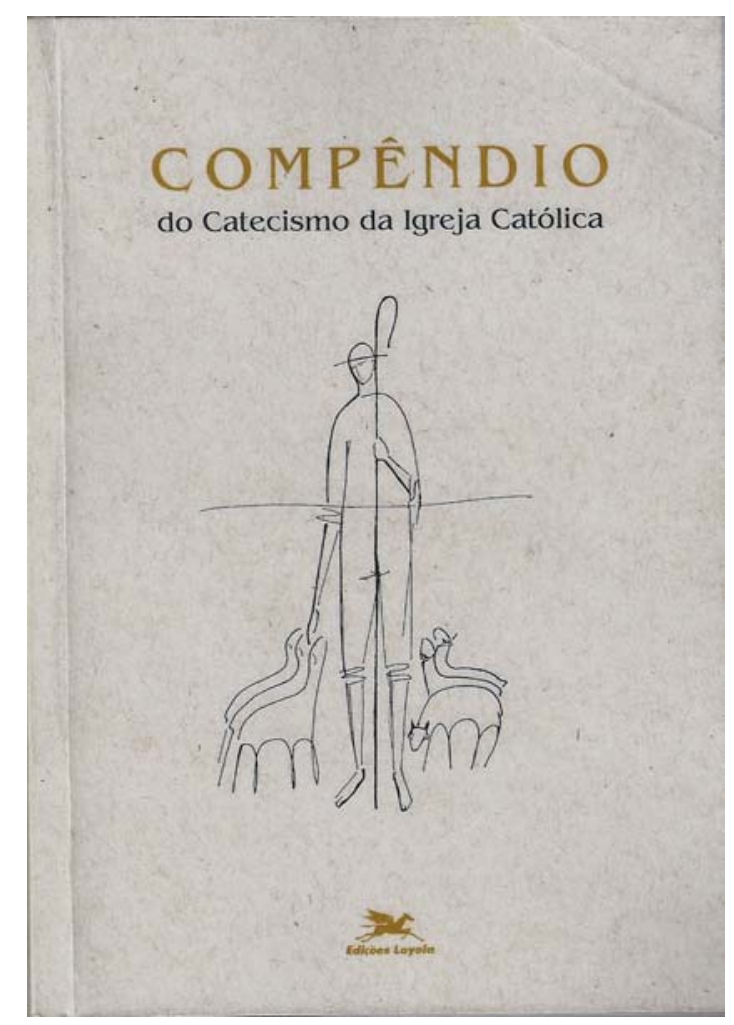

Ilustração 20 Capa do Compêndio do Catecismo da Igreja Católica. ${ }^{13}$

O objetivo deste capítulo é depreender mecanismos de construção do sentido de um texto de divulgação religiosa, o catecismo para adultos da Igreja Católica, designado Compêndio.

O compêndio é um gênero textual. Como faz parte do discurso religioso, será observado como um gênero de divulgação religiosa. Como gênero possui uma estrutura composicional, uma temática e um estilo. Desse parâmetro parte essa análise.

O Compêndio do Catecismo da Igreja Católica confirma o gênero catecismo ao se oferecer como um manual que realiza a exposição completa e integral da doutrina católica

\footnotetext{
${ }^{13}$ BENTO XVI. Compêndio do Catecismo da Igreja Católica. São Paulo: Loyola, 2005.
} 
acerca da fé e dos costumes. As fontes principais de que o gênero catequético se utiliza são: a palavra da Sagrada Escritura, dos Santos Padres, da Liturgia e do Magistério da Igreja.

O catecismo configura-se como um instrumento autorizado para a realização da catequese, tanto de jovens, quanto de adultos. Desse modo, seu público-alvo é formado por: “cada pessoa que, vivendo num mundo dispersivo e de mensagens múltiplas, deseja conhecer o Caminho da Vida, a Verdade confiada por Deus à Igreja do seu Filho" (BENTO XVI, 2005, p. 10).

Temos abaixo um excerto do Catecismo da Igreja Católica: Edição Típica Vaticana:

\begin{abstract}
Bem cedo passou-se a chamar de catequese o conjunto de esforços empreendidos na Igreja para fazer discípulos, para ajudarem os homens a crerem que Jesus é o Filho de Deus, a fim de que, por meio da fé, tenham a vida em nome dele, para educá-los e instruí-los nesta vida, e assim construir o Corpo de Cristo.

A catequese é uma educação da fé das crianças, dos jovens e dos adultos, a qual compreende especialmente um ensino da doutrina cristã, dado em geral de maneira orgânica e sistemática, com o fim de os iniciar na plenitude da vida cristã (JOÃO PAULO II, 2000, p. 14).
\end{abstract}

O Compêndio caracteriza-se como uma versão sintética do conteúdo do Catecismo da Igreja Católica: Edição Típica Vaticana.

Em 11 de outubro de 1992, era promulgado pelo Papa João Paulo II o Catecismo da Igreja Católica: "texto de referência para uma catequese renovada nas fontes vivas da fé" (JOÃO PAULO II, 2000, p. 9). A finalidade da Edição Típica Vaticana apresenta-se como "uma exposição completa e integral da doutrina católica, de tal maneira que cada pessoa possa conhecer o que a Igreja professa e celebra, vive e reza em seu cotidiano" (JOÃO PAULO II, 2000, p. 5). A Edição Típica Vaticana constitui-se, portanto, da exposição "de toda a doutrina católica, tanto em matéria de fé como de moral, para que seja como um texto de referência para os catecismos ou compêndios que venham a ser preparados nas diversas regiões" (JOÃO PAULO II, 2000, p. 8). 
O Compêndio, assim como o Catecismo da Igreja Católica: Edição Típica Vaticana, é um documento católico proveniente de Roma. O Compêndio é de autoria do Papa Bento XVI e o Catecismo da Igreja Católica: Edição Típica Vaticana é de autoria do seu predecessor: João Paulo II. O Compêndio, ao se caracterizar como síntese da versão típica, tem por função divulgar e disseminar os elementos da fé católica e, dessa forma, constitui-se como um mecanismo de divulgação para que o Catecismo da Igreja Católica: Edição Típica Vaticana seja mais conhecido e aprofundado.

Devido aos propósitos divulgadores estabelecidos pelo Compêndio e para uma melhor delimitação entre este e o Catecismo da Igreja Católica, passaremos a designar o Compêndio de "Compêndio divulgador" e o Catecismo da Igreja Católica: Edição Típica Vaticana de "Catecismo de Roma".

O Compêndio divulgador apresenta como temática a exposição, de forma concisa, de todos os elementos essenciais em matéria de fé e moral da Igreja Católica. Não esqueçamos que estes "elementos essenciais" serão considerados efeito de sentido e serão analisados como um modo próprio de argumentar de uma enunciação que quer fazer-crer e fazer-fazer, ou seja, converter.

No que diz respeito à estrutura composicional do Compêndio divulgador, podemos enumerar três características principais: 1) estreita dependência com o Catecismo de Roma; 2) utilização do gênero dialógico; 3) utilização do poder simbólico de imagens retratadas em forma de pintura (ícones).

Essa dependência faz com que o Compêndio não se constitua como uma obra fechada em si mesma e não pretenda substituir a utilização do Catecismo de Roma. Isso é dado a ver no próprio texto do Compêndio divulgador que: "propõe despertar o interesse e fervor para o Catecismo, que com sua sabedoria expositiva e com sua unção espiritual permanece sempre o texto de base da catequese eclesial hoje" (BENTO XVI, 2005, p. 14). 
A estreita dependência do Compêndio divulgador em relação ao Catecismo de Roma manifesta-se por um espelhamento discursivo. Nesse sentido, cabe definir o conceito que estabelecemos como espelhamento discursivo. Tomamos o conceito de espelhamento discursivo como um tipo particular de interdiscursividade que pode ser expandida além do conceito de alusão. Além da incorporação interdiscursiva de temas e figuras do texto fonte (Catecismo de Roma), verifica-se também a presença de um jogo especular em que o texto fonte, tido como modelo, reflete-se no Compêndio divulgador em um completo entrelaçamento diagramático e discursivo.

O Compêndio divulgador nos remete de forma contínua ao Catecismo de Roma, seja pela específica indicação dos números de referência, seja pela relação com a estrutura, desenvolvimento e conteúdo do texto de referência.

Uma característica do Compêndio divulgador é a organização segundo perguntas retóricas.

Vejamos a questão (261):

261. O Batismo é necessáxio para a salvação?

O Batismo é necessário à salvação para aqueles aos quais foi anunciado o Evangelho e que têm a possibilidade de pedir esse sacramento. 1257

Ilustração 21 BENTO XVI. Compêndio do Catecismo da Igreja Católica. São Paulo: Loyola, 2005. p.91.

Observamos a presença de um entrelaçamento diagramático entre as questões propostas pelo Compêndio divulgador e os parágrafos a que elas se referem no Catecismo de Roma. A indicação do número de referência em cromatismo marrom (1257), disposto logo abaixo de cada questão do Compêndio, alude ao parágrafo no qual tal questão se encontra desenvolvida no Catecismo. 
O Senhor mesmo afirma que o Batismo é necessário para a salvação. Também ordenou a seus discípulos que anunciassem o Evangelho e batizassem todas as nações. O Batismo é necessário, para a salvação, para aqueles aos quais o Evangelho foi anunciado e que tiveram a possibilidade de pedir este sacramento. A Igreja não conhece outro meio senão o Batismo para garantir a entrada na bem-aventurança eterna; é por isso que cuida de não negligenciar a missão que recebeu do Senhor, de fazer "renascer da água e do Espírito" todos aqueles que podem ser batizados. Deus vinculou a salvação ao sacramento do Batismo, mas ele mesmo não está vinculado aos seus sacramentos (JOÃO PAULO II, 2000, p. 349-350).

Como vemos, a relação entre o Compêndio divulgador e o Catecismo de Roma não se configura como um mero entrelaçamento diagramático. Temos um entrelaçamento discursivo e uma explicitação do texto de referência: o Catecismo de Roma. Devemos, nesse caso, de acordo com Fiorin (2006, p. 52), falar em intertextualidade. O caráter interdiscursivo, intrínseco aos enunciados contemplados, manifesta-se por um tipo particular de interdiscursividade, determinado por meio de uma relação intertextual entre duas materialidades textuais distintas. Consideraremos por "materialidade textual" os textos do Compêndio divulgador e do Catecismo de Roma, tomados em sentido estrito.

Assim como o Catecismo de Roma, o Compêndio divulgador também se estrutura em quatro partes, "em correspondência com as leis fundamentais da vida em Cristo" (BENTO XVI, 2005, p. 14). Essa articulação do conteúdo em quatro partes retoma a antiga ordem tradicional seguida pelo gênero catequético que fora introduzida pelo Catecismo de São Pio V. Cada parte corresponde a cada um dos quatro dos pilares da fé católica: o Credo, os Sacramentos, os Mandamentos e o Pai-nosso.

Estas são as quatro partes referidas: a) "A profissão de fé"; b) “A celebração do mistério cristão", c) “A vida em Cristo"; d) “A oração cristã".

A primeira parte, denominada "A profissão de fé", apresenta uma síntese da "lex credendi", ou seja, da fé professada pela Igreja Católica. 
Os que pela fé do batismo pertencem a Cristo devem confessar sua fé batismal diante dos homens. Por isso, o Catecismo começa por expor em que consiste a Revelação, pela qual Deus se dirige e se doa ao homem, bem como a fé, pela qual o homem responde a Deus (Seção I). O Símbolo da fé resume os dons que Deus outorga ao homem como Autor de todo bem, como Redentor, como Santificador, e os articula em torno dos "três capítulos de nosso Batismo - a fé em um só Deus: o Pai todo-poderoso, o Criador, Jesus Cristo, seu Filho, nosso Senhor e Salvador, e o Espírito Santo, na Santa Igreja (Seção II)" (JOÃO PAULO II, 2000, p. 16).

A segunda parte, "A celebração do mistério cristão", contém os elementos essenciais da "lex celebrandi".

A segunda parte do Catecismo expõe como a salvação de Deus, realizada uma vez por todas por Cristo Jesus e pelo Espírito Santo, se torna presente nas ações sagradas da liturgia da Igreja (Seção I), particularmente nos sete sacramentos (Seção II) (JOÃ̃ PAULO II, 2000, p. 16).

A terceira parte, "A vida em Cristo", apresenta a evocação da "lex vivendi", ou seja, "o esforço que os batizados fazem para manifestar nos seus comportamentos e nas suas escolhas éticas a fidelidade à fé professada e celebrada" (BENTO XVI, 2005, p. 14).

A terceira parte do Catecismo apresenta o fim último do homem, criado à imagem de Deus: a bem-aventurança e os caminhos para chegar a ela: mediante um agir reto e livre, com a ajuda da fé e da graça de Deus (Seção I); por meio de um agir que realiza o duplo mandamento da caridade, desdobrado nos dez Mandamentos de Deus (Seção II) (JOÃO PAULO II, 2000, p. 17).

A quarta parte, “A oração cristã”, expõe a síntese da "lex orandi", ou seja, da vida de oração. "A exemplo de Jesus, o modelo perfeito de orante, também o cristão é chamado ao diálogo com Deus na oração, cuja expressão privilegiada é o Pai-Nosso, a oração ensinada pelo próprio Jesus" (BENTO XVI, 2005, p. 14).

As quatro partes, por sua vez, apresentam uma ligação entre si: 
O mistério cristão é o objeto da fé (primeira parte); é celebrado e comunicado nos atos litúrgicos (segunda parte); está presente para iluminar e amparar os filhos de Deus em seu agir (terceira parte); fundamenta nossa oração, cuja expressão privilegiada é o "Pai-Nosso", e constitui o objeto de nossa súplica, de nosso louvor e de nossa intercessão (quarta-parte) (JOÃO PAULO II, 2000, p. 10).

Vejamos agora como se constituem as partes de que se compõe o Compêndio divulgador numa perspectiva semiótica.

O destinador-manipulador institui um contrato fiduciário com o destinatário-sujeito por meio do estabelecimento do mistério cristão como objeto de fé. O destinatário-sujeito, por meio de seu fazer persuasivo, ao crer como verdadeiro esse objeto de fé, deve professar a fé em um só Deus: o Pai todo-poderoso, o Criador; Jesus Cristo, seu Filho, nosso Senhor e Salvador; e o Espírito Santo, na Santa Igreja Católica (primeira parte).

O destinatário-sujeito, após ter estabelecido o julgamento epistêmico e professado a crença no mistério cristão, recebe o $\mathrm{O}_{\mathrm{v}}$ "graça divina", fruto das ações sacramentais, por meio do PN de atribuição de competência realizado pelo destinador-manipulador (segunda parte).

Por conseguinte, o destinatário-sujeito, ao ter adquirido o $\mathrm{O}_{\mathrm{v}}$ "graça divina", obtém o dom necessário para a realização da performance do "agir cristão" mediante a prática dos mandamentos (terceira parte). Tal agir é caracterizado como "um agir reto e livre, com a ajuda da fé da graça de Deus" (JOÃO PAULO II, 2000, p. 17).

Por fim, na última parte, “A oração cristã”, o destinatário-sujeito recebe o $\mathrm{O}_{\mathrm{m}}$ "poder e força”, que faz com que ele, por meio da figura exemplar de Jesus, mantenha-se em conjunção com o $\mathrm{O}_{\mathrm{v}}$ "graça divina" e possa alcançar a salvação eterna.

$\mathrm{Na}$ tentativa de delinearmos o modo de presença, o éthos do ator da enunciação da unidade (unus), devemos levar em conta a totalidade (totus) da qual fazem parte as seções que constituem o Compêndio divulgador. Primeiramente, observaremos a sua constituição diagramática. 


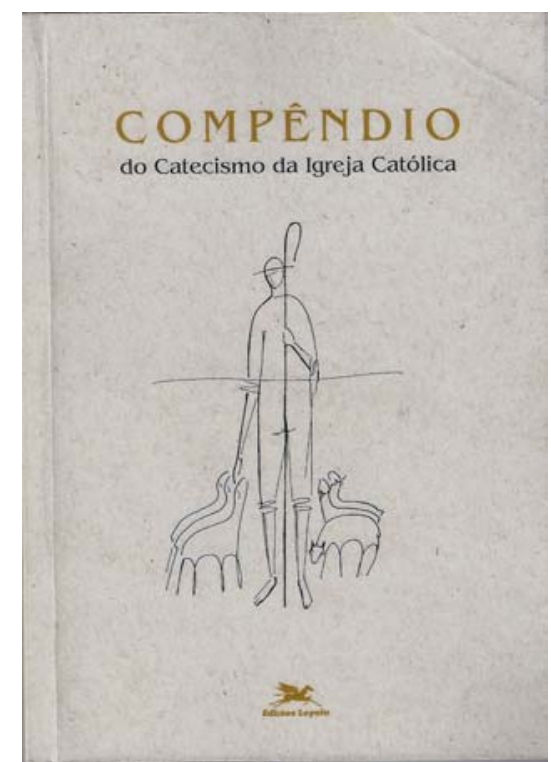

Ilustração 22 Capa do Compêndio do Catecismo da Igreja Católica.

Ao observarmos atentamente a capa do Compêndio divulgador, verificamos que ela se constitui por uma composição diagramática pautada pelo efeito de simplicidade, em correspondência aos ideais de simplicidade, brevidade, clareza e integridade propostos pelo próprio compêndio.

A materialidade de que se constitui a capa da brochura, determinada pela escolha do tipo de papel de cromatismo pardo, confirma o efeito de sentido de simplicidade proposto pelo PC (plano do conteúdo). Já o PE (plano de expressão) de que se constitui a capa apresenta o título síntese do conteúdo disposto no alto em letras: com fonte de tamanho maior, em caixa alta e de cromatismo dourado. A referência ao Catecismo de Roma é determinada no plano de expressão por um efeito de simplicidade, materializado pelas letras em cromatismo preto, com maiúsculas apenas nas iniciais. A indicação da editora, disposta ao final da capa, também segue o mesmo cromatismo dourado utilizado no título.

Observamos também a presença da figurativização de um pastor de ovelhas com um cajado a guiar o seu rebanho, o que confere alto índice de iconicidade a esse enunciado da capa. Mais uma vez, o efeito de simplicidade, proposto por um plano de expressão composto 
por linhas marcadas por traços simples e estilo linear, reforça também alguns aspectos que caracterizam o plano do conteúdo: Cristo, figurativizado como o pastor de ovelhas, que conduz e protege seus fiéis (ovelhas), por meio da autoridade de seu cajado e da cruz redentora (disposta na parte central da imagem visual), conferindo a eles a "graça divina" e a salvação eterna.

Como recursos argumentativos que propõem conferir o caráter de instrumento autorizado ao Compêndio, notamos a aprovação da Conferência Nacional dos Bispos do Brasil - CNBB, tal como consta na contracapa e o Motu Próprio. Abaixo, reproduzimos a aprovação da CNBB:

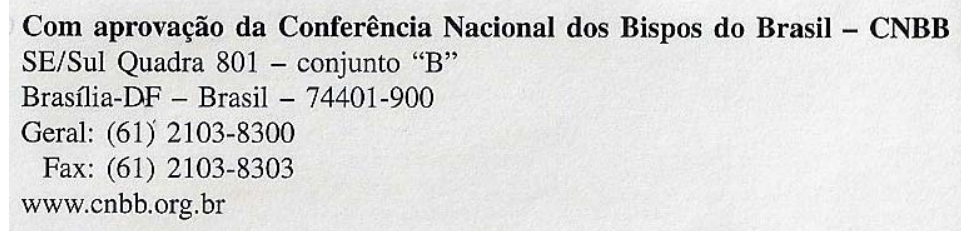

Ilustração 23 BENTO XVI. Compêndio do Catecismo da Igreja Católica. São Paulo: Loyola, 2005. p.4.

O Compêndio foi promulgado e aprovado para publicação em 28 de junho de 2005 pelo Motu Próprio do Papa Bento XVI. Segue a reprodução na íntegra do Motu Próprio, que concretiza o argumento de autoridade para o Compêndio divulgador. 


\section{Motu Proprio \\ para a aprovação e a publicação do Compêndio do Catecismo da Igreja Católica}

Aos Veneráveis Irmãos Cardeais, Patriarcas, Arcebispos, Bispos, Presbiteros, Diáconos e a todos os membros do Povo de Deus.

Há vinte anos, iniciava-se a elaboração do Catecismo da Igreja Católica, que foi pedido pela Assembléia Extraordinária do Sínodo dos Bispos, na ocasião do vigésimo aniversário da conclusão do Concílio Ecumênico Vaticano II. Agradeço infinitamente ao Senhor Deus por ter dado à Igreja esse Catecismo, promulgado em 1992 pelo meu venerável e amado Predecessor, - Papa João Paulo II.

A grande atualidade e preciosidade deste dom é confirmada pela recepção positiva que ele teve no episcopado, ao qual era dirigido antes de tudo como texto de referência segura e autêntica para o ensino da Doutrina Católica e, em especial, para a elaboração de catecismos locais. Mas também é confirmada pela recepção favorável por parte de todos os segmentos do Povo de Deus, que puderam conhecê-lo e apreciá-lo nas mais de cinqüenta linguas em que já foi traduzido.

Agora, com grande alegria, aprovo e promulgo o Compêndio desse Catecismo.

Ele foi vivamente desejado pelos participantes do Congresso Catequético Internacional de outubro de 2002, que assim se fizeram intérpretes de uma exigência muito difundida na Igreja. O meu saudoso Predecessor, acolhendo esse desejo, decidiu a sua preparaçâo em fevereiro de 2003, confiando a sua redação a uma Comissão

Ilustração 24 BENTO XVI. Compêndio do Catecismo da Igreja Católica. São Paulo: Loyola, 2005. p.9. 
restrita de Cardeais por mim presidida e ajudada por alguns especialistas colaboradores. No decorrer dos trabalhos, um projeto desse Compêndio foi submetido ao juízo de todos os Eminentíssimos Cardeais e dos Presidentes das Conferências Episcopais, que, na maioria absoluta, o acolheram e avaliaram positivamente.

O Compêndio, que agora apresento a toda a Igreja, é uma síntese fiel e segura do Catecismo da Igreja Católica. Ele contém, de forma concisa, todos os elementos essenciais e fundamentais da fé da Igreja, constituindo, como tinha desejado meu Predecessor, uma espécie de vademecum, que dá a possibilidade às pessoas, crentes e não-crentes, de abarcarem, numa visão de conjunto, o panorama inteiro da fé católica.

Ele espelha fielmente, na estrutura, nos conteúdos e na linguagem, o Catecismo da Igreja Católica, que encontrará nesta síntese uma ajuda e um estímulo para ser mais conhecido e aprofundado.

Portanto, confio este Compêndio antes de tudo à Igreja inteira e a cada cristão em particular, para que, graças a ele, possa reencontrar, neste terceiro milênio, novo impulso no esforço renovado de evangelização e de educação da fé, que deve caracterizar cada comunidade eclesial e cada crente em Cristo, não importando a idade e a nação à qual pertença.

Mas este Compêndio, pela sua brevidade, clareza e integridade, dirige-se a cada pessoa que, vivendo num mundo dispersivo e de mensagens múltiplas, deseja conhecer o Caminho da Vida, a Verdade confiada por Deus à Igreja do seu Filho.

Lendo este instrumento autorizado, que é o Compêndio, cada um possa, com a especial intercessão de Maria Santíssima, Mãe de Cristo e da Igreja, reconhecer e acolher sempre mais a inesgotável beleza, unicidade e atualidade do Dom por excelência feito por Deus à humanidade: Seu único Filho, Jesus Cristo, que é "o Caminho, a Verdade e a Vida" (Jo 14,6).

Dado no dia 28 de junho de 2005, vigília da Solenidade dos Santos Pedro e Paulo, primeiro ano de Pontificado.

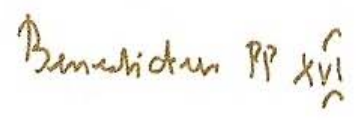

10

Ilustração 25 BENTO XVI. Compêndio do Catecismo da Igreja Católica. São Paulo: Loyola, 2005. p.10.

O Motu Próprio $($ do latim $=$ de própria iniciativa) constitui uma Carta Apostólica escrita e emitida por iniciativa do Romano Pontífice, para aprovação e publicação do Compêndio divulgador. Tal carta é dirigida aos veneráveis Irmãos e Cardeais, Patriarcas, 
Arcebispos, Bispos, Diáconos e todos os membros do Povo de Deus. Ela se apresenta como um texto expositivo que tem por objetivo buscar a adesão do enunciatário por meio do estabelecimento de um fazer-saber. O enunciador institui uma exposição das razões pelas quais se confirma o caráter autorizado desse instrumento de evangelização e de educação da fé. O fazer-saber realiza-se como um "programa de uso" do enunciador que busca, por intermédio do fazer interpretativo do enunciatário, fazer com que este reconheça a autoridade e veracidade desse instrumento de transmissão da fé católica, mediante a aprovação e promulgação pelo supremo líder espiritual da Igreja Católica, o Patriarca de Roma: o Papa.

O caráter autorizado desse instrumento catequético é enfatizado por meio da figura do brasão e da assinatura pessoal de Sua Santidade o Papa Bento XVI.

Observemos o brasão do Papa Bento XVI, presente na abertura do Motu Próprio:

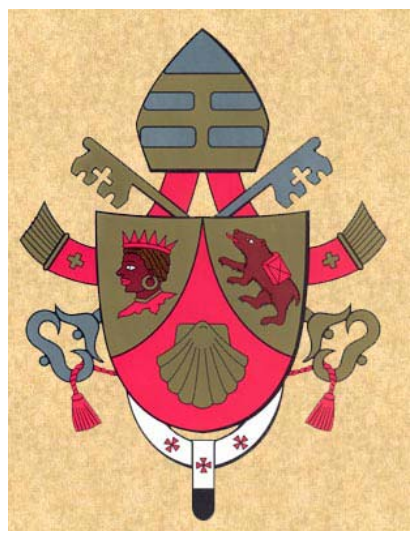

Ilustração 26 Brasão de Sua Santidade o Papa Bento XVI. In: BENTO XVI. Compêndio do Catecismo da Igreja Católica. São Paulo: Loyola, 2005. p. 9.

O escudo do Papa Bento XVI apresenta-se sob a figura de um cálice, umas das formas mais utilizadas pela heráldica eclesiástica. Ele possui em seu interior um cromatismo vermelho com ornamentos dourados. Esse cromatismo está associado simbolicamente às cores de Roma que representam o sangue e o ouro.

No campo central e principal do escudo, de cor vermelha, observamos dois relevos laterais nos ângulos superiores que recebem a denominação de "capa", tida como símbolo de 
religião. Nesses relevos laterais podemos observar dois simbolismos. No ângulo superior esquerdo do brasão, verificamos o antigo símbolo da Diocese de Frisinga representado por uma cabeça de um mouro de colar, lábios e coroa vermelhos. No ângulo superior direito, temos um urso de cor escura a carregar um fardo em seu dorso. Por meio desse simbolismo encontra-se representado o peso do fardo do episcopado.

No ponto central do escudo, notamos uma concha dourada de triplo simbolismo: a) um simbolismo teológico, ao pretender recordar uma lenda atribuída a Santo Agostinho; b) símbolo de indicação do peregrino; c) é também o símbolo presente no brasão do Antigo Mosteiro de Schotten, na Baviera, com o qual Bento XVI se sente espiritualmente relacionado.

Em volta do escudo estão os simbolismos que conferem grau, dignidade e jurisdição ao Papa. Dentre eles, verificamos duas chaves colocadas em forma de cruz de Santo André, uma de ouro e outra de prata, símbolos do poder espiritual e temporal do Papa. No alto do brasão há uma mitra pontifícia (insígnia eclesiástica) de prata com três faixas de ouro, que representam os poderes de Ordem, Jurisdição e Magistério. As três faixas estão ligadas de forma vertical entre si pela parte central, o que indica a unidade dos três poderes citados na mesma pessoa. Observamos também a utilização do pálio, distintivo litúrgico típico do Sumo Pontífice, de cromatismo branco e cruzes vermelhas, com a indicação do cargo de pastor a conduzir suas ovelhas (fiéis).

Após o Motu Próprio, há a introdução do Compêndio divulgador, que busca, mediante a utilização de um texto expositivo, apresentar a estrutura composicional da obra.

Vejamos abaixo, a título de exemplo, como se estrutura a segunda parte, “A celebração do Mistério cristão", a qual se estabeleceu como recorte analítico. Essa parte, tal como as outras três partes: “A profissão de fé” (Parte I), “A vida em Cristo" (Parte III) e “A oração cristã" (Parte IV), que compõem o Compêndio divulgador, está organizada deste 
modo: a) seções; b) capítulos; c) artigos. Cada parte é articulada em torno de duas seções (Seção I e II). Cada seção é estruturada em capítulos e cada capítulo se subdivide em artigos.

\section{SEGUNDA PARTE: A CELEBRAÇÃO DO MISTÉRIO CRISTÃo}

\section{Primeira seção: A Economia Sacramental}

Capítulo primeiro: O MISTÉRIO PASCAL NO TEMPO DA IGREJA

Artigos: Liturgia - obra da Santíssima Trindade

O mistério pascal nos sacramentos da Igreja

Capítulo segundo: A CELEBRAÇÃO SACRAMENTAL DO MISTÉRIO PASCAL Artigos: Celebrar a liturgia da Igreja

Quem celebra?

Como celebrar?

Quando celebrar?

Onde celebrar?

Diversidade litúrgica e unidade do mistério

Segunda seção: Os sete sacramentos da Igreja: Septem Ecclesiae Sacramenta

\section{Capítulo primeiro: OS SACRAMENTOS DA INICIAÇÃO CRISTÃ}

Artigos: O sacramento do Batismo

O sacramento da Confirmação

O sacramento da Eucaristia 


\section{Capítulo segundo: OS SACRAMENTOS DA CURA}

Artigos: O sacramento da Penitência e da Reconciliação

O sacramento da Unção dos Enfermos

\section{Capítulo terceiro: OS SACRAMENTOS A SERVIÇO DA COMUNHÃO E DA MISSÃO}

Artigos: O sacramento da Ordem

O sacramento do Matrimônio

\section{Capítulo quarto: AS OUTRAS CELEBRAÇÕES LITÚRGICAS}

Artigos: Os sacramentais

Os funerais cristãos

As lições presentes nos artigos estruturam-se por meio de uma heterogeneidade mostrada e marcada: temos perguntas de um narrador e respostas de um narratário em uma simulação de discurso direto. A noção de heterogeneidade foi estabelecida por Authier-Revuz (1982), com base nos princípios bakthinianos. A heterogeneidade corresponde às distintas configurações pelas quais o discurso é atravessado por diferentes vozes. Essa noção está exposta, na lição, de uma forma mostrada e marcada que corresponde à presença do outro na cadeia do discurso, explicitamente demarcado por meio de marcas lingüísticas.

A estrutura composicional do texto retoma a forma do antigo gênero literário catequético estruturado em perguntas e respostas. A utilização da heterogeneidade mostrada e marcada apresenta três finalidades essenciais: a) produzir um simulacro dialógico de um encontro catequético entre mestre e discípulo; b) reduzir o conteúdo ao essencial; c) favorecer a assimilação e memorização dos conteúdos expostos. 
Observamos também a utilização de imagens iconográficas cristãs para marcar a articulação do Compêndio.

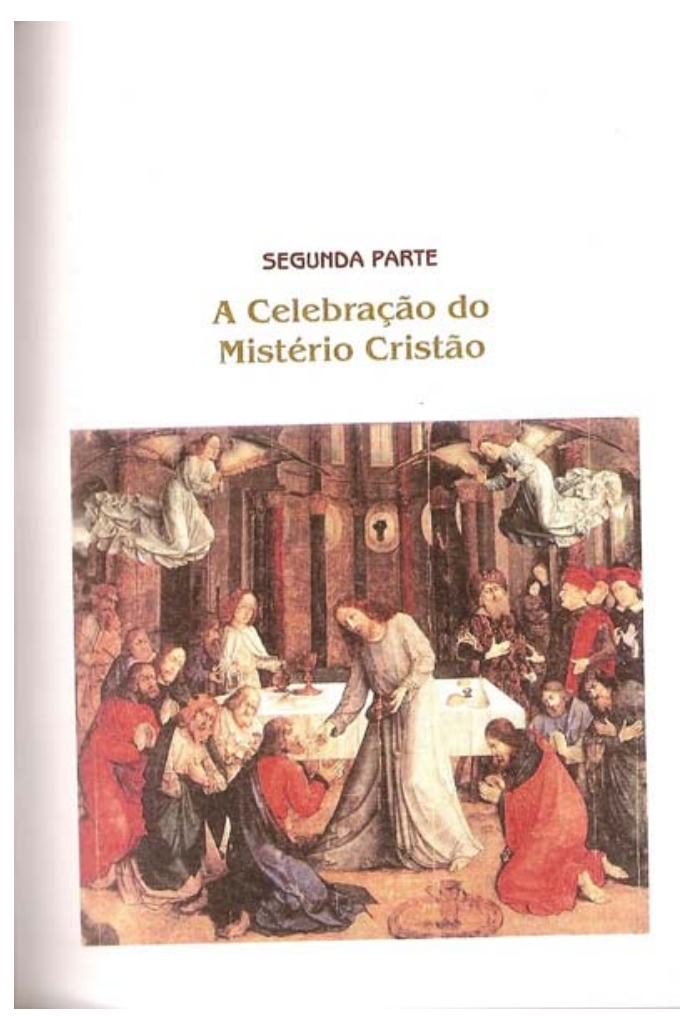

Ilustração 27 BENTO XVI. Compêndio do Catecismo da Igreja Católica. São Paulo: Loyola, 2005. p. 75.

As imagens possuem função estética, ou seja, função de ornamento, além de contribuírem para a articulação dos conteúdos e das seções do Compêndio. A utilização das mesmas na pregação evangélica é eficaz como mecanismo argumentativo, graças ao caráter de iconicidade, dinamismo de comunicação e transmissão de conteúdos que elas proporcionam à mensagem catequética.

Por fim, o Compêndio divulgador apresenta em apêndice os seguintes itens: a) Orações comuns (Sinal da Cruz, Glória ao Pai, Ave Maria, Salve-Rainha, etc.); b) Fórmulas de doutrina católica (Os mandamentos de caridade, A regra de ouro (Mt 7, 12), As Bemaventuranças (Mt 5, 3-12), As virtudes teologais, As virtudes cardeais, Os dons do Espírito 
Santo, Os frutos do Espírito Santo, Os mandamentos da Igreja, As obras de misericórdia corporal, As obras de misericórdia espiritual, Os vícios capitais e Os novíssimos).

Ressaltamos também o emprego de orações em latim que acompanham aquelas em português:

\section{Sinal da Cruz}

Em nome do Pai e do Filho

e do Espírito Santo. Amém.

(BENTO XVI, 2005, p. 183)

O apêndice é seguido ainda de um índice analítico para uma busca rápida de conteúdos no texto.

\section{1 "Segunda Seção: Os Sete Sacramentos da Igreja”: Análise semiótica}

Voltemos à unidade recortada: a segunda seção (Os Sete Sacramentos da Igreja) extraída da segunda parte (A celebração do mistério cristão) do Compêndio divulgador, da totalidade discursiva Católica. ${ }^{14}$

\footnotetext{
14 Devido à extensão acentuada dessa seção do Compêndio optamos por inserir seu conteúdo integral apenas na seção ANEXO C dessa dissertação.
} 


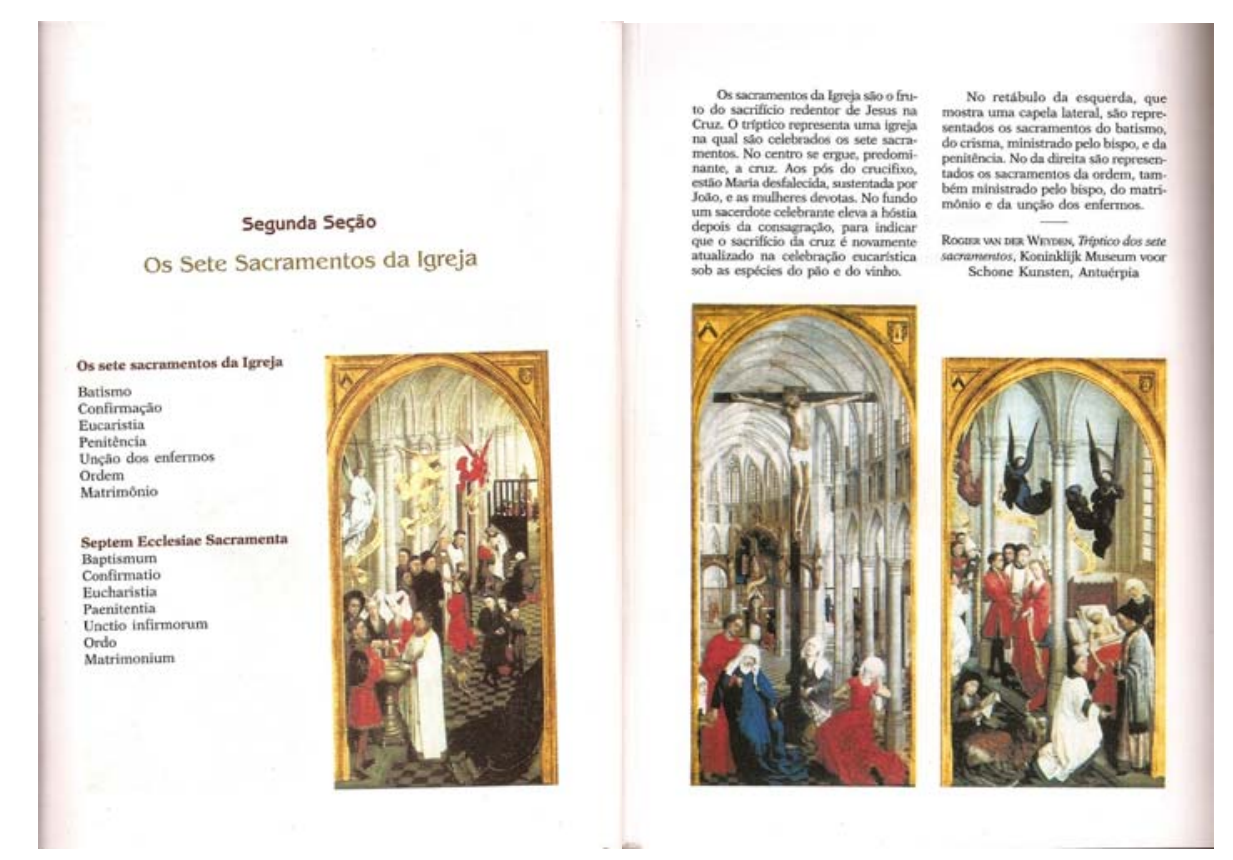

Ilustração 28 BENTO XVI. Compêndio do Catecismo da Igreja Católica. São Paulo: Loyola, 2005. p. 87-88.

Tomamos o texto da lição considerada como um todo organizado de sentido, um enunciado sincrético, pautado pela complementaridade mútua entre o enunciado verbal e o visual. No que concerne à coerção genérica de sua exposição, o enunciado considerado apresenta a seguinte estrutura: a) abertura da lição com a presença da imagem visual do Tríptico dos sete sacramentos, de Rogier Van der Weyden; b) título da seção em cromatismo dourado e vermelho; c) referência sumária aos sete sacramentos em português e latim; d) disposição do texto da lição em capítulos e artigos; e) desenvolvimento do conteúdo dos artigos com a simulação de um discurso direto (perguntas e respostas); f) entrelaçamento discursivo entre as questões propostas pelo Compêndio divulgador e os parágrafos a que elas se referem no Catecismo de Roma; g) citações bíblicas como "argumento de autoridade".

O visual sincretizado ao verbal no Compêndio divulgador é discursivizado como expansão das figuras verbais. Devido ao predomínio do sincretismo por convergência, o icônico em relação de complementaridade metonímica com o verbal viabiliza a leitura linear e facilitada, própria ao tom professoral. 
A estrutura elementar, organização estrutural mínima que permeia o discurso da seção catequética considerada, pode ser estabelecida mediante a relação entre dois termos-objetos: humano (profano) vs. divino (sagrado).

Os termos categoriais são assim investidos axiologicamente: o termo humano, entendido no discurso do Compêndio como aqueles que vivem em um "mundo dispersivo e de mensagens múltiplas” (BENTO XVI, 2005, p. 10), é investido de valor disfórico. O termo divino é investido pelo valor eufórico, pela conformidade ao sistema de crenças vigente que se manifesta pelo desejo de "conhecer o caminho da Vida, a Verdade confiada por Deus à Igreja do Seu Filho" (BENTO XVI, 2005, p.10).

Ao estabelecer uma sintaxe sumária capaz de apreender as operações fundamentais que determinam o sentido, definimos, para a posição $\mathrm{S}_{1}$, a dêixis integração, e que se articula ao termo divino. O cristão, tendo adquirido os saberes e dons necessários ao adequado agir cristão (mistério sacramental), é integrado ao sistema de valores proposto. Para a posição $\mathrm{S}_{2}$, definimos a dêixis transgressão, articulada ao termo humano. Nela o sujeito constitui-se como transgressor dos valores propostos pelo catolicismo, pois, uma vez motivado por interesses humanos, deixa-se levar pela prática do pecado.

Vejamos como esses termos são estabelecidos por meio do quadrado semiótico:

$$
\begin{array}{lc}
\mathbf{s}_{\mathbf{1}} & \mathbf{s}_{\mathbf{2}} \\
\text { Divino (sagrado) } & \text { Humano (profano) }
\end{array}
$$
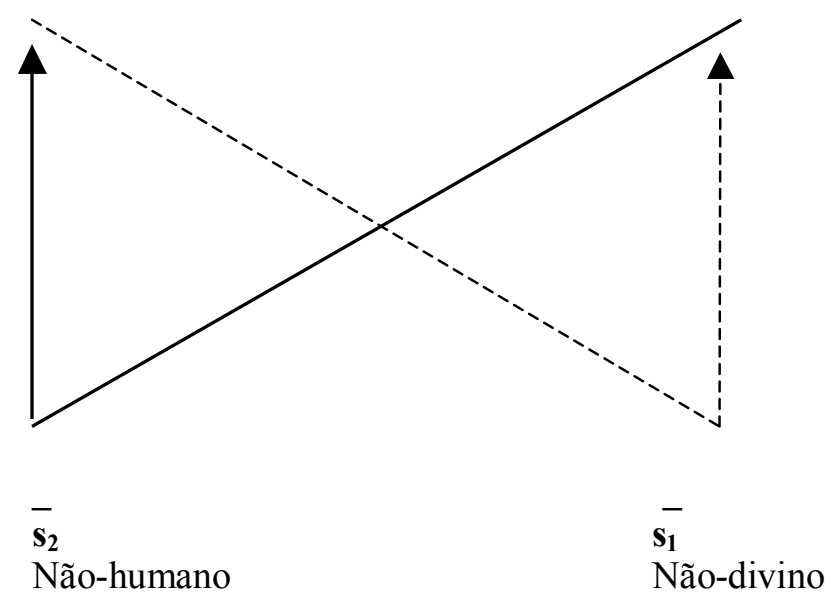
Notamos, por meio do Compêndio, o estabelecimento de uma dimensão cognitiva do discurso, desenvolvida mediante a apresentação e exposição sumária dos conteúdos essenciais e fundamentais da doutrina católica em matéria de fé e costumes. Assim sendo, voltemos a atenção ao nível narrativo, tomando como base estes dois programas narrativos:

\section{PN1}

$\mathrm{S}_{1} \rightarrow \mathrm{S}_{2} \cap \mathrm{O}_{\mathrm{v}}$

$\mathrm{S}_{1}=$ Destinador-manipulador (Papa)

$\mathrm{S}_{2}=$ Destinatário (Agentes religiosos divulgadores)

$\mathrm{O}_{\mathrm{v}}=$ poder-fazer (transmitir o saber)

PN2

$\mathrm{S}_{1} \rightarrow \mathrm{S}_{2} \cap \mathrm{O}_{\mathrm{v}}$

$\mathrm{S}_{1}=$ Destinador-manipulador (agente religioso divulgador)

$\mathrm{S}_{2}=$ Destinatário (sujeito católico: catecúmeno)

$\mathrm{O}_{\mathrm{v}}=$ saber transmitido

No primeiro programa narrativo (PN1), o destinador-manipulador (Papa), revestido da autoridade que the foi outorgada discursivamente, estabelece, por meio da modalidade factitiva (fazer-fazer), um fazer persuasivo através do qual manipula os agentes religiosos divulgadores a transmitirem o objeto modal (saber a respeito da doutrina católica) aos catecúmenos.

No segundo programa narrativo (PN2), o destinador-manipulador (agente religioso divulgador) estabelece um fazer cognitivo por meio do qual busca realizar a transformação de estados do destinatário-sujeito, no que corresponde à transmissão do objeto modal saber 
transmitido. O destinador-manipulador, tendo por finalidade adquirir a adesão lógica do enunciatário e realizar a transformação de saberes do sujeito, faz com que este, inicialmente disjunto do saber a respeito do mistério sacramental, busque a conjunção.

A manipulação cognitiva desenvolve-se mediante a realização do fazer-saber, como programa de uso, com a exposição dos significados, atos e efeitos das ações sacramentais. Desse modo, o destinador-manipulador busca estabelecer um contrato fiduciário pelo qual deseja fazer a integração do destinatário-sujeito ao sistema de coerções semióticas proposto pela prática católica. O destinatário-sujeito, ao realizar sua posterior adesão lógica, busca a conjunção com o saber a respeito do mistério sacramental, com o qual estaria em disjunção.

No PN prévio, que remonta à primeira parte do Compêndio divulgador, há o estabelecimento do fazer persuasivo do destinador-manipulador, que busca convocar o destinatário-sujeito para a vida evangélica. Esse PN prévio desenvolve-se mediante a apresentação do mistério cristão, com a exposição da fé professada pela Igreja Católica. O destinatário-sujeito (catecúmeno) realiza o julgamento epistêmico e professa a crença no mistério cristão determinado como objeto de fé. Por sua vez, o catecúmeno deve receber o $\mathrm{O}_{\mathrm{v}}$ "graça divina", fruto das ações sacramentais (Parte II), a fim de que ele possa ser integrado ao sistema de valores católico e adquirir o dom necessário para a realização da performance do "agir cristão", com a prática dos mandamentos (Parte III), e, conseqüentemente, adquirir a salvação eterna.

Por conseguinte, o Compêndio funciona como um PN de uso para que se possa obter o PN de base representado pela aquisição do $\mathrm{O}_{\mathrm{v}}$ "graça divina".

Assim, podemos considerar o enunciado catequético como um texto instrucional programador, na medida em que possibilita ao destinatário a aquisição de uma competência: “saber ser católico". 
A catequese litúrgica a respeito das ações sacramentais tem por objetivo introduzir e apresentar ao catecúmeno a "economia sacramental" da Igreja Católica.

A economia sacramental consiste em comunicar os frutos da redenção de Cristo mediante a celebração dos sacramentos da Igreja, principalmente da Eucaristia, "até que ele venha" (1 Cor 11, 26) (BENTO XVI, 2005, p. 79).

Desse modo, a catequese litúrgica busca comunicar o saber "fundamental e comum a toda Igreja no tocante à liturgia como mistério e como celebração" (Seção I) e "os sete sacramentos e os sacramentais" (Seção II) (cf. JOÃO PAULO II, 2000, p. 303).

Tomemos como base a Seção II, a qual estabelecemos como recorte textual para a realização dessa análise.

O destinador manipulador busca transmitir ao destinatário-sujeito o saber acerca da comunicação sacramental do mistério de Cristo.

Dentro do discurso católico, “os sacramentos são sinais eficazes da graça, instituídos por Cristo e confiados à Igreja, por meio dos quais nos é dispensada a vida divina" (JOÃO PAULO II, 2000, p. 319).

Conforme delineamos no primeiro capítulo dessa dissertação, a Igreja Católica possui sete sacramentos: Batismo, Confirmação, Eucaristia, Penitência, Unção dos Enfermos, Ordem e Matrimônio. Os sacramentos apresentam a seguinte distinção: sacramentos da iniciação cristã (Batismo, Confirmação e Eucaristia); sacramentos da cura (Penitência e Unção dos Enfermos); sacramentos a serviço da comunhão e da missão (Ordem e Matrimônio).

A comunicação da graça divina, fruto dos sacramentos, é condição insubstituível do agir cristão (Parte III):

$\mathrm{S}_{1} \rightarrow\left(\mathrm{S}_{2} \cup \mathrm{O}_{\mathrm{m}}\right) \rightarrow\left(\mathrm{S}_{2} \cap \mathrm{O}_{\mathrm{m}}\right)$

$\mathrm{S}_{1}=$ cristão 
$\mathrm{S}_{2}=$ cristão

$\mathrm{O}_{\mathrm{m}}=$ querer e saber agir como cristão católico

Novamente, a comunicação da "graça divina", transformação principal operacionalizada por esse enunciado, se estabelece por meio da realização dos seguintes PNs de base:

PN1

$\mathrm{S}_{1} \rightarrow\left(\mathrm{S}_{2} \cup \mathrm{O}_{\mathrm{v}}\right) \rightarrow\left(\mathrm{S}_{2} \cap \mathrm{O}_{\mathrm{v}}\right)$

$\mathrm{S}_{1}=$ Jesus Cristo/A Palavra Revelada

$\mathrm{S}_{2}=$ agente religioso

$\mathrm{O}_{\mathrm{m}}=$ poder-fazer (transmitir o saber para obtenção da "graça divina")

PN2

$\mathrm{S}_{1} \rightarrow\left(\mathrm{S}_{2} \cup \mathrm{O}_{\mathrm{v}}\right) \rightarrow\left(\mathrm{S}_{2} \cap \mathrm{O}_{\mathrm{v}}\right)$

$\mathrm{S}_{1}=$ agente religioso

$\mathrm{S}_{2}=$ catecúmeno

$\mathrm{O}_{\mathrm{v}}=$ "graça divina"

No programa narrativo de base (PN1), Jesus Cristo, através da Palavra Revelada, transmite o objeto modal $\left(\mathrm{O}_{\mathrm{m}}\right)$ "poder-fazer", para que o agente religioso possa comunicar o saber necessário e, assim, o catecúmeno possa adquirir o $\mathrm{O}_{\mathrm{v}}$ "graça divina".

Dentro do discurso católico, a Sagrada Escritura e a Tradição apostólica constituem duas modalidades de transmissão do mistério de Cristo: 
A Sagrada Escritura é a Palavra de Deus enquanto redigida sob a moção do Espírito Santo.

Quanto à Sagrada Tradição, ela transmite integralmente aos sucessores dos apóstolos a Palavra de Deus confiada por Cristo Senhor e pelo Espírito Santo aos apóstolos para que sob a luz do Espírito de Verdade, eles, por sua pregação, fielmente a conservem, exponham e difundam (JOÃO PAULO II, 2000, p. 35).

A transmissão da revelação divina é determinada no discurso Igreja católica pela sucessão apostólica.

Essa transmissão viva, realizada no Espírito Santo, é chamada de Tradição, pois é distinta da Sagrada Escritura, embora intimamente ligada a ela. Por meio da Tradição, "a Igreja em sua doutrina, vida e culto, perpetua e transmite a todas as gerações tudo o que ela é, tudo o que crê". "O ensinamento dos Santos Padres testemunha a presença vivificante desta Tradição, cujas riquezas se transfundem na praxe e na vida da Igreja crente e orante" (JO ÃO PAULO II, 2000, p. 34).

Vejamos, por meio dos seguintes versículos (Mt 28, 16-20), a autoridade concedida por Jesus aos primeiros apóstolos:

\begin{abstract}
A aparição de Jesus na Galiléia e a missão universal - ${ }_{16}$ Os onze discípulos caminharam para a Galiléia, à montanha que Jesus lhes determinara. 17 Ao vê-lo, prostraram-se diante dele. Alguns, porém, duvidaram. ${ }_{18}$ Jesus, aproximando-se deles, falou: Todo o poder foi me dado no céu e sobre a terra. ${ }_{19}$ Ide, portanto, e fazei com que todas as nações se tornem discípulos, batizando-as em nome do Pai, do Filho e do Espírito Santo 20 e ensinando-as a observar tudo quanto vos ordenei. E eis que estou convosco todos os dias, até a consumação dos séculos (BÍBLIA de Jerusalém, 2004, p. 1758).
\end{abstract}

No PN2, observamos a transformação operacionalizada pelo fazer cognitivo do agente religioso sobre o catecúmeno, para que este último, ao adquirir o saber a respeito do mistério sacramental, entre em conjunção com o $\mathrm{O}_{\mathrm{v}}$ "graça divina".

Observamos, por meio do enunciado do Compêndio, a exposição da transformação de estados do sujeito-cristão, que, inicialmente disjunto do $\mathrm{O}_{\mathrm{v}}$ "graça divina", busca a sua 
conjunção. Essa conjunção se manifesta por meio da aquisição do saber a respeito da comunicação ritualística dos sacramentos.

A administração dos sete sacramentos é instituída no enunciado por meio de uma seqüência de PNs de uso, nos quais temos instaurados programas de doação de competência, com a atribuição dos saberes a respeito dos dons de Cristo.

Para os que crêem em Cristo os sacramentos são necessários para a salvação, embora não sejam conferidos todos a cada fiel individualmente, porque conferem as graças sacramentais, o perdão dos pecados, a adoção como filhos de Deus, a conformação a Cristo Senhor e a pertença à Igreja. O Espírito Santo cura e transforma aqueles que os recebem (BENTO XVI, 2005, p. 81).

Vejamos como essa seqüência de PNs de uso, em correspondência à administração do saber a respeito de cada sacramento, se concretizam textualmente na Seção II do Compêndio divulgador.

Os sacramentos da iniciação cristã "estabelecem os fundamentos da vida cristã: os fiéis, renascidos no Batismo, são fortalecidos pela Confirmação e são nutridos pela Eucaristia” (BENTO XVI, 2005, p. 89).

Inicialmente, tomemos como base a instauração do saber a respeito do sacramento do batismo, fundamento de toda a vida cristã, porta da vida no Espírito (vitae spiritualis ianus) e que abre acesso aos demais sacramentos.

\section{Que nome recebe o primeiro sacramento da iniciação?}

Recebe em primeiro lugar o nome de Batismo por causa do rito central com o qual é celebrado: batizar significa "imergir" na água. Quem é batizado é imerso na morte de Cristo e ressurge com ele como "criatura nova" (2 Cor 5, 17). É chamado também de "banho da regeneração e renovação do Espírito Santo" (Tt 3,5) e de "iluminação" porque o batizado se torna "filho da luz" (Ef 5,8-9) (BENTO XVI, 2005, p. 89).

Dentro da ideologia católica, por meio da administração do sacramento do Batismo, que é necessário à salvação eterna, os fiéis são perdoados de seu pecado original e tornam-se 
participantes da vida trinitária, mediante a graça santificante, além de serem incorporados à Cristo e à sua Igreja, tornando-se, também, participantes de sua missão apostólica.

Por conseguinte, a instituição do sacramento da Crisma, ao imprimir na alma do cristão um caráter indelével, produz o crescimento da fé batismal e lhe confere força para testemunhar a fé cristã e resistir à tentação pelo pecado.

Tomemos um excerto do artigo referente ao sacramento da Confirmação:

\section{Qual é o rito essencial da Confirmação?}

O rito essencial da Confirmação é a unção com o sagrado crisma (óleo misturado com bálsamo, consagrado pelo Bispo), que se faz com a imposição da mão por parte do ministro que pronuncia as palavras sacramentais próprias do rito. No Ocidente, essa unção é feita na fronte do batizado com as palavras: "Recebe por este sinal o dom do Espírito Santo". Nas Igrejas Orientais de rito bizantino, a unção é feia também em outras partes do corpo, com a fórmula: "Selo do dom que é o Espírito Santo" (BENTO XVI: 2005, p. 92).

\section{Qual é o efeito da Confirmação?}

O efeito da confirmação é a especial efusão do Espírito Santo, como a de Pentecostes. Essa efusão imprime na alma um caráter indelével e produz um crescimento da graça batismal: enraiza mais profundamente na filiação divina; une mais solidamente a Cristo e a sua Igreja; aumenta na alma os dons do Espírito Santo; dá força especial para testemunhar a fé cristã (BENTO XVI, 2005, p. 92).

Dentro da ideologia católica, a celebração eucarística é “fonte e ápice de toda a vida cristã” (BENTO XVI, 2005, p. 93).

\section{O que é a Eucaristia?}

É o próprio sacrifício do Corpo e do Sangue do Senhor Jesus, que ele instituiu para perpetuar pelos séculos, até seu retorno, o sacrifício da cruz, confiando assim à sua Igreja o memorial de sua Morte e Ressurreição. É o sinal da unidade, o vínculo da caridade, o banquete pascal, no qual se recebe Cristo, a alma é coberta de graça e é dado o penhor da vida eterna. 132213231409 (BENTO XVI, 2005, p. 93).

A comunhão eucarística realiza-se no banquete pascal, pela qual Cristo dá o seu Corpo e o seu Sangue, por meio da transubstanciação das espécies eucarísticas do pão e do vinho, 
oferecidas como alimento e bebida, unindo-se aos fiéis no seu sacrifício (cf. BENTO XVI, 2005, p. 92). A administração da comunhão eucarística confere ao fiel os seguintes frutos $\left(\mathrm{O}_{\mathrm{v}}\right)$ : a) aumento da união com Cristo e com a Igreja; b) conservação e renovação da vida de graça recebida no Batismo e na Crisma; c) crescimento do amor ao próximo; d) fortificação na caridade; e) anulação dos pecados venais; f) preservação de futuros pecados mortais.

Os sacramentos da Penitência, da Reconciliação e da Unção dos Enfermos realizam a conversão dos batizados que se afastaram de Cristo pelo pecado.

Tomemos, inicialmente, o sacramento da Penitência e da Reconciliação.

297. Por que existe um sacramento da Reconciliação após o Batismo?

Uma vez que a vida nova na graça, recebida no Batismo, não suprimiu a fraqueza da natureza humana nem a inclinação do pecado (ou seja, a concupiscência), Cristo instituiu esse sacramento para a conversão dos batizados que se afastaram dele pelo pecado (BENTO XVI, 2005, p. 98).

No sacramento da Penitência ou Reconciliação, o sujeito realiza a performance representada pelos atos do penitente, exerce o cumprimento de determinados atos de penitência impostos pelo confessor para reparar o dano causado pelo pecado, aceita o contrato proposto de não pecar mais e recupera, portanto, o $\mathrm{O}_{\mathrm{v}}$ "graça divina", mediante o $\mathrm{PN}$ de doação de competência com a absolvição do sacerdote. O PN de doação de competência confere ao destinatário-sujeito os seguintes efeitos: a) reconciliação com Deus, e, por conseguinte, o perdão dos pecados; b) a reconciliação com a Igreja; c) remissão da pena eterna merecida pelos pecados mortais; d) remissão das penas temporais que são conseqüência do pecado; e) paz e serenidade de consciência; f) consolação do espírito; g) crescimento das forças espirituais para o combate cristão.

No sacramento da unção dos enfermos, o destinatário-sujeito, acometido por enfermidade ou em perigo de morte por doença ou velhice, recebe o $\mathrm{O}_{\mathrm{v}}$ "graça divina" por meio do PN de uso administrado pelo sacerdote pela unção com óleo sobre a fronte e as mãos 
do doente, acompanhada pela oração do sacerdote. Por meio da recepção do sacramento da unção dos enfermos é conferida ao sujeito: "uma graça particular que une mais particularmente o doente à Paixão de Cristo, para o seu bem e o de toda a Igreja, dando-lhe conforto, paz, coragem e até o perdão dos pecados, se o doente não pôde confessar-se" (BENTO XVI, 2005, p. 102). A administração desse sacramento, dentro da ideologia católica, pode até mesmo restabelecer a saúde do enfermo, mas em todo caso, sua administração “prepara o doente para a passagem à Casa do Pai” (BENTO XVI, 2005, p. 102).

Dentro da ideologia católica também, os sacramentos a serviço da comunhão e da missão: “a Ordem e o Matrimônio, conferem uma graça especial para uma missão particular na Igreja a serviço da edificação do povo de Deus. Eles contribuem em particular para a comunhão eclesial e para a salvação dos outros” (BENTO XVI, 2005, p. 103).

Tomemos, agora, o sacramento da Ordem. O destinador-manipulador, mediante a administração do sacramento da Ordem, consagra aqueles que o recebem, com a ordenação sagrada, para serem, "em nome de Cristo, pela palavra e pela graça de Deus, os pastores da Igreja" (JOÃO PAULO II, 2000, p. 420). O sacramento da Ordem compõe-se de três graus: o diaconato, o presbiterado e o episcopado.

\section{Por que se chama sacramento da Ordem?}

Ordem indica um corpo eclesial de que se passa a fazer parte mediante uma especial consagração (Ordenação), a qual, por um particular dom do Espírito Santo, permite exercer um sagrado poder em nome e com autoridade de Cristo a serviço do Povo de Deus (BENTO XVI, 2005, p. 103).

Por fim, a administração do sacramento do Matrimônio confere ao homem e à mulher o $\mathrm{O}_{\mathrm{v}}$ "graça divina", para que ambos possam realizar a união de suas vidas, segundo o originário desígnio divino, tendo o poder e a força necessários para enfrentar as ameaças da discórdia e infidelidade que possam abalar essa união. A administração desse sacramento, dentro da ideologia católica, “confere aos esposos a graça necessária para atingir a santidade 
na vida conjugal e para o acolhimento responsável dos filhos e a educação deles" (BENTO XVI, 2005, p. 108).

\section{Para que fins Deus instituiu o Matrimônio?}

A união matrimonial do homem e da mulher, fundada e estruturada com leis próprias pelo Criador, por sua natureza está ordenada à comunhão e ao bem dos cônjuges e à geração e educação dos filhos. A união matrimonial, segundo o originário desígnio divino, é indissolúvel, como afirma Jesus Cristo: "Não separe, pois, o homem o que Deus uniu" (Mc 10, 9) (BENTO XVI, 2005, p. 106).

Após examinar as concretizações textuais, mediante as quais verificamos como se desenvolve no enunciado a transmissão do saber a respeito do mistério sacramental, voltemos nossa atenção ao nível discursivo.

Examinemos as estruturas discursivas assumidas pelo sujeito da enunciação, no que diz respeito ao discurso-enunciado, com as escolhas das categorias de pessoa, tempo e espaço e às relações argumentativas estabelecidas entre enunciador e enunciatário.

O texto se caracteriza pela enunciação enunciada. Marcas textuais remetem à instância da enunciação.

Primeiramente, analisaremos a categoria de pessoa operacionalizada por esse discurso.

Tomemos o seguinte trecho:

\section{CAPÍTULO PRIMEIRO \\ Os sacramentos da iniciação cristã}

\section{Como se realiza a iniciação cristã?}

Ela se realiza mediante os sacramentos que estabelecem os fundamentos da vida cristã: os fiéis, renascidos no Batismo, são fortalecidos pela Confirmação e são nutridos pela Eucaristia. 12121275

O SACRAMENTO DO BATISMO

252. Que nomes recebe o primeiro sacramento da iniciação?

Recebe em primeiro lugar o nome de Batismo por causa do rito central com o qual é celebrado: batizar significa "imergir" na água. Quem é batizado é imerso na morte de Cristo e ressurge com ele como "criatura nova" (2 Cor 5, 17). É chamado também de "banho da regeneração e renovação do Espírito Santo" (Tt 3,5) e de "iluminação" porque o batizado se torna "filho da luz" (Ef 5,8-9) 1213-1216 1276-1277 


\section{Como é prefigurado o Batismo na Antiga Aliança?}

$\mathrm{Na}$ antiga Aliança encontram-se várias prefigurações do Batismo: a água, fonte de vida e de morte; a arca de Noé, que salva por meio da água; a passagem do Mar Vermelho, que liberta Israel da escravidão egípcia; a travessia do Jordão, que introduz Israel na terra prometida, imagem da vida eterna. 1217-1222 (BENTO XVI, 2005, p. 89).

O narrador, implícito ao enunciado, delega voz aos actantes do enunciado (narrador e narratário-leitor), por meio de uma debreagem enunciativa de primeiro grau. A utilização desse recurso permite construir um efeito de realidade. Esse efeito configura-se pela instauração do simulacro de uma cena enunciativa de sala de aula, obtido mediante a estruturação do texto em perguntas e respostas (perguntas retóricas). A utilização desse simulacro tem por objetivo, como o discurso mesmo enuncia, "propor um diálogo ideal entre o mestre e o discípulo mediante uma seqüência instigante de perguntas que envolvem o leitor, convidando-o a prosseguir na descoberta dos aspectos sempre novos da verdade sobre a fé" (BENTO XVI, 2005, p. 15).

Desse modo, verificamos a instauração da dimensão cognitiva do discurso com o estabelecimento de um simulacro de transmissão do saber a respeito da comunicação do mistério sacramental.

A categoria temporal, utilizada por esse discurso, remete ao presente omnitemporal ou gnômico, tempo verbal característico dos discursos de divulgação religiosa, pautados pela exposição de verdades eternas.

O simulacro da cena enunciativa de sala de aula, com a proposição de um diálogo ideal entre o mestre (catequista) e seu discípulo (catecúmeno), institui a presença do espaço do aqui, representação direta da enunciação. O enunciatário só adquire o saber a respeito dos mistérios sacramentais, progressivamente, ao longo do conteúdo dos artigos dispostos em perguntas e respostas. 
No que diz respeito às estratégias argumentativas empregadas para fazer-parecer verdadeiro o enunciado e obter a adesão do enunciatário, constatamos a utilização dos seguintes procedimentos: a) utilização da estrutura de perguntas e respostas; b) entrelaçamento diagramático e discursivo (temas e figuras) desenvolvidos no Catecismo de Roma; c) referências bíblicas como argumento de autoridade.

As coerções genéricas fazem o Compêndio apresentar estrita dependência com o Catecismo de Roma. A remissão constante aos parágrafos em que os mesmos tópicos estão desenvolvidos no Catecismo de Roma tem por função corroborar a autoridade do Compêndio como instrumento catequético.

\section{Quem é o ministro da Confirmação?}

O ministro originário é o bispo. Manifesta-se assim a ligação do crismado com a Igreja na sua dimensão apostólica. Quando é o presbítero que confere esse sacramento - como acontece ordinariamente no Oriente e em casos particulares no Ocidente, a ligação com o bispo e com a Igreja é expressa pelo presbítero, colaborador do bispo, e pelo sagrado crisma, consagrado pelo próprio bispo. 1312-1314 (BENTO XVI, 2005, p. 93).

Assim, observamos que os tópicos (1312-1314), remetem aos parágrafos desenvolvidos no Catecismo.

As referências bíblicas permeiam as questões. $\mathrm{O}$ procedimento argumentativo da citação da autoridade da Bíblia (constantemente invocada) é utilizado a fim de assegurar a veracidade da ação sacramental no desígnio divino como proveniente das Sagradas Escrituras.

A autoridade da Bíblia é invocada por meio dos seguintes procedimentos intertextuais: a) citação de autoridade; b) alusão.

a) citação de autoridade: 


\section{Quando foi instituído esse sacramento?}

O Senhor ressuscitado instituiu esse sacramento quando, na noite de Páscoa, apareceu a seus Apóstolos e lhes disse: "Recebei o Espírito Santo. A quem perdoardes os pecados serão perdoados; a quem os retiverdes, serão retidos" (Jo 20, 22-23) (BENTO XVI, 2005, p. 98) (grifo nosso).

b) alusão:

\section{Como é prefigurado o Batismo na Antiga Aliança?}

$\mathrm{Na}$ Antiga Aliança encontram-se várias prefigurações do Batismo: a água, fonte de vida e de morte; $\underline{a}$ arca de Noé, que salva por meio da água; $\underline{a}$ passagem do Mar vermelho, que liberta Israel da escravidão egípcia; $\underline{a}$ travessia do Rio Jordão, que introduz Israel na terra prometida, imagem da vida eterna (BENTO XVI, 2005, p. 89) (grifo nosso).

O Compêndio, como resumo do conteúdo do Catecismo de Roma, apresenta como configuração temática a exposição do conteúdo da fé, da moral, da prática cristã e da defesa da vida divina e da Santa Igreja.

O sujeito da enunciação, tendo por objetivo garantir a coerência semântica do discurso catequético, realiza a instauração de temas e figuras como espelhamento do texto fonte. Desse modo, os valores assumidos pelo sujeito da narrativa, ao longo da seqüência de PNs de uso, determinados pela administração de cada sacramento, são disseminados em percursos temáticos que se figurativizam graças à ação do sujeito da enunciação.

Vejamos como a segunda parte da seção II do Compêndio, pautada pela temática da celebração e comunicação da liturgia sacramental da Igreja Católica, apresenta, a partir da comunicação do $\mathrm{O}_{\mathrm{v}}$ "graça divina", a instauração dos seguintes percursos temáticos:

a) Iniciação à vida cristã (sacramentos da iniciação cristã).

\section{Como se realiza a iniciação cristã?}

Ela se realiza mediante os sacramentos que estabelecem os fundamentos da vida cristã: os fiéis, renascidos no Batismo, são fortalecidos pela Confirmação e são nutridos pela Eucaristia (BENTO XVI, 2005, p. 89). 
b) Purificação do pecado original (Batismo).

\title{
252. Que nomes recebe o primeiro sacramento da iniciação?
}

Recebe em primeiro lugar o nome de Batismo por causa do rito central com o qual é celebrado: batizar significa "imergir" na água. Quem é batizado é imerso na morte de Cristo e ressurge com ele como "criatura nova" (2 Cor 5, 17). É chamado também de "banho da regeneração e renovação do Espírito Santo" (Tt 3,5) e de "iluminação" porque o batizado se torna "filho da luz" (Ef 5,8-9) (BENTO XVI, 2005, p. 89).

c) Fortalecimento da graça batismal (Confirmação).

266. Porque se chama Crisma ou Confirmação?

Chama-se Crisma (nas Igrejas Orientais: Crismação com o Santo Myron), por causa do seu rito essencial, que é a unção. Chama-se Confirmação, porque confirma e consolida a graça batismal (BENTO XVI, 2005, p. 92).

d) Comunhão com Cristo e a sua Igreja (Eucaristia).

\section{O que representa a Eucaristia na vida da Igreja?}

É a fonte e ápice de toda a vida cristã. Na Eucaristia, atingem o seu clímax a ação santificante de Deus para conosco e o nosso culto para com ele. Ela encerra todo o bem espiritual da Igreja: o mesmo Cristo, nossa Páscoa. A comunhão da vida divina e a unidade do Povo de Deus são expressas e realizadas na Eucaristia. Mediante a celebração eucarística, já nos unimos à liturgia do Céu e antecipamos a vida eterna (BENTO XVI, 2005, p. 94).

e) Salvação do pecado (sacramentos da cura).

\begin{abstract}
295. Porque Cristo instituiu os sacramentos da Penitência e da Unção dos Enfermos?

Cristo, médico da alma e do corpo, os instituiu porque a vida nova, que nos foi dada por ele nos sacramentos da iniciação cristã, pode ser enfraquecida e até perdida por causa do pecado. Por isso, Cristo quis que a Igreja continuasse a sua obra de cura e de salvação mediante esses dois sacramentos (BENTO XVI, 2005, p. 98).
\end{abstract}

f) Conversão dos batizados que se afastaram da união de Cristo pela inclinação ao pecado (sacramento da Penitência e da Reconciliação). 
297. Porque existe um sacramento da Reconciliação após o Batismo?

Uma vez que a vida nova na graça, recebida no Batismo, não suprimiu a

fraqueza da natureza humana nem a inclinação ao pecado (ou seja, a concupiscência), Cristo instituiu esse sacramento para a conversão dos batizados que se afastaram dele pelo pecado (BENTO XVI, 2005, p. 98).

g) Preparação à passagem para a vida eterna (Unção dos Enfermos).

\section{Quais são os efeitos desse sacramento?}

Ele confere uma graça particular, que une mais intimamente o doente à paixão de Cristo, para o seu bem e o de toda a Igreja, dando-lhe conforto, paz, coragem e até o perdão dos pecados, se o doente não pôde confessar-se. Esse sacramento permite às vezes, se Deus o quiser, até a recuperação da saúde física. Em todo caso, essa Unção prepara o doente para a passagem à casa do Pai (BENTO XVI, 2005, p. 102).

h) Serviço de comunhão pastoral, do exercício missionário e da edificação do Povo de Deus

(sacramentos a serviço da comunhão e da missão).

321. Quais são os sacramentos a serviço da comunhão e da missão?

Dois sacramentos, a Ordem e o Matrimônio, conferem uma graça especial para uma missão particular na Igreja a serviço da edificação do povo de Deus. Eles contribuem em particular para a comunhão eclesial e para a salvação dos outros (BENTO XVI, 2005, p. 103).

i) Exercício da missão apostólica (sacramento da Ordem).

322. O que é o sacramento da Ordem?

É o sacramento graças ao qual a missão confiada por Cristo aos seus Apóstolos continua a ser exercida na Igreja, até o final dos tempos (BENTO XVI, 2005, p. 103).

j) União divina e da aliança matrimonial (Sacramento do Matrimônio).

338. Para que fins Deus instituiu o Matrimônio?

A união matrimonial do homem e da mulher, fundada e estruturada com leis próprias pelo Criador, por sua natureza está ordenada à comunhão e ao bem dos cônjuges e à geração e educação dos filhos. A união matrimonial, 
segundo o originário desígnio divino, é indissolúvel, como afirma Jesus Cristo: "Não separe, pois, o homem o que Deus uniu" (Mc 10,9) (BENTO XVI, 2005, p. 106).

k) Pecados gravemente contrários ao sacramento do Matrimônio.

\section{Quais são os pecados gravemente contrários ao sacramento do Matrimônio?}

São: o adultério; a poligamia, porquanto contradiz a igual dignidade entre o homem e a mulher, a unicidade e a exclusividade do amor conjugal; a rejeição da fecundidade, que priva a vida conjugal do dom dos filhos; e o divórcio, que transgride a indissolubilidade (BENTO XVI, 2005, p. 108).

Vejamos, portanto, como os percursos temáticos, correspondentes à comunicação da liturgia sacramental da Igreja Católica, recebem o investimento figurativo condizente com o sistema de restrições do catolicismo.

A figurativização, tendo por objetivo aumentar a ilusão referencial, ou seja, o efeito de sentido de realidade, ocorre no enunciado por meio da instauração dos ritos, dos sinais, das palavras e das ações efetuadas pelos ministros sacramentais que levam cada sacramento à consumação, ou por meio de alusões às Sagradas Escrituras. Transcreveremos os enunciados, destacando as figuras.

a) Iniciação à vida cristã (sacramentos da iniciação cristã):

Os fiéis, renascidos no Batismo, são fortalecidos pela Confirmação e são nutridos pela Eucaristia (BENTO XVI, 2005, p. 89). (grifo nosso)

b) Purificação do pecado original (Batismo):

Quem é batizado é imerso na morte de Cristo e ressurge com ele como "criatura nova" (2 Cor 5,17). É chamado também de "banho da regeneração e renovação do espírito Santo" (Tt 3,5) e de "iluminação" porque o batizado se torna "filho da luz" (Ef 5,8-19) (BENTO XVI, 2005, p. 89). (grifo nosso) 
$\mathrm{Na}$ antiga Aliança encontram-se várias prefigurações do Batismo: a água, fonte de vida e de morte; a arca de Noé, que salva por meio da água; a passagem do Mar Vermelho, que liberta Israel da escravidão egípcia; a travessia do Jordão, que introduz Israel na terra prometida, imagem da vida eterna (BENTO XVI, 2005, p. 89). (grifo nosso)

$\underline{\text { Jesus Cristo, o qual, no início da sua vida pública, se faz batizar por João }}$

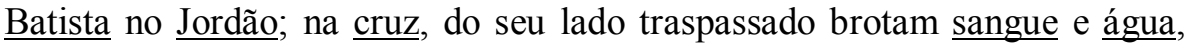
sinais do Batismo e da Eucaristia, e depois de sua Ressurreição confia aos Apóstolos esta missão: "Ide, pois, fazer discípulos entre todas as nações, e batizai-os em nome do Pai, do Filho e do Espírito Santo" (Mt 28, 19) (BENTO XVI, 2005, p. 90). (grifo nosso)

O batizado pertence para sempre a Cristo: é marcado, com efeito, com o selo indelével de Cristo (caráter) (BENTO XVI, 2005, p. 91). (grifo nosso)

c) Fortalecimento da graça batismal (Confirmação):

$\mathrm{Na}$ Antiga Aliança, os profetas anunciaram a comunicação do Espírito do Senhor ao Messias esperado e a todo o povo messiânico. Toda a vida e a missão de Jesus se desenvolvem numa total comunhão com o Espírito Santo. Os Apóstolos recebem o Espírito Santo no Pentecostes e anunciam "as maravilhas de Deus" (At 2, 11). Comunicam aos neobatizados, mediante a imposição das mãos, o dom do mesmo Espírito. Ao longo dos séculos, A Igreja continuou a viver do Espírito e a comunicá-lo a seus filhos (BENTO XVI, 2005, p. 92). (grifo nosso)

Chama-se Crisma (nas Igrejas Orientais: Crismação com o Santo Myron), por causa do seu rito essencial, que é a unção. Chama-se Confirmação, porque confirma e consolida a graça batismal (BENTO XVI, 2005, p. 92). (grifo nosso)

O efeito da Confirmação é a especial efusão do Espírito Santo, como a de Pentecostes. Essa efusão imprime na alma um caráter indelével e produz um crescimento da graça batismal: enraíza mais profundamente na filiação divina; une mais solidamente a Cristo e a sua Igreja; aumenta na alma os dons do Espírito Santo; dá força especial para testemunhar a fé cristã (BENTO XVI, 2005, p. 92). (grifo nosso)

d) Comunhão com Cristo e a sua Igreja (Eucaristia):

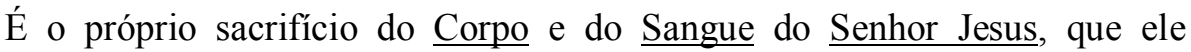
instituiu para perpetuar pelos séculos, até seu retorno, o sacrifício da cruz, confiando assim à sua Igreja o memorial de sua Morte e Ressurreição. É o sinal da unidade, o vínculo da caridade, o banquete pascal, no qual se recebe Cristo, a alma é coberta de graça e é dado o penhor da vida eterna (BENTO XVI, 2005, p. 93). (grifo nosso) 
Depois de ter reunido os seus Apóstolos no Cenáculo, Jesus tomou nas mãos o pão, partiu-o e o deu a eles, dizendo: "Tomai todos e comei: isto é o meu corpo que será entregue por vós". Depois tomou nas suas mãos o cálice do vinho e lhes disse: "Tomai todos e bebei: este é o cálice do meu sangue, o sangue da nova e eterna aliança, que será derramado por vós e por todos para a remissão dos pecados. Fazei isto em memória de mim" (BENTO XVI, 2005, p. 93). (grifo nosso)

A insondável riqueza desse sacramento se exprime em diversos nomes que evocam seus aspectos particulares. Os mais comuns são: Eucaristia, Santa Missa, Ceia do Senhor, Fração do pão, Celebração eucarística, Memorial da paixão, da morte e da ressurreição do Senhor, Santo Sacrifício, Santa e Divina Liturgia, Santos Mistérios, Santíssimo Sacramento do altar, Santa Comunhão (BENTO XVI, 2005, p. 94). (grifo nosso)

Na Antiga Aliança, a Eucaristia é prenunciada, sobretudo, na ceia pascal anual, celebrada todo ano pelos hebreus com os pães ázimos como lembrança da imprevista e libertadora saída do Egito. Jesus a anuncia em seu ensinamento e a institui celebrando com os seus Apóstolos a Última Ceia durante um banquete pascal (BENTO XVI, 2005, p. 94). (grifo nosso)

Desdobra-se em dois grandes momentos, que forma um só ato de culto: a liturgia da Palavra, que compreende a proclamação e a escuta da Palavra de Deus; a liturgia eucarística, que compreende a apresentação do pão e do vinho, a oração ou anáfora que contém as palavras da consagração, e a comunhão (BENTO XVI, 2005, p. 94). (grifo nosso).

São o pão de trigo e o vinho da videira (BENTO XVI, 2005, p. 94). (grifo nosso)

Jesus está presente na Eucaristia de modo único e inseparável. Está presente, com efeito, de modo verdadeiro, real, substancial: com o seu Corpo e o seu $\underline{\text { Sangue, }}$ com a sua Alma e a sua Divindade. Nela está, portanto, presente de modo sacramental, ou seja, sob as espécies eucarísticas do pão e do vinho, Cristo todo inteiro: Deus e homem (BENTO XVI, 2005, p. 95). (grifo nosso)

Transubstanciação significa a conversão de toda a substância do pão na substância do Corpo de Cristo e de toda a substância do vinho na substância do seu Sangue (BENTO XVI, 2005, p. 95) (grifo nosso)

A Igreja, com efeito, conserva com a máxima diligência as Hóstias consagradas, leva-as aos enfermos e a outras pessoas impossibilitadas de participar da Santa Missa, apresenta-as à solene adoração dos fiéis, leva-as em procissão e convida à freqüente visita e adoração do Santíssimo Sacramento conservado no tabernáculo (BENTO XVI, 2005, p. 96). (grifo nosso)

A Eucaristia é o banquete pascal, porquanto Cristo, ao realizar sacramentalmente a sua Páscoa, nos dá o seu Corpo e o seu Sangue, oferecidos como alimento e bebida, e nos une a si e entre nós no seu sacrifício (BENTO XVI, 2005, p.96). (grifo nossos)

O_altar é o símbolo do próprio Cristo, presente como vítima sacrificial (altar-sacrifício da cruz) e como alimento celeste que se dá a nós (altar-mesa eucaristia) (BENTO XVI, 2005, p. 96). (grifo nosso) 
e) Salvação do pecado (sacramentos da cura):

\section{Porque Cristo instituiu os sacramentos da Penitência e da Unção dos enfermos?}

Cristo, médico da alma e do corpo, os instituiu porque a vida nova, que nos foi dada por ele nos sacramentos da iniciação cristã, pode ser enfraquecida e até perdida por causa do pecado. Por isso, Cristo quis que a Igreja continuasse a sua obra de cura e salvação mediante esses dois sacramentos (BENTO XVI, 2005, p. 98). (grifo nosso)

f) Conversão dos batizados que se afastaram da união de Cristo pela inclinação ao pecado (sacramento da Penitência e da Reconciliação):

A penitência se exprime de formas muito variadas, em particular com o jejum, a oração, a esmola. Essas e outras muitas formas de penitência podem ser praticadas na vida cotidiana do cristão, em particular no tempo da Quaresma e no dia penitencial da sexta-feira (BENTO XVI, 2005, p. 99). (grifo nosso)

\section{Quais são os atos do penitente?}

São: um diligente exame de consciência; a contrição (ou arrependimento), que é perfeita quando é motivada pelo amor para com Deus, imperfeita se fundada em outros motivos, e que inclui o propósito de não pecar mais; a confissão, que consiste na acusação dos pecados feita perante o sacerdote; a satisfação, ou seja, o cumprimento de certos atos de penitência que o confessor impõe ao penitente para reparar o dano causado pelo pecado (BENTO XVI, 2005, p. 99). (grifo nosso)

\section{O que são as indulgências?}

As indulgências são a remissão diante de Deus da pena temporal merecida pelos pecados, já perdoados quanto à culpa, que o fiel, em determinadas condições, adquire para si mesmo ou para os defuntos mediante o ministério da Igreja, a qual, como dispensadora da redenção, distribui os tesouros dos méritos de Cristo e dos Santos (BENTO XVI, 2005, p. 101). (grifo nosso)

g) Preparação à passagem para a vida eterna (Unção dos Enfermos):

No Antigo Testamento, o homem experimenta durante a doença o próprio limite e percebe ao mesmo tempo que a doença está ligada, de modo misterioso, ao pecado (BENTO XVI, 2005, p. 101). (grifo nosso)

A Igreja, tendo recebido do Senhor a ordem de curar os enfermos, compromete-se a cumpri-la com os cuidados para com os doentes, acompanhados de oração de intercessão (BENTO XVI, 2005, p. 102). (grifo nosso) 
A celebração desse sacramento consiste essencialmente na unção com o óleo, bento possivelmente pelo Bispo, sobre a fronte e sobre as mãos do doente (no rito romano, ou também em outra parte do corpo, em outros ritos), acompanhada pela oração do sacerdote, que implora a graça especial desse sacramento (BENTO XVI, 2005, p. 102). (grifo nosso)

\section{O que é viático?}

É a Eucaristia recebida por aqueles que estão por deixar esta vida e se preparam para a passagem para a vida eterna. Recebida no momento da passagem deste mundo para o Pai, a comunhão do Corpo e Sangue de Cristo morto e ressuscitado é semente de vida eterna e poder de ressurreição (BENTO XVI, 2005, p. 103). (grifo nosso)

h) Serviço de comunhão pastoral, do exercício missionário e da edificação do Povo de Deus (sacramentos a serviço da comunhão e da missão):

Dois sacramentos, a Ordem e o Matrimônio, conferem uma graça especial para uma missão particular na Igreja a serviço da edificação do povo de Deus. Eles contribuem em particular para a comunhão eclesial e para a salvação dos outros (BENTO XVI, 2005, p. 103). (grifo nosso)

i) Tema do exercício da missão apostólica (sacramento da Ordem):

Ordem indica um corpo eclesial de que se passa a fazer parte mediante uma especial consagração (Ordenação), a qual, por um particular dom do Espírito $\underline{\text { Santo, }}$ permite exercer um sagrado poder em nome e com a autoridade de Cristo a serviço do Povo de Deus (BENTO XVI, 2005, p. 103). (grifo nosso)

$\mathrm{Na}$ Antiga Aliança, são prefigurações desse sacramento o serviço dos Levitas, bem como o sacerdócio de Aarão e a instituição dos setenta "Anciãos" (Nm 11, 25) (BENTO XVI, 2005, p. 103) (grifo nosso)

A unção do Espírito marca o presbítero comum com um caráter espiritual indelével, configura-o a Cristo sacerdote e o torna capaz de agir no Nome de Cristo Cabeça. Sendo o cooperador da ordem episcopal ele é consagrado para pregar o Evangelho, para celebrar o culto divino, sobretudo a Eucaristia de que tira força o seu ministério, e para ser o pastor dos fiéis (BENTO XVI, 2005, p. 104). (grifo nosso)

Para cada um dos três graus, o sacramento da Ordem é conferido mediante a imposição das mãos sobre a cabeça do ordenando por parte do bispo, que pronuncia a solene oração consagradora. Com ela o Bispo invoca de Deus para o ordenando a especial efusão do Espírito Santo e dos seus dons, em vista do ministério (BENTO XVI, 2005, p. 105). (grifo nosso)

Para o episcopado é sempre exigido o celibato (BENTO XVI, 2005, p. 105). (grifo nosso) 
j) União divina e da aliança matrimonial (Sacramento do Matrimônio):

Deus, que é amor e criou o homem por amor, chamou-o a amar. Criando o homem e a mulher, chamou-os no Matrimônio a uma íntima comunhão de vida e de amor entre si, "assim, eles não são mais dois, mas uma só carne" (Mt 19,6) (BENTO XVI, 2005, p. 106). (grifo nosso)

A Aliança nupcial de Deus com Israel prepara e prefigura a Aliança nova realizada pelo Filho de Deus, Jesus Cristo, com a sua esposa, a Igreja (BENTO XVI, 2005, p. 107). (grifo nosso)

O consenso matrimonial é a vontade expressa por um homem e uma mulher de se doar mutuamente e definitivamente, com o objetivo de viver uma aliança de amor fiel e fecundo (BENTO XVI, 2005, p. 107-108). (grifo nosso)

k) Pecados gravemente contrários ao sacramento do Matrimônio:

347. Quais são os pecados gravemente contrários ao sacramento do Matrimônio?

São: o adultério, a poligamia, porquanto contradiz a igual dignidade entre o homem e a mulher, a unicidade e a exclusividade do amor conjugal; a rejeição da fecundidade, que priva a vida conjugal do dom dos filhos; e o divórcio, que transgride a indissolubilidade (BENTO XVI: 2006, p. 108). (grifo nosso) 
1.2 A Iconografia Cristã como Percepção Sacralizada: Análise do Tríptico dos Sete Sacramentos de Rogier Van Der Weyden

Examinemos a operacionalidade do conceito de semi-simbolismo, aplicando tal conceito ao estudo da pintura iconográfica cristã. Estabelecemos como recorte textual a análise do Tríptico dos Sete Sacramentos (1445-50) de Rogier Van Der Weyden, que ilustra a segunda seção da segunda parte do Compêndio do Catecismo da Igreja Católica: Os Sete Sacramentos da Igreja.

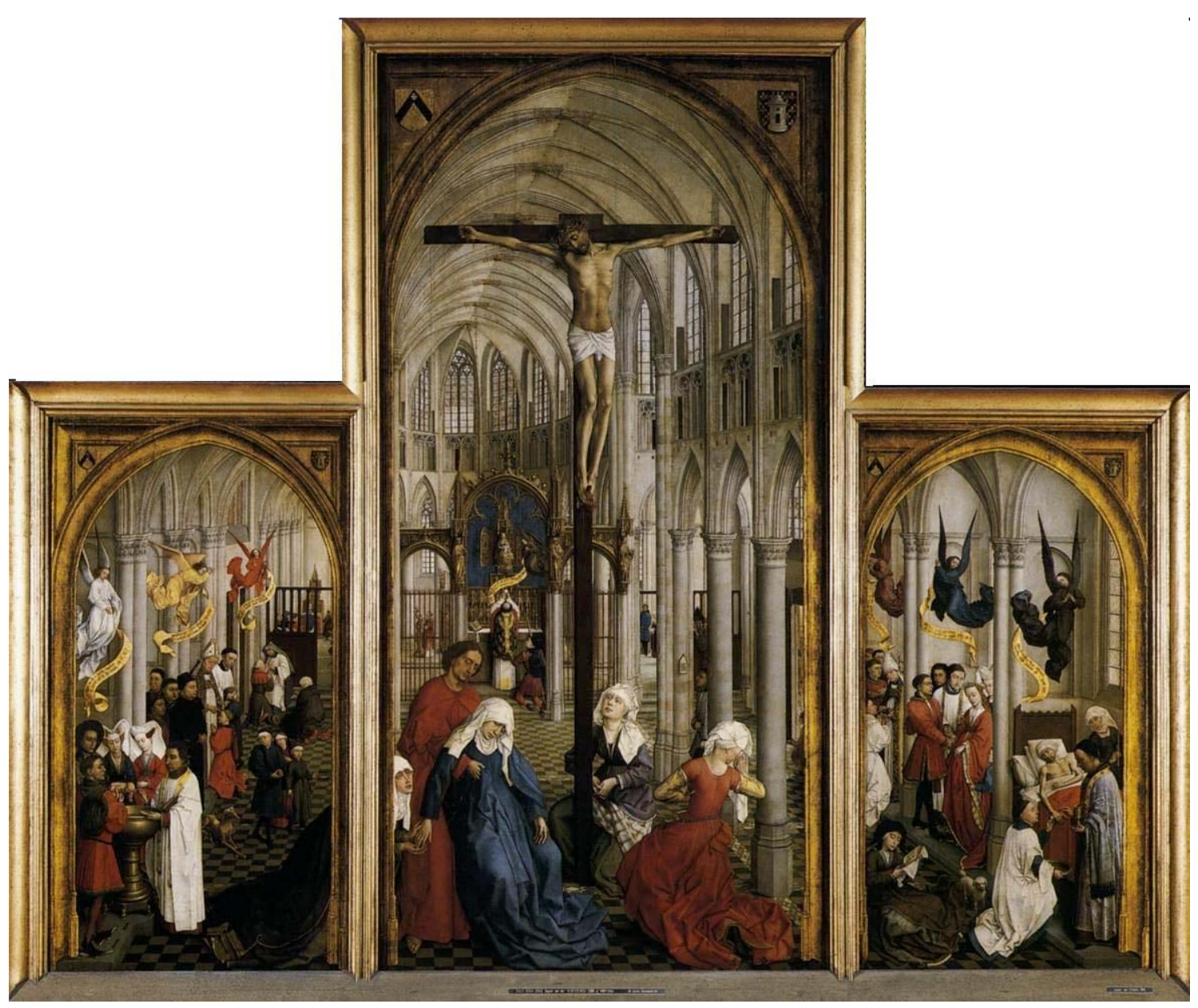

Ilustração 29 WEYDEN, Rogier Van Der. Tríptico dos sete sacramentos, Koninklijk Museum voor Schone Kunsten, Antuérpia. 
Ao adotarmos por princípio a isomorfia entre os dois planos da linguagem proposta por Hjelmslev (1965), atentaremos para as relações semi-simbólicas com a homologação entre categorias semânticas e plásticas.

Utilizaremos também a noção de ritmo, que será analisada na perspectiva da semiótica tensiva. Desse modo, descreveremos o sujeito da percepção inerente ao enunciado considerado, ou seja, o sujeito-observador que apreende o mundo segundo um ritmo e que, ao imprimir tal ritmo a seus discursos, contribui para a fundamentação do éthos.

O Tríptico dos Sete Sacramentos de Rogier Van Der Weyden apresenta como tema nuclear a celebração da liturgia "sacramental" da Igreja Católica.

Tal celebração sacramental, ao atingir todas as fases da vida de fé do cristão, desde seu nascimento até sua morte, permite estabelecer uma analogia entre as etapas da vida natural e da vida espiritual, como são concebidas pela cultura ocidental, de tendência cristã. Vida Natural: Nascimento $\rightarrow$ Crescimento $\rightarrow$ Alimento $\rightarrow$ Remédio $\rightarrow$ Comunidade $\rightarrow$ Casamento $\rightarrow$ Morte. Vida Espiritual: Batismo $\rightarrow$ Confirmação $\rightarrow$ Eucaristia $\rightarrow$ Penitência $\rightarrow$ Ordem $\rightarrow$ Matrimônio $\rightarrow$ Unção dos Enfermos. Desse modo, podemos recuperar a categoria semântica fundamental vida vs. morte como fundamento da organização mínima do texto. O percurso apresentado no enunciado nos confere a seguinte orientação: vida $\rightarrow$ não-vida $\rightarrow$ morte.

O catecismo define a necessidade dos sacramentos para que o sujeito possa participar da Igreja e se preparar para uma vivência não na Terra, mas no céu.

No que concerne ao Programa Narrativo (PN), "sintagma elementar da sintaxe narrativa", constituído de "um enunciado de fazer que rege um enunciado de estado" (BARROS, 2002, p. 31), observamos a transformação principal operacionalizada nesse discurso como a ação de um sujeito sobre outro, para que este último possa manter-se em conjunção com o objeto valor "graça divina".

Assim, o programa de base que rege o discurso é descrito como se segue: 
PN de base: $S_{1} \rightarrow S_{2} \cap O_{v}$

$\mathrm{S}_{1}=$ Jesus/Palavra Revelada; $\mathrm{S}_{2}=$ Ministro sacramental; $\mathrm{O}_{\mathrm{v}}=$ transmitir a "graça divina".

Desse modo, por meio de uma seqüência de PNs de uso, dados pela administração dos sete sacramentos, têm-se instaurado, no enunciado, programas de doação de competência pela recepção dos dons de Cristo. Os ministros, tidos como os legítimos responsáveis pela administração de cada sacramento, comunicam, por meio dos ritos, dos sinais, das palavras e das ações, os dons do Espírito Santo que levam cada sacramento à sua consumação. Observamos, no enunciado, a exposição da transformação de estados do sujeito cristão, que inicialmente disjunto do $\mathrm{O}_{\mathrm{v}}$ "graça divina", busca a sua conjunção. Essa conjunção manifestase por meio do estabelecimento da comunicação ritualística dos sacramentos.

Partimos das reflexões elaboradas por Floch (1985), concernentes à análise do plano de expressão das semióticas visuais (planas ou bidimensionais), por meio do reconhecimento de formantes figurativos e formantes plásticos.

O Tríptico dos Sete Sacramentos apresenta uma Igreja de arquitetura gótica, na qual são celebrados os sacramentos católicos.

Os ritos referentes a cada sacramento são figurativizados em conformidade com o enunciado verbal do Compêndio divulgador. Desse modo, a hipótese básica que fazemos a respeito dessa seção é a de que o enunciado verbal do Tríptico dos Sete Sacramentos remete, metonimicamente, à estrutura da parte considerada do Compêndio: os sete sacramentos da Igreja, no que diz respeito à comunicação sacramental ritualística.

Uma primeira segmentação do quadro, determinada a partir da oposição de relações entre elementos visuais, permite reconhecer a divisão do espaço representado. Por essa 
divisão notamos a articulação de três unidades discretas: uma parte esquerda, uma parte direita e uma parte central.

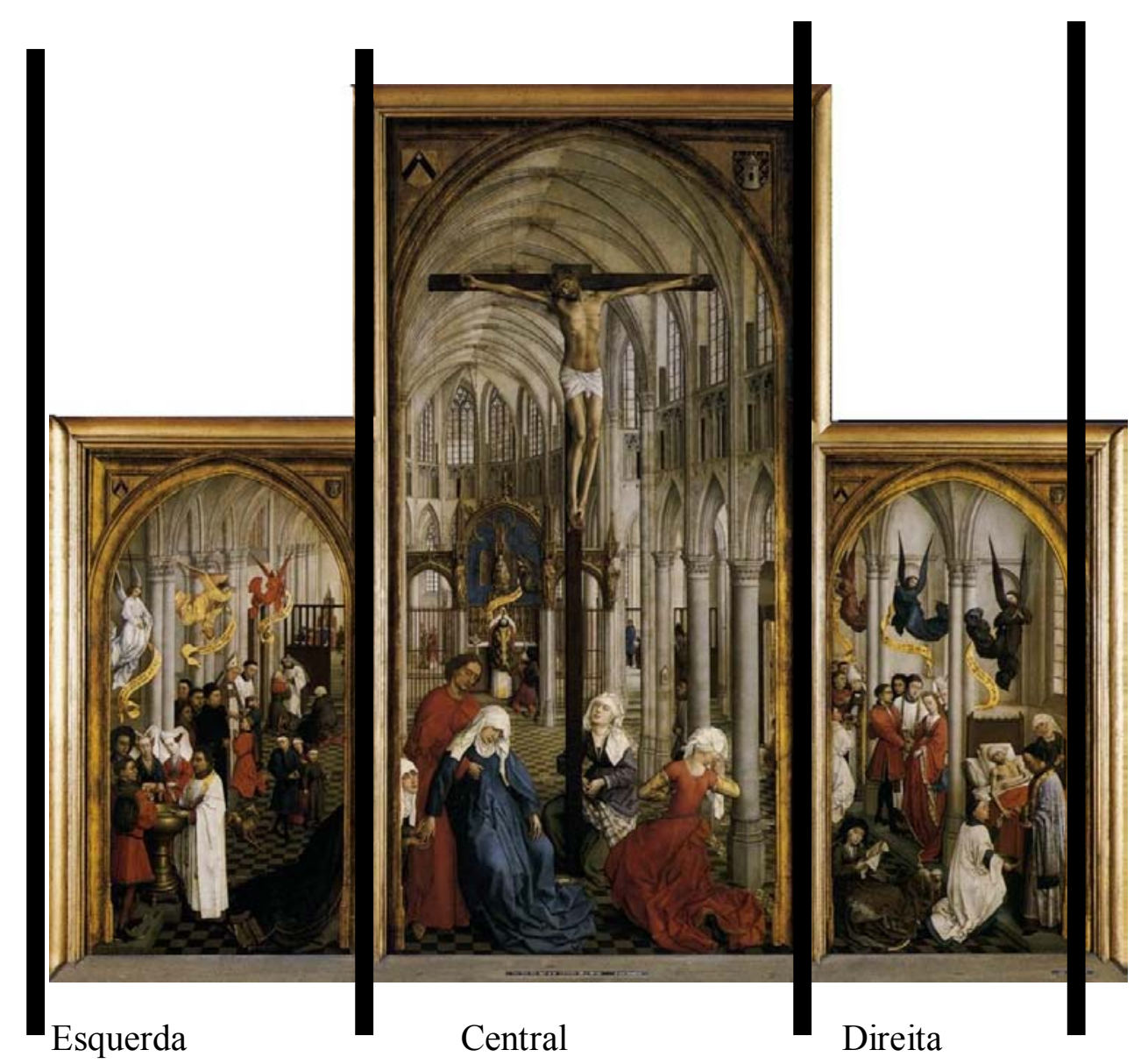

Ilustração 30 WEYDEN, Rogier Van Der. Tríptico dos sete sacramentos, Koninklijk Museum voor Schone Kunsten, Antuérpia.

No centro, ergue-se em primeiro plano: a cruz, que discursiviza o sacrifício de Cristo. Ao pé da cruz estão Maria (símbolo da Igreja), desfalecida e sustentada por João, e as mulheres devotas. Ao fundo um sacerdote celebrante eleva a hóstia após a consagração, a fim de demonstrar que o sacrifício da cruz é novamente atualizado durante a celebração eucarística sob as espécies do pão e do vinho. O sacrifício da missa, determinado como legítimo centro da fé católica, é de fundamental importância para o relacionamento do homem com Deus. Na missa é celebrado de modo sacramental o mistério da vida, morte e 
ressurreição de Cristo, ato de amor responsável pela transformação, conversão e cura daqueles que o recebem. Cada um dos sete sacramentos acompanhados por um anjo e uma bandeirola são concretizados em torno do grupo central da crucifixão. A importância do grupo central é indicada pela diferença de escala e proporção dos personagens do painel central. O painel central pertence ao mesmo plano que os demais. O padre, ao realizar a celebração eucarística encontra-se no mesmo nível da penitência, com a ressalva de que existe um degrau no altar. Podemos constatar que a cruz está em um nível superior ao cenário, em um degrau. Maria Madalena também aparece ajoelhada em cima de um degrau. A cruz está em um nível superior ao altar. Verificamos, portanto, que a cena da crucifixão de Cristo não faz parte do cenário. Ela foi inserida no painel central para retomar a atualização das espécies eucarísticas do pão e do vinho realizadas durante a celebração eucarística. Os personagens figurativizados possuem uma proporção maior do que os atores do enunciado dos painéis laterais. A importância da ação também é enfatizada pela maior expressividade presente nos rostos dos atores do enunciado.

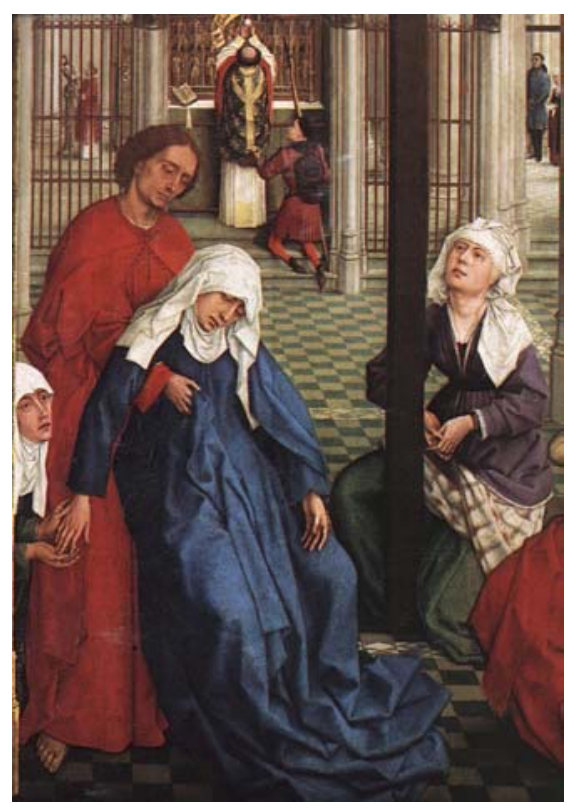

Ilustração 31WEYDEN, Rogier Van Der. Tríptico dos sete sacramentos, Koninklijk Museum voor Schone Kunsten, Antuérpia. (Detalhe do painel central). 
A identificação dos personagens retratados no painel central (mulheres devotas) pode ser reforçada por meio da remissão intertextual ao texto bíblico fundador. A descrição da cena da crucificação de Cristo pode ser encontrada nos evangelhos de Mateus, Marcos e João.

${ }_{55}$ Estavam ali muitas mulheres, olhando de longe. Haviam acompanhado Jesus desde a Galiléia, a servi-lo. ${ }_{56}$ Entre elas, Maria Madalena, Maria, mãe de Tiago e de José, e a mãe dos filhos de Zebedeu (Mt 27, 55-56) (BÍBLIA de Jerusalém, 2004, p. 1756) ${ }^{15}$.

As santas mulheres no Calvário - ${ }_{40} \mathrm{E}$ também estavam ali algumas mulheres, olhando de longe. Entre elas, Maria de Magdala, Maria, mãe de Tiago, o Menor, e de Joset, e Salomé (Mc 15, 40) (BÍBLIA de Jerusalém, 2004, p. 1784).

Jesus e sua mãe $-{ }_{25}$ Perto da cruz de Jesus, permaneciam de pé sua mãe, a irmã de sua mãe, Maria, mulher de Clopas, e Maria Madalena.26 Jesus, então, vendo sua mãe e, perto dela, o discípulo a quem amava, disse à sua mãe: "Mulher, eis teu filho!" ${ }_{27}$ Depois disse ao discípulo: "Eis tua mãe!” E a partir dessa hora, o discípulo a recebeu em sua casa (Jo 19, 25-27) (BÍBLIA de Jerusalém, 2004, p. 1891).

A ancoragem histórica com a representação da cena da crucifixão e morte de Jesus que, segundo o sistema de valores cristãos, propiciou a salvação da humanidade em relação ao pecado original, constitui por meio de um efeito de iconicidade, um recurso argumentativo que tem por objetivo fazer com que o enunciatário aceite os valores não comuns que o enunciador católico dispõe-se a partilhar.

A Paixão de Cristo é a fonte de todos os sacramentos da Igreja Católica. Do lado traspassado de Cristo brotam sangue e água: símbolos dos sacramentos da Igreja.

O golpe da lança - ${ }_{31}$ Como era a Preparação, os judeus, para que os corpos não ficassem na cruz durante o sábado - porque esse sábado era um grande dia! - pediram a Pilatos que lhes quebrassem as pernas e fossem retirados. ${ }_{32}$ Vieram, então, os soldados e quebraram as pernas do primeiro e depois do outro, que fora crucificado com ele. ${ }_{33}$ Chegando a Jesus e vendo-o já morto, não lhe quebraram as pernas, ${ }_{34}$ mas um dos soldados traspassou-lhe o lado com uma lança e imediatamente saiu sangue e água (Jo 19, 31-34) (BÍBLIA de Jerusalém, 2004, p. 1891).

\footnotetext{
${ }^{15}$ Todas as remissões ao discurso fundador bíblico, no que diz respeito ao discurso católico, serão pautadas pela utilização da BÍBLIA de Jerusalém. São Paulo: Paulus, 2004.
} 


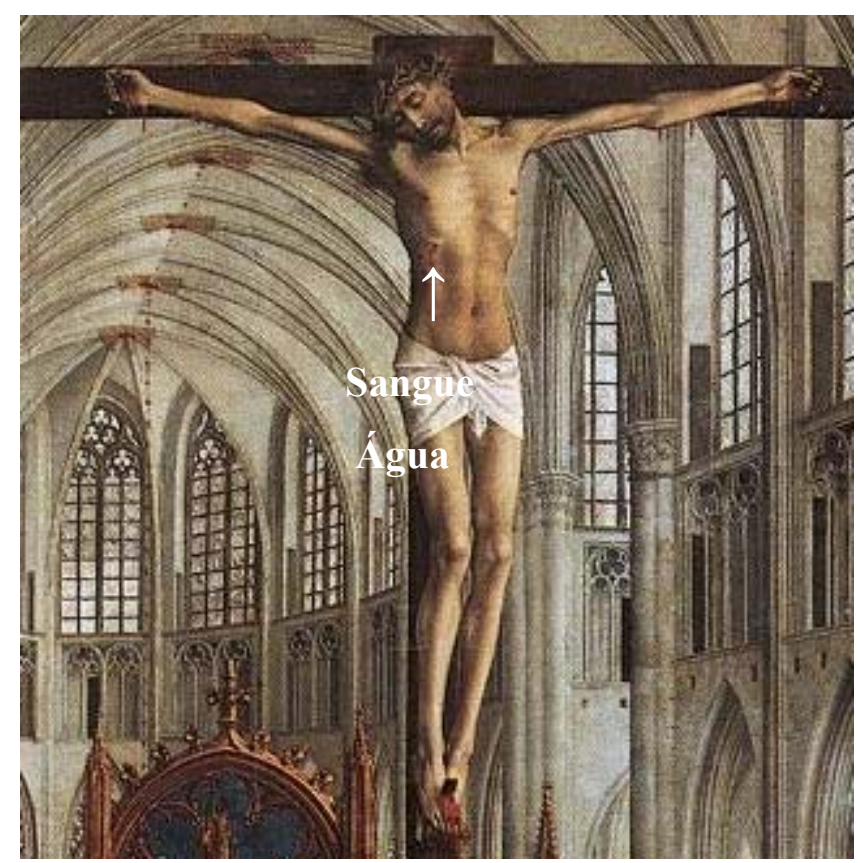

Ilustração 32 WEYDEN, Rogier Van Der. Tríptico dos sete sacramentos, Koninklijk Museum voor Schone Kunsten, Antuérpia. ( Detalhe do painel central).

A água é o símbolo do Batismo e o sangue se encontra na Eucaristia, o maior dos sacramentos católicos, tido como o próprio sacrifício do Corpo e do Sangue de Cristo. A motivação dos sacramentos é determinada por todo o processo da Paixão de Cristo.

Os mistérios da vida de Cristo são os fundamentos daquilo que agora, por meio dos ministros da Igreja, Cristo dispensa nos sacramentos, pois "aquilo que era visível em nosso Salvador passou para seus mistérios"

Os sacramentos são "forças que saem" do corpo de Cristo, sempre vivo e vivificante; são as ações do Espírito Santo operante no corpo de Cristo, que é a Igreja; são "as obras-primas de Deus" na Nova e Eterna Aliança (BENTO XVI, 2005, p. 315).

A Igreja Católica participa dos mistérios da vida de Cristo pela celebração do mistério sacramental. O Batismo recorda a Páscoa de Cristo. No Batismo o homem velho morre para que o homem novo possa ressurgir. Na Páscoa, Cristo ao ressuscitar, surge novamente para a vida, que é a vida eterna. Com a Crisma a Igreja celebra e participa do dom do Espírito Santo que fora enviado aos primeiros apóstolos no cenáculo. Na Eucaristia, a Igreja torna presente e atual o sacrifício que Cristo ofereceu na Cruz, para a remissão dos pecados. São reconhecidas nas espécies eucarísticas do pão e do vinho, o próprio Corpo e Sangue de Jesus oferecidos em 
sacrifício. Com o sacramento da Penitência ou Reconciliação, a mesma misericórdia e o perdão de Deus manifestados em Cristo são oferecidos em benefício dos fiéis que se afastaram de Cristo pela prática do pecado. $\mathrm{Na}$ cruz, Cristo redime todos os pecados de toda a humanidade. Realiza-se, portanto, o maior ato de amor de Deus para com os homens: entregar seu próprio filho para a remissão dos pecados e salvação do mundo. A Unção dos Enfermos dá continuidade à obra curativa e salvífica de Cristo. No mistério da Ordem, a Igreja celebra a continuação da missão confiada por Cristo aos seus Apóstolos, com o anúncio do Evangelho, pela santificação, pelo culto e pelo pastoreio do rebanho de Cristo. No Matrimônio, símbolo da comunhão de vida e de amor entre o homem e a mulher, a Igreja celebra a relação de amor entre Cristo e a Igreja, sua esposa, em prol de toda a humanidade.

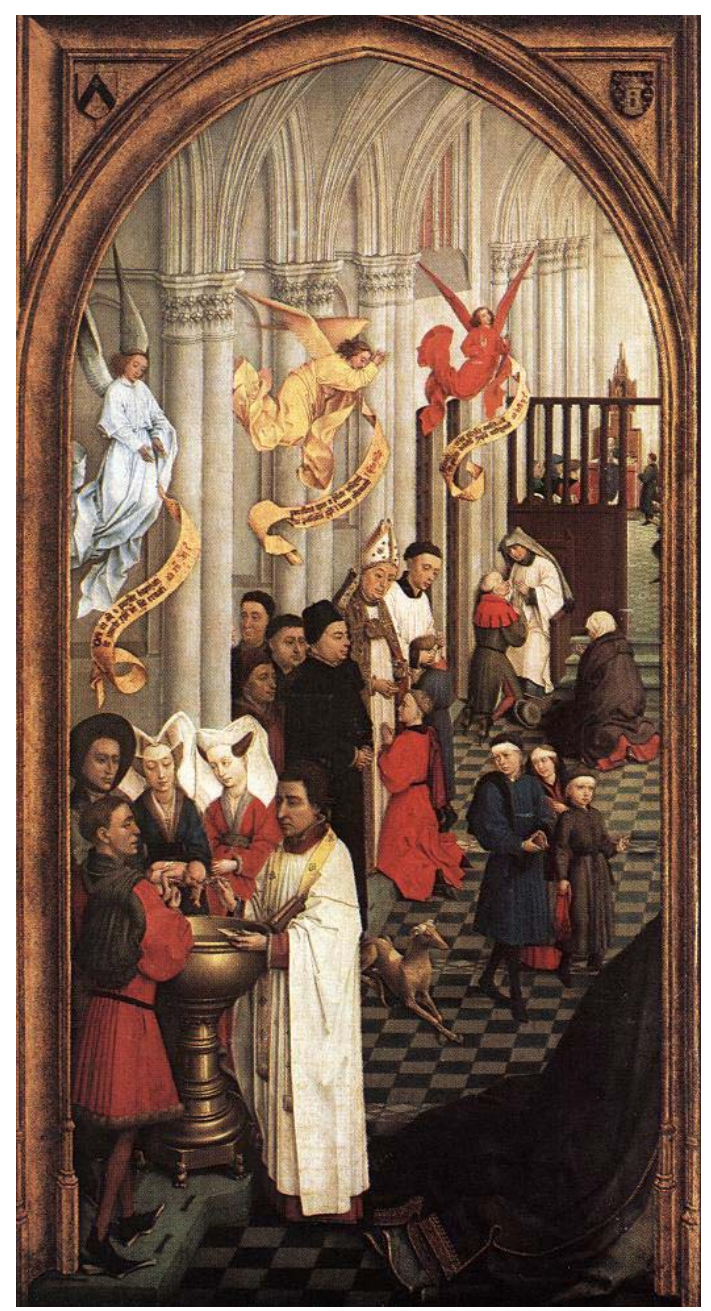

Ilustração 33 WEYDEN, Rogier Van Der. Tríptico dos sete sacramentos, Koninklijk Museum voor Schone Kunsten, Antuérpia. (Painel esquerdo). 
No retábulo da esquerda, o autor do quadro representa os sacramentos do Batismo, da Crisma e da Penitência, por meio dos ritos próprios a cada sacramento. O sacramento do Batismo é determinado pela isotopia figurativa da imersão na água por meio da celebração de seu rito essencial, que "consiste em imergir na água o candidato ou em derramar água sobre sua cabeça, enquanto é invocado o Nome do Pai, do Filho e do Espírito Santo" (BENTO XVI, 2005, p. 90). O sacramento da Crisma é ministrado por meio da figurativização do rito essencial da Confirmação que "é a unção com o sagrado crisma (óleo misturado com bálsamo, consagrado pelo bispo), que se faz com a imposição da mão por parte do ministro que pronuncia as palavras sacramentais próprias do rito" (BENTO XVI, 2005, p. 92). O sacramento da Penitência aparece figurativizado pela confissão, "que consiste na acusação dos pecados feita perante o sacerdote" (BENTO XVI, 2005, p. 99).

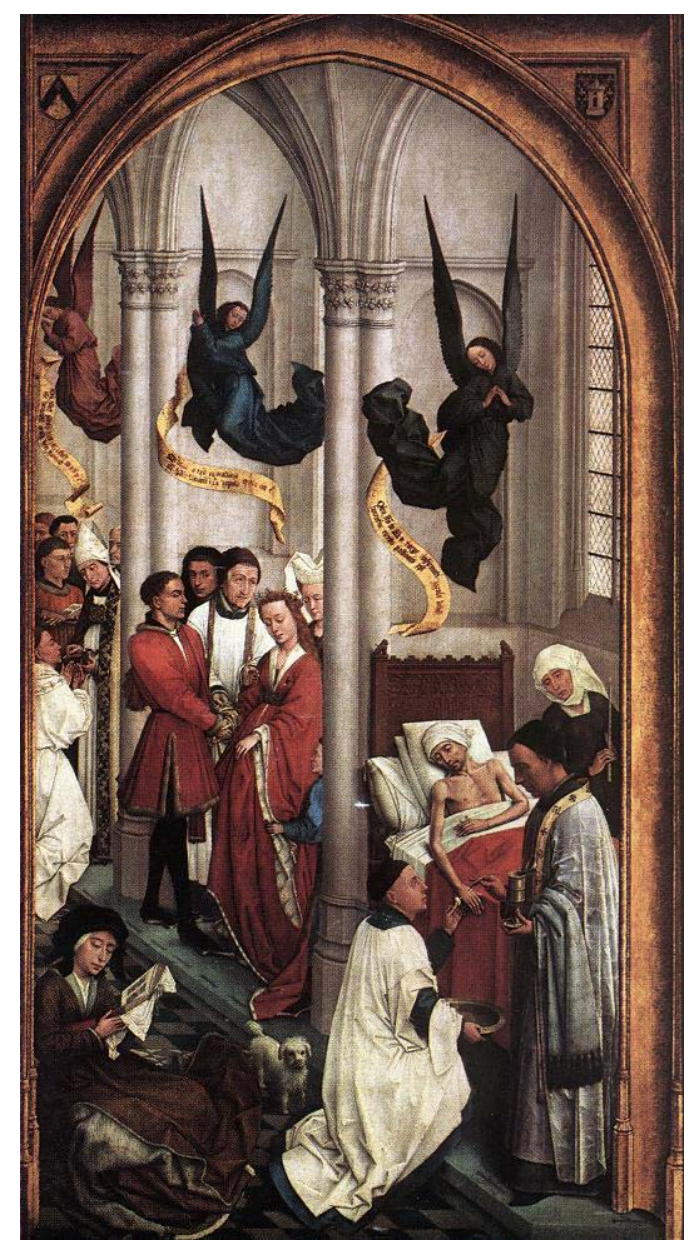

Ilustração 34 WEYDEN, Rogier Van Der. Tríptico dos sete sacramentos, Koninklijk Museum voor Schone Kunsten, Antuérpia. (Painel direito). 
Na prancha direita estão representados os sacramentos da Ordem, do Matrimônio e da Unção dos enfermos. O sacramento da Ordem é figurativizado pela “imposição das mãos sobre a cabeça do ordenado por parte do Bispo, que pronuncia a solene oração consagradora" (BENTO XVI, 2005, p. 105). O sacramento do Matrimônio é figurativizado pela celebração da aliança matrimonial entre um homem e uma mulher, efetuada na presença do sacerdote e de outras testemunhas. O sacramento da Unção dos Enfermos é figurativizado pela celebração sacramental efetuada por meio da unção com óleo sobre as frontes e sobre as mãos do doente em perigo de morte, acompanhada pela realização da oração do sacerdote, que confere a graça necessária para a passagem à Casa do Pai. Figurativiza-se também a presença da esposa do homem que recebe a extrema-unção, disposta ao lado da cama, com uma vela para ser inserida na mão do doente em seu leito de morte. A vela acesa possui o simbolismo de substituir diante de Deus a pessoa que a acende: Ela se consome, como se fosse um sacrifício oferecido a Deus. Uma vela acesa a Deus simboliza, portanto, a adoração e a entrega total de quem a acende ao Deus Todo Poderoso, Senhor e Criador de todos os seres.

Interessante notar também, no canto esquerdo desse painel, a representação de uma mulher com um livro.

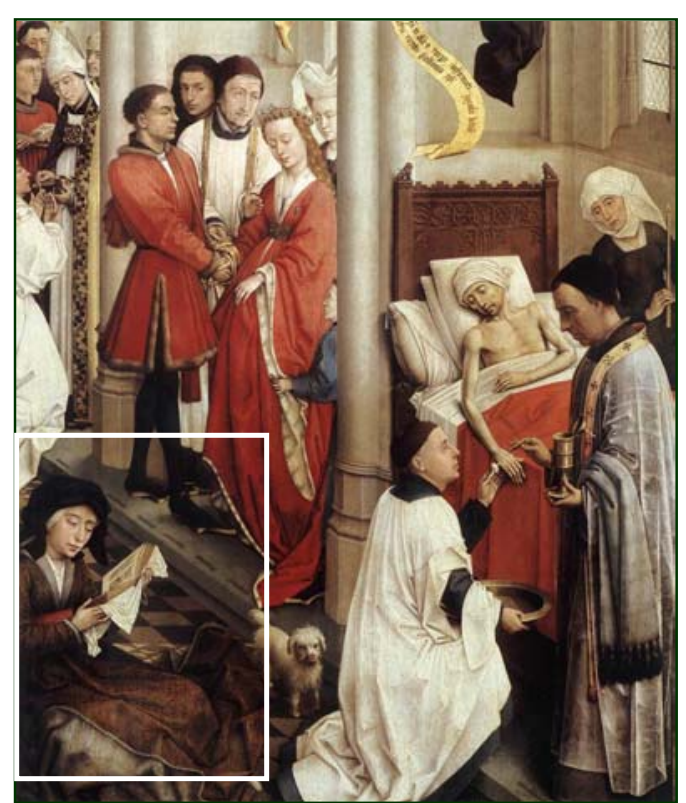

Ilustração 35 WEYDEN, Rogier Van Der. Tríptico dos sete sacramentos, Koninklijk Museum voor Schone Kunsten, Antuérpia. (Detalhe do painel direito). 
A presença do livro como elemento simbólico também pode ser notada em outra obra de Weyden: Anunciação.

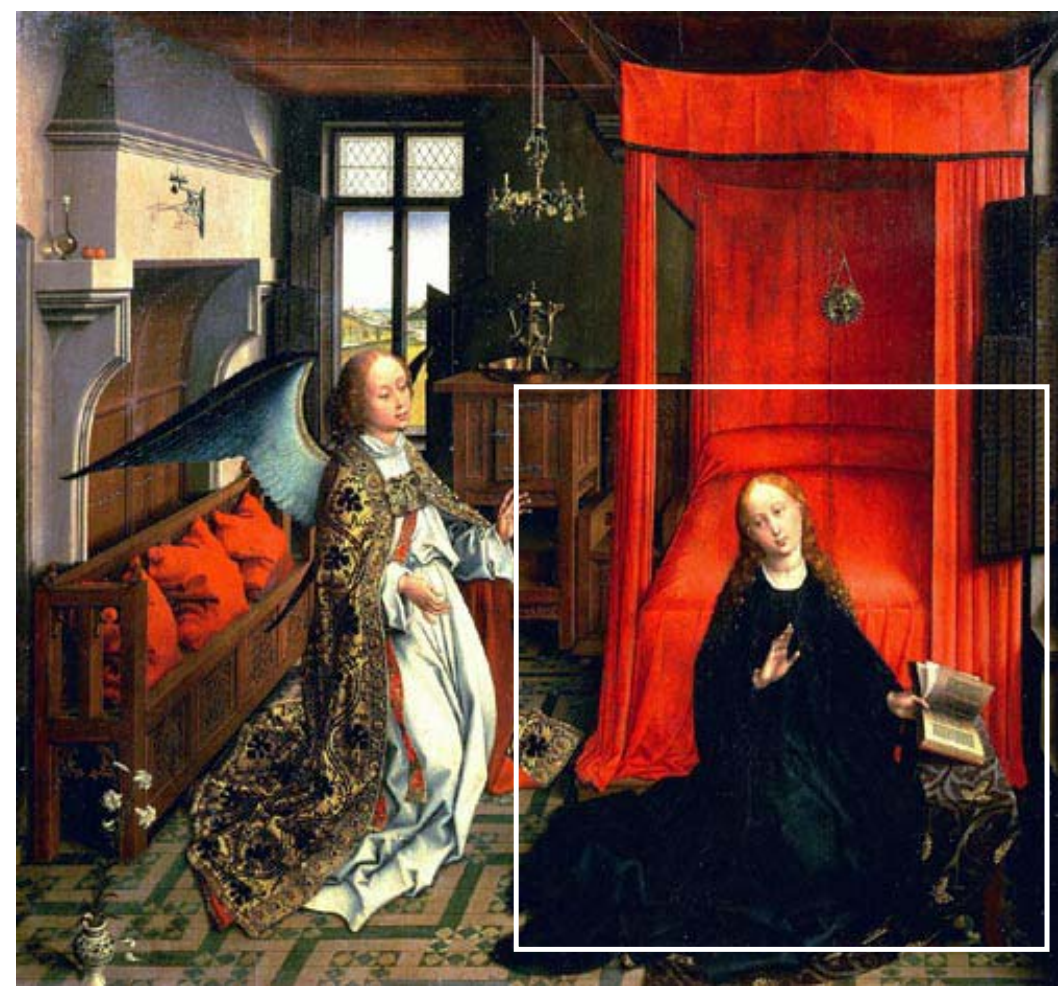

Ilustração 36 WEYDEN, Rogier Van Der. Anunciação, 1435-40, óleo sobre madeira, 86 x $92 \mathrm{~cm}$. Museu do Louvre, Paris - França.

O livro atua em ambas as pinturas como símbolo da sabedoria feminina, uma vez que, naquele contexto histórico, o domínio da leitura não era comum entre as mulheres. A serenidade e autoconfiança das personagens são reafirmadas pela presença do livro.

Vejamos a seguir como as categorias do plano de expressão de que se compõe o Tríptico dos Sete Sacramentos podem ser delimitadas por meio da análise de seus componentes: eidético, cromático e topológico, de tal modo que possamos determinar como os contrastes formados no plano de expressão respaldam a figurativização.

No plano de expressão do enunciado há pertinência do traço e da disposição das imagens. 
No que concerne ao traço, observamos que o quadro considerado se desenvolve por meio da utilização do estilo linear. O sentido, beleza e percepção dos objetos nos são dados por meio de linhas, formas e contornos bem definidos. Por se tratar de uma pintura, pautada pela criação de superfícies por meio da utilização de pigmentos com preenchimento de toda a extensão da tela, verificamos a existência de linhas percebidas e sentidas como limites da superfície. Os olhos são conduzidos dentro dos limites da forma e as imagens são induzidas à percepção tátil. Verificamos também, a presença de linhas claras e delimitadoras, nas quais são discernidas nitidamente uma forma da outra, de tal modo que se tenha uma nítida separação entre fundo e figuras. O plano da expressão de que se constitui o tríptico, ao ser limitado pelos contornos da moldura, dirige o olhar do observador. Ao manifestar o formato de um " $T$ " invertido, o tríptico mostra as ações sacramentais dispostas em uma basílica com três naves. Nestas três naves estão representados o aspecto material sólido e estático dos gestos e ações sacramentais.

No que diz respeito à disposição das imagens, notamos relações lineares entre estas (as imagens) e a superposição lado a lado dos elementos plásticos em seqüências lineares. A disposição da imagem, que regula a colocação do sacramento eucarístico principal em relação aos demais sacramentos, pode ser descrita por meio da categoria intercalado vs. intercalante. 


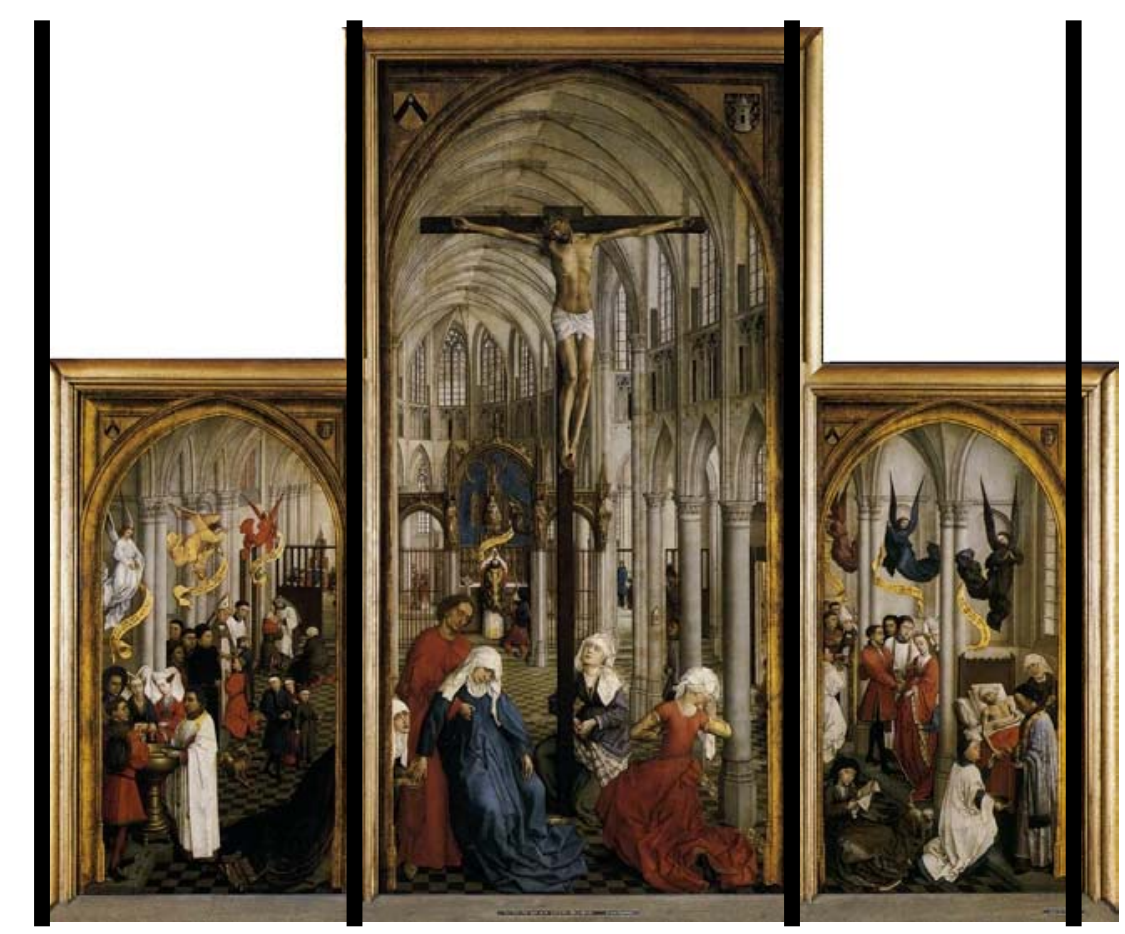

- Distribuição Linear (Intercalado vs. Intercalante)

Com a celebração dos sete sacramentos no interior de uma Igreja, temos uma oposição entre sua estrutura e as ações sacramentais, de tal modo que obtemos dois modos de composição distintos.

Quanto à forma, que pode ser descrita mediante a categoria eidética homogêneo vs. heterogêneo, podemos opor a estrutura arquitetural gótica às ações sacramentais. A homogeneidade da estrutura arquitetural é definida pela regularidade de linhas verticais e as ações sacramentais são associadas à forma heterogeneidade em relação às poses e contornos distintos das celebrações sacramentais. Quanto à disposição das figuras, verificamos os planos para as ações sacramentais e a profundidade para a estrutura arquitetural. A apreensão da totalidade da imagem das ações sacramentais dá-se mediante a categoria multiplicidade, por oposição à unidade do plano de fundo. Quanto ao cromatismo, opõem-se categorias plásticas cromáticas monocromático vs. colorido, no que concerne, respectivamente, à oposição entre o plano de fundo da Igreja e as ações sacramentais. No que diz respeito à categoria plástica 
topológica, temos a articulação entre horizontal (ações sacramentais) e vertical (plano de fundo da Igreja).

A fim de que possamos proceder ao estabelecimento de relações semi-simbólicas, convém que examinemos essas relações a partir do contraste que dá forma às ações sacramentais inseridas no cenário considerado.

Consideramos inicialmente as categorias topológicas, tidas como categorias próprias do plano da expressão, responsáveis pela posição, orientação das formas e movimentos no espaço. A disposição da celebração dos sete sacramentos no enunciado permite o estabelecimento da categoria topológica esquerda vs. direita. Se, no plano do conteúdo, a oposição semântica fundamental é representada por meio da categoria semântica vida vs. morte e se a temática sacramental católica abrange todas as fases da vida de fé do cristão, podemos estabelecer a seguinte relação semi-simbólica: PE (esquerda vs. direita) /PC (vida vs.morte).

A superfície total do tríptico organiza-se em duas faixas intercalantes em paralelismo vertical (painéis direito e esquerdo) e uma faixa intercalada (painel central). A configuração topológica do quadro, por meio da seqüência de representação da temática da liturgia sacramental, que se inicia no Batismo (painel esquerdo) e termina com a Extrema-Unção (painel direito), configura o percurso vida $\rightarrow$ não-vida $\rightarrow$ morte. O painel central, mediante a celebração da liturgia eucarística, representa o termo complexo vida e morte, por ser a própria celebração eucarística fonte e ápice de toda a vida cristã. 


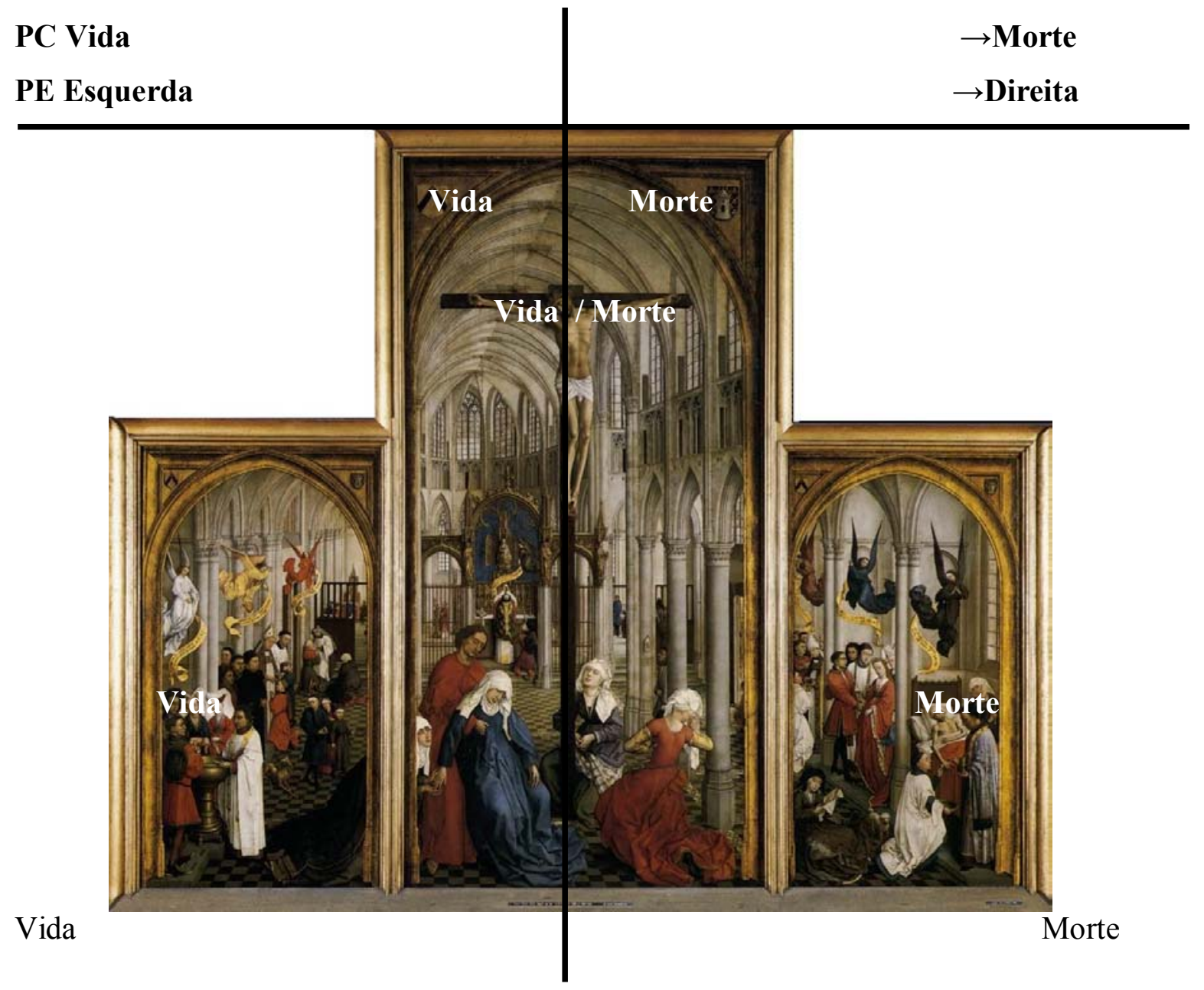

No que se refere à observação das categorias topológicas dadas no painel central, notamos a presença da categoria topológica central vs. marginal.

O sacrifício de Cristo aparece no alto do painel central. A difusão dos dons, enquanto graças instituídas por Cristo em cada sacramento, pode ser representada por linhas que cortam diagonalmente o quadro do alto às posições periféricas e centrais. 


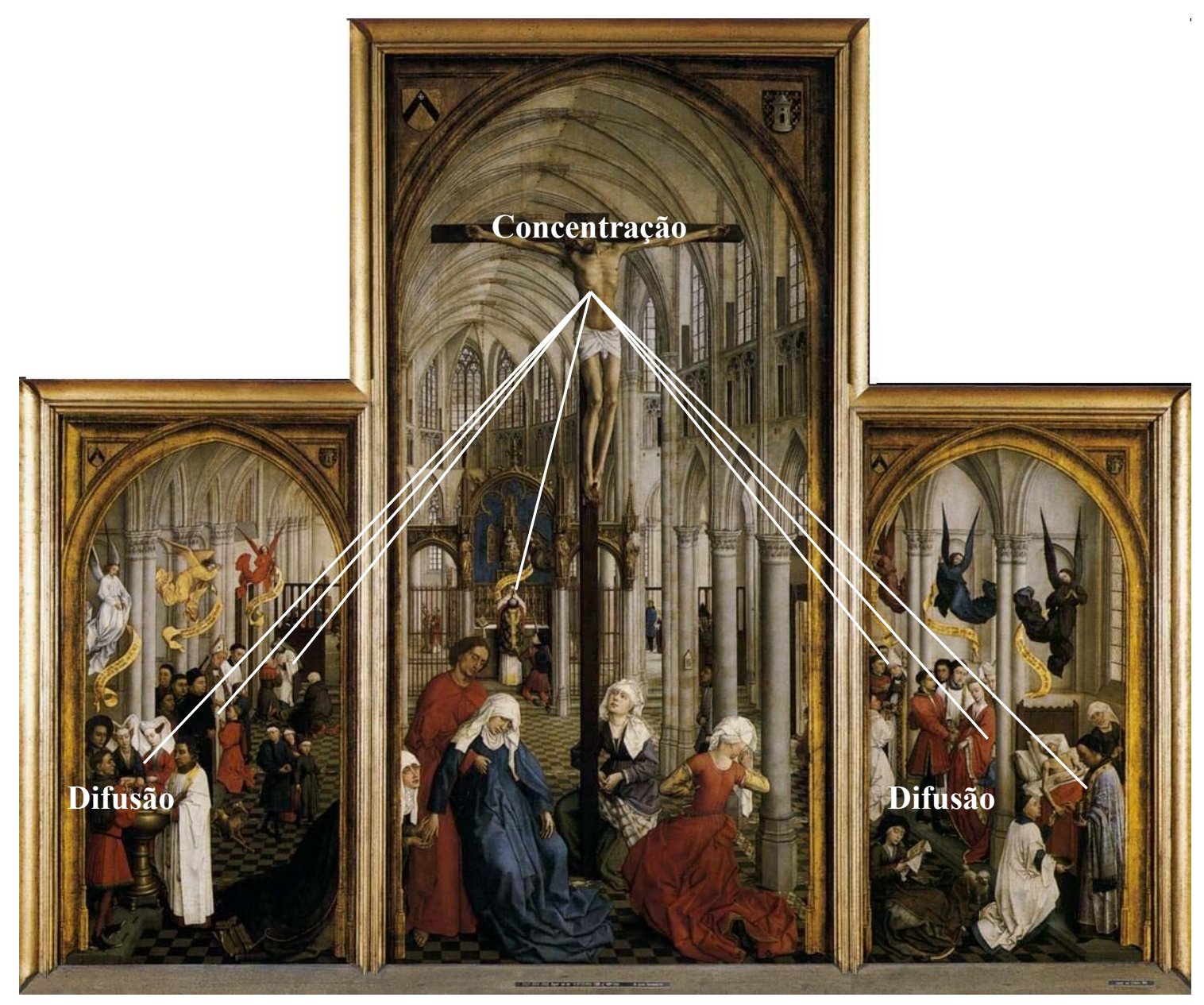

Os ministros responsáveis e os fiéis que recebem os sacramentos estão dispostos no eixo inferior da ilustração, em posição de aceitação e recepção dos valores católicos propostos. Figurativizados pela passividade, eles são modalizados pelo saber, crer e poder estar em conjunção com os valores propostos.

A determinação de uma categoria topológica própria ao plano de expressão, para sua colocação em discurso, permite o estabelecimento de uma zona central e superior de conjunção das linhas (difusão do dom), ao que se opõe uma zona periférica e inferior, na qual figuram sujeitos pautados pela falta patêmica. Desse modo, estabelecemos o seguinte semisimbolismo: PE superior/ PC espiritual e PE inferior/ PC material. Os anjos com as bandeirolas, ao acompanhar a celebração de cada sacramento e ao serem dispostos num plano superior a estes, também configuram a categoria topológica: PE superior/ PC espiritual e PE inferior/ PC material. 


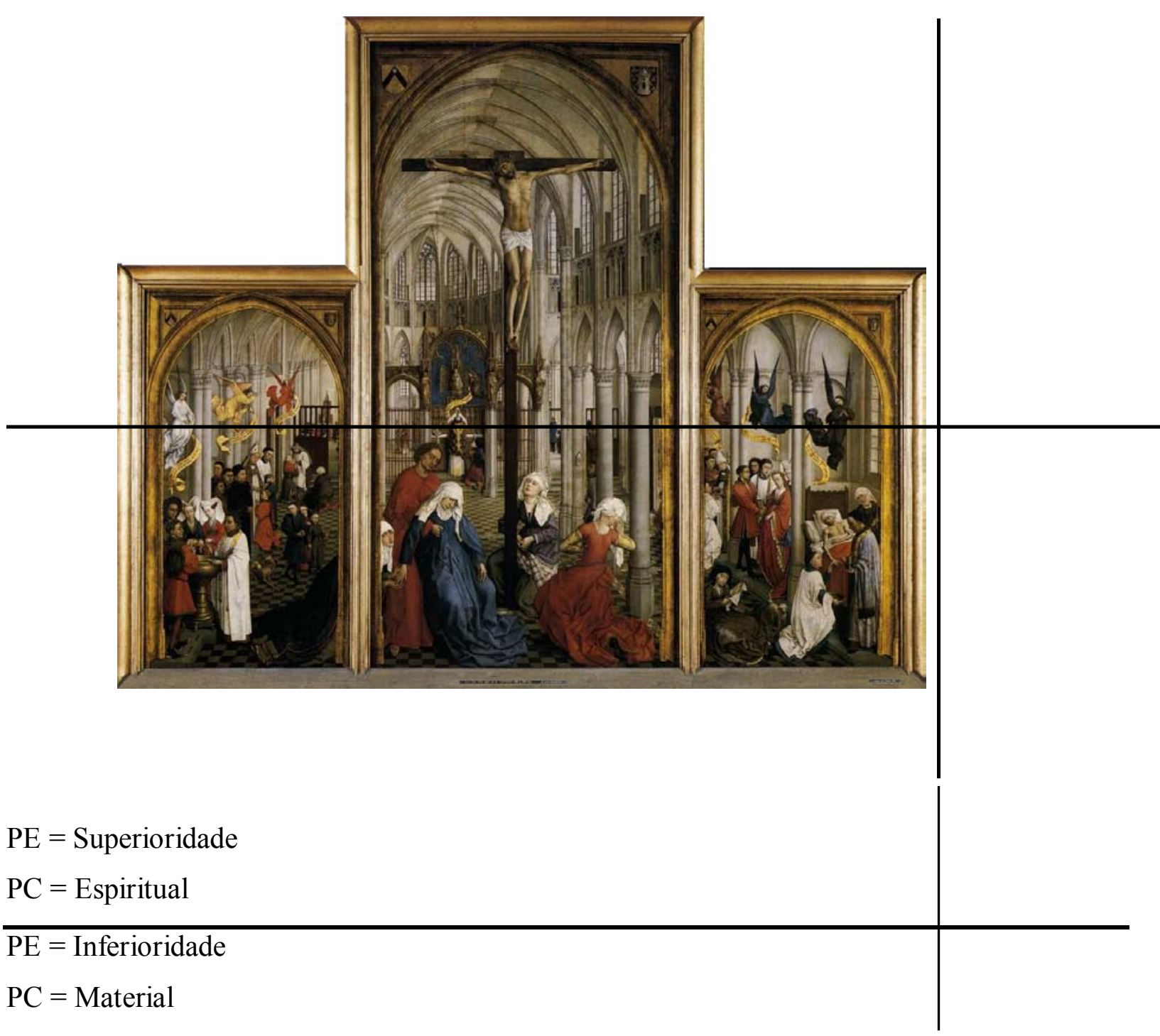

As categorias cromáticas, ao expressar possibilidades de combinações de cores, dadas por meio de oposições cromáticas estabelecidas no espaço da tela, propiciam a instalação de movimento e ritmo da cor dentro do espaço do enunciado plástico considerado.

Desse modo, observemos o cromatismo, de maneira especial, nas cores dos anjos e de suas bandeirolas. A coloração vai escurecendo a medida que se tem a seqüência da celebração sacramental considerada, tendo como limites: o branco para o Batismo e o preto para o sacramento da Extrema-Unção. Ao tomarmos o sentido do percurso vida vs. morte, determinado no plano do conteúdo, podemos estabelecer a seguinte relação semi-simbólica: 
PC vida/ PE cores quentes vs. PC morte/ PE cores frias. Ao que também podemos homologar as categorias PE claro/ PC vida e PE escuro /PC morte.

O cromatismo também permite depreender alguns movimentos simbólicos em conformidade com o sistema católico de valores. Maria, símbolo da Igreja, está revestida com uma túnica azul escura, enquanto João está revestido de uma túnica vermelha.

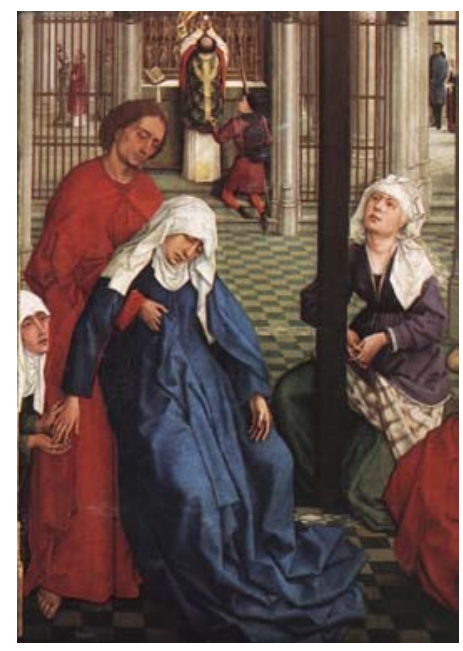

Ilustração 37 WEYDEN, Rogier Van Der. Tríptico dos sete sacramentos, Koninklijk Museum voor Schone Kunsten, Antuérpia. (Detalhe do painel central).

Observamos outro simbolismo na celebração da união matrimonial entre os esposos. A cor vermelha é a cor nupcial mais utilizada na era medieval, pois simboliza "sangue novo" para a perpetuação da família, naquele contexto.

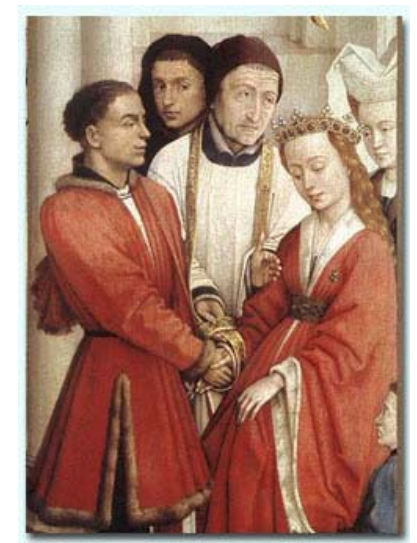

Ilustração 38 WEYDEN, Rogier Van Der. Tríptico dos sete sacramentos, Koninklijk Museum voor Schone Kunsten, Antuérpia. (Detalhe do painel direito). 
Consideremos, agora, a noção de ritmo. Tomaremos essa noção em uma perspectiva tensiva, tendo como base as definições de Zilberberg (1992). Com estes pressupostos, procederemos à análise dos funtivos do andamento que perpassam o discurso iconográfico considerado.

O Tríptico dos Sete Sacramentos demonstra a figurativização dos ritos e sinais sensíveis da celebração dos sacramentos. Ao expor a doutrina sacramental católica, ele prescreve uma série de comportamentos regrados e recorrentes, que devem ser realizados pelo sujeito para que ele possa manter-se em conjunção com o objeto-valor "graça divina". O tríptico se constitui por meio da modalidade do dever-ser, dever-agir de acordo com o modo de vida, cuja receita é dada pela enunciação pressuposta ao enunciado.

Dessa forma, este enunciado, tanto no que concerne à substância plástica, quanto à substância verbal dos atores do enunciado, pode ser associado à estética clássica/ linear. O observador encontra-se pautado pela apreensão do processo e por uma percepção orientada pelo pólo do sagrado.

O Tríptico condiz com a liturgia cerimonial da Igreja católica, caracterizada pela desaceleração e andamento lento, visando à parada da parada e à ritualização de gestos que chamam a atenção para si mesmos (Ex: a administração dos sacramentos). Os contornos bem definidos e a simetria das formas, dos volumes e das cores configuram uma direção de apreensão definida e dominada também pela parada da parada, consolidando, assim, o tom do discurso católico considerado.

Voltemos nossos olhares novamente para o Compêndio do qual retiro o quadro que analisamos. Tal catecismo instaura em suas ilustrações, as figuras de acordo com a perspectiva enunciva. Os rostos sempre estão dispostos de perfil, associados à duração dos gestos cerimoniais. Temos, portanto, um esquema de visão imóvel e contemplativo dos gestos e atitudes concernentes à ritualística católica, ou seja, um ponto de vista estático que 
representa a gravidade dos gestos religiosos, pautados pela lentidão e duração e próprios à estética clássica.

No tríptico, observamos um esquema de visão imóvel e contemplativo do sujeito modalizado pelas paixões do mistério sacrificial de Cristo, o que caracteriza um regime de expansão pautado pelo andamento lento e desaceleração. A expansão e o aumento de perspectiva dos atores do enunciado no painel central ocasionam uma desaceleração. Essas relações são ainda mais explícitas ao observarmos a celebração sacramental católica, de que se compõe o referido enunciado. Na celebração sacramental podemos observar um esquema de visão imóvel e contemplativo dos gestos e atitudes concernentes à ritualística católica.

De modo geral, o Compêndio compõe-se de uma iconografia que ao ser constituída enquanto representativa do sagrado deve evocar a plenitude do ser. Isso configura um esquema de visão imóvel e contemplativo do sujeito caracterizado por uma percepção sacralizada, uma percepção orientada pelo pólo do sagrado.

Para encerrar essa seção, vamos resumir as etapas de nossa análise, a fim de definirmos o estilo e o éthos do ator da enunciação do Compêndio: a) depreendemos as relações entre o plano de expressão e o plano de conteúdo dadas no enunciado; b) estabelecemos inicialmente a análise do plano do conteúdo do referido enunciado; c) em seguida buscamos descrever as categorias do plano de expressão com a observação da relação de homologação entre elas; d) identificamos as relações semi-simbólicas; e) tomamos então o ritmo em uma perspectiva tensiva: um ritmo depreensível das relações semi-simbólicas.

Tendo efetuado essa análise, podemos definir o estilo, o éthos do ator da enunciação do Compêndio. O Compêndio, ao se caracterizar pela presença de um estilo caracterizado pela brevidade, clareza, constantes referências à língua latina e pelo efeito de sacralidade consumado pelas imagens iconográficas, apresenta um éthos professoral, um éthos marcado pela serenidade, um éthos de tom de voz altivo e apegado aos valores da tradição. E com isso, 
podemos ressaltar o efeito de um didatismo peculiar que toma o Tríptico como enunciado visual. 


\section{Brochura de divulgação religiosa (Testemunha de Jeová): O Que Deus Requer de}

Nós?

"Bem longe de dizer que é o objeto que precede o ponto de vista, diríamos que é o ponto de vista que constrói o objeto".

Ferdinand de Saussure ${ }^{16}$

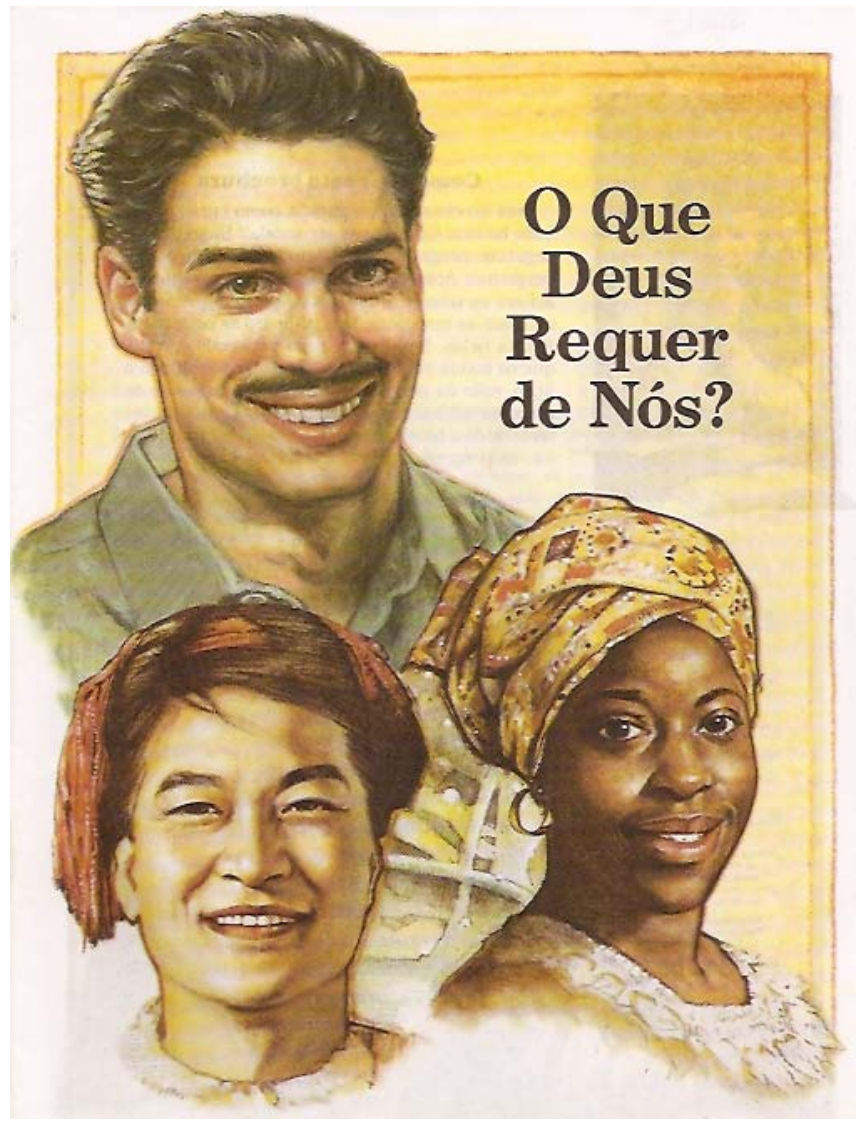

Ilustração 39 Capa da Brochura de Estudo Bíblico: O QUE DEUS requer de nós? São Paulo: Sociedade Torre de Vigia de Bíblias e Tratados, 1996. p. 1.

Consideramos inicialmente a definição do gênero compêndio didático de estudo bíblico como um gênero textual de divulgação religiosa. O compêndio $O$ que Deus Requer de Nós, preparado como um curso de estudo bíblico, ao constituir-se como discurso de divulgação religiosa, configura-se como um gênero textual pertencente à esfera de circulação do discurso religioso da Testemunha de Jeová (doravante TJ). A própria designação do compêndio como brochura de estudo bíblico remete à materialidade do seu sistema de

\footnotetext{
${ }^{16}$ SAUSSURE, Ferdinand de. Curso de Lingüistica Geral. São Paulo: Cultrix, 2004. p. 15.
} 
acabamento. A brochura pode ser caracterizada de acordo com Rabaça e Barbosa (1987, p. 85) da seguinte forma.

Sistema de acabamento que se caracteriza por uma capa mole (plastificada, envernizada ou sem proteção) que envolve os cadernos do livro. "Esses cadernos, reunidos manual ou automaticamente, são, antes de encapados, costurados, grampeados ou colados entre si, do que resulta o miolo do livro" (Amaral Vieira); o miolo é, então, coberto com uma capa de papel ou de cartolina colada ao dorso (RABAÇA; BARBOSA, 1987, p. 85).

A brochura $O$ Que Deus Requer de Nós apresenta uma tiragem fixa, por oposição às revistas de divulgação quinzenal Sentinela e Despertai, também pertencentes à totalidade discursiva das TJ. Ao observar atentamente essa brochura, vemos que ela é publicada em 261 idiomas. O exemplar consultado teve a primeira edição no ano de 1996, com a tiragem total de 171.195.000 exemplares e distribuição em países da Europa, Ásia e África. Segundo Rabaça e Barbosa (1987, p. 85), “a utilização da brochura em larga escala proporciona sensível redução nos custos gráficos e, conseqüentemente, nos preços de cada exemplar, para o público leitor".

Se couber ao analista isolar espaços discursivos como subconjuntos de formações discursivas, que supõe manter "relações privilegiadas, cruciais para a compreensão dos discursos considerados" (cf. MAINGUENEAU, 1997, p. 117), como podemos explicar a questão do "gosto" na escolha de um corpus de pesquisa? Retomamos a máxima saussuriana de que o ponto de vista constrói o objeto. Nosso propósito é elucidar o critério de escolha da brochura de estudo bíblico: O Que Deus Requer de Nós. Como podemos explicar a motivação suscitada pela escolha de um corpus tão "pobre", segundo o olhar do senso comum?

Conceitos como "pobre", "rico", "feio" e "bonito" referem-se ao domínio das normas do gosto associadas à existência modal e semiótica do sujeito do gosto.

O sujeito do gosto possui a paixão da preferência, da predileção. Sua existência modal é dada por um querer ser conjunto com um objeto 
classificado acima dos outros. Nesse sentido, a preferência é um estado de alma que conjuga um desejo, definido por um querer ser, e uma repulsa, uma aversão, caracterizadas por um não querer ser. $O$ gosto de um define-se pela aversão ao gosto dos outros (FIORIN, 1997, p. 16).

Assim, adentramos no domínio das normas do gosto que realizam a oposição do "bom gosto" à sua ausência, o que caracterizaria o "mau gosto" dentro da concepção de uma determinada classe social.

Bourdieu (1979, p. 193) define como estilo de vida "um conjunto unitário de preferências distintivas que exprimem, na lógica específica de cada um dos sub-espaços simbólicos, mobiliário, roupa, linguagem ou héxis corporal, a mesma intenção expressiva."

Desse modo, longe de qualquer posicionamento submisso a determinada norma de gosto, realizaremos a depreensão dos mecanismos argumentativos intrínsecos à transmissão do saber religioso inerentes à brochura considerada, ao que corresponde à depreensão do éthos, do modo de dizer e de habitar o espaço social em que esse discurso se insere. Quais são os mecanismos argumentativos que se ligam à materialidade desse corpus? Quais são os procedimentos argumentativos que estão por trás da escolha de uma "pobreza" material, aos olhos de um determinado olhar? A que corresponde o efeito de sentido de precariedade realizado no texto? Qual é a imagem de enunciatário que esse discurso constrói? Que tipo de leitor ele tem como alvo? Essas são algumas das questões que tentaremos solucionar.

O efeito de sentido de precariedade, determinado pela estratégia de diagramação, tipo de papel e modo de representar figurativamente o mundo, remete, portanto, ao "modo de difusão" (cf. MAINGUENEAU, 2005a, p. 141) operacionalizado pela rede institucional das TJ em relação às características do público a que esse discurso se destina.

A noção de "modo de difusão" se emparelha a noção de "modo de consumo" (cf. MAINGUENEAU, 2005a, p. 141), que corresponde ao modo como esse discurso é lido, consumido e manipulado. 
O modo de difusão das TJ se realiza por meio de uma distribuição abrangente, por atingir vários países, e uma distribuição em larga escala, pois há uma alta tiragem das brochuras.

A brochura $O$ Que Deus Requer de Nós faz parte de um programa gratuito domiciliar de estudo bíblico. Esse programa, de acordo com o boletim enviado a todas as Testemunhas de Jeová no Brasil, intitulado Nosso Ministério do Reino (1999), corresponde ao estudo de uma breve lição da brochura durante 15 a 30 minutos por semana. Desse modo, 15 minutos semanais teriam uma duração média de 16 semanas de curso. O estudo da brochura representa o primeiro degrau para se alcançar o livro Conhecimento Que Conduz à Vida Eterna, o compêndio primário e preferível da totalidade religiosa das TJ.

Preparada como um curso de estudo bíblico, ela se destina a todos aqueles que desejam saber mais sobre a doutrina das TJ e obter um bom conhecimento da verdade bíblica, verdade esta que pode levar o fiel a cultivar a personalidade cristã.

Vejamos como essa instituição discursiviza o perfil do enunciatário nessa brochura:

As pessoas ficam confusas com os conflitantes ensinos religiosos. Precisam de declarações concisas da verdade, apoiadas em vários textos bíblicos que elas possam verificar na sua própria Bíblia. Precisam duma apresentação clara e específica do que Deus requer dos verdadeiros cristãos, e de quais os costumes e práticas que lhe são inaceitáveis. A brochura Deus Requer é exatamente o que precisamos para ajudar a tais a aprender os requisitos de Deus (SENTINELA: Anunciando o Reino de Jeová, 1997, p. 27).

O estudo da brochura consiste, portanto, dentro dessa formação ideológica, na apreensão do conhecimento essencial para que se possa adquirir a salvação eterna. Seu estudo consistiria, portanto, no aprendizado dos requisitos que Deus exigiria dos "verdadeiros" cristãos. Essa característica doutrinária é própria aos discursos “devotos”, "se entendemos por isso enunciados cuja finalidade é menos especulativa do que prática: ensinar aos fiéis quais são os comportamentos que eles devem adotar para viver cristãmente em uma sociedade determinada” (MAINGUENEAU, 2005a, p. 29). 
Ao pertencer à esfera de atividades institucionalizadas da prática religiosa das TJ, a brochura configura-se como um instrumento autorizado que contém os elementos fundamentais de sua doutrina. Dirigida à população em geral, ela se apresenta como um curso de estudo bíblico, um manual de instrução fundamental da doutrina das TJ, no qual se abre a possibilidade para que se possa conhecer aquilo que tal instituição professa, celebra e prega na doutrina cotidiana. Desse modo, a brochura constitui um instrumento de pregação e de ensino, cujo objetivo é fazer novos discípulos.

A Palavra Revelada é instituída como fonte primeira a esse discurso que tem por objetivo a manipulação do destinatário, a fim de que este queira e deva entrar em conjunção com o ensinamento da Sagrada Escritura.

Dentro dos propósitos e limites deste trabalho, estabelecemos como recorte textual a análise da Lição 11: "Crenças e costumes que desagradam a Deus”, extraída da brochura de estudo bíblico: O que Deus Requer de Nós, da totalidade discursiva das T. J.

Na tentativa de delinear o modo de presença, o éthos do ator da enunciação como tom, voz, caráter e corporalidade da unidade (unus) considerada para análise, levaremos em conta a totalidade (totus), da qual fazem parte as seções de que se constitui a brochura de estudo bíblico: O que Deus requer de nós.

Ao considerar os desenvolvimentos de Teixeira (2004), e ao tomar a lição considerada como um produto sincrético, a análise:

deverá considerar, em primeiro lugar, a co-ocorrência de elementos verbais e visuais constituindo uma unidade de sentido, um todo coerente e integrado. A diagramação, as fotografias, os textos, as margens e limites, a titulação, as manchetes - todos esses elementos se integram para produzir um efeito de totalidade. [...] A análise, portanto, deve acompanhar esse movimento de leitura, atenta à contigüidade dos elementos e à associação entre plano de expressão (PE) e plano do conteúdo (PC). Numa abordagem semiótica, tanto importa o que se diz quanto o modo de dizer, já que é na articulação entre os elementos materiais e os aspectos conceituais e referenciais que o sentido se produz. Assim, a diagramação da página é tão relevante para a informação quanto o conteúdo das matérias (...) (TEIXEIRA, 2004, p. 151-153). 
Contemplemos, inicialmente, a composição diagramática da capa da brochura de estudo bíblico, retomada a seguir:

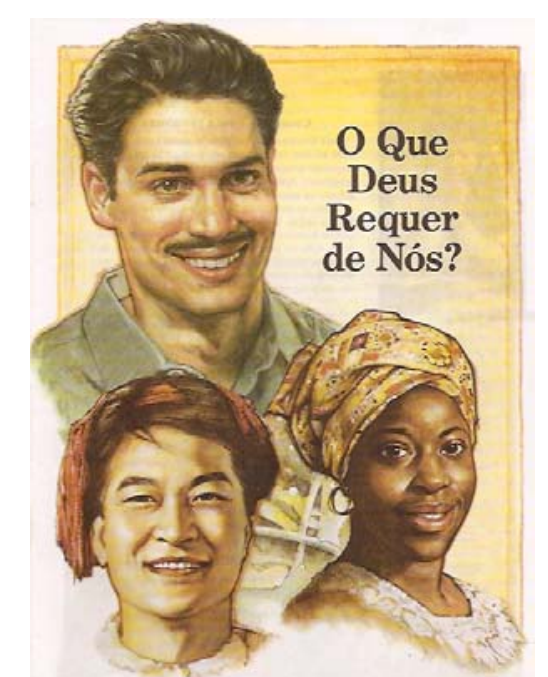

Ilustração 40. Capa da Brochura de Estudo Bíblico: O QUE DEUS requer de nós? São Paulo: Sociedade Torre de Vigia de Bíblias e Tratados, 1996. p. 1.

Tomemos a definição de capa apresentada por Rabaça e Barbosa (1987, p. 104):

Como embalagem de livro, revista ou disco, é o primeiro contato visual do consumidor com o produto, motivo pelo qual é proporcionalmente utilizada para atrair a atenção sobre o produto, informando sobre seu conteúdo e distinguindo-o dos demais nas estantes e nas prateleiras (RABAÇA; BARBOSA, 1987, p. 104).

A capa da brochura considerada apresenta o título-síntese do conteúdo, que se desenvolverá no texto da brochura através da exposição do que são considerados os requisitos a serem seguidos pelos verdadeiros cristãos.

Três atores, dois homens e uma mulher, simetricamente dispostos na capa da brochura, constituem a figurativização da temática da oposição entre três raças: branco, negro e asiático. Os três personagens preenchem todo o espaço da página, deixando espaço apenas para o título síntese do desenvolvimento da brochura: O Que Deus Requer de Nós. 
Quanto à disposição dos personagens na página, verificamos que ela segue uma visão em profundidade sob um fundo emoldurado em tom dourado, o que confere um aspecto de livro envelhecido, ao que se poderia associar um simulacro de autoridade dado pela tradição. As imagens se expandem além dos limites definidos pela moldura. A atenção deixa de se concentrar nas margens e limites, a fim de que se obtenha uma visão globalizada, integradora e unificadora do conjunto. Os contornos não acentuados favorecem a ligação entre as figuras, denotando certa identidade entre elas.

As figuras são apresentadas em semi-perfil do meio tronco para cima, em um leve movimento do tronco e da cabeça para a direita, sem tensão, ou seja, tranqüilos. O movimento do olhar dos atores se dirige ao enunciatário, o que caracteriza um efeito de sentido de aproximação e identificação entre enunciador e enunciatário. O enunciatário, feixe de expectativas desse discurso, ao ser instaurado na materialidade visual da capa da brochura, acaba por possuir uma identificação imediata. O caráter exemplar dessa imagem visual leva o enunciatário a se identificar com os personagens figurativizados na capa da brochura.

No que diz respeito à categoria de pessoa, temos uma debreagem enunciativa de primeiro grau obtida pela instauração da pergunta delegada pelo narrador aos actantes do enunciação enunciada: $O$ que Deus requer de Nós. Há nessa debreagem o simulacro de uma interação entre narrador (autor) e narratário (leitor).

Temos, portanto, por meio da reiteração entre o verbal e o visual na capa, um contato mais acentuado, íntimo, participativo e integrador do enunciatário.

Esses procedimentos expressivos dados pela aparência dos personagens, que estão sorridentes, apaziguados e em tom de identificação com o enunciatário, permitem a instauração de um efeito de sentido de identidade e cumplicidade no plano do conteúdo (PC).

A presença desses procedimentos expressivos, que relacionam o visual em relação de completude com o verbal, ao neutralizar, pela identidade do PE os conflitos de raça, 
confirmam no PC a temática da ausência do ódio e do preconceito referendada pelas estratégias discursivas dessa totalidade discursiva.

Observaremos, a seguir, a quarta capa, representativa, portanto, da última página da brochura:

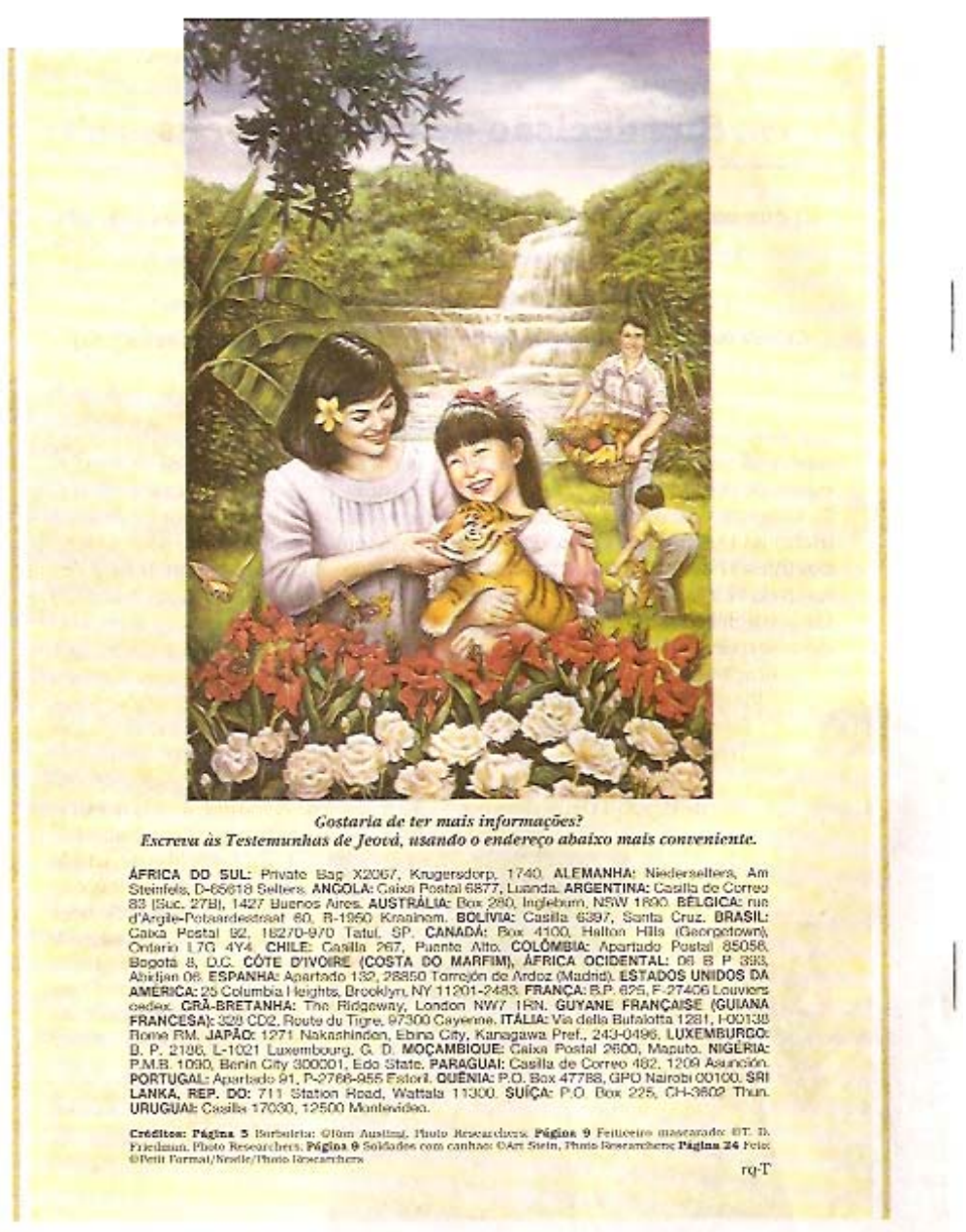

Ilustração 41 O QUE DEUS requer de nós? São Paulo: Sociedade Torre de Vigia de Bíblias e Tratados, 1996. p.32.

Verificamos uma ilustração disposta de maneira central e no alto da última capa. Notamos a figurativização de um momento descontraído de uma família feliz, em um mundo harmonioso, abundante e pacífico. O modo de apresentação dos atores do enunciado dessa ilustração estaria relacionado, portanto, às paixões representativas da tranqüilidade, 
apaziguamento e relaxamento no plano do conteúdo (PC). Essa imagem visual reitera a temática do paraíso idílico e feliz pertencente à ideologia religiosa das TJ.

Estas seqüências verbais e visuais, recortadas da brochura referida, comprovam o mundo tematizado e figurativizado como um mundo da ordem e da harmonia:

6. Durante o Reinado Milenar de Jesus, humanos fiéis trabalharão para transformar toda a Terra num paraíso. (Lucas 23:43) Também, milhões de mortos serão ressuscitados para a vida humana na Terra. (Atos 24:15) Se fizerem o que Deus requer deles, continuarão a viver na Terra para sempre. Do contrário, serão destruídos para sempre. — João 5:28, 29; Revelação 20:11-15(O QUE DEUS requer de nós, 1996, p. 11).

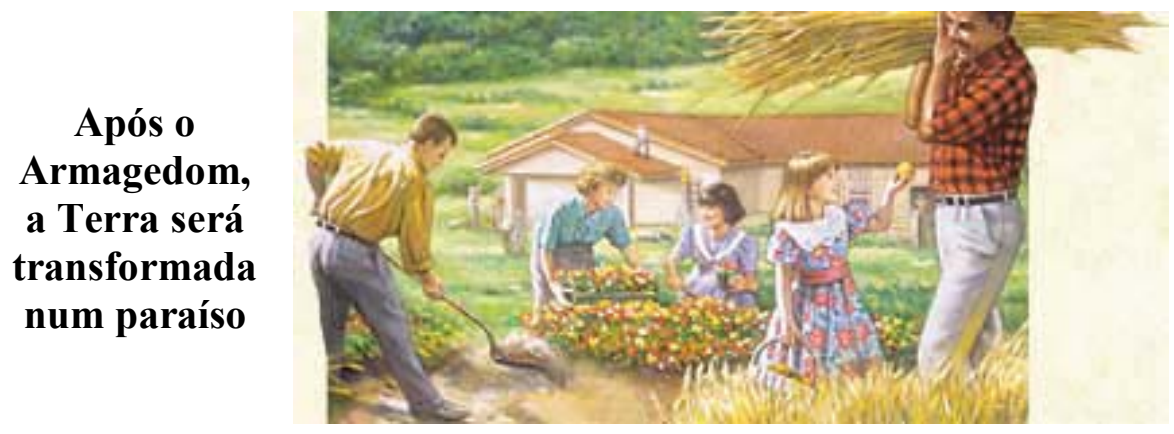

Ilustração 42 O QUE DEUS requer de nós? São Paulo: Sociedade Torre de Vigia de Bíblias e Tratados, 1996. p.11.

7. Durante o Reinado Milenar de Jesus, os humanos fiéis se tornarão perfeitos e toda a Terra se tornará um paraíso. Ao fim dos mil anos, Jesus terá feito tudo o que Deus lhe mandou fazer. Então ele entregará o Reino de volta ao Pai. (1 Coríntios 15:24) Por que não contar aos seus amigos e entes queridos o que o Reino de Deus fará? (O QUE DEUS requer de nós, 1996, p. 13).

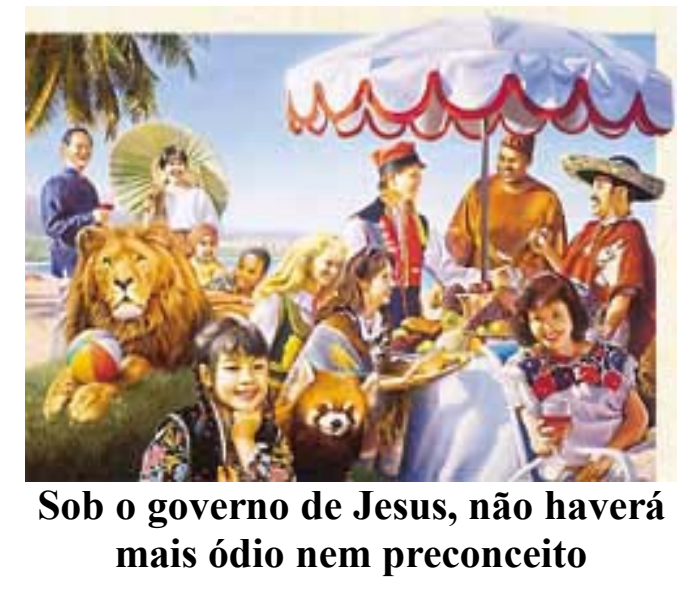


Ilustração 43 O QUE DEUS requer de nós? São Paulo: Sociedade Torre de Vigia de Bíblias e Tratados, 1996. p.13.

Esse mundo perfeito, ordenado e harmonioso, corresponderia ao $\mathrm{O}_{\mathrm{v}}$ "salvação eterna", obtido por aqueles que cumprirem adequadamente os preceitos divinos expostos na brochura de estudo bíblico.

Ainda na quarta capa, em disposição central, também são apresentados os endereços para que se possa obter mais informações sobre a doutrina das TJ. Abaixo dos endereços, estão dispostos os créditos das fotos utilizadas na brochura.

Vejamos, a seguir, a composição diagramática da contracapa da brochura de estudo bíblico. Rabaça e Barbosa (1987, p. 172) nos apresentam a seguinte definição para contracapa: "Cada um dos lados internos da capa de um livro, livreto ou revista. Segunda e terceira capas (...)".

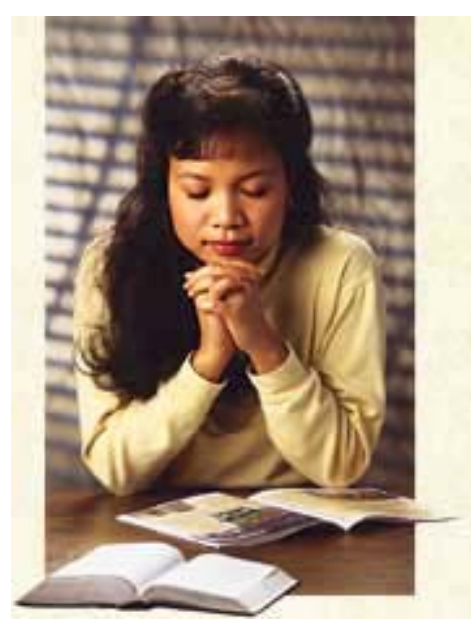

\section{Como usar esta brochura}

Esta brochura foi preparada como curso de estudo bíblico. Como deve ser usada? Sugerimos o seguinte programa: no início de cada lição há perguntas. Após cada pergunta, entre parênteses, achará os números dos parágrafos em que se encontram as respostas. Leia primeiro as perguntas. Reflita nelas. Depois leia cada parágrafo e verifique os textos na sua Bíblia. Após ter terminado a lição, volte às perguntas e procure lembrar-se da resposta bíblica a cada uma delas. Quando tiver terminado a brochura inteira, volte e recapitule todas as perguntas. 
Watch Tower Bible and Tract

Society of Pennsylvania

Sociedade Torre de Vigia de Bíblias e Tratados

Todos os direitos reservados

O Que Deus Requer de Nós?

Editoras:

Watchtower Bible and Tract Society of New York, Inc.

International Bible Students

Association, Brooklyn, New York U.S.A.

Sociedade Torre de Vigia de Bíblias e Tratados, Rodovia SP-141, km 43,

18285-000 Cesário Lange, SP, Brasil

Esta brochura é publicada em 261 idiomas

Total impresso de todas as edições: 171.195.000 exemplares

A menos que haja outra indicação, as citaçōes đa Bíblia são da Traduçāo do Novo Mundo das

Escrituras Sagradas, em linguagem moderna, impressão de 1992

What Does God Require of Us? Portuguese (Brazilian Edition) Edição brasileira $(r q-T)$

Made in Brazil Impresso no Brasil

\section{Conteúdo}

1. Como você pode saber o que Deus requer 3

2. QueméDeus? 4

3. Quemé Jesus Cristo? 6

4. Quemé oDiabo? 8

5. Qualéo propósito de Deus para com a Terra? 10

6. Oqué o Reino de Deus? 12

7. Como achegar-sea Deus emoração 14

8. Avida familiarque agradaa Deus 16

9. Os servos de Deus têm de ser puros e limpos 18

10. Práticas que Deus odeia 20

11. Crenças e costumes que desagradam a Deus 22

12. Respeito pela vida e pelo sangue 24

13. Como você pode encontrar a religião verdadeira? 26

14. Como as Testemunhas de Jeová estāo organizadas 28

15. Como ajudar outros a fazer a vontade de Deus 30

16. Sua decisão de servir a Deus 31 


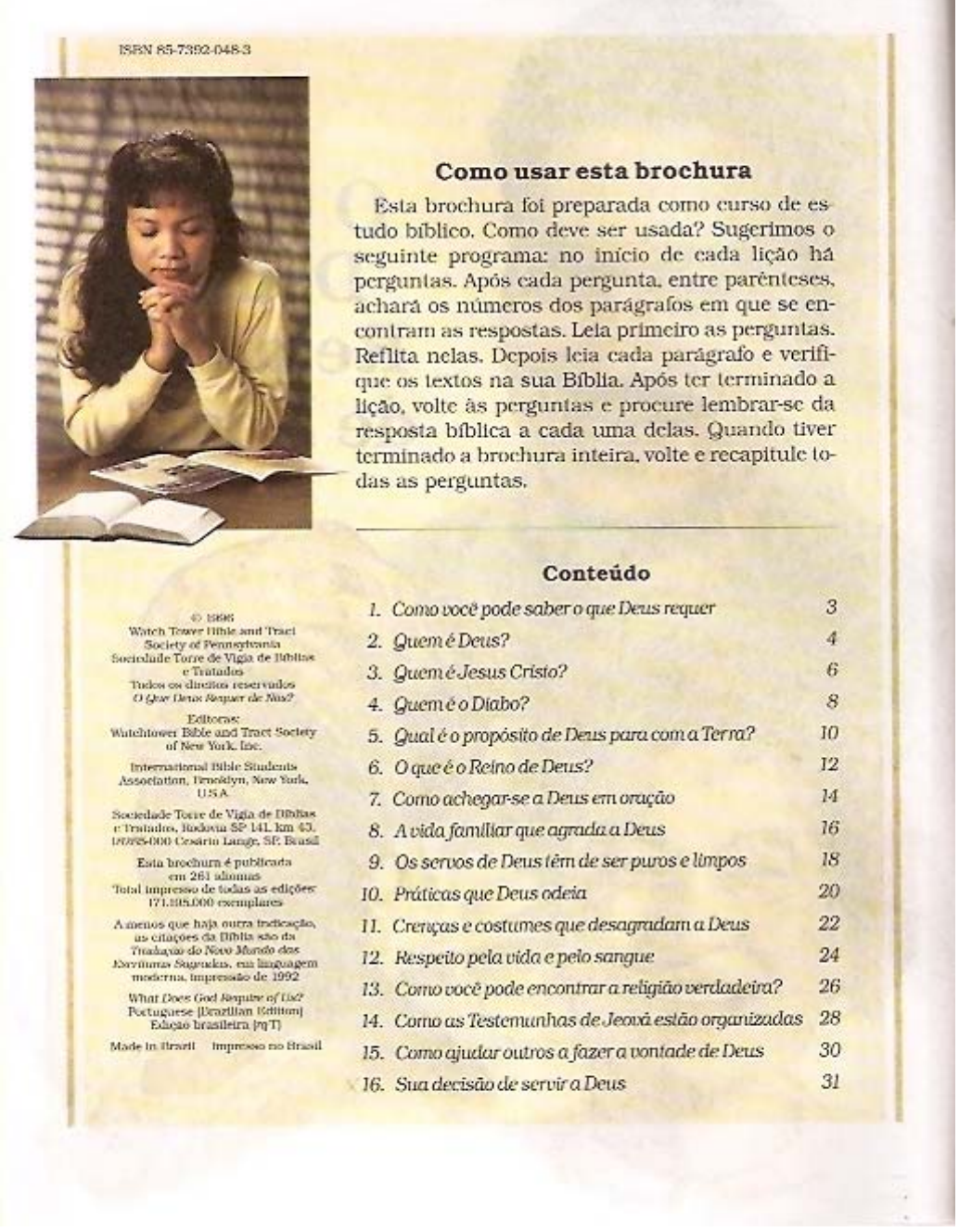

Ilustração 44 Contracapa da Brochura de Estudo Bíblico: O QUE DEUS requer de nós? São Paulo: Sociedade Torre de Vigia de Bíblias e Tratados, 1996. p.2.

Ao analisar a contracapa, observamos que a metade superior direita da página é ocupada por um texto injuntivo sincrético: "Como usar essa brochura".

\section{Como usar esta brochura}

Esta brochura foi preparada como curso de estudo bíblico. Como deve ser usada? Sugerimos o seguinte programa: no início de cada lição há perguntas. Após cada pergunta, entre parênteses, achará os números dos parágrafos em que se encontram as respostas. Leia primeiro as perguntas. Reflita nelas. Depois leia cada parágrafo e verifique os textos na sua Bíblia. Após ter terminado a lição, volte às perguntas e procure lembrar-se da resposta bíblica a cada uma delas. Quando tiver terminado a brochura inteira, volte e recapitule todas as perguntas (O QUE DEUS requer de nós, 1996, p. 2). 
Esse texto é pautado pelo tom injuntivo e pelas modalidades deônticas, pois descreve uma série de comportamentos regrados e recorrentes de como proceder para a adequada utilização do manual.

Observamos a presença de uma fotografia disposta no alto à esquerda:

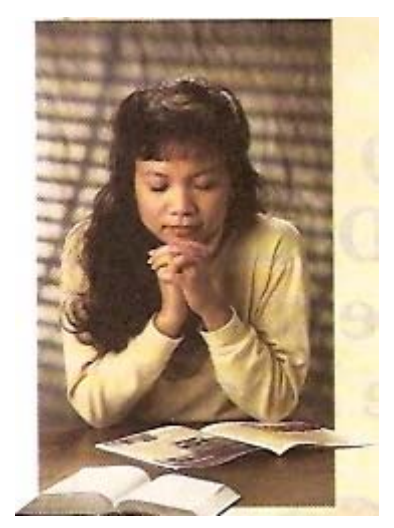

Ilustração 45 O QUE DEUS requer de nós? São Paulo: Sociedade Torre de Vigia de Bíblias e Tratados, 1996. p.2.

O corpo do ator do enunciado é apresentado em posição frontal, com a cabeça rebaixada e as mãos dispostas em posição de oração. Dessa maneira, o modo próprio de representação se associa ao relaxamento, tranqüilidade e passividade no PC. O ator do enunciado, a menina, figurativizado pela passividade, é modalizado através do saber, poder e crer poder entrar em conjunção com os valores propostos. Na metade inferior da página, à esquerda, verificamos a presença dos dados de editoração. À direita, temos o sumário que resume o conteúdo da brochura com predominância do tom injuntivo. As perguntas retóricas são predominantes. A estratégia básica das lições, colocadas em sua maioria sob a formulação de questões, adquire a forma imperativa através da instituição de perguntas retóricas.

A isotopia pedagógica que caracteriza o estilo professoral e didático é coerente com os gêneros de divulgação religiosa. Desse modo, observamos que o conteúdo temático da brochura, pautado pela facilitação do conhecimento em relação a Deus e à Palavra Revelada, desenvolve-se por meio de sua composição em 16 lições. 
Tomemos como base a lição 16 "Sua decisão de servir a Deus", a fim de examinar a estrutura composicional do enunciado considerado. Transcreveremos a lição a seguir:

\author{
Lição 16 \\ Sua decisão de servir a Deus
}

\title{
O que você precisa fazer para se tornar amigo de \\ Deus? $(1,2)$
}

\section{Como se dedica a vida a Deus? (1)}

\section{Quando deve ser batizado? (2)}

\section{Como você pode obter a força para continuar fiel a Deus? (3)}

1. Para se tornar amigo de Deus, você precisa obter um bom conhecimento da verdade bíblica (1 Timóteo 2:3, 4), ter fé nas coisas que aprendeu (Hebreus 11:6), arrepender-se dos pecados (Atos 17:30,31), e dar meia-volta no rumo da vida que leva. (Atos 3:19) Então seu amor a Deus deve movê-lo a dedicar-se a ele. Isto quer dizer que numa oração pessoal, particular, você lhe diz que se entrega a ele para fazer a Sua Vontade. - Mateus 16:24; 22:37.

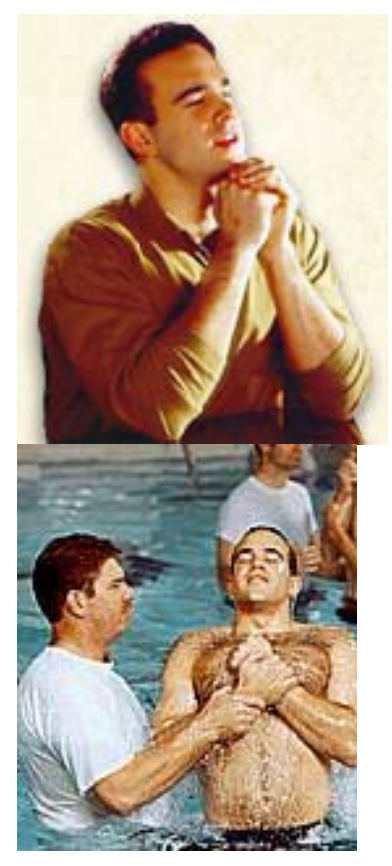

2. Depois de você ter se dedicado a Deus, deve ser batizado. (Mateus 28:19, 20) O batismo deixa todos saber que você se dedicou a Jeová. Por isso, o batismo é apenas para os que já têm idade suficiente para tomar a decisão de servir a Deus. Quando se batiza alguém, todo o seu corpo deve ser imerso na água por um momento.* - Marcos 1:9, 10; Atos 8:36.

3. Depois de você ter feito a dedicação, Jeová espera que viva à altura dessa promessa. (Salmo 50:14; Eclesiastes 5:4, 5) O Diabo procurará impedi-lo de servir a Jeová. (1 Pedro 5:8) Mas achegue-se a Deus em oração. (Filipenses 4:6, 7) Estude a Palavra Dele todos os dias. (Salmo 1:1-3) Mantenha-se unido à congregação. (Hebreus 13:17) Por fazer tudo isso, obterá a força necessária para continuar fiel a Deus. Assim poderá fazer por toda a eternidade as coisas que Deus requer de você!

Em preparação para o batismo, recomenda-se o estudo de Conhecimento Que Conduz à Vida Eterna ou de um livro similar, publicado pela Sociedade Torre de Vigia de Bíblias e Tratados (O QUE DEUS requer de nós, 1996, p. 2).

No que concerne à coerção genérica de sua exposição, o enunciado considerado mostra a seguinte estrutura em todas as lições que o constituem: a) número da lição disposto 
no alto da página; b) título da lição em negrito; c) perguntas no início da lição; d) numeração dos parágrafos entre parênteses, nos quais se encontra desenvolvido no texto a explanação das respostas; e) disposição do texto em colunas; f) presença de ilustrações (fotografias) que acompanham a lição; g) citações de autoridade bíblica.

O visual sincretizado ao verbal na brochura de divulgação religiosa das TJ é discursivizado como expansão das figuras verbais, apresentando, portanto, devido ao predomínio do sincretismo por convergência, o icônico em relação de completude com o verbal, viabilizando a leitura linear e facilitada, própria ao tom professoral.

O plano de expressão (PE) é caracterizado pela utilização de letras de grandes dimensões, sincretismo verbo-visual convergente, entrelaçamento diagramático (associação numérica das questões introdutórias com as explanações ao longo do texto), respiro entre as colunas e utilização de letras em itálico para destaque. Por sua vez, a homologação semisimbólica do plano de expressão ao plano do conteúdo remete ao tom professoral do éthos mediador.

A composição da brochura em 16 lições constitui-se num "crescendum” que modaliza o leitor para poder e saber examinar e assimilar as verdades bíblicas. Vejamos como esse "crescendum" organiza-se na brochura, ao examinar resumidamente o conteúdo das dezesseis lições.

Tomemos o enunciado da brochura, da lição 1 à 16: Lição 1, “Como você pode saber o que Deus requer?”; Lição 2, “Quem é Deus?”; Lição 3, “Quem é Jesus Cristo?”; Lição 4, “Quem é o Diabo?”; Lição 5, “Qual o propósito de Deus para com a Terra?”; Lição 6, “O que é o reino de Deus?”; Lição 7, “Como achegar-se a Deus em oração"; Lição 8, "A vida familiar que agrada a Deus"; Lição 9, "Os servos de Deus têm de ser puros e limpos"; Lição 10, "Práticas que Deus odeia"; Lição 11, "Crenças e costumes que desagradam a Deus"; Lição 12, "Respeito pela vida e pelo sangue"; Lição 13, "Como você pode encontrar a religião 
verdadeira?”; Lição 14, “Como as Testemunhas de Jeová estão organizadas”; Lição 15, “Como ajudar os outros a fazer a vontade de Deus"; Lição 16, "Sua decisão de servir a Deus". As lições de 1 a 6 apresentam a fé professada pelas TJ, incluindo a crença na autoridade da Bíblia, em Jeová como único Deus verdadeiro e no propósito de Jeová em tornar a Terra um paraíso, no qual a humanidade habitaria eternamente.

As lições de 7 a 9 expõem as práticas a serem executadas pelos "verdadeiros cristãos". Dentre essas práticas podemos destacar: a) a importância da oração; b) uma adequada conduta familiar; c) um modelo de pureza ser exercido em todos os sentidos: espiritual, moral e físico.

As lições 10 a 12 apresentam as práticas relativas à moral, crenças e costumes a serem evitadas por aqueles que almejam a salvação eterna, pois, segundo esse discurso, "aqueles que praticam as coisas que Deus diz que são más não herdarão o reino de Deus" (O QUE DEUS requer de nós, 1996, p. 21).

Ao longo das lições 13 a 15 são apresentadas as características das Testemunhas de Jeová, sua história e organização ao redor do mundo.

Na lição 16, o narratário (leitor), ao ter adquirido o conhecimento da verdade bíblica e das práticas do verdadeiro cristão requeridas por Deus, deveria decidir dedicar-se a ele. A lição expõe ainda a manutenção das práticas divinas, para que se possa adquirir o objeto modal "poder ter força para resistir aos assaltos da tentação".

Assim, podemos depreender, no que concerne à enunciação dessa brochura, a “competência discursiva do sujeito para fazer, e aqui, fazer cognitivamente, ou realizar-se na performance cognitiva que é a decisão" (DISCINI, 2005b, p. 275).

Vejamos como Greimas (1983, p. 87) apresenta a definição da performance cognitiva da decisão:

Um conjunto de posições modais do sujeito pragmático no momento em que ele preenche as condições necessárias para a conclusão do contrato, no momento pois que o destinador já transmitiu, com a ajuda da modalidade 
factitiva, o conteúdo deôntico de sua mensagem. O sujeito, dotado de duas modalidades distintas, se encontra em uma posição que pode dar lugar a aceitação (no caso da compatibilidade modal), seja a recusa no caso da incompatibilidade do contrato (asserção e negação) relevante da performance cognitiva que é a decisão (GREIMAS, 1983, p. 87).

A performance cognitiva do sujeito deve culminar em sua decisão de servir a Deus apresentada na lição 16. A performance da decisão, pelo caráter de necessidade ideal e moral, reduz o caráter coercitivo e impositivo da obrigação, que apresenta uma coerção mais intensa exercida sobre o dever-fazer do enunciatário.

Assim, o programa narrativo de base que rege este discurso pode ser descrito como se segue:

$\mathrm{SN}=$ Programa narrativo de base (construção de significado pelo enunciatário por intermédio da enunciação)

$$
\begin{aligned}
& \mathrm{F} \rightarrow\left[\mathrm{S}_{1} \rightarrow\left(\mathrm{S}_{2} \cap \mathrm{O}_{\mathrm{v}} \text { graça divina }\right)\right] \\
& \mathrm{F}=\text { fazer-saber (saber sobre o ser dos valores/ saber sobre o fazer) }
\end{aligned}
$$

Apresentar as verdades presentes nas Sagradas Escrituras, enquanto transmissão de um modelo de conduta exemplar.

Exposição dos princípios da fé, moral e prática dos "verdadeiros cristãos".

$$
\begin{aligned}
& \mathrm{S}_{1}=\text { enunciador da brochura instrucional (comentador) } \\
& \mathrm{S}_{2}=\text { leitor-aprendiz } \\
& \mathrm{O}_{\mathrm{v}}=\text { graça divina (aquisição do conhecimento que conduz à salvação eterna) }
\end{aligned}
$$

Os preceitos bíblicos, ao serem narrados em sua progressão, pressupõem relações de anterioridade e posterioridade entre as lições consideradas. Observamos que o PN de base, que rege o enunciado da lição 16 "Sua decisão de servir a Deus", apresenta o Sujeito $\mathrm{S}_{1}$ 
fazendo com que $S_{2}$ entre em conjunção com o Ov "graça divina", por meio da performance da decisão. O PN de atribuição da competência (ter o saber necessário para adquirir a salvação eterna) teria sido efetuado nos PNs de base que remontam às lições anteriores.

O destinador-manipulador, graças ao poder que lhe foi conferido, busca estabelecer um contrato fiduciário com o destinatário-sujeito por meio da crença na palavra revelada pela divindade (Jeová), que é, por sua vez, obtida e conservada através das Sagradas Escrituras.

Observamos que a modalização factitiva estabelece a instauração de um programa de ação neste discurso por meio de um percurso de um fazer-fazer, ou seja, o destinador, ao operar com a revelação dos saberes bíblicos presentes nas Sagradas Escrituras e ao transmitir o saber sobre o ser dos valores e sobre o fazer das TJ, quer fazer com que o outro, o destinatário, realize a performance tida como desejável a esse sistema de valores. $\mathrm{O}$ destinador-manipulador busca a adesão do destinatário-sujeito, por meio da manipulação executada na ordem do querer e saber-fazer, ao lhe apresentar a exemplaridade do percurso desenvolvido pelo verdadeiro cristão.

Com relação aos recursos argumentativos empregados pelo enunciado instrucional para divulgar e legitimar a autoridade da cena fundante, observamos a utilização de uma estratégia discursiva efetuada de modo explícito por meio da utilização de lições. Assim, observamos que a ação simbólica mobilizada por esse discurso consiste em incutir valores ideológicos, éticos e morais em conformidade com a formação ideológica na qual o sujeito se acha instaurado.

Desse modo, o enunciado do texto instrucional das Testemunhas de Jeová, para divulgar e legitimar a autoridade da cena fundante, exibe uma argumentação que leva o crente a querer-ser o ator do enunciado "verdadeiro cristão", tido como modelo de conduta a ser seguida. 
Se tomarmos como base os procedimentos argumentativos estabelecidos por Perelman e Olbrechts-Tyteca (2005, p. 413), concernentes às ligações que fundam a estrutura do real, no que diz respeito ao fundamento pelo caso particular, a estratégia argumentativa empregada é a argumentação pelo exemplo.

Dessa maneira, a cenografia considerada para análise confirma a prescrição de um modo de dizer do gênero discurso de divulgação religiosa. A brochura apresenta-se como um tipo textual injuntivo, com a exposição de prescrições a serem realizadas a fim de se atingir um determinado objetivo: o conhecimento bíblico necessário para se alcançar a vida eterna.

Ao desencadear uma operação fiduciária determinada pelo crer e pelo saber, essa cenografia apresenta uma constituição pautada através da conjunção de características do discurso religioso e pedagógico, dado que este último, de acordo com a definição de Orlandi (1996), também se constitui como um discurso autoritário. A aprendizagem escolar, concebida como meio de transmissão de informações e conhecimentos, pode ser relacionada com o curso de estudo bíblico preparado pela brochura $O$ que Deus requer de Nós como meio de ensino e propagação das verdades bíblicas da doutrina religiosa das TJ. A cena enunciativa de sala de aula se consolida. Os papéis enunciativos do enunciador, como aquele que ensina, e do enunciatário, como aquele que aprende, são projetados logo na abertura (contracapa da brochura). O enunciador, enquanto mediador entre a voz divina e o enunciatário (leitor), institui-se como detentor do saber, o responsável pela transmissão do saber sobre a divindade. Entretanto, o leitor não se configura como uma "tábula rasa". Ele é disposto em situação de simetria ou quase simetria de poderes e saberes.

O estilo da brochura é baseado em uma linguagem adaptada ao público pressuposto como feixe de expectativas a esse discurso. Assim, apresenta, fundamentalmente, como leitores pressupostos, aqueles que querem se iniciar nos mistérios da fé das TJ e se preparar pra receber o batismo, sendo, por conseguinte, admitidos a essa instituição religiosa. Esta 
brochura, dada à estrutura que a constitui, apresenta-se adequada ao leitor adulto que quer a facilitação do conhecimento da Palavra de Deus, da Palavra Revelada, e dos princípios e práticas requeridos por Deus aos verdadeiros cristãos.

\subsection{Lição 11- "Crenças e costumes que desagradam a Deus": Análise semiótica}

Tomemos para a nossa análise, agora, a lição 11 “Crenças e costumes que desagradam a Deus", extraída da brochura de estudo bíblico: O que Deus requer de nós, da totalidade discursiva das Testemunhas de Jeová.

\section{Lição 11}

Crenças e costumes que desagradam a Deus

Que crenças e costumes são errados? (1)

Devem os cristãos crer que Deus é uma Trindade? (2)

Por que não celebram os verdadeiros cristãos o Natal, a Páscoa moderna, nem

aniversários natalícios? $(3,4)$

Podem os mortos prejudicar os vivos? (5) Morreu Jesus numa cruz? (6)

Quão importante é agradar a Deus? (7) 
1. Nem todas as crenças e costumes são maus. Mas Deus não os aprova quando se originam de religião falsa ou são contrários a outros ensinos bíblicos. Mateus 15:6.

2. Trindade: É Jeová uma Trindade - três pessoas em um só Deus? Não! Jeová, o Pai, é "o único Deus verdadeiro". (João 17:3; Marcos 12:29) Jesus é Seu Filho primogênito e está sujeito a Deus. (1 Coríntios 11:3) O Pai é maior do que o Filho. (João 14:28) O espírito santo não é pessoa; é a força ativa de Deus. — Gênesis 1:2; Atos 2:18.

3. Natal e Páscoa: Jesus não nasceu em 25 de dezembro. Ele nasceu por volta de $1 .^{\circ}$ de outubro, época do ano em que os pastores mantinham seus rebanhos ao ar livre, à noite. (Lucas 2:8-12) Jesus nunca ordenou que os cristãos celebrassem seu nascimento. Antes, mandou que comemorassem ou recordassem sua morte. (Lucas 22:19, 20) O Natal e seus costumes originaram-se de antigas religiões falsas. O mesmo se dá com os costumes atuais da chamada Páscoa, tais como o uso de ovos e de coelhos. Os primeiros cristãos não celebravam nem o Natal, nem a Páscoa moderna, tampouco o fazem hoje em dia os verdadeiros cristãos.

4. Aniversários natalícios: Os únicos dois aniversários natalícios mencionados na Bíblia eram de pessoas que não adoravam a Jeová. (Gênesis 40:20-22; Marcos 6:21, 22, 24-27) Os primeiros cristãos não celebravam aniversários natalícios. $\mathrm{O}$ costume de celebrar natalícios originou-se das antigas religiões falsas. Os cristãos verdadeiros dão presentes e se divertem juntos em outras ocasiões do ano.

5. Medo dos mortos: Os mortos não podem fazer nem sentir nada. Não podemos ajudá-los, nem podem eles prejudicar-nos. (Salmo 146:4; Eclesiastes 9:5, 10) A alma morre; não continua viva após a morte. (Ezequiel 18:4) Mas às vezes anjos iníquos, chamados demônios, fingem ser espíritos de mortos. Os costumes que têm que ver com o medo ou a adoração dos mortos são errados. — Isaías 8:19.

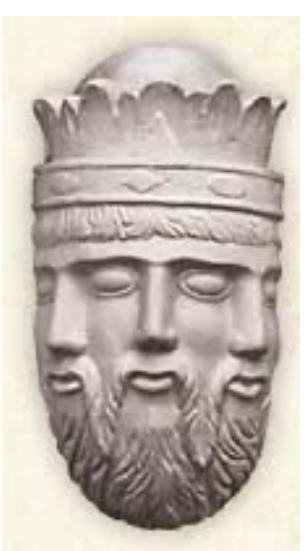

Deus não é uma Trindade

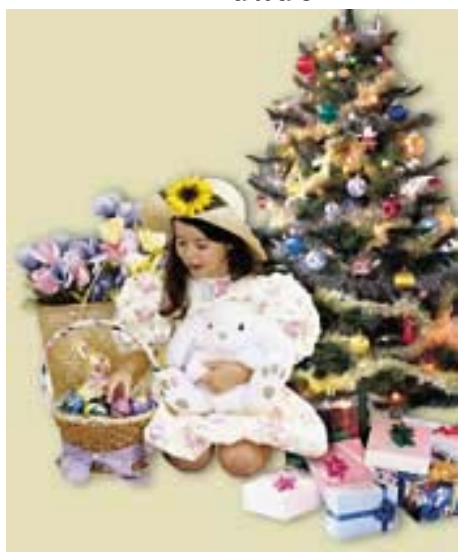

O Natal e a Páscoa moderna vêm de antigas religiões falsas

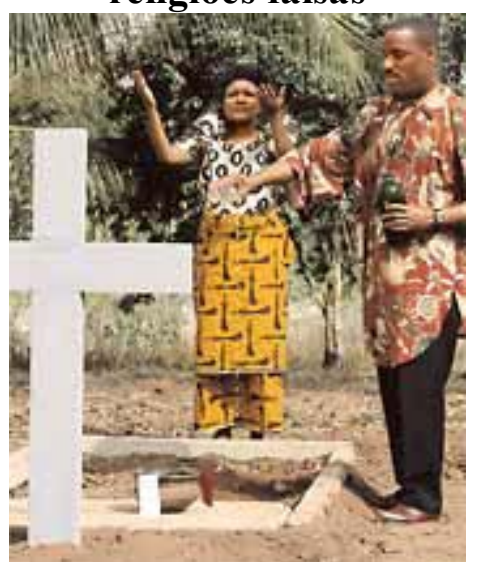

Não há nenhum motivo para adorar os mortos ou ter medo deles

6. A cruz: Jesus não morreu numa cruz. Ele morreu num poste, ou estaca. A palavra grega, em muitas Bíblias traduzida "cruz", refere-se apenas a um madeiro. O símbolo da cruz vem de antigas religiões falsas. Os primeiros cristãos não usavam nem adoravam a cruz. Portanto, você acha certo usar uma cruz na adoração? — Deuteronômio 7:26; 1 Coríntios 10:14.

7. Pode ser muito difícil abandonar algumas dessas crenças e costumes. Parentes e amigos talvez procurem convencê-lo a não mudar de crença. No entanto, agradar a Deus é mais importante do que agradar a homens. - Provérbios 29:25; Mateus 10:36, 37. 
Ilustração 46 O QUE DEUS requer de nós? São Paulo: Sociedade Torre de Vigia de Bíblias e Tratados, 1996. p.22-23.

O todo organizado de sentido do enunciado sincrético, de que se compõe a lição, é delimitado por espaços de não-sentido dos limites brancos a envolver a moldura, que fixa o olhar do enunciatário, estabelecendo com nitidez seu campo de visão.

A estrutura elementar, organização estrutural mínima que permeia o discurso da brochura de estudo bíblico $O$ que Deus Requer de Nós, pode ser estabelecida mediante a relação entre dois termos-objetos: humano (profano) vs. divino (sagrado).

Os termos categoriais são investidos axiologicamente da seguinte forma: o termo humano, pela não conformidade ao sistema de crenças e costumes das TJ, é investido de valor disfórico, e o termo divino, pela conformidade ao sistema de crenças vigente, é investido pelo valor eufórico. São disforizadas as práticas de crenças que permitem o domínio humano da religião falsa e euforizadas as práticas divinas dos primeiros cristãos e cristãos verdadeiros.

Nem todas as crenças e costumes são maus. Mas Deus não os aprova quando se originam de religião falsa ou são contrários a outros ensinos bíblicos. Mateus 15:6 (O QUE DEUS requer de nós, 1996, p. 22).

Os primeiros cristãos não celebravam nem o Natal, nem a Páscoa moderna, tampouco o fazem hoje em dia os verdadeiros cristãos (O QUE DEUS requer de nós, 1996, p. 22).

O costume de celebrar natalícios originou-se das antigas religiões falsas. Os cristãos verdadeiros dão presentes e se divertem juntos em outras ocasiões do ano (O QUE DEUS requer de nós, 1996, p. 23).

Os costumes que têm que ver com o medo ou a adoração dos mortos são errados. - Isaías 8:19 (O QUE DEUS requer de nós, 1996, p. 23).

Os primeiros cristãos não usavam nem adoravam a cruz. Portanto, você acha certo usar uma cruz na adoração? - Deuteronômio 7:26; 1 Coríntios 10:14 (O QUE DEUS requer de nós, 1996, p. 23).

Ao estabelecer uma sintaxe sumária, capaz de apreender as operações fundamentais que determinam essa lição, poderíamos definir para a posição $S_{1}$ o termo integração, no qual o 
cristão, convencido a mudar de crenças e costumes para agradar a Deus, é integrado ao sistema de valores proposto. Para a posição $\mathrm{S}_{2}$ podemos definir a posição de transgressão, na qual o sujeito constitui-se como transgressor dos valores propostos pelas TJ, pois, motivado por interesses humanos, apresenta dificuldade de abandonar suas crenças e costumes anteriores.

7. Pode ser muito difícil abandonar algumas dessas crenças e costumes. Parentes e amigos talvez procurem convencê-lo a não mudar de crença. No entanto, agradar a Deus é mais importante do que agradar a homens. Provérbios 29:25; Mateus 10:36, 37 (O QUE DEUS requer de nós, 1996, p. 23).

Vejamos como esses termos podem ser estabelecidos por meio do quadrado semiótico:

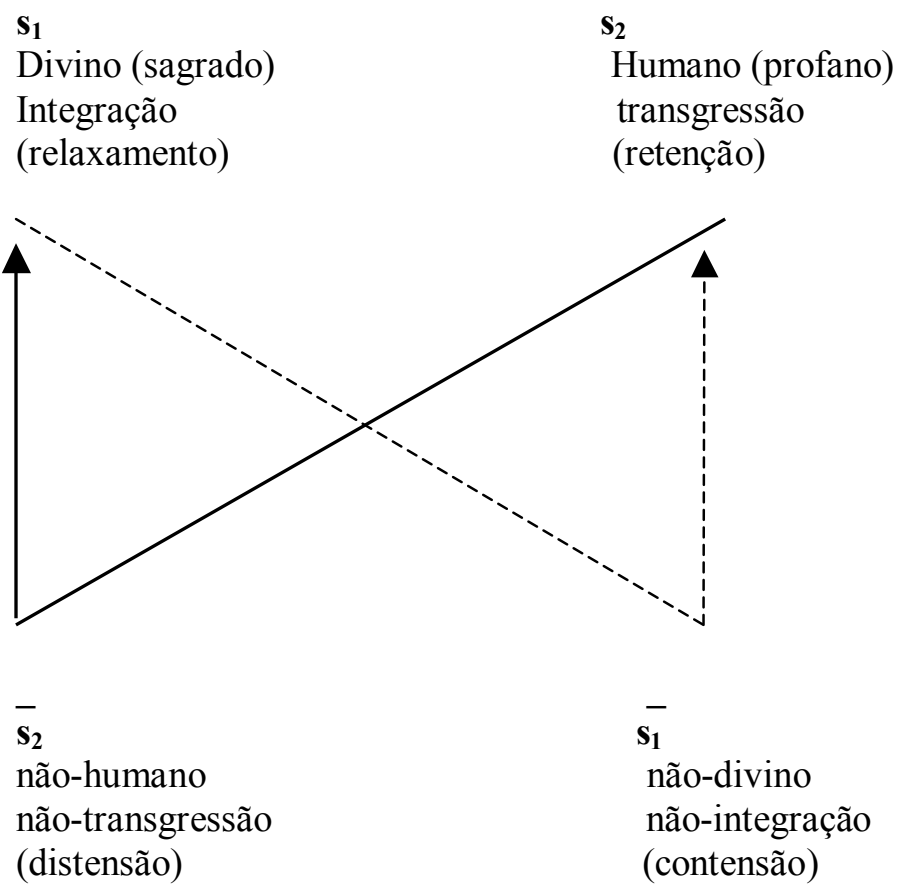

Para que o sujeito seja integrado ao sistema de valores proposto, determinado como o "verdadeiro", deve romper com seu contrato anterior, abandonando os ideais da religião “falsa”. Segundo Tatit (2003, p. 202): “a distensão propriamente dita instrui, no nível 
narrativo, o abandono dos antiprogramas desenvolvidos até então pelo sujeito e seu reingresso na rota desejada pelo destinador".

Desse modo, o sujeito realiza a parada da própria parada, responsável pelas condições tensivas do programa de manipulação anterior, para que possa ser integrado ao novo sistema de valores das TJ, com a determinação de uma nova continuidade (relaxamento), com a cifra da sanção positiva que integra o cristão com o $\mathrm{O}_{\mathrm{v}}$ "graça divina".

Podemos caracterizar o enunciado elementar da sintaxe narrativa que rege esse texto como a relação de conjunção do sujeito cristão com crenças e costumes originários de outros sistemas de valores, diferentes dos propugnados pelo universo ideológico das TJ. Desse modo, observamos o PN (programa narrativo) prévio do estabelecimento da relação conjuntiva do sujeito cristão com o objeto de valor $\left(\mathrm{O}_{\mathrm{v}}\right)$ "crenças e costumes que desagradam a Deus".

6. A cruz: Jesus não morreu numa cruz. Ele morreu num poste, ou estaca. A palavra grega, em muitas Bíblias traduzida "cruz", refere-se apenas a um madeiro. O símbolo da cruz vem de antigas religiões falsas. Os primeiros cristãos não usavam nem adoravam a cruz. Portanto, você acha certo usar uma cruz na adoração? - Deuteronômio 7:26; 1 Coríntios 10:14 (O QUE DEUS requer de nós, 1996, p. 23).

As crenças partilhadas pelo actante sujeito (cristão) são axiologizadas com o valor do repudiável e indesejável a esse sistema de valores, pois, de acordo com esse discurso, são originárias de religiões falsas, ou pertencentes a outros ensinos bíblicos.

Depreendemos a narrativa de transformação de estados do sujeito cristão, que inicialmente conjunto com o $\mathrm{O}_{\mathrm{v}}$ "crenças e costumes que desagradam a Deus", busca, por meio do estabelecimento de um programa de privação, renunciar o contrato anterior e, entrar em conjunção com o contrato vigente para pertencer ao sistema de valores proposto pelas TJ.

7. Pode ser muito difícil abandonar algumas dessas crenças e costumes. Parentes e amigos talvez procurem convencê-lo a não mudar de crença. No 
entanto, agradar a Deus é mais importante do que agradar a homens. Provérbios 29:25; Mateus 10:36, 37 (O QUE DEUS requer de nós, 1996, p. 23).

Ao tomar como base a narratividade imanente à primeira seqüência narrativa $\left(\mathrm{SN} 1_{1}\right)$, correspondente à enunciação enunciada, verificamos a presença de um programa narrativo (PN) de transformação de estados, em que $\mathrm{S}_{1}$ (destinador-manipulador) manipula $\mathrm{S}_{2}$ (destinatário-sujeito) a entrar em conjunção com o objeto valor $\left(\mathrm{O}_{\mathrm{v}}\right)$ "graça divina", por meio da aquisição do conhecimento das crenças e costumes que agradam a Deus e que conduzem o sujeito à salvação eterna.

$$
\begin{aligned}
& \mathrm{S}_{1} \rightarrow\left(\mathrm{S}_{2} \cup \mathrm{O}_{\mathrm{v}}\right) \rightarrow\left(\mathrm{S}_{2} \cap \mathrm{O}_{\mathrm{v}}\right) \\
& \mathrm{S}_{1}=\text { enunciador da brochura de estudo bíblico O que Deus Requer de Nós } \\
& \mathrm{S}_{2}=\text { cristão } \\
& \mathrm{O}_{\mathrm{v}}=\text { "graça divina" (conhecimento que conduz à salvação eterna) }
\end{aligned}
$$

O poder e autoridade conferidos ao enunciador da brochura de estudo bíblico, respaldados pelos valores das TJ e pelo caráter de autoridade da Palavra Revelada, fazem com que o enunciador da brochura $O$ que Deus Requer de Nós proceda à construção da lição do curso bíblico como um texto instrucional.

A brochura de estudo bíblico funciona como um PN de uso para que se obtenha o PN de base representado pela aquisição do $\mathrm{O}_{\mathrm{v}}$ "graça divina" (aquisição do conhecimento que conduz a salvação eterna). Podemos, desse modo, caracterizar o enunciado da brochura como um texto instrucional programador na medida em que possibilita a aquisição de uma competência: saber ser um verdadeiro cristão.

PN de base: $\mathrm{S}_{1} \rightarrow$ PN de uso [aceitar a doutrinação de um modo de vida cuja receita é dada no enunciado da brochura de estudo bíblico] 
A conjunção com o objeto-valor almejado ("graça divina") se realiza pelo PN de doação de competência estabelecido pelo destinador-manipulador.

O destinador-manipulador, enunciador da brochura instrucional (comentador), graças ao caráter de autoridade que lhe foi conferido, respaldado pelas referências bíblicas que utiliza na lição, dirige-se ao enunciatário-sujeito (leitor-aprendiz), através da construção do páthos negativo desse destinatário, pois disjunto dos princípios da fé, moral e prática dos "verdadeiros cristãos". Esse simulacro negativo do sujeito constitui-se, na lição considerada, pela instituição de perguntas retóricas no seu início, seguidas pela numeração dos parágrafos entre parênteses, nos quais se encontra desenvolvido no texto a explanação das respostas.

Para que esse enunciado obtenha êxito, é necessário que o destinatário-sujeito seja partidário do mesmo sistema de valores propostos pelo enunciador. Dessa forma, o destinador-manipulador, por meio da autoridade das Sagradas Escrituras, estabelece um contrato fiduciário, com a busca da adesão da imagem do enunciador pelo enunciatáriosujeito, que é modalizado para poder e saber examinar as verdades bíblicas.

O destinador-manipulador busca levar o enunciatário para que este adquira a competência esperada, e passe a ser integrado ao sistema de valores doutrinais das TJ. Analisamos esse fato como uma modalidade deôntica do dever-fazer (dever saber sobre o ser dos valores/ dever saber sobre o fazer) e de uma estrutura modal alética do dever-ser (necessidade), instaurada pelo destinador (dever agir como um verdadeiro cristão).

O destinador-manipulador estabelece um fazer cognitivo orientado para a atribuição da competência epistêmica do saber. O enunciatário é manipulado para dever-saber, querer-saber e crer-poder-saber entrar em conjunção com os valores ideológicos propostos no enunciado do curso de estudo bíblico. O destinador-manipulador, devido ao caráter coercitivo desse 
enunciado, estabelece uma manipulação por tentação e intimidação, determinando, conseqüentemente, a configuração patêmica do temor.

Assim, verificamos a presença da configuração passional de um sujeito regido pela agitação e pelo medo de não entrar em conjunção com o $\mathrm{O}_{\mathrm{v}}$ ("graça divina”). Tudo isso como o resultado do sujeito estar em conjunção com crenças "erradas".

1. Nem todas as crenças e costumes são maus. Mas Deus não os aprova quando se originam de religião falsa ou são contrários a outros ensinos bíblicos (O QUE Deus requer de nós, 1996, p. 22).

Tomemos inicialmente a dimensão contratual proposta por Greimas e Courtés (s.d, p. 84) e caracterizada como "o fato de estabelecer, de "contrair" uma relação intersubjetiva que tem por efeito modificar o estatuto (o ser e/ou o parecer) de cada um dos sujeitos em presença". Tendo essas definições em mente, observamos que esse enunciado é fundamentado mediante a dimensão cognitiva do discurso, pois ele se desenvolve em relação ao aumento do saber atribuído ao sujeito cristão (instalado no discurso). O fazer cognitivo do destinadormanipulador corresponde à transformação da relação do sujeito com o objeto saber (conhecimento que conduz a vida eterna).

A doação do saber é modalizada do ponto de vista veridictório, de tal modo que o enunciado de divulgação religiosa oferece parâmetros do parecer e ser cristão.

A figura emblemática e central do verdadeiro cristão é determinada pelas modalidades veridictórias, de forma que a imagem traçada para o enunciatário é daquele que parece e é cristão.

Os estados cognitivos (posições cognitivas) do verdadeiro cristão, obtidos graças ao jogo do ser e do parecer, possuem a seguinte articulação, no que diz respeito às modalidades veridictórias: verdadeiro/falso/secreto/mentiroso (GREIMAS; COURTÉS, s.d, p.488). 
verdade

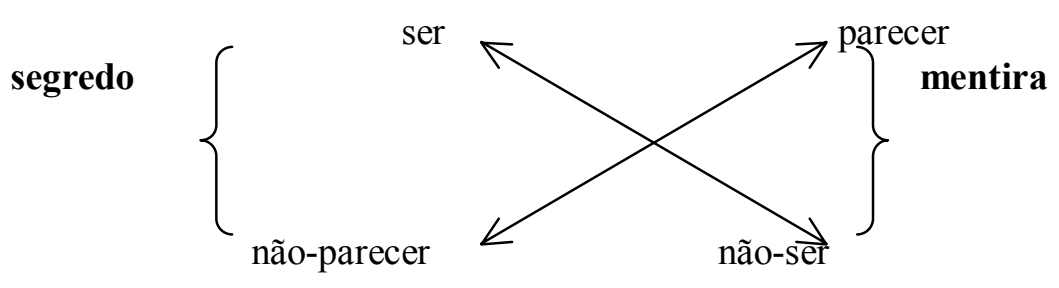

falsidade

O fazer persuasivo, aplicado pelo destinador-manipulador, procura fazer o sujeito manipulado crer no sistema de crenças, criado por um sistema de valores determinado. Tal criação desse sistema é, no entanto, motivada pelo fazer-parecer-verdadeiro. Desse modo, o sujeito do fazer procede ao estabelecimento de efeitos de verdade que buscam levar o enunciatário a crer nos valores e ideais por hora propostos, fazendo com que ele creia serem, tais valores, os verdadeiros. Todo o processo de fazer-crer, é importante ressaltar, se dá mediante uma performance cognitiva.

O enunciatário, por conseguinte, deve realizar um fazer interpretativo da manipulação exercida pelo destinador-manipulador (fazer-crer verdadeiro). Tal fazer interpretativo é realizado pelo julgamento epistêmico do crer. Dessa forma, ele deverá considerar os valores propostos como certamente verdadeiros: crer-ser (certeza) e parecer.

O destinatário-sujeito, desejoso dos valores cognitivos necessários para se tornar um verdadeiro-cristão, quer-saber entrar em conjunção com esses valores e se integrar a eles.

O sujeito, contudo, ao realizar a performance cognitiva da decisão de se integrar ao sistema de valores, recebe do destinador a sanção cognitiva de reconhecimento, na qual o sujeito é julgado como cumpridor do contrato e pertencente ao sistema de restrições semânticas proposto. 
As estruturas narrativas convertem-se em discurso graças às escolhas efetuadas pelo sujeito da enunciação. Escolhas estas realizadas mediante os efeitos de sentido que deseja obter. No que diz respeito ao nível discursivo, abordaremos nessa seção a sintaxe discursiva da brochura considerada, vista em seus dois aspectos: a) projeção da instância da enunciação no enunciado (projeção das categorias de pessoa, tempo e espaço) e b) relações argumentativas entre enunciador e enunciatário. Daremos destaque aos mecanismos argumentativos que o enunciador da brochura utiliza, pois ela tem como finalidade principal, sendo um texto instrucional de divulgação religiosa, persuadir e convencer seu enunciatário da veracidade do sistema de valores das TJ por oposição aos valores partilhados por outros sistemas de valores "cristãos".

Inicialmente, tomaremos como base a categoria de pessoa. Notamos a utilização de uma debreagem enunciativa de primeiro grau. O narrador conversa, enceta um diálogo com o leitor. O narrador pergunta e ele mesmo responde, o que configura, portanto, um fenômeno de enunciação enunciada.

\section{Que crenças e costumes são errados? (1)}

1. Nem todas as crenças e costumes são maus. Mas Deus não os aprova quando se originam de religião falsa ou são contrários a outros ensinos bíblicos. — Mateus 15:6. (O QUE DEUS requer de nós, 1996, p. 22)

O entrelaçamento diagramático, dado no plano de expressão (PE) pela associação das questões introdutórias com as explanações ao longo do texto da brochura, simula um jogo de vozes que instaura no enunciado um "eu" narrador e um "tu” narratário.

Esse jogo de vozes, determinado pelo simulacro dialógico, no qual um "eu" que pergunta se dirige a um "tu" que responde, consolida a cena enunciativa de sala de aula, determinada pela lição da brochura de estudo bíblico. A utilização desse mecanismo de projeção dos actantes da enunciação, por meio da instauração de perguntas e respostas (P-R), apresenta um efeito de sentido de realidade ou de referente, pois se cria um efeito de verdade 
com a ilusão de uma situação "real" de interação conversacional empregada no curso de estudo bíblico. A utilização de perguntas (questões introdutórias à lição) constitui uma forma de manipulação do enunciador, uma maneira de fazer com que a informação seja dada. A resposta, condicionada pelas explanações ao longo do texto, institui-se como afirmação de um saber por parte do enunciador.

Verificamos também a presença de perguntas retóricas instaladas no enunciado:

É Jeová uma Trindade - três pessoas em um só Deus? Não! Jeová, o Pai, é “o único Deus verdadeiro" (O QUE DEUS requer de nós, 1996, p. 22).

Portanto, você acha certo usar uma cruz na adoração? - Deuteronômio 7:26; 1 Coríntios 10:14 (O QUE DEUS requer de nós, 1996, p. 23).(grifo nosso)

De acordo com Discini (2005a, p. 340), o enunciador por meio da utilização da pergunta retórica, "não necessita saber a resposta do leitor, pois a resposta é dada implicitamente no próprio texto". Desse modo, a pergunta retórica "define-se como meio para a construção da imagem positiva do leitor: aquele que é e sabe que é o legítimo participante da cena enunciativa" (DISCINI: 2005a, p. 340).

Esse efeito de sentido cria um simulacro de subjetividade, com uma maior aproximação entre o leitor-aprendiz e o enunciador da brochura instrucional.

No que diz respeito à categoria temporal presente no enunciado da brochura, verificamos a presença do presente omnitemporal ou gnômico, caracterizado por apresentar um momento de referência e um momento do acontecimento ilimitados. Essa categoria temporal, utilizada "para enunciar verdades eternas ou que se pretendem como tais" (FIORIN, 2002, p. 151), presentifica-se pelas explanações e explicações, das quais se constitui o enunciado da brochura.

2. Trindade: É Jeová uma Trindade - três pessoas em um só Deus? Não! Jeová, o Pai, é “o único Deus verdadeiro”. (João 17:3; Marcos 12:29) Jesus é 
Seu Filho primogênito e está sujeito a Deus. (1 Coríntios 11:3) O Pai é maior do que o Filho. (João 14:28) O espírito santo não é pessoa; é a força ativa de Deus. — Gênesis 1:2; Atos 2:18. (O QUE DEUS requer de nós, 1996, p. 23).

A espacialização, da qual este texto se serve, situa-se em uma dimensão do aqui sempre implícito e de extensão ilimitada. Dessa forma, "tanto o que é dito como o sujeito do dizer pertencem a todo e qualquer lugar" (DISCINI, 2006b, p. 164). O espaço enunciativo indeterminado, associado à utilização do presente omnitemporal e à generalização dos atores da enunciação, confirma e viabiliza a construção de um discurso voltado a todas as pessoas, em quaisquer lugar e época histórica, estratégia recorrente aos discursos de divulgação religiosa.

Por causa da incompatibilidade de saberes entre enunciador e enunciatário, simula-se a cena enunciativa de doação de saber entre o enunciador da brochura de estudo bíblico e o leitor aprendiz. Desse modo, podemos nos interrogar sobre qual é a natureza desse saber e quais são os efeitos argumentativos utilizados pelo enunciador para instituir o efeito de sentido de verdade?

Tomaremos, por princípio, que a estruturação do saber depende da orientação determinada pelo olhar humano: "voltado para o mundo, o olhar tende a descrever esse mundo com as categorias do conhecimento; mas, voltado para si mesmo, o olhar tende a construir categorias de crença" (CHARAUDEAU, 2006, p. 43).

Assim, verificamos que os saberes operacionalizados por esse enunciado pertencem à categoria dos saberes de crença.

As crenças dão conta do mundo quanto à maneira de proceder à regulação das práticas sociais, ao se criarem normas efetivas de comportamento, e também quanto aos discursos de representação produzidos no âmbito do grupo social, para avaliar esses comportamentos, criando-se, assim, normas ideais. Estas apontam não apenas para os imaginários de referência dos comportamentos (o que se deveria fazer ou não fazer), mas também para os imaginários de justificativa desses procedimentos (se é do bem ou do mal) (CHARAUDEAU, 2006, p. 46). 
Por meio da instauração dessa cena enunciativa, o enunciador transmite o saber, caracterizado pela modalidade veridictória como o "saber verdadeiro", por oposição ao considerado "falso" pelo julgamento do enunciador. A lição instrucional, ao operar com a dimensão da enunciação informativa dos saberes de crença, pretende fazer com que o interlocutário partilhe os julgamentos negativos que estabelece em relação às crenças e costumes considerados errôneos e falsos, pois eles são originários de "religião falsa ou contrários a outros ensinos bíblicos" (O QUE DEUS requer de nós, 1996, p. 22).

Desse modo, o enunciador força o enunciatário a tomar uma posição com relação ao saber que lhe foi transmitido, com a posterior adesão ao sistema de valores proposto. Assim, o enunciatário, tendo realizado a adesão ao sistema de valores proposto, deveria efetuar a passagem do saber considerado "errôneo" ao saber "correto".

Esse efeito de sentido de verdade, do dizer-verdadeiro, é construído no enunciado considerado mediante a utilização de dois recursos argumentativos: a citação de autoridade e o argumento por ilustração.

Observemos inicialmente como se desenvolve no enunciado o mecanismo argumentativo de citação de autoridade.

Vejamos como Maingueneau (1997, p. 100) procede à definição do argumento de autoridade:

Geralmente, tratam-se de enunciados já conhecidos por uma coletividade, que gozam o privilégio da intangibilidade: por essência, não podem ser resumidos nem reformulados, constituem a própria Palavra, captada em sua fonte (MAINGUENEAU, 1997, p. 100).

A autoridade da Bíblia é invocada a todo o momento, de tal modo que citações e referências bíblicas permeiam todo o enunciado da lição instrucional. 


\section{Lição 11 \\ Crenças e costumes que desagradam a Deus}

Que crenças e costumes são errados? (1)

Devem os cristãos crer que Deus é uma Trindade? (2)

Por que não celebram os verdadeiros cristãos o Natal, a Páscoa moderna, nem aniversários natalícios? $(3,4)$

Podem os mortos prejudicar os vivos? (5) Morreu Jesus numa cruz? (6)

Quão importante é agradar a Deus? (7)

1. Nem todas as crenças e costumes são maus. Mas Deus não os aprova quando se originam de religião falsa ou são contrários a outros ensinos bíblicos. - Mateus 15:6.

2. Trindade: É Jeová uma Trindade - três pessoas em um só Deus? Não! Jeová, o Pai, é "o único Deus verdadeiro". (João 17:3; Marcos 12:29) Jesus é Seu Filho primogênito e está sujeito a Deus. (1 Coríntios 11:3) O Pai é maior do que o Filho. (João 14:28) O espírito santo não é pessoa; é a força ativa de Deus. - Gênesis 1:2; Atos 2:18.

3. Natal e Páscoa: Jesus não nasceu em 25 de dezembro. Ele nasceu por volta de $1 .^{\circ}$ de outubro, época do ano em que os pastores mantinham seus rebanhos ao ar livre, à noite. (Lucas 2:8-12) Jesus nunca ordenou que os cristãos celebrassem seu nascimento. Antes, mandou que comemorassem ou recordassem sua morte. (Lucas 22:19, 20) O Natal e seus costumes originaram-se de antigas religiões falsas. $\mathrm{O}$ mesmo se dá com os costumes atuais da chamada Páscoa, tais como o uso de ovos e de coelhos. Os primeiros cristãos não celebravam nem o Natal, nem a Páscoa moderna, tampouco o fazem hoje em dia os verdadeiros cristãos.

4. Aniversários natalícios: Os únicos dois aniversários natalícios mencionados na Bíblia eram de pessoas que não adoravam a Jeová. (Gênesis 40:20-22; Marcos 6:21, 22, 24-27) Os primeiros cristãos não celebravam aniversários natalícios. O costume de celebrar natalícios originou-se das antigas religiões falsas. Os cristãos verdadeiros dão presentes e se divertem juntos em outras ocasiões do ano.

5. Medo dos mortos: Os mortos não podem fazer nem sentir nada. Não podemos ajudá-los, nem podem eles prejudicar-nos. (Salmo 146:4; Eclesiastes 9:5, 10) A alma morre; não continua viva após a morte. (Ezequiel 18:4) Mas às vezes anjos iníquos, chamados demônios, fingem ser espíritos de mortos. Os costumes que têm que ver com o medo ou a adoração dos mortos são errados. - Isaías 8:19.

6. A cruz: Jesus não morreu numa cruz. Ele morreu num poste, ou estaca. A palavra grega, em muitas Bíblias traduzida "cruz", refere-se apenas a um madeiro. O símbolo da cruz vem de antigas religiões falsas. Os primeiros cristãos não usavam nem adoravam a cruz. Portanto, você acha certo usar uma cruz na adoração? - Deuteronômio 7:26; 1 Coríntios 10:14.

7. Pode ser muito difícil abandonar algumas dessas crenças e costumes. Parentes e amigos talvez procurem convencê-lo a não mudar de crença. No entanto, agradar a Deus é mais importante do que agradar a homens. Provérbios 29:25; Mateus 10:36, 37.

(O QUE DEUS requer de nós, 1996, p. 22-23) (grifo nosso). 
Por meio do recurso argumentativo da citação de autoridade, o enunciador garante a verossimilhança de seu dizer e a desqualificação do sistema de crenças de seu adversário. O enunciador desqualifica o dizer de seu adversário ao atacar o conteúdo do "Outro" que é afirmado no enunciado, demonstrando que as crenças apresentadas (trindade natal, páscoa, aniversários natalícios, adoração dos mortos e da cruz) são provenientes de uma interpretação incorreta das fontes bíblicas, tidas como verdades inquestionáveis desse sistema de valores.

Outro procedimento argumentativo empregado como prova da veracidade de seu dizer é a ilustração. De acordo com Fiorin (2005a, p. 75), "no procedimento de ilustração, o narrador enuncia uma afirmação geral e dá exemplos com a finalidade de comprová-la”.

Enquanto o exemplo era incumbido de fundamentar a regra, a ilustração tem a função de reforçar a adesão a uma regra conhecida e aceita, fornecendo casos particulares que esclarecem o enunciado geral, mostram o interesse deste através da variedade de aplicações possíveis, aumentam-lhe a presença na consciência (PERELMAN; OLBRECHTS-TYTECA, 2005, p. 407).

Examinemos o procedimento argumentativo de ilustração, que se desenvolve na lição instrucional:

3. Natal e Páscoa: Jesus não nasceu em 25 de dezembro. Ele nasceu por volta de $1 .^{\circ}$ de outubro, época do ano em que os pastores mantinham seus rebanhos ao ar livre, à noite. (Lucas 2:8-12) Jesus nunca ordenou que os cristãos celebrassem seu nascimento. Antes, mandou que comemorassem ou recordassem sua morte. (Lucas 22:19,20) O Natal e seus costumes originaram-se de antigas religiões falsas. $\mathrm{O}$ mesmo se dá com os costumes atuais da chamada Páscoa, tais como o uso de ovos e de coelhos. Os primeiros cristãos não celebravam nem o Natal, nem a Páscoa moderna, tampouco o fazem hoje em dia os verdadeiros cristãos (O QUE DEUS requer de nós, 1996, p. 22).

Por meio desse trecho observamos que o enunciador enuncia uma verdade geral, dada por meio da negação do marco referencial natalício: "Jesus não nasceu em 25 de dezembro". Em seguida, o enunciador realiza sua explanação por meio de relatos de casos particulares que comprovam a verdade geral enunciada, invocados por intermédio da autoridade das Sagradas 
Escrituras. Desse modo, o enunciado constrói a referência ao que seria considerado o "verdadeiro marco referencial natalício: a data de $1^{\circ}$. de outubro: "Ele nasceu por volta de $1 .^{\circ}$ de outubro, época do ano em que os pastores mantinham seus rebanhos ao ar livre, à noite (Lucas 2:8-12)" (O QUE DEUS requer de nós, 1996, p. 22).

\footnotetext{
${ }^{8}$ Havia também no mesmo país pastores vivendo ao ar livre e mantendo de noite vigílias sobre os seus rebanhos. ${ }^{9}$ E, repentinamente estava parado ao lado deles o anjo de Jeová, e a glória de Jeová reluzia em volta deles, e ficaram muito temerosos. ${ }^{10}$ Mas o anjo disse-lhes: "Não temais, pois, eis que vos declaro boas novas duma grande alegria que todo o povo terá, ${ }^{11}$ porque hoje vos nasceu na cidade de Davi um Salvador, que é Cristo, [o] Senhor. ${ }^{12} \mathrm{E}$ este é um sinal para vós: achareis uma criança enfaixada $\mathrm{e}$ deitada numa manjedoura (Lucas 2:8-12) (TRADUÇÃO do Novo Mundo das Escrituras Sagradas, 1992, p. 1284) ${ }^{17}$.
}

O emprego do caso particular comprova a verdade geral enunciada, de modo a não se admitir questionamentos. Verificamos também a presença da argumentação pelo exemplo, pois os "primeiros cristãos", por não celebrarem nem o Natal e nem a Páscoa moderna, por não celebrarem natalícios e por não se utilizarem da adoração da cruz, são tomados como modelos de conduta a serem imitados pelos verdadeiros cristãos.

Constatamos quais os procedimentos argumentativos empregados pelo enunciador para convencer e persuadir o enunciatário de sua veracidade. Entretanto, uma questão ainda permanece em aberto: quais os procedimentos argumentativos empregados pelo enunciador para refutar o discurso de seu adversário e determiná-lo como falso e mentiroso?

Se o recurso verbal, caracterizado pela utilização de um mecanismo argumentativo baseado no estabelecimento de perguntas e respostas, produz um efeito de sentido de aproximação e de ilusão do real, graças à simulação de uma cena enunciativa de sala de aula, como podemos configurar o efeito de sentido determinado pela instauração do visual no texto?

\footnotetext{
${ }^{17}$ As referências bíblicas da TJ referem-se à TRADUÇÃO do Novo Mundo das Escrituras Sagradas. São Paulo: Sociedade Torre de Vigia de Bíblias e Tratados, 1986.
} 
Reproduzimos a seguir as fotografias que acompanham a lição considerada:

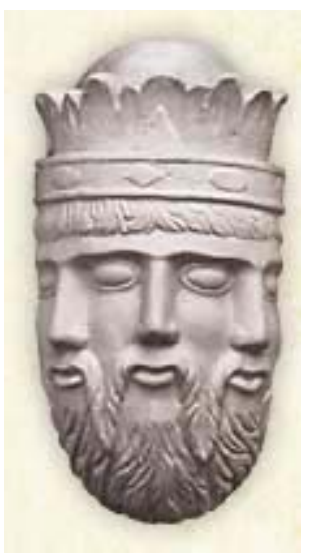

Ilustração 47 Deus não é uma trindade

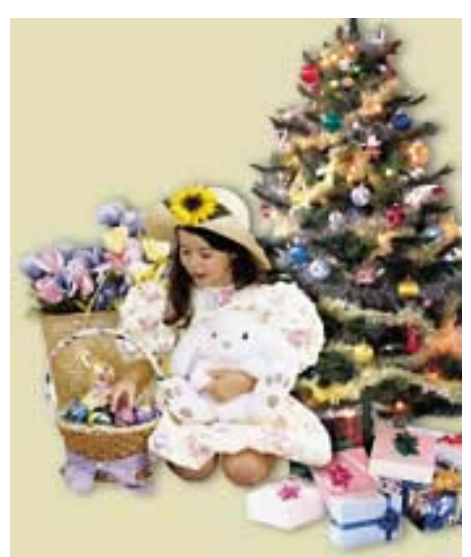

Ilustração 48 O Natal e a Páscoa moderna vêm de antigas religiões falsas

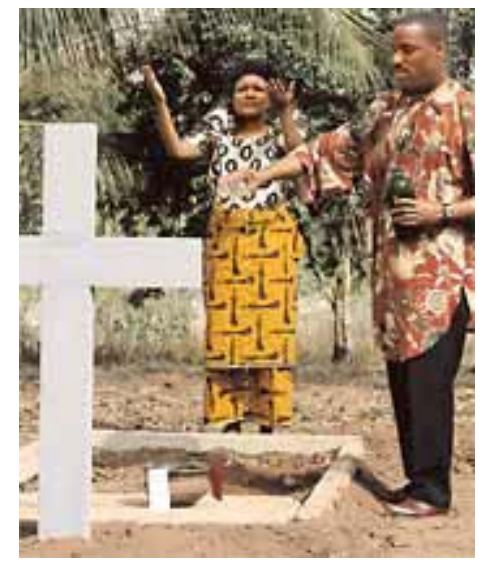

Ilustração 49 Não há nenhum motivo para adorar os mortos ou ter medo deles

A utilização das fotografias, asseguradas pelo seu papel ancorador e ideológicocultural de "cópia do real", produz um efeito de sentido de objetividade, determinado por 
meio da ilusão de referente ou realidade estabelecidos no enunciado. As fotografias empregadas possuem função utilitária:

A função utilitária dos textos se fundamenta na exposição, desenvolvimento e elucidação de idéias que, manifestadas denotativamente, permitem ao leitor atravessar o plano da expressão e ir direto ao plano do conteúdo (DISCINI, 2005a, p. 340).

O emprego das fotografias em função utilitária, que permeia o enunciado instrucional, graças ao efeito de sentido de afastamento, permite com que o enunciador evite arcar com a responsabilidade do que é dito, já que o sistema de crenças do "outro" (catolicismo e umbanda), ao qual se atribui um julgamento negativo, ressoa em outro sistema de significação axiológica, por oposição ao caráter da totalidade TJ.

$\mathrm{Na}$ semântica discursiva, os valores pertencentes ao sistema ideológico das TJ, já atualizados pelo sujeito narrativo, são revestidos com o valor do desejável e assimilados como algo do "bem", por oposição aos valores partilhados por outras crenças religiosas, revestidos pelo valor do indesejável e assimilados como algo do "mal".

Desse modo, tomamos como base a noção de que o fundamento ideológico do discurso é reconstruído pela ressemantização de temas, com a sua posterior conversão figurativa.

Vejamos como se constroem os procedimentos de tematização e figurativização inerentes à brochura de estudo bíblico considerada.

Tomemos como base exemplos de temas e figuras extraídos do enunciado verbal da brochura que remetem às construções contraditórias de mundo, de modo a se configurarem em uma totalidade (Testemunha de Jeová) a negação de seu contrário (Catolicismo).

Assim, observamos também a presença da negação dos seguintes temas, pertencentes ao discurso católico, no enunciado instrucional considerado:

a) necessidade de celebração da solenidade da santíssima trindade: a trindade de Deus: 
Trindade: É Jeová uma Trindade - três pessoas em um só Deus? Não! Jeová, o Pai, é "o único Deus verdadeiro" (O QUE DEUS requer de nós, 1996, p. 22).

b) necessidade de celebração do natal e da páscoa:

O Natal e seus costumes originaram-se de antigas religiões falsas. O mesmo se dá com os costumes atuais da chamada Páscoa, tais como o uso de ovos e de coelhos. Os primeiros cristãos não celebravam nem o Natal, nem a Páscoa moderna, tampouco o fazem hoje em dia os verdadeiros cristãos (O QUE DEUS requer de nós, 1996, p. 22).

c) necessidade de celebração de aniversários natalícios:

O costume de celebrar natalícios originou-se das antigas religiões falsas. Os cristãos verdadeiros dão presentes e se divertem juntos em outras ocasiões do ano (O QUE DEUS requer de nós, 1996, p. 23).

d) reverência aos mortos: (Finados):

Os costumes que têm que ver com o medo ou a adoração dos mortos são errados (O QUE DEUS requer de nós, 1996, p. 23).

e) a reverência à cruz com seu poder simbólico: exaltação da santa cruz:

O símbolo da cruz vem de antigas religiões falsas. Os primeiros cristãos não usavam nem adoravam a cruz. Portanto, você acha certo usar uma cruz na adoração? (O QUE DEUS requer de nós, 1996, p. 23).

Vejamos como o discurso do catecismo católico tematiza e figurativiza as verdades contraditórias às propugnadas pelas TJ. Examinaremos o discurso do Compêndio do Catecismo da Igreja Católica.

a) necessidade de celebração da solenidade da santíssima trindade: a trindade de Deus: 
48. Como a Igreja exprime a sua fé trinitária?

A Igreja exprime a sua fé trinitária ao confessar um só Deus em três Pessoas: Pai, Filho e Espírito Santo. As três Pessoas divinas são um só Deus porque cada uma delas é idêntica à plenitude da única e indivisível natureza divina. Elas são realmente distintas entre si pelas relações que as põe em referência umas com as outras: o Pai gera o Filho, o Filho é gerado pelo Pai, o Espírito Santo procede do Pai e do Filho (BENTO XVI, 2005, p. 36).

b) necessidade de celebração do natal e da páscoa:

103. O que ensina o Evangelho sobre os Mistérios do nascimento e da infância de Jesus?

No Natal, a glória do Céu se manifesta na fraqueza de uma criança; a circuncisão de Jesus é sinal e sua inserção no povo hebraico e prefiguração do nosso Batismo; a Epifania é a manifestação do Rei-Messias de Israel a todas as nações, na sua apresentação no templo, em Simeão e Ana é toda a espera de Israel que vem ao encontro do seu Salvador; a fuga para o Egito e a matança dos inocentes anunciam que toda a vida de Cristo estará sob o sinal da perseguição; a sua volta do Egito lembra o Êxodo e apresenta Jesus como o novo Moisés; ele é o verdadeiro e definitivo libertador (BENTO XVI, 2005, p. 48).

\section{Qual é o centro do tempo litúrgico?}

O centro do tempo litúrgico é o domingo, fundamento e núcleo de todo o ano litúrgico, que tem o seu ápice na Páscoa anual, a festa das festas (BENTO XVI, 2005, p. 84).

c) reverência aos mortos: (Finados):

\section{O que exprimem os funerais?}

Os funerais, embora celebrados segundo diferentes ritos correspondentes às situações e às tradições de cada região, exprimem o caráter pascal da morte cristã na esperança da ressurreição, e o sentido da comunhão com o defunto particularmente mediante a oração e a purificação da sua alma (BENTO XVI, 2005, p. 1110-111).

d) reverência à cruz com seu poder simbólico: exaltação da santa cruz:

280. Em que sentido a Eucaristia é memorial do sacrifício de Cristo? A Eucaristia é memorial no sentido de que torna presente e atual o sacrifício que Cristo ofereceu ao Pai na cruz, uma vez por todas, em favor da humanidade. O caráter sacrificial da Eucaristia se manifesta nas próprias palavras da instituição: "Isto é o meu corpo que é dado por vós" e "Este 
cálice é a nova aliança no meu sangue, que é derramado por vós" (Lc 22, 1920). O sacrifício da cruz e o sacrifício da Eucaristia são um único sacrifício. Idênticos são a vítima e o oferente, diferente é apenas o modo de oferecer: cruento na cruz, incruento na Eucaristia (BENTO XVI, 2005, p. 94).

Vejamos como esses percursos temáticos do discurso católico de divulgação religiosa, refutados pelo sistema de valores das $\mathrm{TJ}$, recebem um revestimento figurativo próprio, concretizado por meio de duas semióticas, verbal e visual (fotografias), de modo a se considerar a presença de dois percursos figurativos conflitantes: o percurso figurativo do falso e do verdadeiro cristão.

\section{Discurso (TJ.) de divulgação religiosa \\ Percursos Figurativos}

\section{O Verdadeiro Cristão}

- Jeová, o pai como "o único Deus verdadeiro".O pai é maior do que o filho. O Espírito Santo como força ativa de Deus;

- Marco referencial natalício: $1^{\circ}$. de outubro;

- Ausência de celebração da Páscoa e Natal;

- Ausência de celebração de aniversários natalícios;

- Ausência de exaltação da santa Cruz - A alma morre, não continua viva após a morte.

\section{O Falso Cristão}

- Trindade: Pai equivalente ao Filho e ao Espírito Santo;

- Marco referencial natalício: 25 de dezembro;

- Símbolos pascais: ovos de Páscoa, Coelhos; 
- Aniversários natalícios;

- Adoração do símbolo da cruz;

- A vida é um dom de Deus e a morte não a pode sufocar.

A análise dos mecanismos de tematização e figurativização demonstra ainda que a negação de seu contrário está contida no próprio texto. Os temas e figuras católicos, reportados no enunciado instrucional da brochura $O$ que Deus Requer de Nós, são negados, atravessados pela exclusão. O catolicismo é dado como o discurso renegado, de tal modo que se demonstra, através da argumentação verbal, a não convergência entre os dogmas católicos e o enunciado adversário. Para legitimar o caráter de autoridade do texto considerado, invocase continuamente a autoridade da Sagrada Escritura. Entretanto, a citação da autoridade da Sagrada Escritura só é aceitável no círculo do mesmo, devido à submissão ao sistema de restrições de sua própria formação discursiva. Para não se colocar em contradição, o enunciado opera com o estabelecimento de uma triagem de citações, a fim de convocar apenas os fragmentos da Bíblia que estariam de acordo com o sentido do sistema de restrições do enunciador da brochura instrucional.

1. Nem todas as crenças e costumes são maus. Mas Deus não os aprova quando se originam de religião falsa ou são contrários a outros ensinos bíblicos. - Mateus 15:6.

2. Trindade: É Jeová uma Trindade - três pessoas em um só Deus? Não! Jeová, o Pai, é "o único Deus verdadeiro". (João 17:3; Marcos 12:29) Jesus é Seu Filho primogênito e está sujeito a Deus. (1 Coríntios 11:3) O Pai é maior do que o Filho. (João 14:28) O espírito santo não é pessoa; é a força ativa de Deus. - Gênesis 1:2; Atos 2:18.

3. Natal e Páscoa: Jesus não nasceu em 25 de dezembro. Ele nasceu por volta de $1 .^{\circ}$ de outubro, época do ano em que os pastores mantinham seus rebanhos ao ar livre, à noite. (Lucas 2:8-12) Jesus nunca ordenou que os cristãos celebrassem seu nascimento. Antes, mandou que comemorassem ou recordassem sua morte. (Lucas 22:19, 20) O Natal e seus costumes originaram-se de antigas religiões falsas. $\mathrm{O}$ mesmo se dá com os costumes atuais da chamada Páscoa, tais como o uso de ovos e de coelhos. Os 
primeiros cristãos não celebravam nem o Natal, nem a Páscoa moderna, tampouco o fazem hoje em dia os verdadeiros cristãos.

4. Aniversários natalícios: Os únicos dois aniversários natalícios mencionados na Bíblia eram de pessoas que não adoravam a Jeová. (Gênesis 40:20-22; Marcos 6:21, 22, 24-27) Os primeiros cristãos não celebravam aniversários natalícios. O costume de celebrar natalícios originou-se das antigas religiões falsas. Os cristãos verdadeiros dão presentes e se divertem juntos em outras ocasiões do ano.

5. Medo dos mortos: Os mortos não podem fazer nem sentir nada. Não podemos ajudá-los, nem podem eles prejudicar-nos. (Salmo 146:4; Eclesiastes 9:5, 10) A alma morre; não continua viva após a morte. (Ezequiel 18:4) Mas às vezes anjos iníquos, chamados demônios, fingem ser espíritos de mortos. Os costumes que têm que ver com o medo ou a adoração dos mortos são errados. - Isaías 8:19.

6. A cruz: Jesus não morreu numa cruz. Ele morreu num poste, ou estaca. A palavra grega, em muitas Bíblias traduzida "cruz", refere-se apenas a um madeiro. O símbolo da cruz vem de antigas religiões falsas. Os primeiros cristãos não usavam nem adoravam a cruz. Portanto, você acha certo usar uma cruz na adoração? - Deuteronômio 7:26; 1 Coríntios 10:14.

7. Pode ser muito difícil abandonar algumas dessas crenças e costumes. Parentes e amigos talvez procurem convencê-lo a não mudar de crença. No entanto, agradar a Deus é mais importante do que agradar a homens. Provérbios 29:25; Mateus 10:36, 37.

(O QUE DEUS requer de nós, 1996, p. 22-23) (grifo nosso)

A citação dos temas do Outro (Catolicismo) apresenta um papel crucial, pois, pela utilização da referência bíblica, afirma-se no enunciado a inexatidão das informações do discurso adversário. O modo de polemizar do enunciador da brochura se dá pela instauração do seu "Outro", considerado desqualificado, pois este "Outro" fornece informações incongruentes com os ensinamentos bíblicos, dentro da visão da formação ideológica das TJ.

No que diz respeito ao enunciado visual da lição, consideremos inicialmente as proposições estabelecidas por Barthes (1984), no que concerne às funções da mensagem lingüística em relação à mensagem icônica. Para Barthes (1984) a mensagem icônica pode designar a função de ancoragem ou etapa.

A unidade textual recortada para análise (Lição 11) apresenta o enunciado verbal em função de ancoragem, ao tomarmos a terminologia de Barthes (1984). O visual sincretizado ao verbal, no gênero compêndio didático de estudo bíblico da TJ, é discursivizado como expansão das figuras verbais, apresentando, portanto, o icônico em uma relação de 
completude com o verbal, o que viabiliza a leitura linear e facilitada, própria ao tom professoral, que permeia a brochura de estudo bíblico.

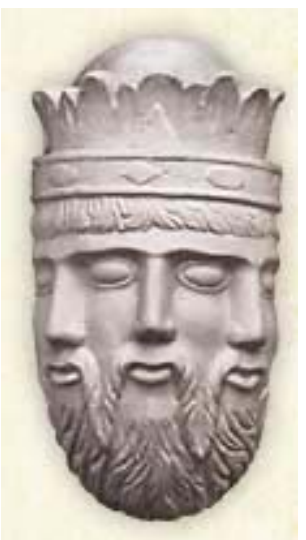

Ilustração 50 Deus não é uma trindade

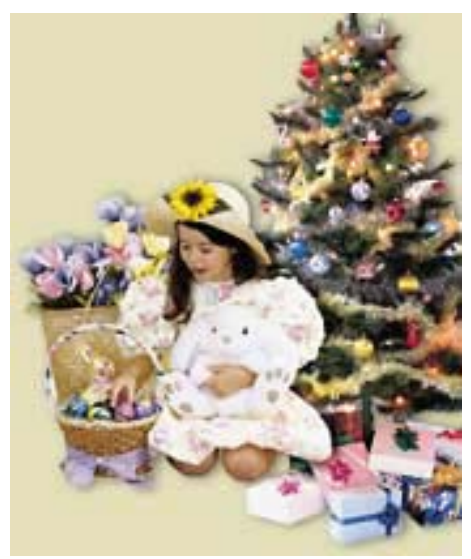

Ilustração 51 O Natal e a Páscoa moderna vêm de antigas religiões falsas

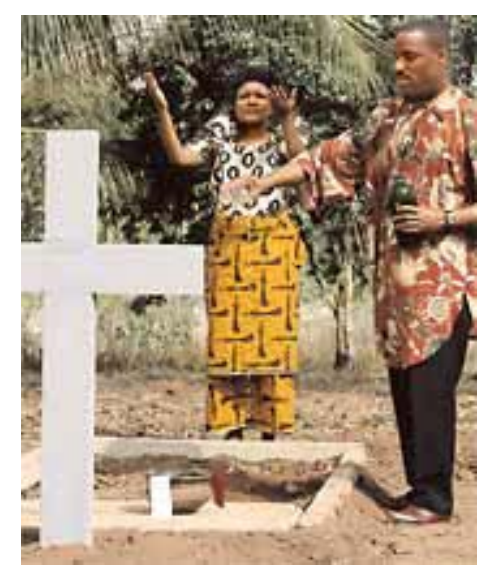

Ilustração 52 Não há nenhum motivo para adorar os mortos ou ter medo deles

As fotografias que aludem aos temas do discurso católico (a trindade de Deus, a necessidade de celebração do Natal e da páscoa, a reverência aos mortos e a reverência à cruz 
com seu poder simbólico) ganham um novo sentido quando verificamos que os temas e figuras contemplados remetem a construções contraditórias de mundo, de modo a se configurar em uma totalidade (Testemunha de Jeová) a negação de seu contrário (Catolicismo).

A ilustração 28 também figurativiza a presença da umbanda, doutrina espiritualista originária do pensamento africano, pois esta partilha de valores éticos cristãos, que são refutados pelo enunciado instrucional. Entre os valores refutados, o enunciado visual figurativiza a adoração da cruz e reverência aos mortos, expressos no culto ritualístico dos antepassados. A umbanda apresenta explícita referência às crenças católicas: "Nos ritos da umbanda, as preces católicas e a invocação de Jesus, Maria e dos santos da igreja nas letras dos cantos sagrados continuam indispensáveis” (PRANDI, 2004, p. 228).

A presença do enunciado visual, ao concretizar e reforçar o repudiável, de acordo com a orientação argumentativa do discurso das TJ, instaura de maneira visível e palpável aos olhos do enunciatário, um culto tido como "errado" a esse sistema de valores.

Ao tomar como base as legendas que acompanham as fotografias da lição, observamos que a ancoragem se dá em nível polêmico. As relações estabelecidas, no que concerne à homologia entre o verbal e o visual, estabelecem no plano do conteúdo a figura central e emblemática do verdadeiro cristão, dada por meio das modalidades veridictórias. A imagem traçada para o enunciatário é a daquele que parece e é cristão. Assim, temos o verdadeiro (Testemunha de Jeová) e o falso (o outro) não nomeado.

O entrelaçamento das formulações, dado no plano de expressão (PE) por intermédio das letras com fonte de tamanho maior, sincretismo verbo-visual convergente e o entrelaçamento diagramático (associação das questões introdutórias com as explanações ao longo do texto, citações bíblicas como argumento de autoridade, respiro entre as colunas), remete ao tom professoral e viabilizador da leitura proposto no plano do conteúdo (PC). 
Podemos, depois da análise dos temas, das figuras e da homologação entre o visual e o verbal analisados no discurso da brochura, definir o éthos, o modo próprio de presença no mundo inerente à brochura de estudo bíblico. Tal análise constata a presença de um éthos mediador, de tom de voz professoral, que opera com a transmissão de saberes de crença. Entretanto, por causa do caráter de veridicção atribuído ao saber transmitido, por oposição aos saberes de crença de outros sistemas religiosos refutados no enunciado, verificamos também a presença de um éthos polêmico. Um éthos, de tom de voz alto, corporalidade altiva e caráter sério, que grita, polemiza e tece o "Outro" no próprio fio do discurso. 


\section{Capítulo IV. Dissensão religiosa: O espaço discursivo de divulgação religiosa na delimitação do estilo de totalidades antagônicas: A (Católica) e B (Testemunha de Jeová)}

"Não existe relação polêmica "em si”: a relação com o Outro é função da relação consigo mesmo". Dominique Maingueneau ${ }^{18}$

Isolamos, dentro do campo discursivo religioso, textos pertencentes ao espaço discursivo de divulgação religiosa, que julgamos pertinentes serem colocados em relação: o discurso Católico e o discurso das Testemunhas de Jeová (doravante TJ). Nosso fazer sancionador, ao recortar e delimitar totalidades, estabeleceu como corpus de referência (unus), gêneros como o catecismo e publicações de estudo bíblico voltadas tanto ao público adulto, quanto infanto-juvenil, das duas totalidades discursivas (totus) que supostamente se opõe entre si, "Catolicismo" e "TJ", para que se obtivesse o espaço discursivo.

Ao observar as recorrências dos mecanismos de construção do sentido dos textos, refletiremos sobre a noção de discurso de divulgação religiosa pertinente à cena enunciativa partilhada pelas totalidades em que se propõe um fazer-crer.

Dessa forma, buscamos nos ater a discursos instrucionais programadores, na medida em que possibilitam a aquisição de uma competência: saber e poder ser cristão.

PN de base: $\mathrm{S}_{1} \rightarrow \mathrm{PN}$ de uso [aceitar a doutrinação de um modo de vida cuja receita é dada no enunciado do texto de divulgação religiosa].

A abstração dada pela recorrência de um modo único de fazer e de ser, inerente ao espaço discursivo de divulgação religiosa, permitiu que procurássemos estabelecer uma

\footnotetext{
${ }^{18}$ MAINGUENEAU, Dominique. Gênese dos Discursos. Curitiba: Criar, 2005, p. 108.
} 
organização imanente, ao que corresponderia à configuração de uma homogeneidade regrada, ou seja, o estilo dos discursos inerentes à divulgação religiosa.

Para que tal proposta seja possível, a partir das análises dos enunciados de divulgação religiosa realizadas nos capítulos anteriores, acrescidas da metalinguagem teórica sobre o discurso religioso, procuramos estabelecer as peculiaridades que distinguem o discurso religioso fundador e o discurso de divulgação religiosa, os quais entendemos como cenas enunciativas complementares.

Existe o discurso religioso que se dá a ver como fundador e de divulgação religiosa. Tomamos, portanto, o campo do discurso religioso que se realiza por meio do espaço discursivo de divulgação religiosa e que alcança identidade própria por meio da fundação ou do discurso fundador.

Os textos instrucionais que materializam o espaço discursivo de divulgação religiosa constroem o éthos correspondente a duas cenografias diferenciadas, Catolicismo e TJ, a partir da escolha de uma mesma tipologia de discurso.

Cada texto de divulgação religiosa (unus), visto como materialização de um gênero (catecismo, publicação de estudo bíblico), permitirá que seja depreendido o éthos da totalidade recortada (totus), A (Igreja Católica) e B (TJ), na medida em que cada totalidade atende às próprias restrições de uma semântica global.

A análise do estilo, ainda segundo Discini (2004b, p. 36), “supõe recortar partes da totalidade. Em cada uma, está pressuposta a totalidade englobante e integral, já que se trata de um conjunto, ou bloco, de discursos". A totalidade (totus) será depreendida das partes (unus), uma vez que a unidade sempre pressupõe a totalidade.

Da relação entre totus e unus depreenderemos o estilo de cada totalidade com apoio do estabelecimento do fato de estilo, efeito de individualidade determinado pelo estabelecimento do percurso gerativo do sentido. 
A análise das unidades consideradas, ao permitir a depreensão de regularidades, confirmará o efeito de identidade, determinado pela relação entre o PC e o PE, ao que remeteremos a dois estilos diferenciados em referência ao modo de ser de cada uma das totalidades: A (Católica) e B (TJ).

Ao depreenderemos, portanto, por meio do percurso gerativo do sentido, o corpo do ator da enunciação que se identifica e se define pela totalidade de seus discursos, sustentaremos o efeito de sentido próprio a cada totalidade.

O fato de estilo será determinado tanto pelas recorrências do fechamento ideológico de um determinado discurso, quanto pelo efeito de diferença em relação ao "outro", ao responder de maneira polêmica às vozes que digladiam no interior do próprio texto, considerando o Catolicismo e a TJ segundo a divulgação religiosa de cada uma das instituições.

Desse modo, o fato de estilo também poderá ser visto como elemento diferencial, no que tange à relação entre o discurso do "eu" e do "outro", entendendo-se esse "outro" como a projeção do simulacro da totalidade antagônica instituída no interior do próprio texto.

Cada um dos sujeitos, pressupostos à totalidade discursiva de que fazem parte, enfeixa valorizações sociais e ideológicas com a determinação de diferentes modos de conduta a serem executados pelos participantes desse grupo social.

A recorrência das mesmas apreciações moralizantes, inerentes a cada totalidade e determinadas por meio da configuração interdiscursiva de um conjunto de temas e figuras ressemantizados de acordo com o sistema de restrições semânticas da totalidade, permite que se determine o valor do valor de uma totalidade.

O reconhecimento do fato de estilo, ao estabelecer deferentes modos de ser de cada totalidade, permitirá a depreensão de diferentes imagens-fim, isto é, diferentes éthos, com a concretização de um corpo, de um caráter e de um tom de voz na figura do ator da enunciação. 
Delinearemos, portanto, diferentes modos de ver, de sentir, de construir, e de representar o mundo em consonância com as restrições semânticas de cada totalidade. Remeteremos ao páthos diversificado, que corresponde aos diversos modos pelo qual o coenunciador (leitor pressuposto) se relaciona ao éthos do discurso de cada totalidade.

A determinação de diferentes imagens-fim, enquanto representações inerentes aos sujeitos de cada totalidade de discursos, confirmará diferentes construções do sentido, ao que remetemos, portanto, ao estilo de cada totalidade: estilo A (Totalidade A - Católico) e estilo B (Totalidade B - TJ).

\section{Discurso Religioso}

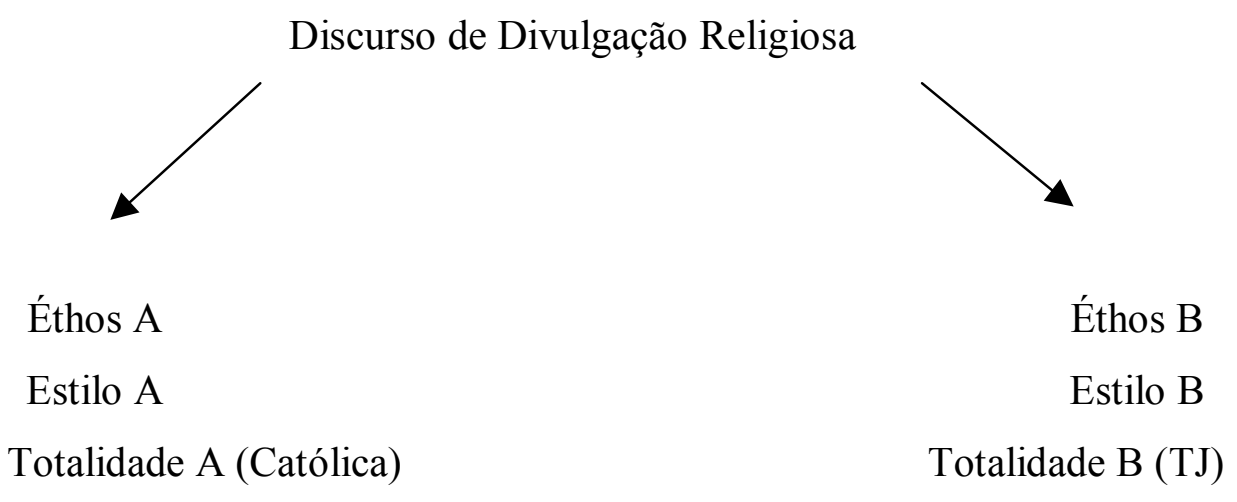

\section{Discurso Religioso Fundador e Discurso Religioso de Divulgação Religiosa}

Procuraremos nessa seção estabelecer as peculiaridades de construção do sentido do discurso religioso fundador e do discurso de divulgação religiosa. Lançaremos, portanto, um 
olhar diferenciador que busca estabelecer as singularidades e as diferenças entre os dois discursos considerados cenas enunciativas complementares.

\subsection{Discurso Religioso}

Inicialmente, procederemos à explicação do que consiste o campo de discurso religioso. Tomaremos como base as proposições de Fiorin (1988), entre outros. De acordo com Fiorin (1988, p. 39), a tarefa de definição do que constitui o discurso religioso não se coloca como problema para os crentes, dado que:

Para eles o discurso religioso é o que fala de Deus e de seus propósitos em relação aos homens. O analista, entretanto, deve explicar quais os mecanismos que engendram o efeito de sentido que se denomina "religioso" e a ordem de necessidades a que responde a produção desse efeito de sentido (FIORIN, 1988, p. 39).

A caracterização do que consiste o discurso religioso apresenta acentuada dificuldade, dada à variedade de gêneros que ele engloba. Podemos citar como pertencentes ao discurso religioso: o texto bíblico, com a grande variedade de discursos que o constitui (proféticos, evangélicos, apocalípticos, epistolares, etc.); o discurso teológico; o discurso militante; o sermão; o catecismo; o breviário; o discurso litúrgico da prece; o discurso sacramental; etc.

Dessa forma, apesar da variedade de gêneros apresentada, procuraremos demonstrar o que os constitui e os unifica como pertencentes à mesma esfera de sentido. Para tal, tomaremos como referência, unicamente, o discurso religioso cristão.

Apesar da diversidade do fenômeno religioso, é possível depreender uma unidade que singularize esse discurso em sua especificidade. 
O discurso constrói-se mediante o estabelecimento do simulacro da ilusão de um processo comunicacional reversível, em que os representantes de Deus na Terra (padres, pastores, anciãos), apesar de apenas reproduzir ou interpretar a palavra divina, parecem falar em nome de Deus. Desse modo, no plano do parecer, o agente religioso constitui-se como destinador, ao se instituir, na verdade, como destinatário, como mediador da voz divina com os enunciatários (fiéis). Temos, portanto, o simulacro da ilusão de reversibilidade instaurado.

Para os objetivos dessa tentativa de definir o discurso religioso, partimos inicialmente da definição de Orlandi (1996, p. 242-243), que o caracteriza como "aquele em que fala a voz de Deus: a voz do padre - ou do pregador, ou em geral, de qualquer representante seu - é a voz de Deus".

Ao tomar como base os níveis de manipulação do discurso religioso, observamos que a operacionalização dos simulacros que cada um dos atores envolvidos dirige um ao outro se dá em duas vertentes: do arquidestinador (Deus) para o destinador-mediador (agente religioso) tornado destinatário de Deus; e deste, o destinador mediador, para os destinatários (fiéis).

Desse modo, propomos dois programas narrativos de base na enunciação narrativizada dos gêneros pertencentes ao discurso religioso:

\section{PN1}

$\mathrm{S}_{1} \rightarrow \mathrm{S}_{2} \cap \mathrm{O}_{\mathrm{v}}$

$\mathrm{S}_{1}=$ arquidestinador (Deus, $\mathrm{O}$ Verbo)

$\mathrm{S}_{2}=$ destinador mediador (agente religioso)

$\mathrm{O}_{\mathrm{v}}=$ fé propagada 


\section{PN2}

$\mathrm{S}_{1} \rightarrow \mathrm{S}_{2} \cap \mathrm{O}_{\mathrm{v}}$

$\mathrm{S}_{1}=$ destinador mediador (agente religioso)

$\mathrm{S}_{2}=$ destinatário (fiel)

$\mathrm{O}_{\mathrm{v}}=$ graça divina

Dessa forma, devemos caracterizar a assimetria que constitui a relação entre o arquidestinador, o destinador mediador e o destinatário nesse discurso, dado que ambos pertencem a planos distintos: o arquidestinador (O Sujeito, Deus) pertence ao plano espiritual, o destinatário ao plano temporal (sujeito, fiéis) e o destinador mediador (agente religioso), se institui como mediador entre essas duas instâncias.

Dessa assimetria, forma característica da não-reversibilidade entre os planos espiritual e temporal que é própria a esse discurso, ocorrem distintos mecanismos de mediação estabelecidos, seja na ordem temporal por meio dos representantes da Igreja (Papa, Bispos, padres, pastores, anciãos, etc.), seja na ordem espiritual (Nossa Senhora, santos), ou ainda por meio da figura de Jesus Cristo, cuja natureza particular o faz ser o próprio Deus.

Podemos citar como marcas definitórias do discurso religioso: a assimetria entre os planos temporal e espacial. Quanto a essa assimetria, entendemo-la como a relação estabelecida entre o arquidestinador (Deus), o destinador mediador e o destinatário (fiéis), na medida em que ambos pertencem a ordens de mundo distintas e delimitadas hierarquicamente. $\mathrm{O}$ arquidestinador, ao pertencer ao plano espiritual, dominado pelo eixo da superatividade, está hierarquicamente superior ao destinador mediador e ao destinatário (fiéis), ambos pertencentes ao plano temporal, o qual é pautado pelo eixo da inferatividade. Vemos também o uso de antíteses, o uso do imperativo e do vocativo, a presença de metáforas, parábolas, paráfrases, sintagmas cristalizados, além de acentuada intertextualidade. 
De acordo com Bourdieu (1974), o discurso religioso tem como principais funções: i) o fornecimento de justificativas de existência ontológica (da vida do ser) e ii) o fornecimento de justificativas sociais de existência do ser, como ocupante de uma determinada posição na estrutura social.

Podemos conceber semioticamente o discurso religioso cristão, o qual estabeleceu o recorte textual deste corpus de análise, como um discurso caracterizado pelo resultado de um julgamento interpretativo dado por meio de um julgamento epistêmico. Tal julgamento epistêmico promove a adesão do sujeito ao enunciado de estado por meio do ato cognitivo do “crer”, sobredeterminado pela modalidade epistêmica da certeza (crer-dever-ser).

O poder religioso apresenta a sua especificidade na sistematização de uma "disposição duradoura", vista como visão de mundo a ser adotada pelos membros de um grupo institucional.

A concorrência pelo poder religioso deve sua especificidade (em relação, por exemplo, à concorrência que se estabelece no campo político) ao fato de que seu alvo reside no monopólio do exercício legítimo do poder de modificar em bases duradouras e em profundidade a prática e a visão de mundo dos leigos, impondo-lhes e inculcando-lhes um habitus religioso particular, isto é, uma disposição duradoura, generalizada e transferível de agir e de pensar conforme os princípios de uma visão (quase) sistemática do mundo e da existência (BOURDIEU, 1974, p. 88).

A noção de "disposição duradoura", estabelecida por Bourdieu (1974, p. 88), remete à categoria aspectual de duratividade, própria ao quadro teórico dos estudos lingüísticos e da semiótica.

A duratividade é um sema aspectual que indica, no eixo sintagmático, que um intervalo temporal, situado entre o termo incoativo e o termo terminativo, é inteiramente preenchido por um processo. Paradigmaticamente esse sema faz parte da categoria aspectual duratividade/puntualidade. Um mesmo intervalo temporal pode ser preenchido por grandezas, idênticas ou comparáveis, situadas no mesmo nível de derivação: dir-se-á, então, que se trata da duratividade descontínua 
(ou iteratividade), opondo-a, desse modo, à duratividade contínua, que caracteriza apenas um processo (GREIMAS; COURTÉS, 1989, p. 135).

Lembramos que Bourdieu (1974) se refere a outro quadro teórico: Sociologia. Trazemos o pensamento de Bourdieu (1974) para o quadro teórico da Semiótica, em que o texto é analisado na relação $\mathrm{PE} / \mathrm{PC}$, e em que se busca o efeito de sentido dado como mecanismo próprio de construção do sentido do discurso religioso, observados seus desdobramentos textuais e de gêneros.

Assim, de acordo com as definições de Bourdieu (1974), para que o enunciado religioso obtenha êxito, determinadas condições devem ser preenchidas.

\begin{abstract}
A natureza e a forma das interações diretas entre os agentes ou as instituições que estão empenhados nesta concorrência, e os instrumentos e as estratégias que utilizam nesta luta, dependem do sistema de interesses e da autoridade propriamente religiosa que cada um deles deve: a) à sua posição na divisão do trabalho de manipulação simbólica dos leigos e b) à sua posição na estrutura objetiva das relações de autoridade propriamente religiosa que definem o campo religioso (BOURDIEU, 1974, p. 88).
\end{abstract}

A eficácia simbólica compreende a relação que se estabelece entre "as propriedades do discurso, as propriedades daquele que o pronuncia e as propriedades da instituição que o autoriza a pronunciá-lo" (BOURDIEU, 1998, p. 89). Para a Semiótica essa noção se dá como simulacro.

Os simulacros são objetos imaginários, que não tem fundamento intersubjetivo, mas, mesmo assim, determinam as relações intersubjetivas. $\mathrm{O}$ sujeito de estado estabelece uma relação fiduciária - de confiança, de /crer/ com o simulacro que constrói. (BARROS, 2002, p. 64)

O discurso de autoridade sobrevalorizada apresenta sua especificidade no fato de que, para que ele exerça seu efeito, deve, além de ser compreendido, ser reconhecido como portador da Palavra Revelada. Esse reconhecimento dá-se mediante as modalidades epistêmicas, pelo fazer interpretativo do sujeito, ao emitir um juízo epistêmico sobre o 
enunciado de estado. Para que o reconhecimento de autoridade se dê: a) deve ser pronunciado por alguém autorizado a fazê-lo, hábil e apto a encarnar determinada classe de discursos; b) ser pronunciado em situação legítima, por enunciadores legítimos, diante de enunciatários legítimos; c) ser enunciado em formas sintáticas e semânticas legítimas. Essa noção remete ao conceito de lugar enunciativo e autoridade acumulada, próprios à Analise do Discurso de que a Semiótica incorporou seus conceitos.

Em geral, e isto desde seu início, a AD prefere formular as instâncias da enunciação em termos de "lugares", visando a enfatizar a preeminência e a preexistência da topografia social sobre os falantes que aí vêm se inscrever. Um conceito de lugar "cuja especificidade repousa sobre esse traço essencial segundo o qual cada um alcança a sua identidade a partir e no interior de um sistema de lugares que o ultrapassa". Esse primado do sistema de lugares é crucial a partir do momento em que raciocinamos em termos de formações discursivas; trata-se então, segundo o preceito de M. Foucault, de "determinar qual é a posição que se pode e deve ocupar cada indivíduo para ser dela sujeito". Isto equivale a dizer que a "teoria do discurso não é uma teoria do sujeito antes que este enuncie, mas uma teoria da instância da enunciação que é, ao mesmo tempo e intrinsecamente, um efeito de enunciado" (MAINGUENEAU, 1997, p. 32-33).

Assim sendo, para que se reconheça e se aceite a delegação da autoridade instituída por meio do discurso religioso, devem ser preenchidas condições litúrgicas, ritualísticas e institucionais. Em Semiótica, fala-se do fazer interpretativo, que remete às modalidades veridictórias e ao contrato fiduciário.

O contrato fiduciário põe em jogo o fazer persuasivo de parte do destinador e, em contrapartida, a adesão do destinatário: dessa maneira, se o objeto do fazer persuasivo é a veridicção (o dizer - verdadeiro) do enunciador, o contra-objeto, cuja obtenção é esperada, consiste em crer - verdadeiro que o enunciatário atribui ao estatuto do discurso-enunciado: nesse caso, o contrato fiduciário é um contrato enunciativo (ou contrato de veridicção) que garante o discurso-enunciado; se o contrato fiduciário sanciona um programa narrativo no interior do discurso, falar-se-á então de contrato enuncivo. A relação fiduciária é que se estabelece entre os dois planos, o do ser e o do parecer quando, graças ao fazer interpretativo, passa-se de um para outro, fazendo-se a asserção de um e de outro desses modos de existência (GREIMAS; COURTÉS, 1989, p. 184). 
No que diz respeito às condições litúrgicas, "prescrições que regem a forma da manifestação pública da autoridade" (cf. BOURDIEU, 1998, p. 91), devem ser preenchidas as condições referentes à etiqueta das cerimônias, ao código dos gestos e ao ordenamento oficial dos ritos. Como condição de reconhecimento e aceitação do discurso ritual, de tal forma que esse seja percebido e recebido como legítimo, os componentes do ritual religioso (agentes, instrumentos, momentos e lugares) devem estar adequados, de maneira que a abdicação de qualquer atributo simbólico (batina, lugares e objetos sagrados), processa a quebra do contrato de delegação de autoridade ao mediador: o padre, o pastor, o sujeito intermediário entre os fiéis e a Igreja.

Em Semiótica, a noção de símbolo entra em oposição às relações semi-simbólicas. As relações simbólicas devem ser entendidas como fundamento de uma representação baseada em uma convenção social, como a notação de uma relação, de uma constante entre dois elementos em uma determinada cultura. As relações semi-simbólicas, por oposição, possibilitam a depreensão de relações entre o plano do conteúdo e o plano de expressão dos textos em cada enunciado examinado, o que supõe cada e diferente situação de comunicação, tomando por princípio a isomorfia entre os dois planos da linguagem proposta por Hjelmslev (1975).

\subsection{Discurso religioso fundador}

A noção de discurso fundador pode ser entendida como um discurso que "funciona como referência básica no imaginário constitutivo” (cf. ORLANDI, 2003, p. 13). 
O que o caracteriza como fundador- em qualquer caso mas precipuamente nesse - é que ele cria uma nova tradição, ele re-significa o que veio antes e institui aí uma memória outra. É um momento de significação importante, diferenciado. [...] instituem um outro lugar de sentidos estabelecendo uma outra região para o repetível (a memória do dizer), aquela que a partir de então vai organizar outros e outros sentidos [...]. É a isso que chamamos discurso fundador (ORLANDI, 2003, p. 13).

Para a perspectiva da $\mathrm{AD}$, aqui também herdada pela Semiótica, temos a noção de "dêixis fundadora", passível de homologação ao discurso fundador. A dêixis fundadora "deve ser entendida como a(s) situação(ões) de enunciação anterior(es) que a dêixis atual utiliza para a repetição e da qual retira boa parte de sua legitimidade” (MAINGUENEAU, 1997, p. 42).

O discurso fundador pode ser considerado como um discurso primeiro sobre o qual outros textos falam. Esse discurso viabiliza a abertura de espaços discursivos, determinados por relações interdiscursivas contratuais ou polêmicas.

O texto bíblico, considerado como texto de referência primeiro, e, portanto, como discurso fundador dos discursos de divulgação religiosa, devido ao efeito de atemporalidade do discurso religioso, é a base para a discursivização dos discursos.

Acrescentaremos a noção de mito fundador ao relato bíblico, ao tomar as definições de Chaui (2006, p. 9). Dessa forma, ao adotar as concepções propostas pela autora, a noção de mito será concebida em três acepções: a) etimológica, como "narração pública de feitos lendários da comunidade"; b) antropológica, como "solução imaginária para tensões, conflitos e contradições que não encontram caminhos para serem resolvidos no nível da realidade"; c) psicanalítica, "como impulso à repetição de algo imaginário, que cria um bloqueio à percepção da realidade e impede lidar com ela" (CHAUI, 2006, p. 9). Evidentemente, consideramos o mito em sua função semiótica, o que significa descrever os textos do mito na relação $\mathrm{PC} / \mathrm{PE}$.

Um mito fundador é aquele que não cessa de encontrar novos meios para exprimir-se, novas linguagens, novos valores e idéias, de tal modo que, 
quanto mais parece ser outra coisa, tanto mais é a repetição de si mesmo (CHAUI, 2006, p. 9).

A Bíblia, advinda do termo grego ta bíblia 'os livros', constitui-se como a coleção de livros, considerados como escritos sob inspiração do Espírito Santo, em que judeus e cristãos reconhecem a palavra de Deus. A Bíblia é composta de 73 escritos e dividida em duas partes, denominadas de Antigo e Novo Testamento. O cânone das Escrituras na tradição católica constitui-se de 46 livros pertencentes ao Antigo Testamento e 27 ao Novo Testamento. Na versão protestante, a Bíblia apresenta 66 livros, divididos em 39 para o Antigo Testamento e 27 para o Novo.

O discurso bíblico conta com uma diversidade de gêneros, dos quais podemos destacar: a) fragmentos de epopéia; b) narrações históricas; c) listas genealógicas; d) narrações episódicas ou romanceadas; e) oráculos proféticos; f) sermões; g) textos legislativos; h) poemas; i) orações; j) ensaios filosóficos; k) cantos de amor; 1) cartas.

Vejamos como a autoridade das Sagradas Escrituras é constantemente invocada pelos discursos de divulgação religiosa das duas totalidades religiosas (Catolicismo e TJ):

a) Catolicismo:

21. Que importância tem o Antigo Testamento para os cristãos? Os cristãos veneram o Antigo Testamento como verdadeira Palavra de Deus: todos os seus escritos são divinamente inspirados e conservam um valor permanente. Eles dão testemunho da divina pedagogia do amor salvífico de Deus. Foram escritos sobretudo para preparar o advento de Cristo Salvador do universo.

22. Que importância tem o Novo Testamento para os cristãos?

O Novo Testamento, cujo objeto central é Jesus Cristo, confia-nos a verdade definitiva da Revelação divina. Nele, os quatro Evangelhos - de Mateus, Marcos, Lucas e João -, por serem o principal testemunho sobre a vida e a doutrina de Jesus, constituem o coração de todas as Escrituras e ocupam um lugar único na Igreja.

$[\ldots]$

24. Que função tem a Sagrada Escritura na vida da Igreja? 
A sagrada Escritura dá suporte e vigor á vida da Igreja. É para seus filhos firmeza da fé, alimento e fonte de vida espiritual. É a alma da teologia e da pregação pastoral. Diz o salmista: ela é "lâmpada para meus passos e luz no meu caminho" (S1 119, 105). A Igreja exorta por isso à freqüente leitura da Sagrada Escritura, porque "a ignorância das Escrituras é ignorância de Cristo” (São Jerônimo). (BENTO XVI, 2005, p. 25-26).

b) Testemunha de Jeová

\section{Lição 1}

\section{Como você pode saber o que Deus requer}

Que informações importantes contêm a Bíblia? (1)

Quem é o autor da Bíblia? (2)

Por que você deve estudar a Bíblia? (3)

1. A Bíblia é uma dádiva preciosa de Deus. É como a carta de um pai amoroso aos filhos. Conta-nos a verdade sobre Deus - quem ele é e o que representa. Explica como lidar com problemas e como conseguir verdadeira felicidade. Só a Bíblia nos diz o que temos de fazer para agradar a Deus. Salmo 1:1-3; Isaías 48:17, 18.

2. A Bíblia foi escrita por uns 40 homens, durante um período de 1.600 anos, a partir de 1513 AEC. É composta de 66 livros pequenos. Os escritores da Bíblia foram inspirados por Deus. Escreveram os pensamentos dele, não os seus próprios. De modo que Deus, no céu, não algum homem na Terra, é o Autor da Bíblia. - 2 Timóteo 3:16, 17; 2 Pedro 1:20, 21.

3. Deus certificou-se de que a Bíblia fosse copiada e preservada com exatidão. Mais Bíblias foram impressas do que qualquer outro livro. Nem todos se agradam de que você estude a Bíblia, mas não deixe que isso o impeça. Seu futuro eterno depende de você chegar a conhecer a Deus e de fazer a Sua vontade, apesar de qualquer tipo de oposição. - Mateus 5:1012; João 17:3 (O QUE DEUS requer de nós, 1996, p. 3).

As referências bíblicas permeiam os enunciados de divulgação religiosa. Trata-se da utilização do procedimento argumentativo da citação de autoridade, na qual a autoridade da Bíblia é constantemente invocada ao longo dos enunciados de divulgação, a fim de asseverar a veracidade do enunciado divulgador no desígnio divino como proveniente das Sagradas

\section{Escrituras.}

A autoridade da Bíblia é invocada por meio dos seguintes procedimentos de heterogeneidade mostrada e marcada, ao que corresponde, de acordo com as proposições de Authier-Revuz (cf. 1982), à presença do “outro" na cadeia do discurso, explicitamente 
delimitado por meio de marcas lingüísticas, como por exemplo: a) citação de autoridade; b) paráfrase (reduplicação mítica do discurso fundador); c) alusão.

Vejamos como esses procedimentos podem ser observados ao longo dos enunciados divulgadores:

a) citação de autoridade:

Discurso Católico:

298. Quando foi instituído esse sacramento?

O Senhor ressuscitado instituiu esse sacramento quando, na noite de Páscoa, apareceu a seus Apóstolos e lhes disse: "Recebei o Espírito Santo. A quem perdoardes os pecados serão perdoados; a quem os retiverdes, serão retidos" (Jo 20, 22-23) (BENTO XVI, 2005, p. 98) (grifo nosso).

Discurso da TJ:

1. Nem todas as crenças e costumes são maus. Mas Deus não os aprova quando se originam de religião falsa ou são contrários a outros ensinos bíblicos. - Mateus 15:6.

2. Trindade: É Jeová uma Trindade - três pessoas em um só Deus? Não! Jeová, o Pai, é "o único Deus verdadeiro". (João 17:3; Marcos 12:29) Jesus é Seu Filho primogênito e está sujeito a Deus. (1 Coríntios 11:3) O Pai é maior do que o Filho. (João 14:28) $O$ espírito santo não é pessoa; é a força ativa de Deus. - Gênesis 1:2; Atos 2:18 (...)(O QUE DEUS requer de nós, 1996, p. 22-23) (grifo nosso).

b) paráfrase (reduplicação mítica do discurso fundador):

Discurso da TJ:

\section{História 58}

Davi e Golias

OS FILISTEUS vieram novamente lutar contra Israel. Os três irmãos mais velhos de Davi estavam no exército de Saul. Certo dia, Jessé disse a Davi: 'Leve cereais e pão aos seus irmãos. Veja como estão passando.' 
Chegando ao acampamento do exército, Davi correu até à linha de batalha, para procurar seus irmãos. O gigante filisteu Golias apareceu para zombar dos israelitas. Fez isso cada manhã e cada tardinha, por 40 dias. Ele clamou: 'Escolham um homem para lutar comigo. Se vencer e me matar, seremos seus escravos. Mas, se eu vencer e o matar, vocês serão nossos escravos. Desafio-os a escolherem alguém para lutar comigo.'

Davi perguntou aos soldados: 'O que ganhará o homem que matar este filisteu e livrar Israel da vergonha?'

'Saul dará ao homem muitas riquezas', disse um soldado. 'E ele lhe dará sua filha em casamento.'

Mas, todos os israelitas estavam com medo de Golias, porque era muito grande. Tinha uns 3 metros de altura, e tinha outro soldado para carregar-lhe o escudo.

Alguns soldados foram contar ao Rei Saul que Davi queria lutar contra Golias. Mas, Saul disse a Davi: 'Não pode lutar contra este filisteu. Você é apenas rapaz, e ele foi toda a vida soldado.' Davi respondeu: 'Matei um urso e um leão que haviam levado ovelhas de meu pai. E este filisteu será como um deles. Jeová me ajudará.' Saul disse então: 'Vá, e Jeová esteja com você.'

Davi desceu a um riacho para apanhar cinco pedras lisas, que pôs na sua bolsa. Depois tomou a funda e foi ao encontro do gigante. Vendo-o Golias, quase não acreditou. Achou que era fácil matar Davi.

'Venha para cá', disse Golias, 'e eu vou dar seu cadáver às aves e aos animais'. Mas, Davi disse: 'Você vem a mim com espada, lança e dardo, mas eu o enfrento no nome de Jeová. Hoje, Jeová entregará você na minha mão e eu o abaterei.'

Então, Davi correu para Golias. Tirou uma pedra da bolsa, colocou-a na funda e atirou-a com toda a força. A pedra atingiu Golias bem na cabeça, e ele caiu morto! Vendo os filisteus que seu campeão havia caído, todos fugiram. Os israelitas correram atras deles e venceram a batalha.

1 Samuel 17:1-54(MEU LIVRO de Histórias Bíblicas, 1978, p. História 56).

c) alusão:

Discurso Católico:

\section{Como é prefigurado o Batismo na Antiga Aliança?}

$\mathrm{Na}$ Antiga Aliança encontram-se várias prefigurações do Batismo: a água fonte de vida e de morte; $\underline{a}$ arca de Noé, que salva por meio da água; $\underline{a}$ passagem do Mar vermelho, que liberta Israel da escravidão egípcia; $\underline{a}$ travessia do Rio Jordão, que introduz Israel na terra prometida, imagem da vida eterna (BENTO XVI, 2005, p. 89) (grifo nosso).

De acordo com Chaui (2006, p. 70), o tempo bíblico, de modo diferente ao tempo cósmico (natural) e épico (histórico), “é dramático, pois a história sagrada é não somente 
sagrada, mas também o drama do afastamento do homem de Deus e da promessa de reconciliação de Deus com o homem". O termo "testamento" que caracteriza a composição bíblica substitui o antigo termo grego que significava pacto ou aliança. O relato bíblico é a aliança feita por Deus com os homens por intermédio de Moisés (Antigo Testamento) e, posteriormente, pelo ministério de Jesus Cristo (Novo Testamento).

De fato, a cristologia nasce em dois movimentos sucessivos: o primeiro movimento, o Antigo Testamento é interpretado como profecia do advento do Messias; no movimento seguinte (quando, historicamente, o mundo não acabou depois da Ressurreição de Cristo e o Juízo Final tarda a acontecer enquanto o mal se espalha por toda a parte), o Novo Testamento passou a ser interpretado como profecia do Segundo Advento, a Segunda Vinda do Messias no fim dos tempos, com o qual, finalmente, a história estará completamente consumada (CHAUI, 2006, p. 72).

Dessa forma, o tempo bíblico não exprime a circularidade dos ciclos da natureza, nem tampouco a narração de feitos humanos, mas configura-se como um tempo sagrado, caracterizado como o drama do reencontro do homem com Deus. Portanto, podemos conceber a história cristã como uma operação de Deus no tempo. Falamos de um tempo semantizado de modo próprio.

Desse modo, podemos afirmar que há no relato bíblico "um discurso nãotemporalizado e não-espacializado, que se temporaliza e se espacializa no comentário" (FIORIN, 1988, p. 142).

Para esclarecer, lembramos que a não-temporalização e a não espacialização dizem respeito a efeitos de sentido dados no texto e pelo texto. Tomemos como exemplo a utilização do presente atemporal ou omnitemporal, observado nas análises dos enunciados de divulgação. 


\section{3. Discurso religioso de divulgação religiosa}

A magia performativa do ritual funciona completamente apenas na medida em que o procurador religioso, incumbido de realizá-lo em nome do grupo, age como uma espécie de médium entre o grupo e ele próprio. É o grupo que, por seu intermédio, exerce sobre ele mesmo a eficácia mágica contida no enunciado performativo (BOURDIEU, 1998, p. 95).

A “magia performativa", a que Bourdieu (1998) se refere, faz-nos pensar numa troca de papéis actanciais: destinador e destinatário do programa narrativo de base da enunciação dos textos de divulgação religiosa. Nesse caso, em princípio, temos três possibilidades, que retomam programas narrativos de base na enunciação narrativizada do discurso religioso fundador, na medida em que os enunciadores da Bíblia já almejam o fazer-crer.

\section{$\mathrm{S}_{1} \rightarrow \mathrm{S}_{2} \cap$ Ov graça divina}

a) $\mathrm{S}_{1}$ (Deus/ Profeta); $\mathrm{S}_{2}$ (agente religioso);

b) $\mathrm{S}_{1}$ (agente religioso); $\mathrm{S}_{2}$ (fiel);

c) $\mathrm{S}_{1}$ (fiel); $\mathrm{S}_{2}$ (agente religioso).

Na tentativa de estabelecer as peculiaridades dos discursos de divulgação religiosa, tomamos como ponto de partida os desenvolvimentos efetuados por Panier (1986) e Delorme e Geoltrain (cf. 1982). Esses conceitos foram retomados por Fiorin (cf. 1988) ao estabelecer a definição do discurso religioso teológico e militante, mediante o confronto que buscou estabelecer entre o discurso político e o religioso. Utilizamos-nos também dos pressupostos de Maingueneau (cf. 2005a) ao discorrer sobre as categorias de discurso devoto do jansenismo e do humanismo devoto. Incorporamos os conceitos propostos, procurando 
ampliá-los por meio do estabelecimento da noção de discurso de divulgação religiosa. A expansão desse conceito fez-se possível mediante o estabelecimento da análise semiótica dos textos pertencentes ao espaço discursivo de divulgação religiosa das duas totalidades religiosas, que delimitamos estabelecer em confronto. A análise nos permitiu, mediante o estabelecimento do estilo de cada unidade (unus), concernente à divulgação das duas instituições religiosas, depreender o fato de estilo inerente ao espaço discursivo de divulgação religiosa. Estabelecemos, portanto, a homogeneidade regrada, o estilo, o tom de voz, caráter e corporalidade, característicos dessa tipologia de discurso divulgador.

Estabelecemos como recorte textual prioritário, textos que materializam gêneros de divulgação religiosa (catecismos e publicações de estudo bíblico) de duas totalidades, Catolicismo e TJ, consideradas para análise. Desse modo, sem levar em conta os gêneros discursivos dos textos considerados para os propósitos dessa dissertação, poderíamos definílos segundo Fiorin (1988), ao retomar Delorme e Geoltrain (1982), sob a denominação de "discurso religioso teológico ou militante", ou simplesmente "discurso comentário", conceito que ampliamos com a utilização do termo discurso de divulgação religiosa.

Os discursos de divulgação religiosa caracterizam-se pela sua constituição como um fazer interpretativo sobre um discurso primeiro, ao qual, de acordo com Orlandi (2003), entendemos como discurso fundador.

Delorme e Geoltrain (1982, p. 113), ao se referirem à tese de Panier (1986), projetam a seguinte definição:

Assim, texto e comentário se apresentam como variantes ou usos diferentes de um mesmo sistema. O novo contexto oferece aos elementos do texto de referência o estabelecimento de dois tipos de recategorização. De um lado, enunciados narrativos deslocam-se ao longo do esquema narrativo [...]. De outro lado, as figuras do texto comentado podem se encontrar em configurações discursivas mais vastas, no seio das quais o comentário seleciona outros percursos e outros valores (DELORME; GEOLTRAIN, 1982, p. 113). 
Assim sendo, dadas as interpretações suscitadas pela Bíblia, vista como discurso fundador do discurso de divulgação religiosa, podemos, de acordo com as afirmações de Panier (1986), caracterizar o discurso de divulgação religiosa sob a noção do discursocomentário, na medida em que este, ao caracterizar-se como um texto de interpretação do relato bíblico, pode ser definido como um discurso segundo "produzido a partir de um primeiro discurso, e que se apresenta como equivalente do ponto de vista do sentido" (PANIER, 1986, p. 267).

O comentário é um discurso em que se indica e se realiza a passagem de uma narrativa (discurso figurativo) ao discurso não-figurativo que toma essa narrativa como objeto, e em que se manifestam os procedimentos que se encontram igualmente em funcionamento nos discursos com pretensão científica (PANIER, 1986, p. 268).

Pensando semioticamente, acusamos uma configuração (inter)discursiva comum entre o discurso fundador e o discurso de divulgação religiosa.

A noção de configuração discursiva, representa uma convergência semântica entre os textos, dada por meio de um núcleo invariante de figuras, sob as quais circulam diferentes variações temático-figurativas.

Entretanto, para que possamos entender semioticamente a noção de "discurso comentário" de que nos utilizamos, acrescentamos o conceito de "discurso devoto", determinado por Maingueneau (2005a, p. 29) ao estabelecer a oposição entre o espaço discursivo do jansenismo e do humanismo devoto. Segundo o autor, "os discursos devotos" apresentam uma característica doutrinária própria, “se entendemos por isso enunciados cuja finalidade é menos especulativa do que prática: ensinar aos fiéis quais são os comportamentos que eles devem adotar para viver cristãmente em uma sociedade determinada" (MAINGUENEAU, 2005a, p. 29). 
Os discursos de divulgação religiosa operacionalizam duas categorias de perfórmance: o fazer comunicativo ou persuasivo, no qual o comentário opera com a transmissão de um saber que se pretende como a verdade (fazer-saber); e um fazer interpretativo, no qual o “comentário interpreta a narrativa que toma por objeto" (cf. PANIER, 1986, p. 268). O fazer interpretativo exercido pela narrativa de comentário deve ser considerado como efeito de sentido produzido por esse discurso.

Dessa forma, ao tomar como base, de acordo com as afirmações de Panier (1986), os dois problemas de que se compõem a análise do comentário, correspondentes às duas características de performance propostas, podemos, considerar os diferentes papéis actanciais assumidos pelo destinador (comentador) e pelo destinatário (fiel).

Desse modo, o discurso de divulgação religiosa constitui-se por meio de um procedimento parafrástico de função essencialmente citativa que, pautado pela construção de simulacros, apresenta na enunciação dos diversos gêneros de divulgação religiosa uma função de reescritura e interpretação do relato bíblico. Esse discurso, servindo como mediador entre um destinador divino superior e aqueles destinatários a quem se busca atingir, por meio de um texto instrucional e propagador da doutrina das Sagradas Escrituras, apóia-se em uma manipulação enunciativa para que o leitor (actante coletivo), tendo sido persuadido e aderido ao objeto modal "saber", ou melhor, "dever-saber" e, portanto, deonticamente modalizado, queira aprender os fundamentos bíblicos em conformidade com a ideologia que o fundamenta.

Vejamos a seguir as características dos discursos de divulgação religiosa obtidas por meio das análises realizadas nos capítulos anteriores (II e III) e que nos permitem estabelecer a hipótese discursiva a respeito dos enunciados de divulgação religiosa.

A oposição semântica fundamental é estabelecida nesse discurso entre os termos contrários (sagrado e profano / divino e humano) e subcontrários (não-sagrado e não-profano/ não-divino e não-humano). O sistema de valores é determinado pela seguinte axiologia: os 
termos sagrado e não-profano são axiologizados com valores eufóricos e os termos profano e não-sagrado com valores disfóricos.

Para o espaço discursivo de divulgação religiosa, podemos estabelecer um programa narrativo de base, dado na enunciação pressuposta ao discurso:

\begin{tabular}{|cccc|}
$\mathrm{S}_{1} \rightarrow$ & $\mathrm{S}_{2}$ & $\cap \mathrm{O}_{\mathrm{v}}$ "graça divina" \\
$\downarrow$ & $\downarrow$ & $\downarrow$ \\
agente & fiel & poder, \\
religioso & \multicolumn{2}{c}{ dever }
\end{tabular}

O discurso religioso de divulgação, ao operacionalizar a dimensão cognitiva, apresenta ao homem um programa de ação por meio da execução de um fazer persuasivo, ou seja, por meio da proposição de um dever-fazer ao destinatário. Temos assim, um sistema de modalidades deônticas com a instalação de prescrições (dever-fazer) e interdições (dever não fazer).

Vejamos como Greimas e Courtés (s.d, p. 107) estabelecem a definição do sistema modal deôntico:

Do ponto de vista semiótico, a estrutura modal deôntica aparece quando o enunciado modal, tendo por predicado o dever, sobredetermina e rege o enunciado do fazer. A projeção binarizante dessa estrutura no quadrado semiótico permite a formulação da categoria modal deôntica:

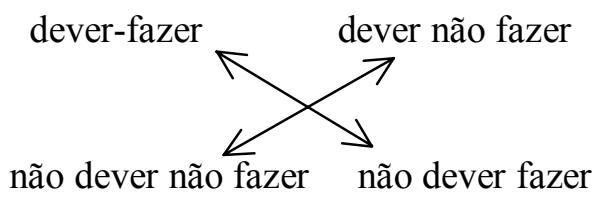

Dada a assimetria instituída entre enunciador e enunciatário, poder e saber são dispostos assimetricamente entre eles. Caracterizado por meio de uma operação fiduciária sobredeterminada pelo crer, o enunciador destina-se a persuadir o enunciatário por meio de 
manipulações da ordem do poder, nas quais são propostas ao mesmo tempo manipulações e intimidações.

Nesse discurso, o efeito de sentido de paroxismo autoritário chega ao limite, de tal modo que não se admitem questionamentos. O representante de Deus, ao se apropriar da palavra divina, o faz sem autonomia alguma. A voz de Deus se coloca como a voz do enunciador primeiro, onipotente e onisciente, cujo enunciado, ao lembrar os atributos divinos, configura-se por meio da modalidade epistêmica da certeza (crer-ser), devido à ausência de quaisquer elementos modais que possam levantar incerteza (não crer ser).

As modalidades epistêmicas dizem respeito à competência do enunciatário (ou, no caso do discurso narrativo, do Destinador final) que, em seguida a seu fazer interpretativo, "toma a cargo", assume (ou sanciona) as posições cognitivas formuladas pelo enunciador (ou submetidas pelo Sujeito). Na medida em que no interior do contrato enunciativo (implícito ou explícito) o enunciador exerce um fazer persuasivo (isto é, um fazer-crer), o enunciatário por sua vez, finaliza o seu fazer interpretativo por um juízo epistêmico (isto é, por um crer) que ele emite sobre os enunciados de estado que lhe são submetidos (GREIMAS; COURTÉS, s.d, p. 151).

O sujeito, ao aceitar ser deonticamente modalizado por esse discurso, apresenta um julgamento ético sobre os enunciados deônticos. Esse julgamento se refere às estruturas modais éticas que sobredeterminam os enunciados deônticos. "Compreende-se que haveria duas estruturas modais éticas, uma em que o /crer/ sobredetermina um /dever-fazer/ e outra em que ele sobredetermina um /poder fazer/" (GREIMAS; COURTÉS, 1986, p. 143).

Assim, após o julgamento ético efetuado, o sujeito adquire um crer dever fazer (engajamento) e um crer poder fazer (competência).

Consideremos o PN de base da enunciação pressuposta à divulgação religiosa com os actantes: destinador, destinatário e objeto de valor. Esses actantes serão, no discurso, preenchidos por temas e figuras, tal como pede uma enunciação comprometida com a formação discursiva A (Catolicismo) ou B (TJ). Repetimos: 


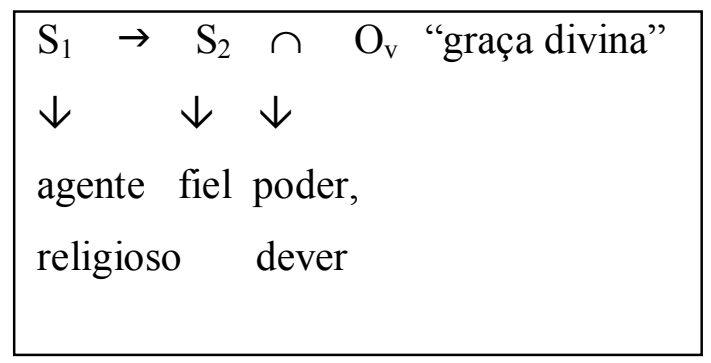

Teremos, então, na enunciação pressuposta ao espaço discursivo de divulgação religiosa, um destinador (S1), que busca levar o enunciatário (S2) a querer e dever entrar em conjunção com o valor do valor proposto por cada totalidade: A (Católica) e B (TJ).

Nos discursos de divulgação religiosa, vimos que os textos priorizam ora os sistemas enunciativos (representantes diretos do agora da enunciação, o que, por sua vez, gera efeito de subjetividade), ora os sistemas enuncivos, que se ancoram num marco referencial pretérito e deslocam o narrado em relação ao tempo do então. É própria da divulgação religiosa essa dicotomização dos sistemas temporais, para que novas totalidades possam emergir e fundamentar dois estilos antagônicos e diferenciados.

Ao depreender a estrutura composicional dos gêneros de divulgação religiosa, verificamos como se biparte cada estilo (TJ ou Católico) segundo a seleção de um sistema espacial tomado como dominante em textos de divulgação religiosa.

Definimos, portanto, uma espacialização característica dos discursos de divulgação religiosa, e que, organizada ao redor da instância do aqui, constrói o simulacro da cena de doação de saber. A irreversibilidade de posições enunciativas é definidora dessa tipologia de discursos. O enunciado divulgador constrói, por meio da ilusão de reversibilidade, uma proxêmica da ordem da estabilidade com a definição hierárquica de lugares enunciativos do arquidestinador (Deus), do mestre (destinador mediador e, portanto, divulgador da Palavra Divina absoluta) e do discípulo (destinatário e receptor do saber religioso). Teremos, portanto, uma espacialização determinada pela direção superativa no eixo da verticalidade, a fim de que 
o destinatário (fiel) estabeleça o "alto" como categoria para que assim seja possível retomar o seu encontro com Deus.

Vemos emergir, portanto, nos discursos de divulgação religiosa, um tom de "orientação" determinado por uma voz que define o estabelecimento de dois lugares enunciativos: o mestre (aquele que sabe e deve transmitir o conhecimento) e o discípulo (aquele que deve aprender).

Dessa forma, podemos concluir que os textos que materializam a divulgação religiosa alcançam certa especificidade rítmica para que se defina a cena enunciativa. Os discursos do espaço discursivo de divulgação religiosa pertencem a uma esfera de circulação do sentido, a que se pressupõe o "fazer-saber", ou seja, a dimensão da doação de um objeto de valor cognitivo, que é o "saber das coisas de Deus", dado como objeto desejável e possível, e tem como preocupação de encadear injunções, ensinamentos, direta ou indiretamente. Dessa forma, os textos do espaço discursivo considerado se agrupam segundo elementos extensos, para fundar uma práxis semiótica da divulgação da fé religiosa. Para isso, o andamento tende, assim como o estilo, em princípio, a apresentar marcas de desaceleração.

A lentidão, própria aos discursos de divulgação religiosa de caráter instrucional, corresponde à preocupação com a previsibilidade apresentada por esses discursos. O caráter de ensinamento, próprio aos discursos de divulgação, pode ser associado, portanto, à lentidão e desaceleração características.

Contrariamente ao discurso fundador, pautado por um do sujeito determinado segundo a concentração, há no discurso de divulgação religiosa, um sujeito determinado segundo a expansão. Essa expansão se verifica pela explicitação do enredamento do preenchimento de lacunas semânticas, com o estabelecimento de fronteiras traçadas para o fiel. O fiel tem de ser orientado e ensinado: é necessário que se privilegie o contínuo, para que a previsibilidade 
sustente com segurança o fiel. Por meio dessa lentidão é que se espera encontrar a imagem do sujeito determinada nos textos que materializam a divulgação religiosa.

Dessa maneira, a descrição dos mecanismos de construção do sentido nos enunciados enfeixados pelo discurso religioso e pelo discurso de divulgação, e que entendemos como cenas enunciativas complementares, nos permite compreender a instituição de um pacto fiduciário diferenciado no que corresponde à socialização do conhecimento e se refere a esses dois discursos. O preenchimento semântico dos lugares enunciativos do enunciador e do enunciatário apresenta variações no papel temático e figurativo de cada um desses sujeitos na passagem da cena enunciativa do discurso religioso para a cena enunciativa do discurso de divulgação religiosa. Podemos, concluir, portanto, que discurso religioso de divulgação, de maneira distinta ao discurso religioso fundador, institui a veridicção e a fidúcia segundo o proselitismo.

\section{O páthos dado como confronto de paixões}

Este item se propõe estudar a maneira pela qual as instituições religiosas cotejadas, apesar de materializar em seus textos instrucionais o discurso de divulgação religiosa, apresentam duas cenografias distintas, que remetem a duas totalidades, a partir da escolha de gêneros de divulgação voltados ao enunciatário infanto-juvenil.

$\mathrm{O}$ ator da enunciação da totalidade discursiva católica, apresentado segundo o sacramento da Crisma, que textualizado ou implícito nos percursos figurativos e temáticos, confirma o sujeito que apresenta um modo próprio de presença social. O tom de voz beligerante que traz como argumento de autoridade "Jesus nos faz seus soldados" prende-se a 
uma organização diagramática dada segundo o equilíbrio das frases e das imagens, o minimalismo cromático e o mundo da racionalidade dominante. Assim, proliferam figuras próprias às seqüências injuntivas como: "Missão a cumprir" e "Devo seguir para a vida".

Do universo deôntico depreende-se o éthos que se apóia nos dois pilares modais: dever-ser fiel; não dever-ser contraditório e cético. Emparelham-se a estas as modalidades que sustentam a prescrição (dever-fazer) e a interdição (dever não fazer).

Buscando o ideal de perfeição, em nenhum momento o espírito de luta por Deus e pela Igreja arrefece no Primeiro Catecismo da Doutrina Cristã. Ser habitado pelo Espírito Santo é ser semantizado com o poder e saber lutar por Deus e pela Igreja. A figura da crisma, emblemática da doação do Espírito Santo, adquire o estatuto de doadora do poder e do saber ser soldado de Jesus.

Interessantemente a crisma, que é detalhada como elemento que fornece maior resistência aos assaltos da tentação, não oferece um detalhamento figurativo da sua composição. Mantém-se o inexplicável, para manter-se a fé.

A totalidade discursiva pressuposta ao Primeiro Catecismo da Doutrina Cristã manipula o leitor por meio da recorrência de textos de tipo injuntivo, que dão lições explícitas ou ensinamentos claros de como preparar o cristão para a Crisma.

Veremos do espaço discursivo de divulgação religiosa emergir dois ethé. O primeiro trabalha predominantemente com abstrações, tomando até termos concretos em seu valor genérico. É o caso do sacramento da Crisma ensinado aos cristãos. Esse é o éthos Católico, que não se destina a contar episódios bíblicos, nem reduplicar atores do enunciado do texto de fundação. Um éthos que prioriza explicações dos mistérios da fé mantendo, entretanto, a intocabilidade dos mesmos mistérios. O que é concretamente a crisma? O leitor do catecismo católico não saberá, nem deverá querer saber. 
O discurso de divulgação católica traz a seguinte configuração discursiva: o católico deve lutar como um soldado para obter a graça eterna.

Já o segundo éthos, o da TJ, contrariamente ao éthos católico, apresenta um tom de voz mais dócil ao se constituir por meio da docilidade ficcional da história de "Davi e Golias”. Observamos que o texto instrucional de divulgação religiosa da totalidade discursiva das TJ apresenta-se como um texto narrativo, que diferentemente do enunciado do catecismo considerado, ao apresentar a prescrição a ser realizada de modo explícito por meio da utilização de lições, este a estabelece no modo do segredo, ao operar com a utilização de narrativas exemplares.

As estratégias do enunciador constituem-se na ocultação do eu-aqui-agora, ancorando os movimentos do sentido nos atores do enunciado "Davi e Golias" num tempo enuncivo figurativizado como o tempo de então e num espaço topicalizado como o espaço do alhures, com a emergência dos atores do enunciado.

Esse é o éthos da TJ, que, ao operar com a reduplicação mítica do discurso fundante, faz a divulgação religiosa por meio da concretude das figuras, firmando o mito pelo mito. Um éthos mítico, altivo, superior, autoritário e detentor de uma verdade inquestionável, pois é inspirado e respaldado nas verdades enunciadas no discurso fundante das Sagradas Escrituras.

Ao tomarmos como base que a discursivização da paixão tem como característica essencial a projeção e operacionalização dos simulacros que cada um dos interlocutores envolvidos dirige um ao outro, observamos que essa operacionalização se dá em duas vertentes: do arquidestinador (Deus) para o destinador (agente religioso) e desse para os destinatários (fiéis), no que diz respeito a cada uma das totalidades cotejadas.

Desse modo, observamos que o simulacro instituído com relação ao arquidestinador na totalidade católica caracteriza-se como da ordem de uma maior deontologia, pautando-se por uma sanção mais intensa. O enunciador da TJ, por oposição, constrói-se por meio do 
simulacro de uma menor deontologia, pautando-se por uma sanção menos intensa. Assim, vemos emergir, diferentes imagens de enunciatário com base em cada uma das cenas enunciativas cotejadas. O simulacro instituído pelo enunciado do catecismo constitui-se como um enunciado prescritivo, dado por meio de um éthos construído na ordem da inteligibilidade e da racionalidade dominantes. Pautado pela doxologia do dever-ser e saber-ser, visa estabelecer um contrato fiduciário com o enunciatário para que este adquira a competência esperada e possa manter-se, por meio da paixão do medo, em conjunção com os valores propugnados pelo catolicismo.

Já o simulacro instituído pela cena enunciativa das Testemunhas de Jeová, pressupõe por oposição, por meio da paixão da esperança, um leitor mais crente na utopia do sonho a ser realizado na supra-realidade ficcional de base mitológica. A reconstrução da utopia do sonho, ao reavivar o mito para o enunciatário infanto-juvenil, tem por objetivo disseminar o conteúdo das Sagradas Escrituras, sem a preocupação com a exposição e disseminação de dogmas.

Assim, podemos observar que, apesar das unidades consideradas materializarem o mesmo gênero divulgação religiosa, apresentam distintas cenografias, constituídas não mais pelo gênero, mais pelos próprios discursos, em resposta aos anseios de um determinado grupo social.

\section{3. Éthos e antiéthos na divulgação da fé}

Este item tem por objetivo estabelecer a polêmica ressurgida entre as duas totalidades discursivas (Católica e TJ), voltadas ao enunciatário adulto, na medida em que cada uma delas 
tematiza e figurativiza o mundo de maneira contraditória, para construir cada qual, o mundo segundo representações homogeneizadas ou cindidas e, portanto, heterogêneas.

Observamos, por meio das análises realizadas ao longo do terceiro capítulo dessa dissertação, a contrariedade dos modos de presença no mundo que emergem de cada uma das totalidades.

A noção de heterogeneidade é constitutiva dos discursos. Tomaremos a noção do "primado do interdiscurso" estabelecida por Maingueneau (1997, 2005a), inscrita na perspectiva bakthiniana em referência ao caráter essencialmente dialógico de todo enunciado.

Ao reconhecer o primado do interdiscurso, compreenderemos o espaço discursivo como uma rede de interações semânticas que circunscreve a especificidade de um discurso, ao estabelecer as relações desse discurso com seu "Outro".

Desse modo, ao termos procedido ao recorte de duas totalidades antagônicas, teremos, portanto, o embate entre duas interincompreensões, o que resulta em duas profissões de fé que se opõe entre si.

A assimilação de simulacros das imagens ditadas pela crença se refere aos diferentes modos de pensar o mundo, relacionados aos interesses de grupos sociais postos em confronto e ligados à instituição religiosa que os legitima.

A formação ideológica dos discursos de divulgação religiosa é constituída por um éthos mediador, de tom de voz próprio daquele que ensina, orienta e dita ao leitor aprendiz (páthos) determinadas regras de conduta de como pensar e proceder por meio de formações discursivas. As formações discursivas agrupam ao longo dos textos de divulgação religiosa temas que refletem diferentes categorizações de mundo, que se materializam através de figuras, em consonância com as restrições de cada totalidade discursiva.

Tendo recortado duas totalidades a partir da divulgação religiosa teremos a possibilidade de ressemantização de um tema como a inevitabilidade da morte. A 
inevitabilidade da morte, no que diz respeito à temática da reverência aos mortos: (Finados), terá os semas retomados e alterados ao passar de uma totalidade para outra. Dessa forma, embora presente em ambos os discursos, esse tema será ressemantizado pela negação no discurso das TJ.

\section{O que exprimem os funerais?}

Os funerais, embora celebrados segundo diferentes ritos correspondentes às situações e às tradições de cada região, exprimem o caráter pascal da morte cristã na esperança da ressurreição, e o sentido da comunhão com o defunto particularmente mediante a oração e a purificação da sua alma. 1684-1685 (BENTO XVI, 2005, p. 110-111)

5. Medo dos mortos: Os mortos não podem fazer nem sentir nada. Não podemos ajudá-los, nem podem eles prejudicar-nos. (Salmo 146:4; Eclesiastes 9:5, 10) A alma morre; não continua viva após a morte. (Ezequiel 18:4) Mas às vezes anjos iníquos, chamados demônios, fingem ser espíritos de mortos. Os costumes que têm que ver com o medo ou a adoração dos mortos são errados. - Isaías 8:19 (O QUE DEUS requer de nós, 1996, p. 23)

Tomemos agora o tema da Comunhão com Cristo e a sua Igreja (Eucaristia), ponto central na celebração litúrgica "Sacramental” da Igreja Católica.

Transcrevemos a seguir, excertos do Compêndio do Catecismo da Igreja Católica e do compêndio Raciocínio à base das Escrituras (TJ):

a) Compêndio do Catecismo da Igreja Católica:

\section{O SACRAMENTO DA EUCARISTIA}

\section{O que é a Eucaristia?}

É o próprio sacrifício do Corpo e do Sangue do Senhor Jesus, que ele instituiu para perpetuar pelos séculos, até seu retorno, o sacrifício da cruz, confiando assim à sua Igreja o memorial de sua Morte e Ressurreição. É o sinal da unidade, o vínculo da caridade, o banquete pascal, no qual se recebe Cristo, a alma é coberta de graça e é dado o penhor da vida eterna. 132213231409

[...]

274. O que representa a Eucaristia na vida da Igreja?

É fonte e ápice de toda a vida cristã. Na Eucaristia, atingem o seu clímax a ação santificante de Deus para conosco e o nosso culto para com ele. Ela encerra todo o bem espiritual da Igreja: o mesmo Cristo, nossa Páscoa. A 
comunhão da vida divina e a unidade do Povo de Deus são expressas e realizadas pela Eucaristia. Mediante a celebração eucarística, já nos unimos à liturgia do Céu e antecipamos a vida eterna. 1324-1327 1407 (BENTO XVI, 2005, p. 93-94).

b) Raciocínio à base das Escrituras (TJ):

Missa

Definição: Segundo a Sagrada Congregação de Ritos da Igreja Católica Romana, a Missa é "-Um sacrifício em que se perpetua o Sacrifício da Cruz; - Um memorial da morte e ressurreição do Senhor, que disse 'fazei isto em minha memória' (Lucas 22:19); - Um banquete sagrado em que, por meio da comunhão do Corpo e do Sangue do Senhor, o Povo de Deus participa dos benefícios do Sacrifício Pascal, renova a Nova Aliança que Deus fez com o homem uma vez para sempre por meio do Sangue de Cristo, e com fé e esperança prenuncia e antevê o banquete escatológico no reino do Pai, proclamando a morte do Senhor 'até a Sua vinda'." (Eucharisticum Mysterium, de 25 de maio de 1967) É o modo de a Igreja Católica fazer o que entende que Jesus Cristo fez na Última Ceia.

\section{Transformam-se realmente o pão e o vinho no corpo e no sangue de} Cristo?

Numa "Solene Profissão de Fé", em 30 de junho de 1968, o Papa Paulo VI declarou: "Cremos que, assim como o pão e o vinho consagrados pelo Senhor na Última Ceia se transformaram no Seu Corpo e no Seu Sangue, que haviam de ser oferecidos por nós na cruz, o pão e o vinho consagrados pelo sacerdote são transformados no Corpo e no Sangue de Cristo entronizado gloriosamente no céu, e Nós cremos que a misteriosa presença do Senhor, sob a aparência desses elementos, que aos nossos sentidos, parecem depois da Consagração iguais àquilo que eram antes, é uma presença verdadeira, real e substancial. . . . Esta transformação misteriosa é mui apropriadamente chamada pela Igreja de transubstanciação." (Official Catholic Teachings - Christ Our Lord, Wilmington, N.C., EUA; 1978, de Amanda G. Watlington, p. 411.) Concordam as Escrituras Sagradas com essa crença? [...]

\section{Que queria Jesus dizer com o que falou em João 6:53-57?}

"Jesus lhes respondeu . ... 'Em verdade, em verdade, vos digo: se não comerdes a carne do Filho do Homem e não beberdes o seu sangue, não tereis a vida em vós. Quem come a minha carne e bebe o meu sangue tem a vida eterna e eu o ressuscitarei no último dia. Pois a minha carne é verdadeira comida e o meu sangue, verdadeira bebida. Quem come a minha carne e bebe o meu sangue permanece em mim e eu nele. Assim como o Pai, que vive, me enviou e eu vivo pelo Pai, também aquele que comer de mim viverá por mim." - João 6:53-57, $B J$.

Deve-se entender que isto significa que eles deviam literalmente comer a carne e beber o sangue de Jesus? Se assim fosse, Jesus estaria incentivando 
a violar a Lei que Deus havia dado a Israel por intermédio de Moisés. Essa Lei proibia o consumo de qualquer tipo de sangue. (Lev. 17:10-12) Ao invés de advogar tal coisa, Jesus falou fortemente contra violar quaisquer dos requisitos da Lei. (Mat. 5:17-19) Portanto, o que Jesus tinha em mente só podia ser comer e beber em sentido figurativo, por se exercer fé no valor do seu perfeito sacrifício humano. - Veja João $3: 16 ; 4: 14 ; 6: 35,40$ (RACIOCÍNIOS à base das Escrituras, 1989, p. 238-240). (grifo nosso)

O discurso da TJ, ao polemizar o discurso do catolicismo, responde aos temas e figuras que lhe parecem mais ameaçadores, escolhendo alguns pontos de ataque.

Nos excertos recortados, observamos que o discurso da TJ toma um tema central ao catolicismo: a celebração da Comunhão com Cristo e a sua Igreja (Eucaristia), e por meio do procedimento de ilustração, constrói uma argumentação atravessando seu outro (catolicismo) pela exclusão.

A condição do outro, identificado em fragmentos localizados desse excerto, aparece como uma espécie de "engodo necessário". Tomemos a utilização das aspas que tendem a cercear o discurso católico. A utilização da heterogeneidade mostrada e marcada, com a utilização das aspas, isenta o enunciador da responsabilidade pelo que está escrito. Fora das aspas tudo se remete à homogeneidade e inquestionalidade de um discurso tido como o portador da palavra "verdadeira". Tudo o que estiver dentro das aspas é postulado como errôneo.

Numa "Solene Profissão de Fé", em 30 de junho de 1968, o Papa Paulo VI declarou: "Cremos que, assim como o pão e o vinho consagrados pelo Senhor na Última Ceia se transformaram no Seu Corpo e no Seu Sangue, que haviam de ser oferecidos por nós na cruz, o pão e o vinho consagrados pelo sacerdote são transformados no Corpo e no Sangue de Cristo entronizado gloriosamente no céu, e Nós cremos que a misteriosa presença do Senhor, sob a aparência desses elementos, que aos nossos sentidos, parecem depois da Consagração iguais àquilo que eram antes, é uma presença verdadeira, real e substancial. . . . Esta transformação misteriosa é mui apropriadamente chamada pela Igreja de transubstanciação." (Official Catholic Teachings - Christ Our Lord, Wilmington, N.C., EUA; 1978, de Amanda G. Watlington, p. 411.) Concordam as Escrituras Sagradas com essa crença? (RACIOCÍNIOS à base das Escrituras, 1989, p. 239). (grifo nosso) 
O catolicismo é inserido nesse discurso como simulacro a ser rechaçado, negado de ponta a ponta. O outro (catolicismo) é, portanto, traduzido no registro negativo do próprio sistema das TJ.

Em seguida, o enunciador, ao invocar em seu intermédio da autoridade das Sagradas Escrituras, tende a anular o discurso antagonista. $\mathrm{O}$ enunciador da totalidade discursiva das TJ, ao polemizar, tende a desqualificar seu adversário, com a demonstração de que esse violaria as regras que incidem sobre o código dogmático.

Deve-se entender que isto significa que eles deviam literalmente comer a carne e beber o sangue de Jesus? $\underline{\text { Se assim fosse, Jesus estaria incentivando a }}$ violar a Lei que Deus havia dado a Israel por intermédio de Moisés. Essa Lei proibia o consumo de qualquer tipo de sangue (Lev. 17:10-12) (RACIOCÍNIOS à base das Escrituras, 1989, p. 240). (grifo nosso)

A própria filtragem das citações de autoridade bíblica, que tendem a mostrar a veracidade do discurso das TJ, por oposição ao catolicismo, só é depreensível no próprio círculo do mesmo, pois essa filtragem é coerente com o próprio sistema de formação semânticas do qual partilha.

Tomemos como base exemplos de temas e figuras extraídos do enunciado verbal da brochura de estudo bíblico, analisados no terceiro capítulo dessa dissertação e que remetem à construções contraditórias de mundo, de modo a se configurar em uma totalidade (TJ) a negação de seu contrário (Catolicismo). O enunciador das TJ pauta seu discurso pela negação dos seguintes temas pertencentes ao discurso católico no enunciado instrucional considerado: a) necessidade de celebração da solenidade da santíssima trindade: a trindade de Deus; b) necessidade de celebração do natal e da páscoa; c) necessidade de celebração de aniversários natalícios; d) reverência aos mortos: (Finados); e) a reverência à cruz com seu poder simbólico: exaltação da santa cruz. 
A observação dos procedimentos de tematização e figurativização, inerentes à brochura de estudo bíblico, permitiu tecer algumas observações concernentes à “interincompreensão constitutiva", para a qual podemos postular a interseção entre os dois discursos: Católico e TJ. A incorporação dos percursos temáticos e figurativos do discurso católico desenvolve-se mediante a utilização do procedimento interdiscursivo de citação em nível polêmico.

Esse processo de duplas traduções permite-nos aprofundar o mecanismo polêmico. Cada uma das formações discursivas do espaço discursivo só pode traduzir como "negativas", inaceitáveis, as unidades de sentido construídas por seu Outro, pois é através desta rejeição que cada uma define a sua identidade. Uma formação discursiva opõe dois conjuntos de categorias semânticas, as reivindicadas (chamemo-las de "positivas") e as recusadas (as "negativas"). Note-se que ela projeta as unidades "positivas" deste Outro sobre as categorias de seu próprio sistema; para preservar sua identidade, o discurso só pode relacionar-se com o Outro do espaço discursivo através do simulacro que dele constrói. Chamaremos de discurso agente aquele que se encontra em posição de "tradutor", de construtor de simulacro, e de discurso paciente aquele que desta forma é traduzido (MAINGUENEAU, 1997, p. 122).

Ao considerar o sistema de restrições semânticas que organiza cada uma das totalidades consideradas, verificamos a presença do tom polêmico, da negação do universo semântico do outro, da pejoração do outro como simulacro na medida em que essa “interincompreensão" repousa sob dois conjuntos de semas: os positivos reivindicados e os negativos rejeitados. Desse modo, o "Outro" (o Catolicismo) é traduzido nas categorias do registro negativo dentro do sistema das TJ. O modo próprio de polemizar dá-se pela colocação do outro em erro. O "Outro" (catolicismo), ao apresentar como positivos os semas rejeitados pela totalidade discursiva das TJ, é desqualificado enquanto adversário.

O éthos da TJ. constrói a intersubjetividade dada polemicamente por meio do embate entre duas inter(in)compreensões de mundo, que supõe duas compreensões da fé em Deus e que consolida a inter(in)compreensão constitutiva de cada discurso. 
$\mathrm{O}$ embate entre duas interincompreensões nos permite postular a existência de um éthos e de um antiéthos inerente à divulgação da fé. Descrever o éthos das totalidades discursivas postas em confronto permite recuperar o caráter, o tom de voz, o corpo e o estilo de sujeitos determinados pelo modo de dizer e viabilizados pela identificação de temas e figuras ressemantizados pelos próprios discursos.

A esse éthos, que ressurge a polêmica em seu próprio discurso, se opõe o éthos católico pautado pelo efeito de monofonia.

O catolicismo confirma o antiéthos da TJ, que ao silenciar a polêmica, confirma um acento único de voz, um efeito de monofonia. Embora ambas as totalidades configurem-se como discursos autoritários, de verdade única e de voz altiva, o discurso católico, ao abafar as vozes em conflito, confirma-se como um discurso monofônico, de voz "marmórea", inquestionável e respaldada pelos valores da tradição católica.

O éthos da TJ, de modo contrário, só se constitui por oposição ao outro (catolicismo), pelo embate de duas posições determinadas pelo ressurgimento da polêmica.

Desse modo, delineamos, em consonância a cada totalidade A (Católica) e B (TJ), um éthos que operacionaliza a depreensão de dois estilos, de duas profissões de fé, que são determinadas por meio dos diferentes modos de discursivização de temas e figuras. 


\section{CONCLUSÃO}

"Quanto a ti, Daniel, guarda em segredo estas palavras e mantém lacrado o livro até o tempo do Fim".

Daniel 12,4

Este trabalho é resultado da curiosidade que o fenômeno religioso nos desperta e da escassez considerável de estudos a esse respeito no Brasil. Dentre os autores de cujas obras nos utilizamos, citamos: Bourdieu (1974); Delorme e Geoltrain (1982); Discini (2005a); Fiorin (1988); Maingueneau (2005a); Orlandi (1996); Panier (1986). Podemos notar que a abordagem do fenômeno religioso, ora restringe-se ao âmbito sociológico, ora apresenta um desenvolvimento incipiente dentro da teoria semiótica e da $\mathrm{AD}$ francesa. E, sobretudo, no que diz respeito ao corpus delimitado segundo os propósitos desta dissertação, um corpus doutrinário voltado ao ensino e instrução religiosa, tal escassez torna-se ainda mais contundente.

Estabelecemos como objeto de estudo, dentro do campo discursivo religioso, textos pertencentes ao espaço discursivo de divulgação religiosa de duas totalidades, A (Católica) e B (TJ), supostamente confrontantes e voltadas tanto ao enunciatário adulto, quanto ao infantojuvenil.

O estabelecimento de uma pesquisa dessa natureza, pautada pelo cotejo de textos de divulgação religiosa de duas instituições religiosas antagônicas, mediante a utilização do aparato da semiótica greimasiana, acrescida dos princípios da $\mathrm{AD}$ francesa, fazia-se necessário no quadro atual de pesquisas, como foi afirmado. Queríamos entender o confronto entre diferentes construções de sentido via discursos opostos, confrontados no ato da análise.

As análises dos enunciados foram realizadas com a utilização do arcabouço teórico da teoria semiótica e da $\mathrm{AD}$ francesa, o que significa a consideração de um referente interno ao discurso. Por isso, o ator da enunciação, ou éthos, foi depreendido dos próprios enunciados. 
Consideramos, então, os textos em sua materialidade, tendo por princípio que a apreensão do sentido não é algo exterior e apriorístico ao signo, mas resultante da reunião dos dois planos compreendidos na linguagem, o plano da expressão e o plano do conteúdo.

Para a elaboração desta pesquisa, procedeu-se inicialmente a consideração de um percurso gerativo do sentido, seguido de breves considerações a respeito da materialização da categoria plástica dos referidos textos, para que, mediante a análise de recorrências, pudéssemos estabelecer uma organização imanente a ambas as totalidades dos textos, ou seja, o estilo dos discursos inerentes à divulgação religiosa.

Consideramos também o sujeito da percepção, que ao imprimir um ritmo aos seus discursos, contribuiu para a delimitação do éthos.

A partir das análises dos enunciados e ao observar as recorrências dos mecanismos de construção do sentido dos enunciados reunidos pelo discurso religioso fundador e pelo discurso de divulgação religiosa, procuramos estabelecer as particularidades que distinguem o discurso religioso fundador e o discurso de divulgação religiosa.

O preenchimento semântico dos lugares enunciativos do enunciador e do enunciatário apresenta variações no papel temático e figurativo de cada um desses sujeitos na passagem da cena enunciativa do discurso religioso para a cena enunciativa do discurso de divulgação religiosa.

Esperamos poder ter cumprido os objetivos de descrever mecanismos de construção do sentido nos enunciados enfeixados pelo discurso religioso e pelo discurso de divulgação religiosa, os quais entendemos como cenas enunciativas complementares, já que para o primeiro discurso fica pressuposto um pacto fiduciário diferenciado daquele estabelecido pelo segundo discurso na socialização do conhecimento. 
Esta dissertação procurou, portanto, entender por que a cena enunciativa do discurso fundador apresenta peculiaridades que a distinguem do discurso de divulgação religiosa. Aqui e não lá se institui a veridicção e a fidúcia segundo o proselitismo.

Desse modo, passamos a designar a noção de discurso de divulgação religiosa, ao conceito pertinente à cena enunciativa proposta pelos gêneros doutrinários (catecismo, livro instrucional, brochura de estudo bíblico). O espaço discursivo de divulgação religiosa foi descrito por apresentar uma cena enunciativa que propõe fazer-crer, e mais do que isso, uma cena que propõe fazer-saber, ou seja, doutrinar conforme determinado modo de vida, tido como o apregoado pelos valores de uma determinada formação ideológica. Os enunciados que materializam os discursos concernentes a cada totalidade, para que se tenha o espaço discursivo, puderam ser descritos como textos instrucionais injuntivos, na medida em que possibilitam a aquisição de uma competência para que os sujeitos se tornem sujeitos cristãos, como enunciatários de ambas as totalidades: A (Católica) e B (TJ).

O que a análise também pôde observar, justamente devido às recorrências e categorias estabelecidas, foi o fato de que, mediante os mecanismos de construção do sentido das unidades consideradas, os textos instrucionais que materializam o espaço discursivo de divulgação religiosa constroem o éthos correspondente a duas cenografias diferentes: a da TJ e a da Igreja Católica, dois ethé; a partir da escolha da mesma tipologia de discurso. Por isso remetemos a duas totalidades, dois ethé, a partir do exame da escolha enunciativa feita pelo ator da enunciação de cada totalidade. Deve-se ressaltar que a análise dos enunciados cotejados tornou possível descrever o espaço discursivo como totalidades em confronto,voltada cada qual tanto ao público adulto quanto ao infanto-juvenil.

Ao estabelecermos, portanto, por meio do percurso gerativo do sentido, o corpo do ator da enunciação que se identifica e se define em cada unidade (unus) recortada, 
sustentamos o efeito de sentido próprio à cada totalidade, ao que remetemos a dois estilos diferenciados.

Determinamos, portanto, o fato de estilo inerente a cada uma das totalidades, tanto pelas recorrências do fechamento ideológico de cada uma delas, quanto por meio do efeito de diferença em relação ao "outro", ao responder às vozes do "outro" instauradas no próprio texto, de maneira polêmica, considerado o Catolicismo e a Testemunha de Jeová, segundo a divulgação religiosa de cada uma das instituições.

A depreensão do éthos correspondente a cada totalidade discursiva examinada só se tornou possível mediante o exame da concretização de uma interincompreensão constitutiva: um processo de tradução generalizada entre distintas profissões de fé que se opõe entre si. Observamos, portanto, o embate entre duas construções de mundo, o que nos permitiu postular a existência de um éthos e de um antiéthos inerente à divulgação da fé. Descrever o éthos das totalidades discursivas postas em confronto permitiu recuperar o caráter, o tom de voz, o corpo e o estilo de sujeitos determinados pelo modo de dizer e viabilizados pela identificação de temas e figuras ressemantizados de uma totalidade para outra.

A formação ideológica pertinente aos discursos instrucionais de divulgação religiosa, ao se constituir por um éthos de tom de voz mediador, característico daquele que ensina e orienta ao leitor-aprendiz determinadas regras de conduta de como proceder, propiciou também que fossem delimitados diferentes leitores em conformidade aos interesses de cada formação discursiva.

Podemos citar, com relação ao corpus infanto-juvenil, a cenografia professoral construída para a totalidade A (Católica), ao operar um texto estruturado em perguntas e respostas, contrariamente à totalidade $\mathrm{B}(\mathrm{TJ})$, com o éthos professoral construído na esfera do segredo e que opera com narrativas exemplares. Dessa forma, vimos emergirem diferentes imagens de enunciatário em cada uma das cenas enunciativas cotejadas. $\mathrm{O}$ simulacro 
instituído pela totalidade A (Catolicismo), com a utilização da doxologia do dever-ser e saberser, determinados pelo caráter coercitivo impresso ao enunciado catequético, pressupôs um sujeito pautado pelo dever estar em conjunção com os valores propostos mediante a paixão do medo. A totalidade B (TJ), por oposição, ao caracterizar a paixão da esperança, pressupôs o simulacro de um leitor crente na utopia do sonho a ser realizado na supra-realidade ficcional de base mitológica. A reconstrução da utopia do sonho, reavivando o mito para o enunciatário infanto-juvenil, teve por objetivo disseminar prioritariamente o conteúdo das Sagradas Escrituras de uma maneira adequada a seu enunciatário pressuposto, sem se preocupar com a exposição e disseminação de dogmas.

Vimos, também, serem confirmadas diferentes totalidades, A e B, de acordo com os interesses e expectativas do éthos pressuposto que se materializou e tomou corpo mediante a depreensão dos mecanismos de construção do sentido dos próprios textos.

A totalidade A (Católica), nos textos de divulgação para o leitor adulto, construiu um caráter mais monofônico do que o observado em relação à totalidade discursiva $\mathrm{B}(\mathrm{TJ})$. A totalidade A, ao silenciar a polêmica, confirma o acento único de voz altiva, "marmórea" e inquestionável de um éthos respaldado pelos valores da tradição católica. A esse modo de presença se opôs a totalidade $\mathrm{B}$, que ao fazer ressurgir a polêmica, edifica um éthos beligerante que tem por objetivo digladiar e apanhar o outro (catolicismo) em erro. Vimos erigir diante de nosso olhar de analista o embate de duas compreensões antagônicas em relação ao universo religioso. O diálogo de ataque unilateral constituiu o éthos da TJ, ao reavivar e reconstruir o antiéthos católico dentro de seu próprio sistema de restrições semânticas como um engodo, um simulacro a ser rechaçado.

Esperamos, dessa forma, ter cumprido nosso objetivo inicial. Pudemos descrever mecanismos segundo os quais, a partir do recorte analítico proposto, foi depreendida a fé 
contemplada por meio de duas diferentes instituições religiosas. Assim tornou-se possível a delimitação de dois ethé, como duas construções do Céu e da Terra.

Concluímos esse trabalho, desejosos de que possamos ter contribuído para a ampliação do entendimento da cena fundadora, a Bíblia Sagrada, do próprio discurso religioso e do espaço discursivo de divulgação religiosa.

Entretanto, a análise deixa aberta a possibilidade de ampliar a relação estabelecida entre discursos no espaço discursivo de divulgação religiosa. A tal fato podemos acrescentar, além do Catolicismo e da TJ, outros discursos de distintos grupos religiosos construídos no país, quer sejam evangélicos, pentecostais, neopentencostais, adventistas ou neocristãos. Discursos antagônicos postos em confronto geram o espaço discursivo. Logo, esta dissertação pode ter continuidade de pesquisa. Faz-se necessária também a ampliação da pesquisa a respeito da utilização dos gêneros textuais correspondentes à divulgação religiosa, no que diz respeito a publicações que não se restrinjam unicamente ao caráter doutrinário, de ensino e instrução religiosa. Portanto, a pesquisa em relação à utilização de diversos gêneros de divulgação religiosa (revistas, periódicos, semanários litúrgico-catequéticos, liturgias diárias, livros de estudo bíblico, brochuras, catecismos, tratados, panfletos, folhetos de estudo bíblico, livros de orações, etc.), das duas instituições religiosas contempladas, e quem sabe até, acrescidas de outros discursos, poderia delinear, de forma mais abrangente, a tipologia dos discursos de divulgação religiosa que buscamos propor neste estudo.

Mediante estas considerações, esperamos poder ter contribuído de alguma forma com o estudo dos discursos de divulgação religiosa, com o exame da própria esfera de circulação do sentido religioso, ou seja, com reflexões a respeito do discurso religioso, como enunciado, enunciação, éthos e estilo. 


\section{REFERÊNCIAS BIBLIOGRÁFICAS}

ABBAGANANO, Nicola. Dicionário de Filosofia. São Paulo: Martins Fontes, 2000.

ALTHUSSER, Louis. Ideologia e Aparelhos Ideológicos do Estado. $3^{\mathrm{a}}$.ed. São Paulo: Editorial Presença, 1980.

ALVES, Rubem. O que é Religião. 6a . ed. São Paulo: Loyola, 2005.

AMORIM, Marília. O pesquisador e seu outro: Bakhtin nas ciências Humanas. São Paulo: Musa, 2004.

AMOSSY, Ruth. (org.) Imagens de si no discurso: a construção do éthos. São Paulo: Contexto, 2005.

AUTHIER-REVUZ.J. "Hetérogénéité montée et hétérogénéité constitutive: élements pour une aprouche de l'autre dans le discours." In: DRLAV: Paris: Centre de Recherches de 1’Université de Paris, Revue de Linguistique, VIIi, 26, 1982. p. 91- 151.

.Heterogeneidades enunciativas. In: Cadernos Lingüísticos 19. Campinas: UNICAMP, 1990.p. 24- 42.

BAKHTIN, Mikhail. Problemas da Poética de Dostoiévski. 2a .ed. Rio de Janeiro: Forense Universitária, 1997.

- A Cultura Popular na Idade Média e no Renascimento: o contexto de François Rabelais. 4a. ed. São Paulo: HUCITEC, 1999.

. Estética da criação verbal. 4a . ed. São Paulo, Martins Fontes, 2003.

. Marxismo e Filosofia da Linguagem. São Paulo: Hucitec, 2004.

BARROS, Diana Luz Pessoa de. Procedimientos del plano de la expresión y construcción de los sentidos. In Semiótica de lo visual. Tópicos del Seminário, Puebla, n. 13, n.1, p. 137$157,2005$.

Teoria Semiótica do Texto. São Paulo: Ática, 2005. 
. Teoria do Discurso: Fundamentos Semióticos. 3ª ed. São Paulo: Humanitas, 2002.

. "Estudos do discurso". In: Fiorin, José Luiz (org) Introdução à Lingüística. II. Princípios de análise. São Paulo: Contexto, 2003a.

Interação em anúncios publicitários. In: PRETI, Dino (org.). Interação na fala e na escrita. São Paulo: Humanitas/FFLCH/USP, 2003 b.

BARROS, Diana Luz Pessoa de e FIORIN, José Luiz (org). Dialogismo, polifonia, intertextualidade. São Paulo: EDUSP, 2003.

BARTHES, Roland. A retórica da imagem. In: O óbvio e o obtuso. Lisboa: Edições 70, 1984.

BENTO XVI. Compêndio do Catecismo da Igreja Católica. São Paulo: Loyola, 2005.

BENVENISTE, Émile. Da subjetividade na linguagem. In: Problemas de Lingüística Geral I. $4^{\text {a }}$. ed. Campinas, SP: Pontes, 1995. p. 284-293.

BERTRAND, Denis. Caminhos da Semiótica Literária. Bauru, SP: EDUSC, 2003.

BÍBLIA de Jerusalém. São Paulo: Paulus, 2004.

BORTOLINI, Pe. José. A missa explicada parte por parte. São Paulo: Paulus, 2006.

BOURDIEU, Pierre. La distinction critique sociale du jugement. Paris: Minuit, 1979.

. A economia das trocas simbólicas. São Paulo: Perspectiva, 1974.

A linguagem autorizada: as condições sociais da eficácia do discurso ritual. In: $A$ economia das trocas lingüísticas: o que falar quer dizer. São Paulo: EDUSP, 1998.

BRANDÃO, Junito de Souza. Dicionário mítico-etimológico da mitologia grega. 2a. Ed. Petrópolis: Vozes, 1993. 
BR $\phi$ NDAL, Viggo. Omnis et Totus. Actes Sémiotiques - Documents VIII, 72. Paris : Groupe de Recherches sémio-linguistiques ; École de Hautes Études en Sciences Sociales, 1986. p. 11-18.

BRUNEL, P. Dicionário de Mitos Literários. Rio de Janeiro: José Olympio, 1997.

CALLAYE, Félicien. As grandes religiões. 6a. ed. São Paulo: IBRASA, 1998.

CAMPBELL, J. O poder do mito. São Paulo: Paulo: Palas Atena, 2005.

CARDEAL ARNS, Paulo Evaristo. O que é igreja. 3a . ed. São Paulo: Brasiliense, 1981.

CARVALHO, Paulo César de. Fragmentos epistolares de um discurso amoroso: elementos para uma análise semiótica do estatuto do gênero Carta de Amor. Dissertação de Mestrado. São Paulo: Universidade de São Paulo, 2005.

CASSIRER, ERNEST. Antropologia Filosófica: Ensaio sobre o Homem. São Paulo: Editora Mestre JOU, 1972.

CAVALCANTE, Marianne Carvalho Bezerra. Mapeamento e produção de sentido: os links no hipertexto. In: MARCUSCHI, Luiz Antônio \& XAVIER, Antônio Carlos (orgs) Hipertexto e Gêneros Digitais. 2a . ed. Rio de Janeiro: Lucerna, 2005. p. 163-169.

CHAUÍ, Marilena. Os trabalhos da memória. In: BOSI, Ecléa. Memória e Sociedade: lembranças de velhos. São Paulo: T.A. Queiroz, 1983.

.O que é ideologia. São Paulo: Brasiliense, 2004.

. Brasil: Mito fundador e sociedade autoritária. São Paulo: Editora Fundação Perseu Abramo, 2006.

CHARAUDEAU, Patrick. Discurso das Mídias. São Paulo: Contexto, 2006.

Charaudeau, P.; MAINGUENEAU, D. Dicionário de Análise do Discurso. São Paulo: Contexto, 2004.

CITELLI, Adilson. Linguagem e persuasão. 6a.ed. São Paulo: Ática, 1991. 
CORTINA, Arnaldo. Relação entre o verbal e o visual: leitura de uma gravura de Dürer, feita por Saramago. Significação, São Paulo, n. 19, p.182-197, 2003.

DABEZIES, A. Mitos primitivos e mitos literários. In: BRUNEL, P. Dicionário de Mitos Literários. Rio de Janeiro: José Olympio, 1997. p. 731-735.

DEGRANDIS, Robert; SCHUBERT, Linda. A cura pela missa. São Paulo: Loyola, 2004.

DELORME, J. Analyse sémiotique du discour et étude de la bible. In : Semiotiotique e Bible. Lyon : Revue trimestrielle publiée sous la direction du Centre pour l' Analyse du Discours Religieux (CADIR), no. 66, junho de 1992.p.37-44.

DELORME, J.; GEOLTRAIN, P. Le discours religieux. In : COQUET, J.C. Semiotique : l'école de Paris. Paris : Hachette, 1982.p.103-126.

DISCINI, Norma. Intertextualidade e conto maravilhoso. $2^{\mathrm{a}}$. ed. São Paulo: Humanitas, 2004a.

. O estilo nos textos. São Paulo: Contexto, 2004b.

. A Comunicação nos textos. São Paulo: Contexto, 2005a.

. HQ e poema: diálogo entre textos. In: LOPES, Ivã Carlos e HERNANDES, Nilton (orgs.). In: Semiótica: objetos e práticas. São Paulo: Contexto, 2005b.

.Identidade e Modo de Presença. In: II Congresso Internacional- Brasil, Identidade e alteridade. Anais. N.2. vol.1. São Paulo: Associação Brasileira de Estudos Semióticos, 2005c. 1 CD-ROM .

. Carnavalização. In: BRAIT, Beth (org). Bakhtin: outros conceitos - chave. São Paulo: Contexto, 2006a. p. 53-93.

. Provérbios, gênero e estilo. In: Neusa Barbosa Santos (Org.). Língua Portuguesa: reflexões lusófonas. 1a. ed. São Paulo: EDUC, 2006b, v.01, p. 157-167.

Análise: Liras, de Tomás A Gonzaga. Cópia xerografada. 
DUBOIS, J. et alii. Dicionário de Lingüística. São Paulo: Cultrix, 1996.

DURKHEIM, Émile. As formas elementares da vida religiosa. São Paulo: Martins Fontes, 2003.

ELIADE, M. Tratado de História das Religiões. São Paulo: Martins Fontes, 1993.

Mito e realidade. São Paulo: Perspectiva, 2004.

EM QUE CRÊEM as Testemunhas de Jeová? São Paulo: Sociedade Torre de Vigia de Bíblias e Tratados, 1987.

FIORIN, José Luiz. O regime de 1964: Discurso e Ideologia. São Paulo: Atual, 1988.

A lógica da neutralidade: um caso de aspectualização do ator. Estudos Lingüísticos. XVIII Anais de seminários do GEL. Lorena: Prefeitura Municipal de Lorena, 1989. p. 348355.

. Algumas considerações sobre o medo e a vergonha. Cruzeiro Semiótico 11-12: Porto, Portugal ,1992. p. 55-63. Ática, 2002.

As astúcias da enunciação: as categorias de pessoa, espaço e tempo. São Paulo:

.Linguagem e ideologia. São Paulo: Ática, 2003a.

Polifonia Textual e Discursiva. In: BARROS, Diana Luz Pessoa de \& FIORIN, José Luiz (orgs). Dialogismo, Polifonia, Intertextualidade. São Paulo: EDUSP, 2003 b.

.Teoria dos Signos. In: Fiorin, José Luiz (org) Introdução à Lingüistica. I.Objetos teóricos. São Paulo: Contexto, 2003c.

.Elementos de Análise do Discurso. São Paulo: Contexto, 2005a.

.Gêneros e tipos textuais. In: Hugo Mari; Ivete Walty; Zélia Versiani. (Org.). Ensaios sobre leitura. 1 ed. Belo Horizonte: Editora da PUCMinas, 2005b, v. 1, p. 101-117. 
Introdução ao pensamento de Bakhtin. São Paulo: Ática, 2006.

.A noção de texto na semiótica. Cópia xerografada.

.O Páthos do enunciatário. Cópia xerografada.

.Para uma definição das linguagens sincréticas. Cópia xerografada.

$\overline{\mathrm{FLOCH}}$, Jean-Marie. Petites Mythologies de l'oeil et de l'esprit: pour une Sémiotique Plastique. Paris: Editions Hadès-Benjamins, 1985.

. Semiótica plástica e linguagem publicitária. Significação. Araraquara, 6, 1987.p. 29-

50.

. Alguns conceitos Fundamentais em Semiótica Geral. São Paulo, CPS/PUC-SP:

Documentos de Estudo do CPS, vol. 1, 2001.

FONTANILLE, J.; ZILBERBERG, C. Tensão e significação. São Paulo: Humanitas, 2001.

FRAISE, Paul. Psycologie du rytme. Paris: PUF, 1974.

GREIMAS, A.J. Du Sens II. Essais sémiótiques. Paris: Seuil, 1983.

GREIMAS; COURTÉS, J. Sémiotique: dictonnaire raisonné de la théorie du langage. Vol. II, Paris: Hachete, 1986.

.Dicionário de Semiótica. São Paulo: Cultrix, s.d.

GREIMAS, A.J.; FONTANILLE, J. Semiótica das Paixões. São Paulo: Ática, 1993.

GREIMAS, A.J.; RASTIER, F. "O jogo das restrições semióticas”. In: GREIMAS, A.J. Sobre o sentido: ensaios semióticos. Petrópolis: Vozes: 1975.

HEUSSER, Frei Bruno. História Sagrada do Antigo e do Novo Testamento. 65a.ed. Petrópolis: Vozes, 2003.

HJELMSLEV, L. Prolegômenos a uma teoria da linguagem. São Paulo: Perspectiva, 1975. 
HOUAISS, Antônio. Minidicionário Houaiss da língua portuguesa. Rio de Janeiro: Objetiva, 2004.

JACOB, César Romero. et al. Atlas de Filiação Religiosa e Indicadores Sociais no Brasil. São Paulo: Loyola, 2003. de 2004 .

Dossiê Religiões no Brasil. São Paulo: IEA, vol. 18, no. 52, de setembro a dezembro

JADON, José Carlos. A ideologia do sucesso: uma análise semiótica do discurso televisivo da Igreja Universal do Reino de Deus. Dissertação de Mestrado. São Paulo: Universidade Presbiteriana Mackenzie, 2005.

JOÃO PAULO II, Papa. Catecismo da Igreja Católica: Edição Típica Vaticana. São Paulo, Loyola, 2000.

LOPES, Ivã Carlos. Anotações de aula (curso: Semiótica Poética, ministrado no segundo semestre de 2005, na FFLCH/USP).

LOPES, Ivã Carlos; HERNANDES, Nilton (orgs.). Semiótica: objetos e práticas. São Paulo: Contexto, 2005.

LÓTMAN, I.M \& USPENSKII, B.A. Mito, nome e cultura. In: LÓTMAN, I.M; USPENSKII, B.A; IVANÓV, V. (orgs). Ensaios de semiótica soviética. Lisboa: Livros Horizonte, 1981.

MAINGUENEAU, Dominique. Pragmática para o discurso literário. São Paulo: Martins Fontes, 1996.

Novas Tendências em Análise do Discurso. 3ª.ed. Campinas: Pontes, 1997.

.Análise de Textos de Comunicação. 3a . ed. São Paulo: Cortez, 2004.

.A Gênese dos discursos. Curitiba: Criar Edições, 2005a.

.Éthos, cenografia, incorporação. In: Imagens de si no discurso: a construção do éthos. São Paulo: Contexto, 2005b. p. 69-90. 
MARCUSCHI, Luiz Antônio. Gêneros textuais: definição e funcionalidade. In: DIONISIO, A.P; MACHADO, A. R.; BEZERRA, M.A. (orgs) Gêneros Textuais \& Ensino. 2 ${ }^{\mathrm{a}}$. ed. Rio de Janeiro: Lucerna, 2003.

Gêneros Textuais: Configuração, Dinamicidade e Circulação. In: KARWOSKI, A. M; GAYDECZKA, B; BRITO, K. S. (orgs). Gêneros Textuais: Reflexões e Ensino. Paraná: União da Vitória, 2005a.

MARCUSCHI, Luiz Antônio; XAVIER, Antônio Carlos (orgs) Hipertexto e Gêneros Digitais. 2a. ed. Rio de Janeiro: Lucerna, 2005b.

MARQUES, Leonardo Arantes. História das Religiões e a Dialética do Sagrado. São Paulo: Madras, 2005.

MENDES, Mariza Bianconcini Teixeira. Rei Davi: O discurso passional na Bíblia e no cinema. Revista do Gel/Grupo de estudos lingüísticos do Estado de São Paulo. Araraquara, vol. 1, p. 47-57, 2004.

MERLEAU-PONTY, Maurice. Fenomenologia da Percepção. São Paulo, Martins Fontes, 1994.

MEU LIVRO de Histórias Bíblicas. São Paulo: Sociedade Torre de Vigia de Bíblias e Tratados, 1978.

NOSSO Ministério do Reino. São Paulo: Sociedade Torre de Vigia de Bíblias e Tratados, 1999.

NOVA ENCICLOPÉDIA Barsa. São Paulo: Barsa Consultoria Editorial, 2001.

O QUE DEUS requer de nós. São Paulo: Sociedade Torre de Vigia de Bíblias e Tratados, 1996.

ORLANDI, E. A Linguagem e seu funcionamento: As formas do discurso. $4^{\mathrm{a}}$.ed. Campinas : Pontes, 1996.

.Discurso Fundador. $3^{\text {a }}$. ed. Campinas: Pontes, 2003. 
PANIER, Louis. O discurso de interpretação no comentário bíblico. In: GREIMAS \& LANDOWSKI. Análise do discurso em ciências sociais. São Paulo: Global, 1986.

. Une lecture semiotique des textes: questions de theologie biblique. In : Semiotique et Bible. Lyon: Revue trimestrielle publiée sous la direction du Centre pour l' Analyse du Discours Religieux (CADIR), no. 56, dezembro de 1989.

PERELMAN, C.; OLBRECHTS-TYTECA. Tratado de Argumentação: A nova retórica. São Paulo: Martins Fontes, 2005.

PIETROFORTE, Antônio Vicente. Discurso da tradição esotérica religiosa: uma abordagem semiótica. Dissertação de Mestrado. São Paulo: Universidade de São Paulo, 1997.

Semiótica visual: os percursos do olhar. São Paulo: Contexto, 2004a.

. Uma imagem da música. Análise semiótica de uma capa de disco. CASA: Cadernos de Semiótica aplicada, vol.2, n.2, dezembro de 2004b.

Anotações de aula (curso: Os Sistemas Semi-Simbólicos. Tópicos de

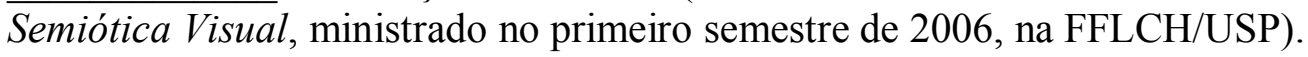

PLATÃO \& FIORIN. Lições de texto: leitura e redação. São Paulo: Ática, 2004.

PRANDI, Reginaldo. O Brasil com axé: candomblé e umbanda no mercado religioso. In: JACOB, César Romero. et. al. Dossiê Religiões no Brasil. São Paulo: IEA, vol. 18, no. 52, de setembro a dezembro de 2004. p. 223-238.

RABAÇA, Carlos Alberto; BARBOSA; Gustavo Guimarães. Dicionário de Comunicação. São Paulo: Ática, 1987.

RACIOCINIOS à base das Escrituras. São Paulo: Sociedade Torre de Vigia de Bíblias e Tratados, 1989.

RAMOS-SILVA, Sueli Maria. A reafirmação da fé no antigo relato da criação: Uma abordagem semiótica do discurso católico. Revista Estudos Semióticos 2/ Grupo de Estudos Semióticos FFLCH-USP (GES-USP). São Paulo: v.2, n. 2, 2006. Disponível em: www.fflch.usp.br/d1/semiotica/es. Acesso em julho 2007. Acesso em: novembro 2006. 
. Análise de textos de "divulgação religiosa": o éthos dado como confronto de paixões. Revista Estudos Semióticos 3/ Grupo de Estudos Semióticos FFLCH-USP (GES-USP). São Paulo: v.3, n. 3, 2007. Disponível em: www.fflch.usp.br/dl/semiotica/es. Acesso em: julho 2007.

SANTIDRIÁN, Pedro R. Dicionário básico das religiões. Aparecida - SP: Editora Santuário, 1996.

SAUSSURE, Ferdinand de. Curso de Lingüistica Geral. São Paulo: Cultrix, 2004.

SCHWIKART, Georg. Dicionário Ilustrado das Religiões. Aparecida, SP: Editora Santuário, 2001.

SENTINELA: Anunciando o Reino de Jeová. São Paulo: Sociedade Torre de Vigia de Bíblias e Tratados, 1997.

SEVERINO, Antonio Joaquim. Metodologia do Trabalho Científico. 22a .ed. São Paulo: Cortez, 2002.

SURIAN, Frei Carmelo. Primeiro Catecismo da Doutrina Cristã. $145^{\mathrm{a}}$. ed. Petrópolis: Vozes, 2005.

TATIT, Luiz. Musicando a Semiótica: Ensaios. São Paulo: Annablume, 1997.

. Semiótica da canção: melodia e letra. $2^{\mathrm{a}}$.ed. São Paulo: Escuta, 1999.

. Análise Semiótica através das Letras. São Paulo: Ateliê Editorial, 2001.

. “Abordagem do texto". In: José Luiz Fiorin (org). Introdução à Lingüística I: Objetos teóricos. 2a . ed. São Paulo: Contexto, 2003, p. 187-209.

.Tensões da dor. In: Fernandes, Rinaldo de (Org.). Textos sobre as canções, o teatro e a ficção de um artista brasileiro. Rio de Janeiro: Fundação Biblioteca Nacional; Garamond, 2004a, p.305-312.

Anotações de aula (curso: Semiótica: Teoria e Aplicação na canção Brasileira), ministrado no segundo semestre de 2005, na FFLCH/USP). 
TEIXEIRA, Lúcia. Copo, gaveta, memória e sentido: análise semiótica da função da crônica nos cadernos de cultura dos jornais cariocas. In: CANIZAL, E. \& CAETANO, K. O olhar a deriva: mídia, significação e cultura. São Paulo: Annablume, 2004.

.Entre dispersão e acúmulo: para uma metodologia de análise de textos sincréticos.

Gragoatá - Revista do Instituto de Letras da UFF, Niterói, v. 16, p. 209-227, 2004.

Para uma leitura de textos visuais. cópia xerografada.

TESTEMUNHAS DE JEOVÁ - Quem são? Em que crêem? São Paulo: Sociedade Torre de Vigia de Bíblias e Tratados, 2000.

TOLSTÓI, S.M. Para uma semântica dos lados esquerdo e direito nas relações com outros elementos simbólicos. In: LÓTMAN, I.M; USPENSKII, B.A; IVANÓV, V. (orgs). Ensaios de semiótica soviética. Lisboa: Livros Horizonte, 1981. p.227-230.

TRADUÇÃO do Novo Mundo das Escrituras Sagradas. São Paulo: Sociedade Torre de Vigia de Bíblias e Tratados, 1992.

WATCHTOWER Library 2001. Versão em Português. São Paulo: Sociedade Torre de Vigia de Bíblias e Tratados, 2002. 1 CD-ROM.

WÖLFFLIN, Heinrich. Renascença e Barroco. São Paulo: Perspectiva, 1989.

. Conceitos Fundamentais da História da Arte. São Paulo: Martins Fontes,

2000.

ZILBERBERG, Claude. L 'essor du poéme: information rythmique. Saint-Maur: Phoriques, s.d.

1988.

Raison et poétique du sens. Paris : Presses Universitaires de France,

. Relativite du rythme.Théories e pratiques sémiotiques. Proteé. Vol. 18, n.1., 1990.

.Présence de Wölfflin. Nouveaux Actes Sémiotiques 23-24. Pulim, Université de Limoges, 1992. 

1996.

.Signification du rythme et ritytme de la signification. In: DEGRÉS n. 87. Bruxelles, . Razão e poética do sentido. São Paulo: Editora da Universidade de São Paulo, 2006. 
ANEXOS 
ANEXO A - Capítulo II - Ilustrações do corpus de divulgação religiosa: enunciatário infanto-juvenil (Totalidade A - Catolicismo)

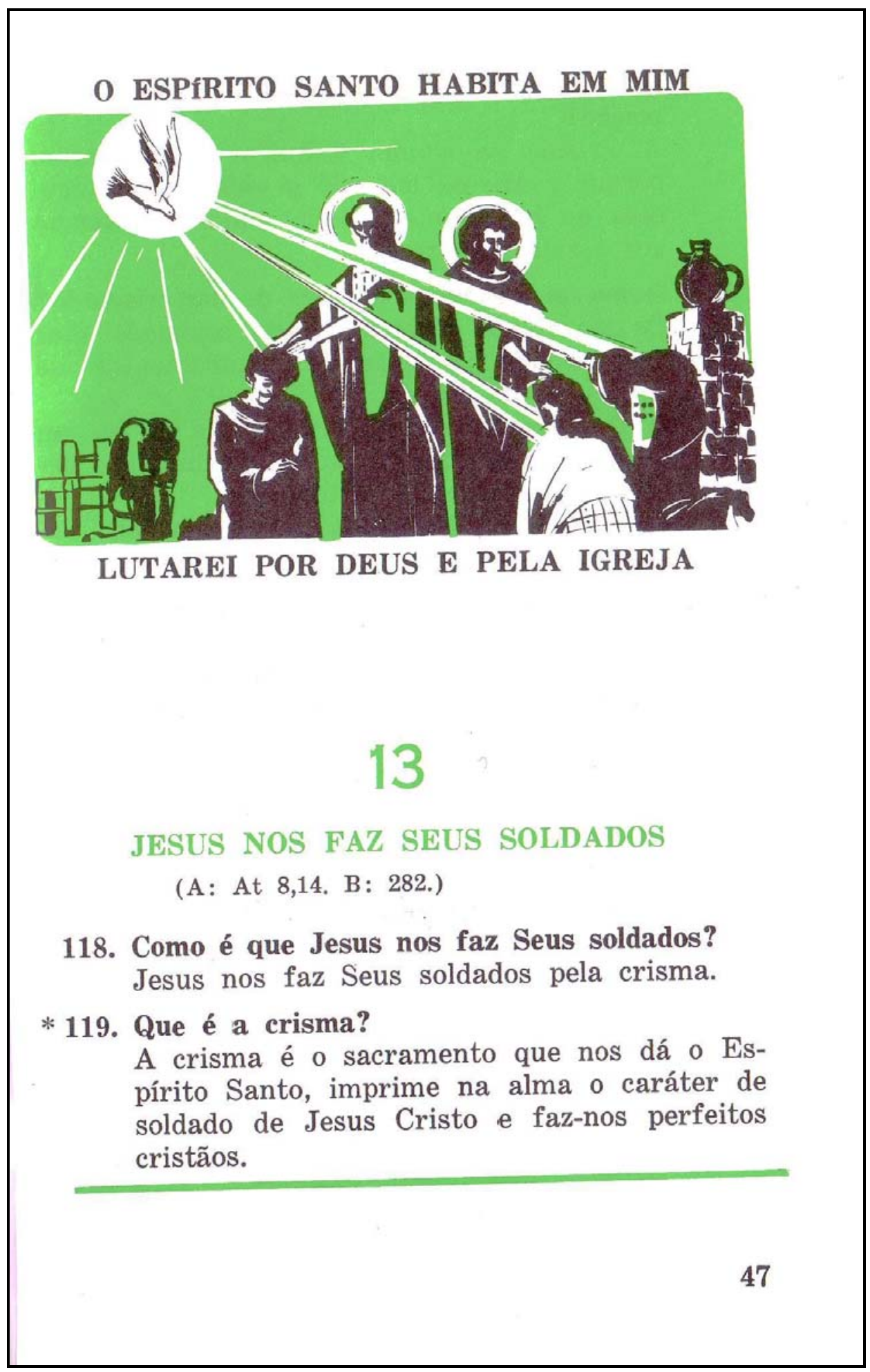

Ilustração 53 SURIAN, Frei Carmelo. Primeiro catecismo da Doutrina Cristã. 145 ed. São Paulo: Vozes, 2005. p. 47. 
* 120. Por que a crisma se chama também confirmação?

A crisma se chama também confirmação, porque confirma em nós a vida divina recebida no batismo e nos dá maior resistência aos assaltos da tentação.

* 121. Quais os principais deveres de um crismado? Os principais deveres de um crismado são: 1. Guardar fielmente os mandamentos de Deus e da Igreja.

$2^{\circ}$ Defender corajosamente a vida divina em seu coração dos perigos do mundo, do demônio e das más inclinações.

3. Amar a Santa Igreja e trabalhar por ela, sem respeito humano, como bom apóstolo.

122. Como devem preparar-se os que recebem a crisma em idade adulta?

Os que recebem a crisma em idade adulta devem preparar-se estudando bem a doutrina católica e fazendo uma boa confissão.

\section{NA LITURGIA}

Marcando-nos com a unção da cruz na testa, a crisma nos torna propriedade sagrada do Senhor. Por isso, em todas as cantas missas de que participamos, juntamente com o ofertório da hóstia e do vinho, devemos renovar a oferta de nós mesmos ao serviço do Senhor e da Sua Santa Igreja.

\section{ORAÇÃO}

Ó Espírito Santo, vinde habitar em meu coração e tornaime um templo vivo, onde brilhe a Vossa glória. Amém.

MISSÃO A CUMPRIR

Indagar entre parentes e amigos sobre quem ainda não

Ilustração 54. SURIAN, Frei Carmelo. Primeiro catecismo da Doutrina Cristã. 145 ed. São Paulo: Vozes, 2005. p. $47-48$. 
foi crismado e procurar levá-los à crisma.

DEVO GUARDAR PARA A VIDA

Sou templo vivo do Espírito Santo.

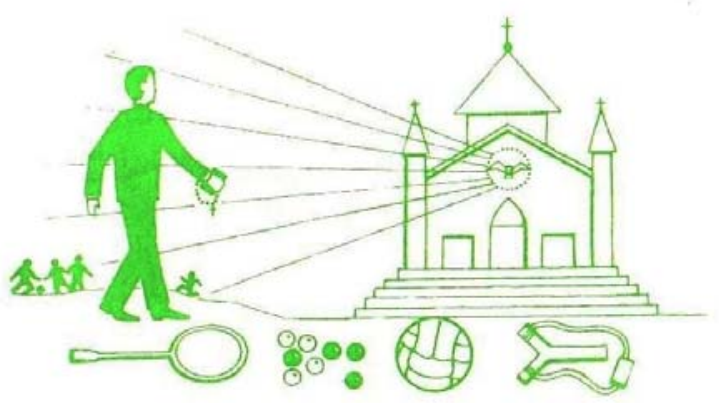

Ele foi crismado. Com a força do Espírito Santo, vence as tentações e não deixa de cumprir seus deveres de católico.

Ilustração 55 SURIAN, Frei Carmelo. Primeiro catecismo da Doutrina Cristã. 145 ed. São Paulo: Vozes, 2005. p. 49. 


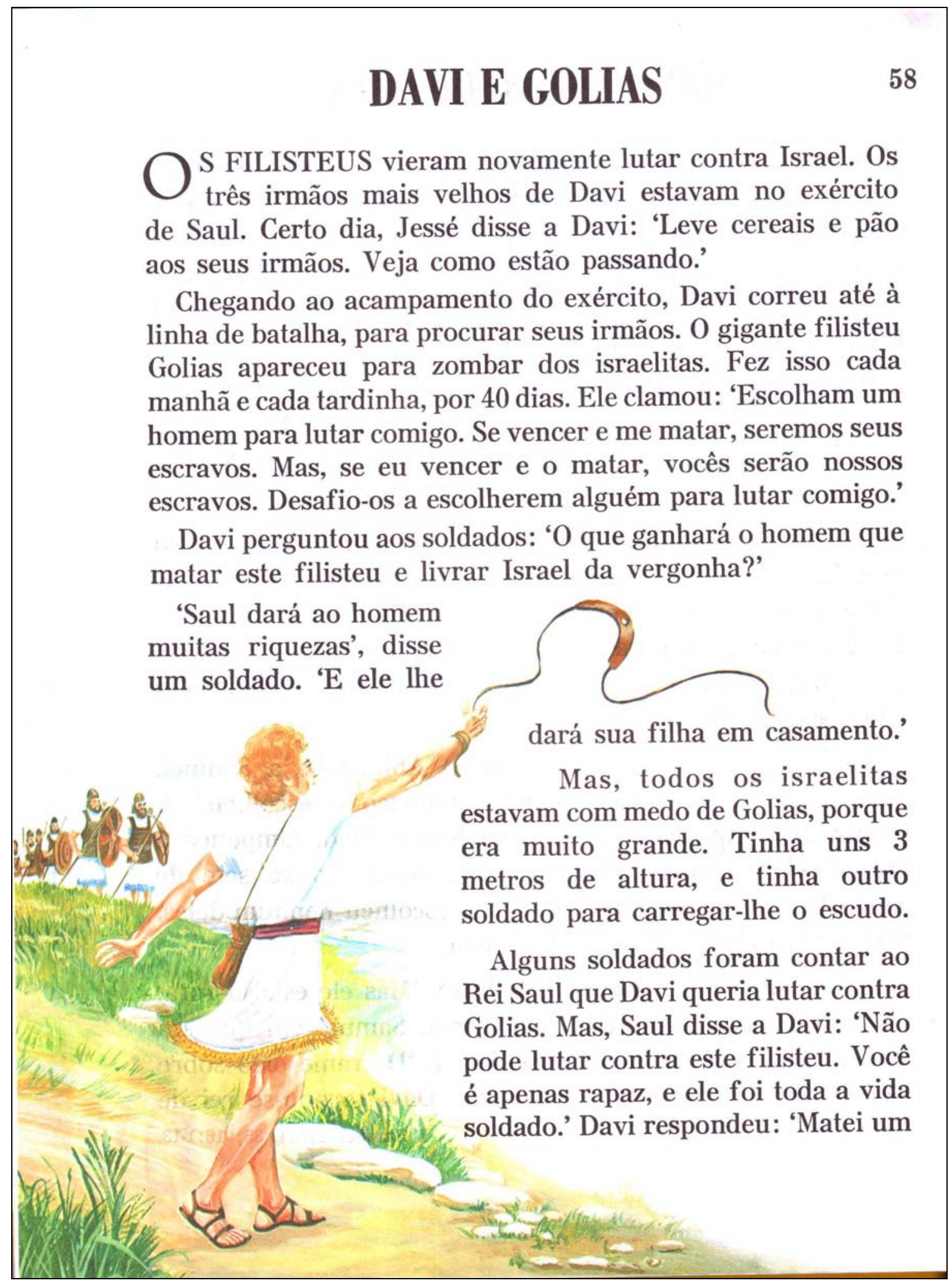

Ilustração 56 MEU LIVRO de Histórias Bíblicas. São Paulo: Sociedade Torre de Vigia de Bíblias e Tratados, 1978. História 58. 
urso e um leão que haviam levado ovelhas de meu pai. E este filisteus será como um deles. Jeová me ajudará.' Saul disse então: 'Vá, e Jeová esteja com você.'

Davi desceu a um riacho para apanhar cinco pedras lisas, que pôs na sua bolsa. Depois tomou a funda e foi ao encontro do gigante. Vendo-o Golias, quase não acreditou. Achou que era fácil matar Davi.

'Venha para cá', disse Golias, 'e eu vou dar seu cadáver às aves e aos animais'. Mas, Davi disse: 'Você vem a mim com espada, lança e dardo, mas eu o enfrento no nome de Jeová. Hoje, Jeová entregará você na minha mão e eu o abaterei.'

Então, Davi correu para Golias. Tirou uma pedra da bolsa, colocou-a na funda e atirou-a com toda a força. A pedra atingiu Golias bem na cabeça, e ele caiu morto! Vendo os filisteus que seu campeão havia caído, todos fugiram. Os israelitas correram atrás deles e venceram a batalha.

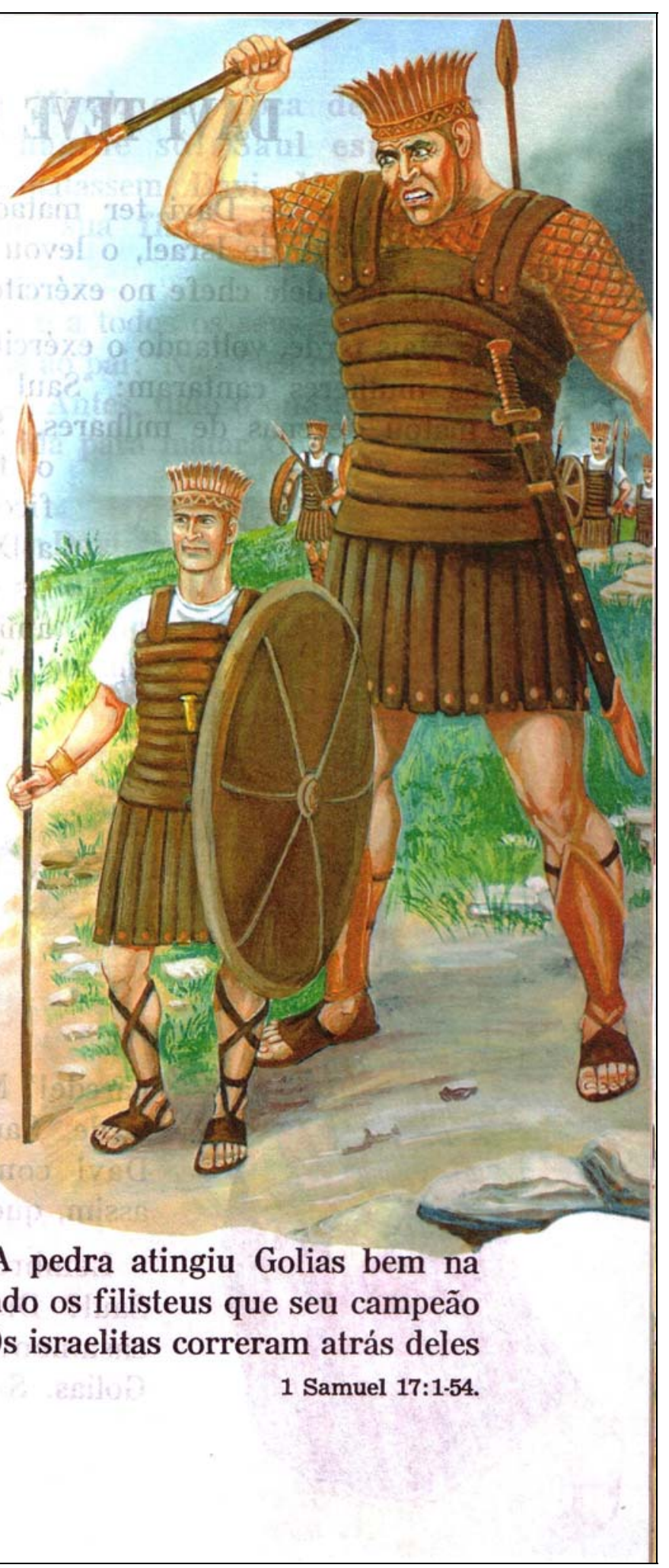

Ilustração 57 MEU LIVRO de Histórias Bíblicas. São Paulo: Sociedade Torre de Vigia de Bíblias e Tratados, 1978. História 58. 
ANEXO C - Capítulo III - Ilustrações do corpus de divulgação religiosa: enunciatário

\section{adulto (Totalidade $\mathrm{A}$ - Catolicismo)}

BENTO XVI. Segunda Seção: Os sete Sacramentos da Igreja: In: Compêndio do Catecismo da Igreja Católica. São Paulo: Loyola, 2005.p.87-111.

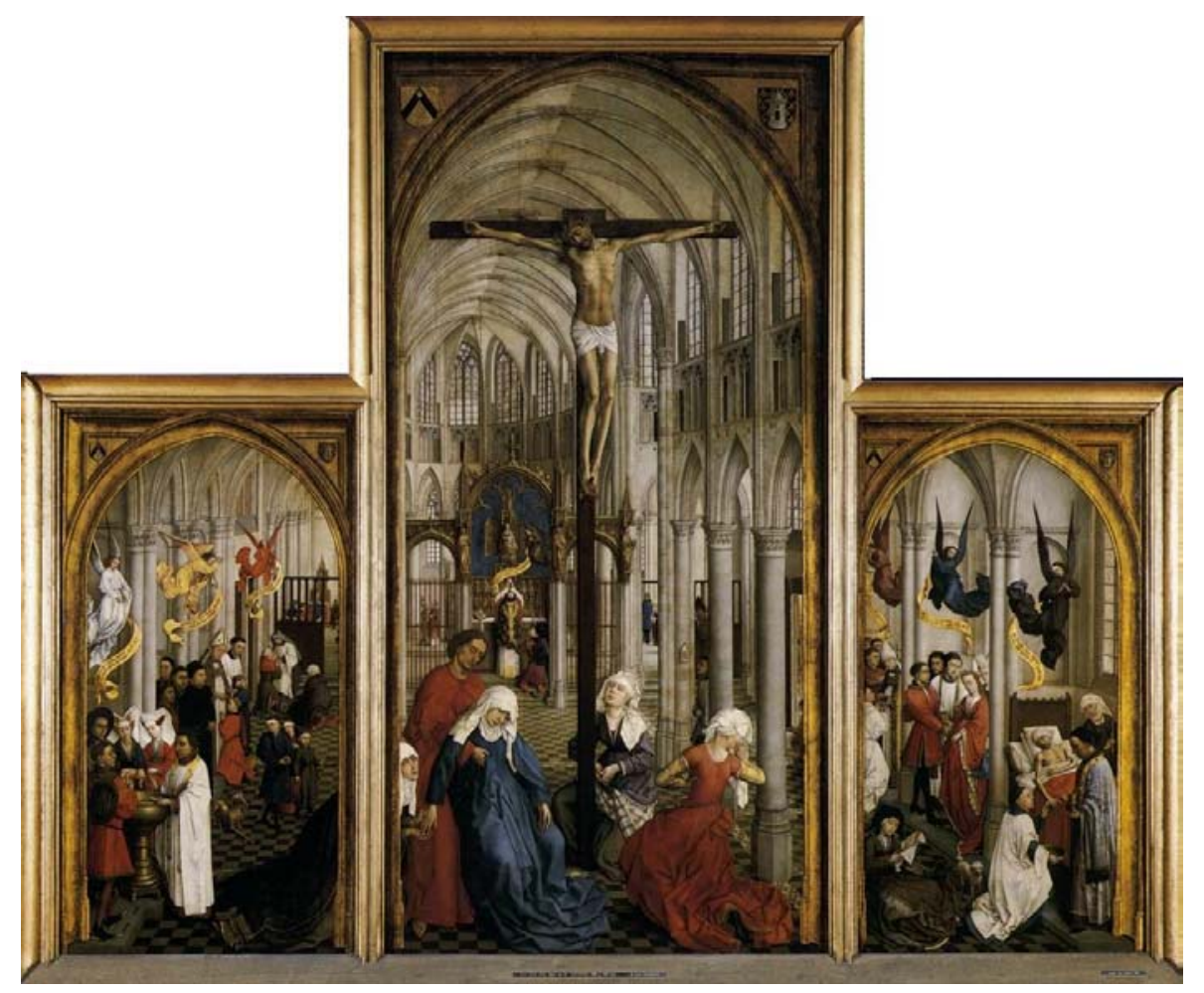

ROGIER VAN DER WEYDEN, Tríptico dos sete sacramentos, Koninklijk Museum voor Schone Kunsten, Antuérpia

Os sete sacramentos da Igreja

Batismo

Confirmação

Eucaristia

Penitência

Unção dos enfermos

Ordem

Matrimônio

\section{Septem Ecclesiae Sacramenta}

Baptismum

Confirmatio

Eucharistia

Paenitentia

Unctio infirmorum

Ordo

Matrimonium 
Os sacramentos da Igreja são o fruto do sacrifício redentor de Jesus na Cruz. O tríptico representa uma igreja na qual são celebrados os sete sacramentos. No centro se ergue, predominante, a cruz. Aos pés do crucifixo, estão Maria desfalecida, sustentada por João, e as mulheres devotas. No fundo um sacerdote celebrante eleva a hóstia depois da consagração, para indicar que o sacrifício da cruz é novamente atualizado na celebração eucarística sob as espécies do pão e do vinho.

No retábulo da esquerda, que mostra uma capela lateral, são representados os sacramentos do batismo, do crisma, ministrado pelo bispo, e da penitência. No da direita são representados os sacramentos da ordem, também ministrado pelo bispo, do matrimônio e da unção dos enfermos.

\section{Como se distinguem os sacramentos da Igreja?}

Distinguem-se em: sacramentos da iniciação cristã (Batismo, Confirmação e Eucaristia); sacramentos da cura (Penitência e Unção dos enfermos); sacramentos a serviço da comunhão e da missão (Ordem e Matrimônio). Eles tocam os momentos importantes da vida cristã. Todos os sacramentos estão ordenados à Eucaristia "como a seu fim específico" (Santo Tomás de Aquino). 1210-1211

\section{CAPÍTULO PRIMEIRO}

\section{Os sacramentos da iniciação cristã}

251. Como se realiza a iniciação cristã?

Ela se realiza mediante os sacramentos que estabelecem os fundamentos da vida cristã: os fiéis, renascidos no Batismo, são fortalecidos pela Confirmação e são nutridos pela Eucaristia. 12121275

\section{O SACRAMENTO DO BATISMO}

\section{Que nomes recebe o primeiro sacramento da iniciação?}

Recebe em primeiro lugar o nome de Batismo por causa do rito central com o qual é celebrado: batizar significa "imergir" na água. Quem é batizado é imerso na morte de Cristo e ressurge com ele como "criatura nova" (2Cor 5,17). É chamado também de "banho da regeneração e renovação do Espírito Santo" (Tt 3,5) e de "iluminação" porque o batizado se torna "filho da luz" (Ef 5,8-9). 1213-1216 1276-1277

\section{Como é prefigurado o Batismo na Antiga Aliança?}

$\mathrm{Na}$ Antiga Aliança encontram-se várias prefigurações do Batismo: a água, fonte de vida e de morte; a arca de Noé, que salva por meio da água; a passagem do Mar Vermelho, que liberta Israel da escravidão egípcia; a travessia do Jordão, que introduz Israel na terra prometida, imagem da vida eterna. $1217-1222$

\section{Quem dá acabamento a essas prefigurações?}

Jesus Cristo, o qual, no início da sua vida pública, se faz batizar por João Batista no Jordão; na cruz, do seu lado traspassado brotam sangue e água, sinais do Batismo e da Eucaristia, e depois da sua Ressurreição confia aos Apóstolos esta missão: "Ide, pois, fazer discípulos entre todas as nações, e batizai-os em nome do Pai, do Filho e do Espírito Santo" (Mt 28,19). 1223-1224

\section{Desde quando e a quem a Igreja administra o Batismo?}

Desde o dia de Pentecostes a Igreja administra o Batismo a quem crê em Jesus Cristo. 1226-1228

\section{Em que consiste o rito essencial do Batismo?}

$\mathrm{O}$ rito essencial desse sacramento consiste em imergir na água o candidato ou em derramar água sobre sua cabeça, enquanto é invocado o Nome do Pai, do Filho e do Espírito Santo. 1229-1245 1278 


\section{Quem pode receber o Batismo?}

Qualquer pessoa ainda não batizada pode receber o Batismo. 1246-1252

258. Por que a Igreja batiza as crianças?

Porque elas, tendo nascido com o pecado original, precisam ser libertadas do poder do Maligno e ser transferidas para o reino da liberdade dos filhos de Deus. 1250

\section{O que se requer de um batizando?}

De todo batizando se requer a profissão de fé, expressa pessoalmente, no caso do adulto, ou pelos pais e pela Igreja, no caso da criança. Também o padrinho ou a madrinha e toda a comunidade eclesial têm uma parte de responsabilidade na preparação para o Batismo (catecumenato), bem como no desenvolvimento da fé e da graça batismal. 1253-1255

\section{Quem pode batizar?}

Os ministros ordinários do Batismo são o bispo e o presbítero; na Igreja latina, também o diácono. Em caso de necessidade, qualquer um pode batizar, desde que tenha intenção de fazer o que faz a Igreja. Derrama água sobre a cabeça do candidato e pronuncia a fórmula trinitária batismal: "Eu te batizo em Nome do Pai, do Filho e do Espírito Santo". 12561284

\section{O Batismo é necessário para a salvação?}

O Batismo é necessário à salvação para aqueles aos quais foi anunciado o Evangelho e que têm a possibilidade de pedir esse sacramento. 1257

\section{Pode-se ser salvo sem o Batismo?}

Uma vez que Cristo morreu pela salvação de todos, podem ser salvos mesmo sem Batismo todos os que morrem por causa da fé (Batismo de sangue), os catecúmenos, e também todos aqueles que sob o impulso da graça, sem conhecer Cristo e a Igreja, procuram sinceramente Deus e se esforçam por cumprir a sua vontade (Batismo de desejo). Quanto às crianças mortas sem Batismo, a Igreja na sua liturgia as confia à misericórdia de Deus. 1258-1261 1281-1283

\section{Quais são os efeitos do Batismo?}

O Batismo perdoa o pecado original, todos os pecados pessoais e as penas devidas ao pecado; faz participar da vida divina trinitária mediante a graça santificante, a graça da justificação que incorpora a Cristo e à sua Igreja; faz participar do sacerdócio de Cristo e constitui o fundamento da comunhão com todos os cristãos; propicia as virtudes teologais e os dons do Espírito Santo. 0 batizado pertence para sempre a Cristo: é marcado, com efeito, com o selo indelével de Cristo (caráter). 1262-1274 $1279-1280$

\section{Que significado assume o nome cristão recebido no Batismo?}

O nome é importante, porque Deus conhece cada qual pelo nome, ou seja, na sua unicidade. Com o Batismo, o cristão recebe na Igreja o próprio nome, preferivelmente o de um Santo, de modo que este ofereça ao batizado um modelo de santidade e lhe garanta a sua intercessão junto a Deus. 2156-2159 2167

\section{O SACRAMENTO DA CONFIRMAÇÃO}

\section{Qual é o lugar da Confirmação no desígnio divino da salvação?}

$\mathrm{Na}$ Antiga Aliança, os profetas anunciaram a comunicação do Espírito do Senhor ao Messias esperado e a todo o povo messiânico. Toda a vida e a missão de Jesus se desenvolvem numa total comunhão com o Espírito Santo. Os Apóstolos recebem o Espírito Santo no Pentecostes e anunciam "as maravilhas de Deus" (At 2,11). Comunicam aos neobatizados, mediante a imposição das mãos, o dom do mesmo Espírito. Ao longo dos séculos, a Igreja continuou a viver do Espírito e a comunicá-lo aos seus filhos. 1285-1288 1315 
266. Por que se chama Crisma ou Confirmação?

Chama-se Crisma (nas Igrejas Orientais: Crismação com o Santo Myron), por causa do seu rito essencial, que é a unção. Chama-se Confirmação, porque confirma e consolida a graça batismal. 1289

\section{Qual é o rito essencial da Confirmação?}

O rito essencial da Confirmação é a unção com o sagrado crisma (óleo misturado com bálsamo, consagrado pelo bispo), que se faz com a imposição da mão por parte do ministro que pronuncia as palavras sacramentais próprias do rito. No Ocidente, essa unção é feita na fronte do batizado com as palavras: "Recebe por este sinal o dom do Espírito Santo". Nas Igrejas Orientais de rito bizantino, a unção e feita também em outras partes do corpo, com a fórmula: "Selo do dom que é o Espírito Santo". 1290-1301 1318 1320-1321

\section{Qual é o efeito da Confirmação?}

$\mathrm{O}$ efeito da Confirmação é a especial efusão do Espírito Santo, como a de Pentecostes. Essa efusão imprime na alma um caráter indelével e produz um crescimento da graça batismal: enraíza mais profundamente na filiação divina; une mais solidamente a Cristo e a sua Igreja; aumenta na alma os dons do Espírito Santo; dá força especial para testemunhar a fé cristã. 1302-1305 1316-1317

\section{Quem pode receber esse sacramento?}

Pode e deve recebê-lo, uma única vez, quem já foi batizado, o qual, para recebê-lo eficazmente, deve estar em estado de graça. 1306-1311 1319

\section{Quem é o ministro da Confirmação?}

O ministro originário é o bispo. Manifesta-se assim a ligação do crismado com a Igreja na sua dimensão apostólica. Quando é o presbítero que confere esse sacramento - como acontece ordinariamente no Oriente e em casos particulares no Ocidente -, a ligação com o bispo e com a Igreja é expressa pelo presbítero, colaborador do bispo, e pelo sagrado crisma, consagrado pelo próprio bispo. 1312-1314

\section{O SACRAMENTO DA EUCARISTIA}

\section{O que é a Eucaristia?}

É o próprio sacrifício do Corpo e do Sangue do Senhor Jesus, que ele instituiu para perpetuar pelos séculos, até seu retorno, o sacrifício da cruz, confiando assim à sua Igreja o memorial de sua Morte e Ressurreição. É o sinal da unidade, o vínculo da caridade, o banquete pascal, no qual se recebe Cristo, a alma é coberta de graça e é dado o penhor da vida eterna. 1322-1323 1409

\section{Quando Jesus Cristo instituiu a Eucaristia?}

Institui-a na Quinta-feira Santa, "na noite em que ia ser entregue" (1 Cor 11,23), celebrando com os seus Apóstolos a Última Ceia. 1323 1337-1340

\section{Como a instituiu?}

Depois de ter reunido os seus Apóstolos no Cenáculo, Jesus tomou nas suas mãos o pão, partiu-o e o deu a eles, dizendo: "Tomai todos e comei: isto é o meu corpo que será entregue por vós". Depois tomou nas suas mãos o cálice do vinho e lhes disse: "Tomai todos e bebei: este é o cálice do meu sangue, o sangue da nova e eterna aliança, que será derramado por vós e por todos para remissão dos pecados. Fazei isto em memória de mim". 1337-1340 1365,1406

\section{O que representa a Eucaristia na vida da Igreja?}

É fonte e ápice de toda a vida cristã. Na Eucaristia, atingem o seu clímax a ação santificante de Deus para conosco e o nosso culto para com ele. Ela encerra todo o bem espiritual da Igreja: o mesmo Cristo, nossa Páscoa. A comunhão da vida divina e a unidade do Povo de Deus são expressas e realizadas pela Eucaristia. Mediante a celebração eucarística, já nos unimos à liturgia do Céu e antecipamos a vida eterna. 1324-1327 1407 


\section{Como é chamado esse sacramento?}

A insondável riqueza desse sacramento se exprime com diversos nomes que evocam seus aspectos particulares. Os mais comuns são: Eucaristia, Santa Missa, Ceia do Senhor, Fração do pão, Celebração eucarística, Memorial da paixão, da morte e da ressurreição do Senhor, Santo Sacrifício, Santa e Divina Liturgia, Santos Mistérios, Santíssimo Sacramento do altar, Santa Comunhão. 1328-1332

\section{Como se situa a Eucaristia no desígnio divino da salvação?}

$\mathrm{Na}$ Antiga Aliança, a Eucaristia é prenunciada, sobretudo, na ceia pascal anual, celebrada todo ano pelos hebreus com os pães ázimos como lembrança da imprevista e libertadora saída do Egito. Jesus a anuncia em seu ensinamento e a institui celebrando com os seus Apóstolos a última Ceia durante um banquete pascal. A Igreja, fiel ao mandamento do Senhor, "Fazei isto em minha memória" (1 Cor 11,24), sempre celebrou a Eucaristia, sobretudo no domingo, dia da ressurreição de Jesus. 1333-1344

\section{Como se desdobra a celebração da Eucaristia?}

Desdobra-se em dois grandes momentos, que formam um só ato de culto: a liturgia da Palavra, que compreende a proclamação e a escuta da Palavra de Deus; a liturgia eucarística, que compreende a apresentação do pão e do vinho, a oração ou anáfora, que contém as palavras da consagração, e a comunhão. 1345-1355 1408

\section{Quem é o ministro da celebração da Eucaristia?}

É o sacerdote (bispo ou presbítero), validamente ordenado, que age na Pessoa de Cristo Cabeça e em nome da igreja. 13481411

\section{Quais são os elementos essenciais e necessários para realizar a Eucaristia?}

São o pão de trigo e o vinho da videira. 1412

\section{Em que sentido a Eucaristia é memorial do sacrifício de Cristo?}

A Eucaristia é memorial no sentido de que torna presente e atual o sacrifício que Cristo ofereceu ao Pai na cruz, uma vez por todas, em favor da humanidade. 0 caráter sacrifical da Eucaristia se manifesta nas próprias palavras da instituição: "Isto é o meu corpo, que é dado por vós" e "Este cálice é a nova aliança no meu sangue, que é derramado por vós" (Lc 22,19-20). 0 sacrifício da cruz e o sacrifício da Eucaristia são um único sacrifício. Idênticos são a vítima e o oferente, diferente é apenas o modo de oferecer: cruento na cruz, incruento na Eucaristia. 1362-1367

\section{De que modo a Igreja participa do sacrifício eucarístico?}

$\mathrm{Na}$ Eucaristia, o sacrifício de Cristo se torna também o sacrifício dos membros do seu Corpo. A vida dos fiéis, seu louvor, seu sofrimento, sua oração, seu trabalho estão unidos ao de Cristo. Como sacrifício, a Eucaristia é também oferecida por todos os fiéis vivos e defuntos, em reparação dos pecados de todos os homens e para obter de Deus benefícios espirituais e temporais. Também a Igreja do céu está unida na oferta de Cristo. 1368-1372 1414

\section{Como Jesus está presente na Eucaristia?}

Jesus Cristo está presente na Eucaristia de modo único e incomparável. Está presente, com efeito, de modo verdadeiro, real, substancial:com o seu Corpo e o seu Sangue, com a sua Alma e a sua Divindade. Nela está, portanto, presente de modo sacramental, ou seja, sob as espécies eucarísticas do pão e do vinho, Cristo todo inteiro: Deus e homem. 1373-1375 1413

\section{0 que significa transubstanciação?}

Transubstanciação significa a conversão de toda a substância do pão na substância do Corpo de Cristo e de toda a substância do vinho na substância do seu Sangue. Essa conversão se realiza na oração eucarística, mediante a eficácia da palavra de Cristo e da ação do Espírito Santo. Todavia, as características sensíveis do pão e do vinho, ou seja, as "espécies eucarísticas", permanecem inalteradas. 1376-1377 1413 


\section{A fração do pão divide Cristo?}

A fração do pão não divide Cristo: ele está presente todo e íntegro em cada espécie eucarística e em cada uma de suas partes. 1377

\section{Até quando continua a presença eucarística de Cristo?}

Ela continua até que subsistam as espécies eucarísticas. 1377

\section{Que tipo de culto é devido ao sacramento da Eucaristia?}

É devido o culto de latria, ou seja, de adoração reservado unicamente a Deus, seja durante a celebração eucarística, seja fora dela. A Igreja, com efeito, conserva com a máxima diligência as Hóstias consagradas, leva-as aos enfermos e a outras pessoas impossibilitadas de participar da Santa Missa, apresenta-as à solene adoração dos fiéis, leva-as em procissão e convida à freqüente visita e adoração do Santíssimo Sacramento conservado no tabernáculo. 1378-1381 1418

\section{Por que a Eucaristia é o banquete pascal?}

A Eucaristia é o banquete pascal, porquanto Cristo, ao realizar sacramentalmente a sua Páscoa, nos dá o seu Corpo e o seu Sangue, oferecidos como alimento e bebida, e nos une a si e entre nós no seu sacrifício.1382-1384 1391-1396

288. O que significa o altar?

O altar é o símbolo do próprio Cristo, presente como vítima sacrifical (altar-sacrifício da cruz) e como alimento celeste que se dá a nós (altarmesa eucarística). 13831410

\section{Quando a Igreja obriga a participar da santa missa?}

A Igreja obriga os fiéis a participar da santa missa todo domingo e nas festas de preceito, e recomenda que dela se participe também nos outros dias. 13891417

\section{Quando se deve comungar?}

A Igreja recomenda aos fiéis que participam da santa missa que recebam com as devidas disposições também a santa Comunhão, prescrevendo a obrigação de comungar pelo menos na Páscoa. 1389

\section{O que se requer para receber a santa comunhão?}

Para receber a santa Comunhão, deve-se estar plenamente incorporado à Igreja católica e estar em estado de graça, ou seja, sem consciência de pecado mortal. Quem estiver consciente de ter cometido um pecado grave deve receber o sacramento da Reconciliação antes de se aproximar da comunhão. Importantes são também o espírito de recolhimento e de oração, a observância do jejum prescrito pela Igreja e a atitude do corpo (gestos, roupas), em sinal de respeito a Cristo. 1385-1389 1415

\section{Quais são os frutos da santa Comunhão?}

A santa comunhão aumenta a nossa união com Cristo e com a sua Igreja, conserva e renova a vida de graça recebida no Batismo e na Crisma e nos faz crescer no amor para com o próximo. Fortificandonos na caridade, cancela os pecados veniais e nos preserva de futuros pecados mortais. 1391-1397 1416

293. Quando é possível administrar a santa Comunhão aos outros cristãos?

Os ministros católicos administram licitamente a santa Comunhão aos membros das Igrejas Orientais que não têm comunhão plena com a Igreja católica sempre que eles o pedirem espontaneamente e estiverem bem dispostos.

Para os membros de outras comunidades eclesiais, os ministros católicos administram licitamente a santa Comunhão aos fiéis que diante de uma grave necessidade o peçam espontaneamente, estejam bem dispostos e manifestem a fé católica a respeito do sacramento. 1398-1401 


\section{Por que a Eucaristia é "penhor da glória futura"?}

Porque a Eucaristia nos enche de graça e bênção do Céu, fortalecenos para a peregrinação nesta vida e nos faz desejar a vida eterna, unindo-nos já a Cristo, que subiu para a direita do Pai, à Igreja do céu, à beatíssima Virgem e a todos os Santos. 1402-1405

Na Eucaristia nós partimos "o único pão que é remédio de imortalidade, antídoto para não morrer, mas para viver em Jesus Cristo para sempre” (Santo Inácio de Antioquia).

\section{CAPITULO SEGUNDO}

Os sacramentos de cura

\section{Por que Cristo instituiu os sacramentos da Penitência e da Unção dos enfermos?}

Cristo, médico da alma e do corpo, os instituiu porque a vida nova, que nos foi dada por ele nos sacramentos da iniciação cristã, pode ser enfraquecida e até perdida por causa do pecado. Por isso, Cristo quis que a Igreja continuasse a sua obra de cura e de salvação mediante esses dois sacramentos. $1420-14211426$

\section{O SACRAMENTO DA PENITÊNCIA E DA RECONCILIAÇÃO}

296. Como é chamado esse sacramento?

É chamado de sacramento da Penitência, da Reconciliação, do Perdão, da Confissão, da Conversão. $1422-1424$

\section{Por que existe um sacramento da Reconciliação após o Batismo?}

Uma vez que a vida nova na graça, recebida no Batismo, não suprimiu a fraqueza da natureza humana nem a inclinação ao pecado (ou seja, a concupiscência), Cristo instituiu esse sacramento para a conversão dos batizados que se afastaram dele peso pecado. 1425-1426 1484

\section{Quando foi instituído esse sacramento?}

O Senhor ressuscitado instituiu esse sacramento quando, na noite de Páscoa, apareceu a seus Apóstolos e lhes disse: "Recebei o Espírito Santo. A quem perdoardes os pecados, serão perdoados; a quem os retiverdes, serão retidos" (Jo 20,22-23). 1485

\section{Os batizados têm necessidade de se converter?}

$\mathrm{O}$ apelo de Cristo à conversão ressoa continuamente na vida dos batizados. Essa conversão é um compromisso contínuo para toda a Igreja, que é santa, mas reúne em seu seio os pecadores. 1427-1429

\section{O que é a penitência interior?}

É o dinamismo do "coração contrito" (SI 51,19) movido pesa graça divina a responder ao amor misericordioso de Deus. Implica a dor e a repulsa pesos pecados cometidos, o firme propósito de não mais pecar no futuro e a confiança na ajuda de Deus. Nutre-se da esperança na misericórdia divina. $1430-14331490$

\section{De que formas se exprime a penitência na vida cristã?}

A penitência se exprime de formas muito variadas, em particular com o jejum, a oração, a esmola. Essas e muitas outras formas de penitência podem ser praticadas na vida cotidiano do cristão, em particular no tempo da Quaresma e no dia penitencias da sexta-feira. 1434-1439

\section{Quais são os elementos essenciais do sacramento da Reconciliação?}

São dois: os atos realizados peso homem que se converte sob a ação do Espírito Santo e a absolvição do sacerdote, que no Nome de Cristo concede o perdão e estabelece a modalidade da satisfação. 14401449 


\section{Quais são os atos do penitente?}

São: um diligente exame de consciência; a contrição (ou arrependimento), que é perfeita quando é motivada peso amor para com Deus,imperfeita se fundada em outros motivos, e que inclui o propósito de não pecar mais; a confissão, que consiste na acusação dos pecados feita perante o sacerdote; a satisfação, ou seja, o cumprimento de certos atos de penitência que o confessor impõe ao penitente para reparar o dano causado pelo pecado. 1450-1460 1487-1492

\section{Quais pecados se devem confessar?}

Devem-se confessar todos os pecados graves ainda não confessados de que alguém se lembra depois de um diligente exame de consciência. A confissão dos pecados graves é o único modo ordinário para obter o perdão. 1456

\section{Quando há obrigação de confessar os pecados graves?}

Todo fiel, tendo atingido a idade da razão, é obrigado a confessar os próprios pecados graves pelo menos uma vez ao ano, e sempre antes de receber a santa Comunhão. 1457

\section{Por que os pecados veniais podem ser também objeto da confissão sacramental?}

Embora não seja estritamente necessária, a confissão dos pecados veniais é vivamente recomendada pela Igreja, porque nos ajuda a formar uma reta consciência e a lutar contra as tendências más, para nos deixar curar por Cristo e progredir na vida do Espírito. 1458

\section{Quem é o ministro desse sacramento?}

Cristo confiou o ministério da reconciliação a seus Apóstolos, aos bispos seus sucessores e aos presbíteros seus colaboradores, os quais se tornam, portanto, instrumentos da misericórdia e da justiça de Deus. Eles exercem o poder de perdoar os pecados em Nome do Pai, do Filho e do Espírito Santo. 1461-1466 1495

\section{A quem está reservada a absolvição de alguns pecados?}

A absolvição de alguns pecados particularmente graves (como os punidos com a excomunhão) está reservada à Sé Apostólica ou ao bispo do lugar ou aos presbíteros por eles autorizados, embora qualquer sacerdote possa absolver de qualquer pecado e excomunhão quem estiver em perigo de morte. 1463

\section{O confessor deve guardar segredo?}

Dada a delicadeza e a grandiosidade desse ministério e o respeito devido às pessoas, todo confessor é obrigado, sem exceção alguma e sob penas muito severas, a guardar o sigilo sacramental, ou seja, o absoluto segredo acerca dos pecados conhecidos na confissão. 1467

\section{Quais são os efeitos desse sacramento?}

Os efeitos do sacramento da Penitência são: a reconciliação com Deus e, portanto, o perdão dos pecados; a reconciliação com a Igreja; a recuperação do estado de graça, se foi perdido; a remissão da pena eterna merecida por causa dos pecados mortais e, pelo menos em parte, das penas temporais que são conseqüência do pecado; a paz e a serenidade da consciência, e a consolação do espírito; o crescimento das forças espirituais para o combate cristão. 1468-1470 1496

311. Em alguns casos, pode-se celebrar esse sacramento com a confissão genérica e a absolvição coletiva?

Em casos de grave necessidade (como em perigo iminente de morte), pode-se recorrer à celebração comunitária da Reconciliação com a confissão genérica e a absolvição coletiva, no respeito das normas da Igreja e com o propósito de confessar individualmente no devido tempo os pecados graves. 1480-1484 
312. O que são as indulgências?

As indulgências são a remissão diante de Deus da pena temporal merecida pelos pecados, já perdoados quanto à culpa, que o fiel, em determinadas condições, adquire para si mesmo ou para os defuntos mediante o ministério da Igreja, a qual, como dispensadora da redenção, distribui o tesouro dos méritos de Cristo e dos Santos. 1471-1479 1498

\section{O SACRAMENTO DA UNÇÃO DOS ENFERMOS}

\section{Como é vivida a doença no Antigo Testamento?}

No Antigo Testamento, o homem experimenta durante a doença o próprio limite e percebe ao mesmo tempo que a doença está ligada, de modo misterioso, ao pecado. Os profetas entreviram que ela podia ter também um valor redentor para os pecados próprios e dos outros. Assim, a doença era vivida diante de Deus, a quem o homem implorava a cura. 1499-1502

\section{Que significado tem a compaixão de Jesus para com os doentes?}

A compaixão de Jesus para com os doentes e as suas numerosas curas de enfermos são um claro sinal de que com ele chegou o Reino de Deus e, portanto, a vitória sobre o pecado, sobre o sofrimento e sobre a morte. Com sua paixão e morte, ele dá novo sentido ao sofrimento, o qual, se unido ao seu, pode se tornar meio de purificação e de salvação para nós e para os outros. 1503-150

\section{Qual é o comportamento da Igreja em relação aos doentes?}

A Igreja, tendo recebido do Senhor a ordem de curar os enfermos compromete-se a cumpri-la com os cuidados para com os doentes, acompanhados de oração de intercessão. Ela possui sobretudo um sacramento específico em favor dos enfermos, instituído pelo próprio Cristo e atestado por são Tiago: "Alguém dentre vós está doente?[/b] Mande chamar os presbíteros da igreja, para que orem sobre ele, ungido-o com óleo no nome do Senhor" (Tg 5,14). 1506-1513 1526-1527

\section{Quem pode receber o sacramento da Unção dos enfermos?}

Pode recebê-lo o fiel que começa a se encontrar em perigo de morte poi doença ou velhice. O mesmo fiel pode recebê-lo também outras vezes, quando se verifica um agravamento da doença ou quando lhe acontece uma outra doença grave. A celebração desse sacramento deve ser, se possível precedida pela confissão individual do doente. 1514-1515 1528-1525

\section{Quem administra esse sacramento?}

Ele pode ser administrado somente pelos sacerdotes (bispos ou presbíteros). 15161530

\section{Como se celebra esse sacramento?}

A celebração desse sacramento consiste essencialmente na unção com o óleo, bento possivelmente pelo bispo, sobre a fronte e sobre w mãos do doente (no rito romano, ou também em outras parte do corpo em outros ritos), acompanhada pela oração do sacerdote, que implora a graça especial desse sacramento. 1517-1519 1531

\section{Quais são os efeitos desse sacramento?}

Ele confere uma graça particular, que une mais intimamente o doente à Paixão de Cristo, para o seu bem e o de toda a Igreja, dando-lhe conforto, paz, coragem e até o perdão dos pecados, se o doente não pôde confessar-se. Esse sacramento permite às vezes, se Deus o quiser, até a recuperação da saúde física. Em todo caso, essa Unção prepara o doente para a passagem à Casa do Pai. 1520-1523 1532

\section{O que é o Viático?}

É a Eucaristia recebida por aqueles que estão por deixar esta vida terrena e se preparam para a passagem para a vida eterna. Recebida no momento da passagem deste mundo para o Pai, a comunhão do Corpo e do Sangue de Cristo morto e ressuscitado é semente de vida eterna e poder de ressurreição. $1524-1525$ 


\section{CAPITULO TERCEIRO}

\section{Os sacramentos a serviço da comunhão e da missão}

321. Quais são os sacramentos a serviço da comunhão e da missão?

Dois sacramentos, a Ordem e o Matrimônio, conferem uma graça especial para uma missão particular na Igreja a serviço da edificação do povo de Deus. Eles contribuem em particular para a comunhão eclesial e para a salvação dos outros. 1533-1535

\section{O SACRAMENTO DA ORDEM}

322. O que é o sacramento da Ordem?

É o sacramento graças ao qual a missão confiada por Cristo aos seus Apóstolos continua a ser exercida na Igreja, até o final dos tempos. 1536

\section{Por que se chama sacramento da Ordem?}

Ordem indica um corpo eclesial de que se passa a fazer parte mediante uma especial consagração (Ordenação), a qual, por um particular dom do Espírito Santo, permite exercer um sagrado poder em nome e com a autoridade de Cristo a serviço do Povo de Deus. 1537-1538

\section{Como se situa o sacramento da Ordem no desígnio divino da salvação?}

$\mathrm{Na}$ Antiga Aliança, são prefigurações desse sacramento o serviço dos Levitas, bem como o sacerdócio de Aarão e a instituição dos setenta "Anciãos" (Nm 11,25). Essas prefigurações encontram seu cumprimento, em Cristo Jesus, o qual, com o sacrifício da sua cruz, é o "único [...] mediador entre Deus e os homens" (1Tm 2,5), o "sumo Sacerdote à maneira de Melquisedec" (Hb 5,10). 0 único sacerdócio de Cristo se torna presente pelo sacerdócio ministerial. 1539-1546 1590-1591

"Somente Cristo é o verdadeiro sacerdote; os outros são os seus ministros" (Santo Tomás de Aquino).

325. De quantos graus se compõe o sacramento da Ordem?

Compõe-se de três graus, que são insubstituíveis para a estrutura orgânica da Igreja: o episcopado, o presbiterado e o diaconato. 15541593

\section{Qual é o efeito da Ordenação episcopal?}

A Ordenação episcopal confere a plenitude do sacramento da Ordem, faz do bispo o legítimo sucessor dos Apóstolos, insere-o no Colégio episcopal, partilhando com o papa e os outros bispos a solicitude por todas as Igrejas, e lhe confia os ofícios de ensinar, santificar e reger. 1557-1558 1594

\section{Qual é o ofício do bispo na Igreja particular a ele confiada?}

O bispo, a quem é confiada a Igreja particular, é o princípio visível e o fundamento da unidade dessa Igreja, em relação à qual exerce, como vigário de Cristo, o oficio pastoral, ajudado pelos próprios presbíteros e diáconos. 1560-1561

\section{Qual é o efeito da Ordenação presbiteral?}

A unção do Espírito marca o presbítero comum com um caráter espiritual indelével, configura-o a Cristo sacerdote e o torna capaz de agir no Nome de Cristo Cabeça. Sendo cooperador da Ordem episcopal, ele é consagrado para pregar o Evangelho, para celebrar o culto divino, sobretudo a Eucaristia de que tira força o seu ministério, e para ser o pastor dos fiéis. 1562-1567 1595

\section{Como o presbítero exerce o próprio ministério?}

Mesmo sendo ordenado para uma missão universal, ele a exerce numa Igreja particular, em fraternidade sacramental com os outros presbíteros que formam o "presbitério" e que, em comunhão com o bispo e em dependência dele, têm a responsabilidade da Igreja particular. 1568 


\section{Qual é o efeito da Ordenação diaconal?}

0 diácono, configurado a Cristo servo de todos, é ordenado para o serviço da Igreja, que ele exerce sob a autoridade do próprio bispo, a respeito do ministério da Palavra, do culto divino, da orientação pastoral e da caridade. 1569-1571 1596

\section{Como se celebra o sacramento da Ordem?}

Para cada um dos três graus, o sacramento da Ordem é conferido mediante a imposição das mãos sobre a cabeça do ordenando por parte do bispo, que pronuncia a solene oração consagradora. Com ela o Bispo invoca de Deus para o ordenando a especial efusão do Espírito Santo e dos seus dons, em vista do ministério. 1572-1574 1597

\section{Quem pode conferir esse sacramento?}

Cabe aos bispos validamente ordenados, como sucessores dos Apóstolos, conferir os três graus do sacramento da Ordem. 1575-1576 1600

\section{Quem pode receber esse sacramento?}

Pode recebê-lo validamente apenas o batizado de sexo masculino: a Igreja se reconhece ligada a essa escolha feita pelo próprio Senhor. Ninguém pode exigir receber o sacramento da Ordem, mas deve ser considerado apto ao ministério pela autoridade da Igreja. 1577-1578 1598

\section{Exige-se o celibato de quem recebe o sacramento da Ordem?}

Para o episcopado é sempre exigido o celibato. Para o presbiterado, na Igreja latina, ordinariamente escolhem-se homens crentes, que vivem como celibatários e que têm intenção de manter-se no celibato "pelo reino dos céus" (Mt 19,12); nas Igrejas Orientais não é permitido casar-se depois de ter recebido a ordenação. Ao diaconato permanente podem ter acesso também homens já casados. 157915801599

\section{Quais são os efeitos do sacramento da Ordem?}

Esse sacramento dá uma especial efusão do Espírito Santo, que configura o ordenado a Cristo na sua tríplice função de Sacerdote, Profeta e Rei, segundo os respectivos graus do sacramento. A ordenação confere um caráter espiritual indelével: por isso não pode ser repetida nem conferida por um tempo limitado. 1581-1589

\section{Com que autoridade é exercido o sacerdócio ministerial?}

Os sacerdotes ordenados, no exercício do ministério sagrado, falam e agem não por autoridade própria nem por mandato ou por delegação da comunidade, mas na Pessoa de Cristo Cabeça e em nome da Igreja. Portanto, o sacerdócio ministerial se diferencia essencialmente e não apenas por grau do sacerdócio comum dos fiéis, a serviço do qual Cristo o instituiu. 1547-1553 1592

\section{O SACRAMENTO DO MATRIMÔNIO}

\section{Qual é o desígnio de Deus sobre o homem e sobre a mulher?}

Deus, que é amor e criou o homem por amor, chamou-o a amar. Criando o homem e a mulher, chamou-os no Matrimônio a uma íntima comunhão de vida e de amor entre si, "assim, eles não são mais dois, mas uma só carne" (Mt 19,6). Ao abençoá-los, Deus lhes disse: "Sede fecundos e prolíficos" (Gn 1,28). 1601-1605

\section{Para que fins Deus instituiu o Matrimônio?}

A união matrimonial do homem e da mulher, fundada e estruturada com leis próprias pelo Criador, por sua natureza está ordenada à comunhão e ao bem dos cônjuges e à geração e educação dos filhos. A união matrimonial, segundo o originário desígnio divino, é indissolúvel, como afirma Jesus Cristo: "Não separe, pois, o homem o que Deus uniu" (Mc 10,9). 1659-1660 
339. De que modo o pecado ameaça o Matrimônio?

Por causa do primeiro pecado, que provocou também a ruptura da comunhão dada pelo Criador entre o homem e a mulher, a união matrimonial é muitas vezes ameaçada pela discórdia e pela infidelidade. Todavia, Deus, na sua infinita misericórdia, dá ao homem e à mulher a sua graça para realizar a união das suas vidas segundo o originário desígnio divino.1606-1608

\section{O que ensina o Antigo Testamento sobre o Matrimônio?}

Deus, sobretudo por meio da pedagogia da Lei e dos profetas, ajuda seu povo a amadurecer progressivamente a consciência da unicidade da indissolubilidade do Matrimônio. A aliança nupcial de Deus com Israel prepara e prefigura a Aliança nova realizada pelo Filho de Deus, Jesus Cristo, com a sua esposa, a Igreja. 1609-1611

\section{Qual é a novidade dada por Cristo ao Matrimônio?}

Jesus Cristo não só restabelece a ordem inicial querida por Deus, mas dá a graça para viver o Matrimônio na nova dignidade de sacramento, que é o sinal do seu amor esponsal pela Igreja: "Maridos, amai as vossas mulheres como Cristo amou a Igreja" (Ef 5,25). 1612-1617 1661

\section{O Matrimônio é uma obrigação para todos?}

O Matrimônio não é uma obrigação para todos. Em particular Deus chama alguns homens e mulheres a seguir o Senhor Jesus na via da virgindade e do celibato pelo Reino dos céus, renunciando ao grande bem do Matrimônio para se preocupar com as coisas do Senhor e procurar agradar-Lhe, tornando-se sinal da absoluta primazia do amor de Cristo e da ardente expectativa da sua vinda gloriosa. 16181620

\section{Como se celebra o sacramento do Matrimônio?}

Uma vez que o Matrimônio estabelece os cônjuges num estado público de vida na Igreja, a sua celebração litúrgica é pública, na presença do sacerdote (ou da testemunha qualificada pela Igreja) e das outras testemunhas. 1621-1624

\section{O que é o consenso matrimonial?}

O consenso matrimonial é a vontade expressa por um homem e por uma mulher de se doar mutuamente e definitivamente, com o objetivo de viver uma aliança de amor fiel e fecundo. Uma vez que o consentimento faz o Matrimônio, ele é indispensável e insubstituível. Para tornar válido Matrimônio, o consenso deve ter como objeto o verdadeiro Matrimônio ser um ato humano, consciente e livre, não determinado por violência ou constrangimentos. 1625-1632 1662-1663

\section{O que se exige quando um dos esposos não é católico?}

Para serem lícitos, os matrimônios mistos (entre católico e batizado não-católico) exigem a licença da autoridade eclesiástica. Os que têm disparidade de culto (entre católico e não-batizado) para serem válidos têm necessidade de uma dispensa. Em todo caso, é essencial que os cônjuges não excluam a aceitação dos fins e das propriedades essenciais do Matrimônio, e que o cônjuge católico confirme os compromissos, conhecidos também pelo outro cônjuge, de manter a fé e de garantir o Batismo a educação católica dos filhos. 1633-1637

\section{Quais são os efeitos do sacramento do Matrimônio?}

O sacramento do Matrimônio gera entre os cônjuges um vínculo perpétuo e exclusivo. 0 próprio Deus sela o consenso dos esposos. Portanto, o Matrimônio concluído e consumado entre batizados jamais pode ser dissolvido. Além disso, esse sacramento confere aos esposos a graça necessária para atingir a santidade na vida conjugal e para o acolhimento responsável dos filhos e a educação deles. 1638-1642

\section{Quais são os pecados gravemente contrários ao sacramento do Matrimônio?}

São: o adultério; a poligamia, porquanto contradiz a igual dignidade entre o homem e a mulher, a unicidade e a exclusividade do amor conjugal; a rejeição da fecundidade, que priva a vida conjugal do dom dos filhos; o divórcio, que transgride a indissolubilidade. 1645-1648 
348. Quando a Igreja admite a separação física dos esposos?

A Igreja admite a separação física dos esposos quando a coabitação deles se tornou, por motivos graves, praticamente impossível, embora deseje muito uma reconciliação deles. Mas eles, enquanto vive o cônjuge, não estão livres para contrair uma nova união, a menos que seu Matrimônio seja nulo e como tal seja declarado pela autoridade eclesiástica. 16291649

\section{Qual é a atitude da Igreja em relação aos divorciados recasados?}

Fiel ao Senhor, a Igreja não pode reconhecer como Matrimônio a união dos divorciados recasados civilmente. "Se alguém repudia sua mulher se casa com outra, é adúltero com respeito à primeira; e se a mulher repudia seu marido e se casa com outro, ela é adúltera" (Mc 10,11-12). Para com eles a Igreja tem uma atenta solicitude, convidando-os a uma vida de fé, à oração, às obras de caridade e à educação cristã dos filhos. Mas eles não podem receber a absolvição sacramental nem se aproximar da comunhão eucarística nem exercer certas responsabilidades eclesiais enquanto perdura essa situação, que objetivamente contraria a lei de Deus. 1650-1651 1665

\section{Por que a família cristã é chamada também de Igreja doméstica?}

Porque a família manifesta e realiza a natureza de comunhão e familiar da Igreja como família de Deus. Cada membro, segundo o próprio papel, exerce o sacerdócio batismal, contribuindo para fazer da família uma comunidade de graça e de oração, escola das virtudes humanas e cristãs, lugar do primeiro anúncio da fé aos filhos. 1655-1658 1666

\section{CAPITULO QUARTO}

\section{As outras celebrações litúrgicas}

\section{OS SACRAMENTAIS}

\section{O que são os sacramentais?}

São sinais sagrados instituídos pela Igreja por meio dos quais se santificam algumas circunstâncias da vida. Compõem-se de uma oração acompanhada pelo sinal-da-cruz e por outros sinais. Entre os sacramentais ocupam um lugar importante as bênçãos, que são um louvor de Deus e uma oração para obter os seus dons, as consagrações das pessoas e as dedicações de coisas ao culto de Deus. 1667-1672 $1677-1678$

\section{O que é um exorcismo?}

Tem-se um exorcismo quando a Igreja pede com a sua autoridade, em nome de Jesus, que uma pessoa ou um objeto seja protegido contra a influência do Maligno e subtraído a seu domínio. É praticado de forma ordinária no rito do Batismo. 0 exorcismo solene, chamado o grande exorcismo, pode ser efetuado somente por um presbítero autorizado pelo bispo. 1673

\section{Que formas de piedade popular acompanham a vida sacramental da Igreja?}

O sentido religioso do povo cristão encontrou sempre diversas expressões nas várias formas de piedade que acompanham a vida sacramental da Igreja, como a veneração das relíquias, as visitas aos santuários, as peregrinações, as procissões, a via-sacra, o rosário. A Igreja com a luz da fé ilumina e favorece as formas autênticas de piedade popular. 1674-1676 1679

\section{OS FUNERAIS CRISTÃOS}

\section{Que relação existe entre os sacramentos e a morte do cristão?}

$\mathrm{O}$ cristão que morre em Cristo chega, no término da sua existência terrena, ao cumprimento da nova vida iniciada com o Batismo, fortalecida pela Confirmação e nutrida pela Eucaristia, antecipação do banquete celeste. O sentido da morte do cristão manifesta-se à luz da Morte e da Ressurreição de 
Cristo, nossa única esperança; o cristão que morre em Cristo Jesus vai "morar junto do Senhor" (2Cor 5,8). 1680-1683

\section{O que exprimem os funerais?}

Os funerais, embora celebrados segundo diferentes ritos correspondentes às situações e às tradições de cada região, exprimem o caráter pascal da morte cristã na esperança da ressurreição, e o sentido da comunhão com o defunto particularmente mediante a oração e a purificação da sua alma. 1684-1685

\section{Quais são os momentos principais dos funerais?}

Habitualmente os funerais compreendem quatro momentos principais: o acolhimento do corpo por parte da comunidade com palavras de conforto e de esperança, a liturgia da Palavra, o sacrifício eucarístico e "o adeus", com o qual a alma do defunto é confiada a Deus, fonte de vida eterna, enquanto o seu corpo é sepultado à espera da ressurreição. 1686-1690 


\section{ANEXO D- Capítulo III - Ilustrações do corpus de divulgação religiosa: enunciatário}

adulto (Totalidade $\mathbf{B}-\mathbf{T J}$ )

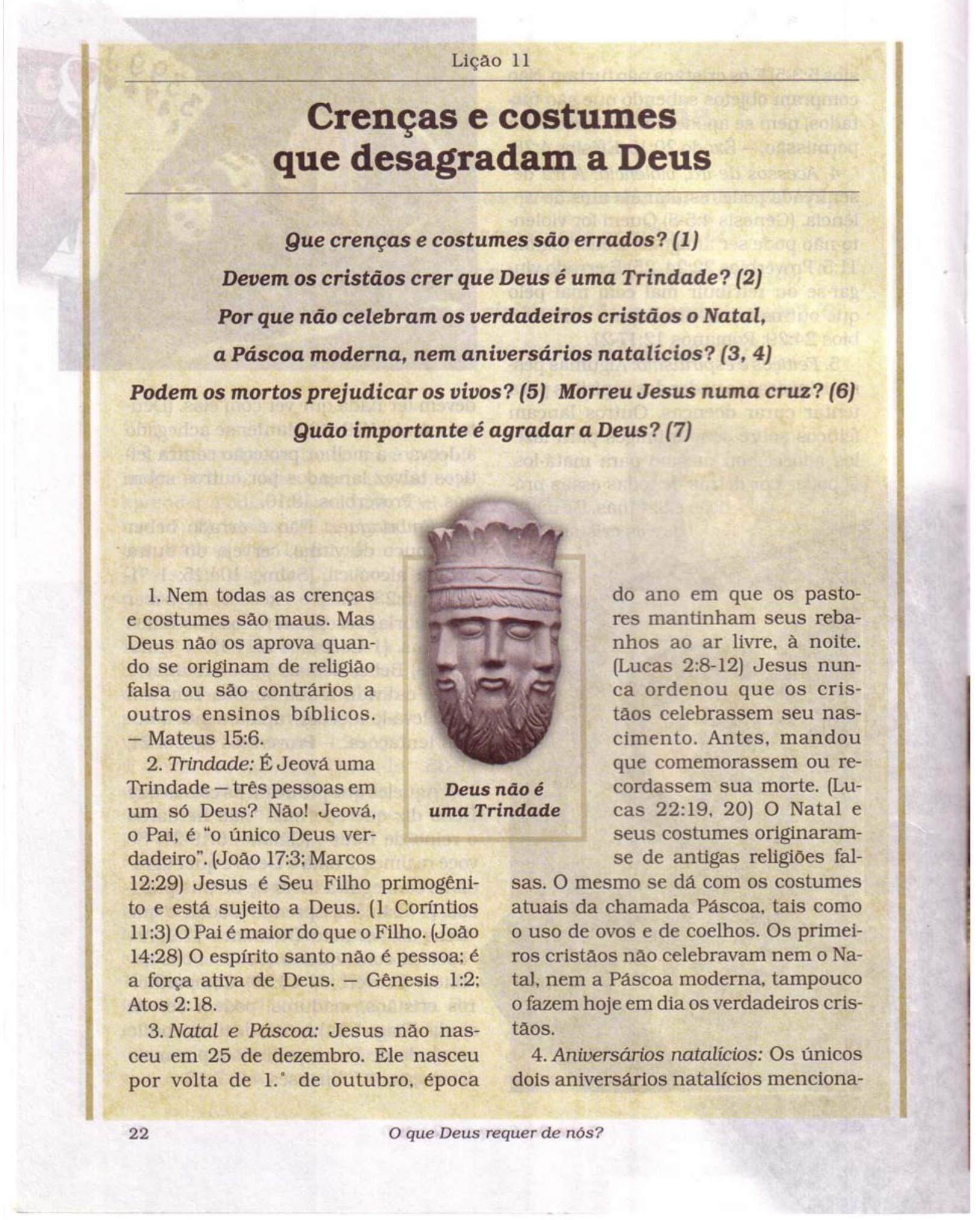

Ilustração 58 O QUE DEUS requer de nós? São Paulo: Sociedade Torre de Vigia de Bíblias e Tratados, 1996. p. 22. 
dos na Bíblia eram de pessoas que não adoravam a Jeová. (Gênesis 40:20-22; Marcos 6:21, 22, 24-27) Os primeiros cristãos não celebravam aniversários natalícios. O costume de celebrar natalícios originou-se das antigas religiões falsas. Os cristãos verdadeiros dão presentes e se divertem juntos em outras ocasiōes do ano.

5. Medo dos mortos: Os mortos nâo podem fazer nem sentir nada. Não podemos ajudá-los, nem podem eles prejudicar-nos. (Salmo 146:4; Eclesiastes $9: 5,10)$ A alma morre; não continua viva após a morte. (Ezequiel 18:4) Mas às vezes anjos iníquos, chamados demônios, fingem ser espíritos de mortos. Os costumes que têm que ver com o medo ou a adoração dos mortos são errados. - Isaías 8:19.

6. A cruz: Jesus não morreu numa cruz. Ele morreu num poste, ou estaca. A palavra grega, em muitas Bíblias traduzida "cruz", refere-se apenas a um
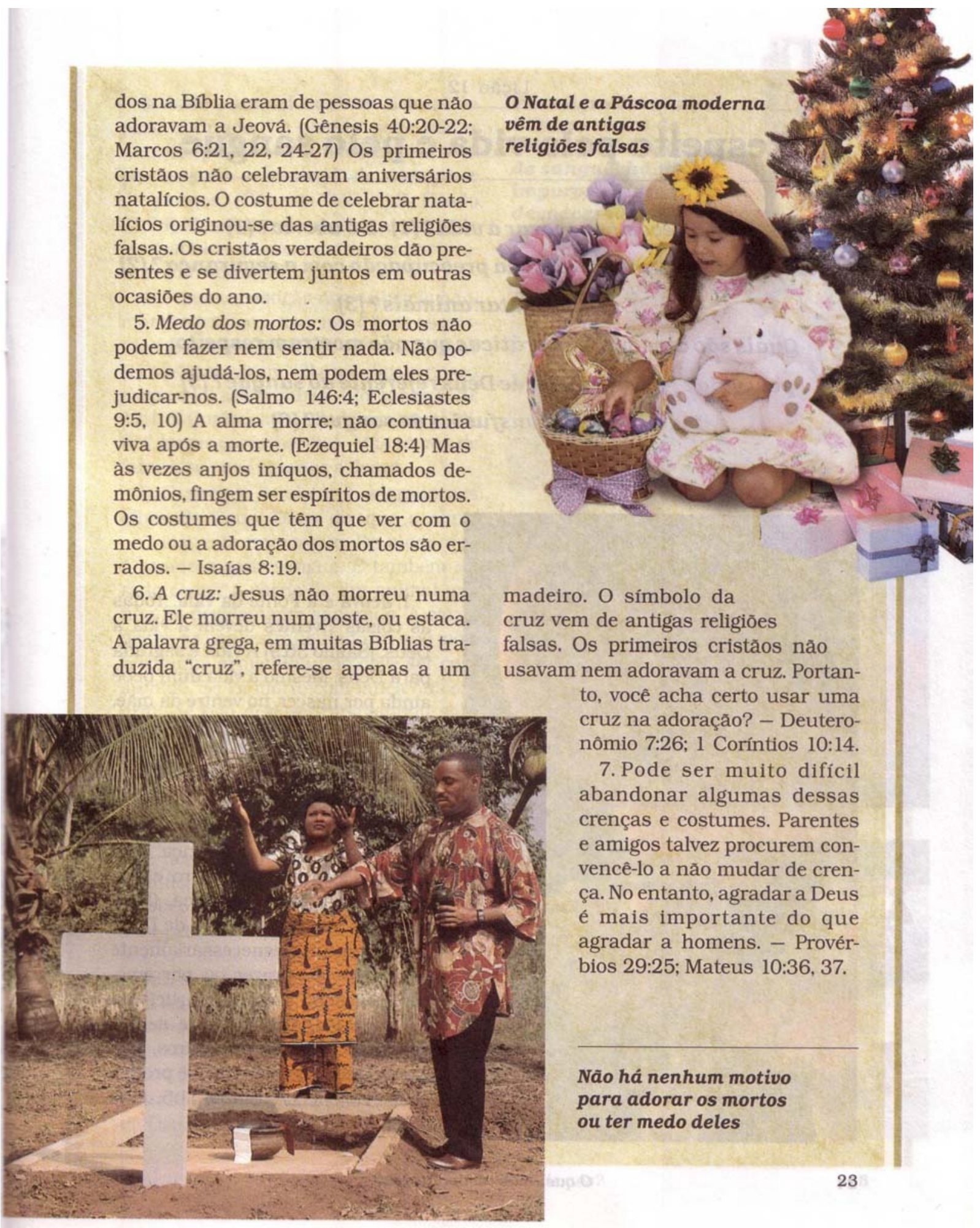
cruz na adoração? - Deutero7:26: 1 Coríntios 10:14. ça. No entanto, agradar a Deus é mais importante do que agradar a homens. - Provérbios 29:25; Mateus 10:36, 37.

Não há nenhum motivo para adorar os mortos ou ter medo deles

Ilustração 59 O QUE DEUS requer de nós? São Paulo: Sociedade Torre de Vigia de Bíblias e Tratados, 1996.p. p.23. 